Valquíria Aparecida Passos Kneipp

\title{
TRAJETÓRIA DA FORMAÇÃO DO TELEJORNALISTA \\ BRASILEIRO - as implicações do modelo americano
}

Tese apresentada ao Programa de Pós-Graduação em Comunicação, Área de Concentração II Estudo dos Meios e da Produção Midiática, Linha de Pesquisa Comunicação Impressa e Audiovisual, da Escola de Comunicações e Artes da Universidade de São Paulo, como exigência parcial para obtenção do Título de Doutora em Comunicação, sob a orientação do Prof. Dr. José Marques de Melo.

São Paulo 2008 


\title{
UNIVERSIDADE DE SÃO PAULO \\ ESCOLA DE COMUNICAÇÕES E ARTES
}

\section{TRAJETÓRIA DA FORMAÇÃO DO TELEJORNALISTA \\ BRASILEIRO - as implicações do modelo americano}

\author{
Valquíria Passos Kneipp
}

Tese apresentada ao Programa de Pós-Graduação em Comunicação, Área de Concentração II Estudo dos Meios e da Produção Midiática, Linha de Pesquisa Comunicação Impressa e Audiovisual, da Escola de Comunicações e Artes da Universidade de São Paulo, como exigência parcial para obtenção do Título de Doutora em Comunicação, sob a orientação do Prof. Dr. José Marques de Melo. 
Kneipp, Valquíria Passos.

Trajetória de formação do telejornalista brasileiro. Nalquíria Passos Kneipp - São Paulo, 2008

Tese (Doutorado em Comunicação) Universidade de São Paulo USP, Escola de Comunicações e Artes - ECA, 2008.

Orientador: Prof. Dr. José Marques de Melo

1. Telejornalistas - Trajetória - Brasil 2. Televisão - Brasil História 3. Telejornais - Jornalismo - História Oral 4. Telejornalistas - Modelo Americano - Telejornalismo. I. Melo, José Marques de (Orient.). II. Universidade de São Paulo, Escola de Comunicações e Artes. III. Título. 


\section{BANCA EXAMINADORA}

Prof. Dr. Antonio Carlos de Jesus

Universidade Estadual Paulista "Julio de Mesquita Filho"/Faac

Profa. Dra. Ana Carolina Pessoa Temer Universidade Federal de Goiás

Prof. Dr. Luciano Barros Maluly

Universidade de São Paulo - Eca

Prof. Dr. Luiz Fernando Santoro

Universidade de São Paulo - Eca

Prof. Dr. José Marques de Melo - Orientador Universidade de São Paulo - Eca 


\section{RESUMO}

Este trabalho propõe uma investigação a respeito de como se deu a trajetória de formação do telejornalista brasileiro, através dos mais de 58 anos de introdução da televisão no Brasil e, ainda, quais foram as implicações causadas pelo modelo americano de telejornalismo dentro deste processo evolutivo. Outra proposta do trabalho é traçar um perfil para o profissional de telejornalismo do futuro, dentro da tevê digital, processo que já foi iniciado no país.

Para o desenvolvimento da pesquisa foram entrevistados 37 telejornalistas, que exerceram ou exercem diversas funções, nas redações de telejornalismo, agrupados desde a década de 50 até 90 . As entrevistas foram orientadas pelos preceitos estabelecidos pela história oral. Além disso, a pesquisa bibliográfica e - método etnográfico, dentre outros, também foram empregados para complementar o conjunto de possibilidades metodológicas empregadas.

As conclusões do trabalho revelaram durante o processo evolutivo de formação do telejornalista brasileiro, algumas fases distintas, que foram identificadas e catalogadas, de acordo com os momentos históricos, políticos e econômicos ocorridos no país, e que a influência americana existiu e ainda existe. No entanto, as características locais, culturais e ambientais fizeram com que o telejornalismo brasileiro se tornasse único no mundo, devido às suas características próprias e pontuais.

Palavras-chave: jornalismo; história oral; telejornalista, modelo americano 


\begin{abstract}
This paper aims an investigation about how the trajectory of formation of the brazilian telejournalist, through more than 58 years of the introduction of television in Brazil. Besides, how were the implications that influenced by the American telejournalism model in this developing process. Another aim of this work is to draw a profile for the future telejournalism professionals, including those who are going to work with the digital television which has already been implemented in the country.

Jo develop this research 37 telejournalists, who hold different activities, were interviewed in this area. They were distributed in groups from the 50s until 90s. these interviews were oriented by the rules established by the oral history. Moreover, the bibliographical research and ethnographic method, among others, were used to complement the set of methodological possibilities used.

The conclusion of this paper showed that during the developing process of the brazilian telejounalism, some different phases, that were identified and recorded in a catalog, according to some historic, political and economic moments that took place in the country, along with the American influence that still exists within this process. However, the local cultural and environmental characteristics make the brazilian telejournalism unique in the world, due to its own specific features.
\end{abstract}

Keywords: Jounalism; oral history; telejournalist; American model 


\section{Agradecimentos}

Muitas pessoas foram co-responsáveis e parceiras para a realização deste trabalho. Mas algumas foram essenciais e sei que, sem o apoio delas, eu não teria conseguido chegar ao final de mais esta etapa. Desde colegas de profissão e de trabalho, que sugeriram e apoiaram esta pesquisa, até alunos de graduação deram as suas contribuições. O primeiro a me incentivar foi, sem dúvida, o amigo Luciano Maluly, que sempre confiou no meu trabalho e ajudou com o seu otimismo.

Agradeço:

Ao meu orientador, Prof. Dr. José Marques de Melo, pelo grande mérito da pesquisa em si, pois, a partir do seu olhar e da sua experiência, foi possível dar a dimensão que o trabalho merecia.

Aos co-orientadores, Prof. Dr. Antonio Carlos de Jesus e Prof. Dr. Luciano Maluly, que durante o exame de qualificação trouxeram contribuições valiosas à pesquisa.

Aos aos telejornalistas: Luiz Carlos Azenha, Luiz Antonio Malavolta, Mário Fanucci, Jacqueline Rodrigues, Carmen Amorin, Vanessa Kalil, José Carlos Aronchi de Souza, Clélia Cardin, Fernando Pacheco Jordão, Demétrio Costa, Luiz Fernando Mercadante, Paulo Roberto Leandro, Fernando Barbosa Lima, Fábbio Peres, Carlos Alberto Ballut Vizeu, Sandra Passarinho, João Batista de Andrade, Laurindo Leal Filho, Sebastião Squirra, Gregório Bacic, Eduardo Coutinho, Edson Higo do Prado, José Maria Santana, Marco Nascimento, Alfredo Vizeu, Luiz Gonzalez, Silvia Poppovic, Nelson Hoineff, Marcos Gomide, Paulo Markun, Amauri Soares, Alceu Nader, Caco Barcellos, Celso Pelosi, Alberto Luchetti, Amilcare Dalevo Júnior e Rodrigo Vianna, que cederam seu tempo e sua experiência para falar de suas carreiras profissionais no telejornalismo.

Aos alunos de graduação Marcos Joel Martins(FGF) e Juliana Mara de Souza (UAM) e pelo apoio e dedicação durante a gravação das entrevistas.

Ao Globo Universidade que apoiou as entrevista realizadas com os profissionais da casa e também cedeu material de arquivo.

As companheiras professoras Suely Maciel e Rosinei Naves pela amizade. 
Se este veículo servir apenas para divertir as pessoas e alienar, a televisão estará em perigo e logo veremos que a luta foi em vão. Este veículo pode ensinar, pode esclarecer e até mesmo inspirar. Mas, só poderá fazer isso se todas as pessoas ousarem com esse objetivo. Ou será apenas um aglomerado de fios e luzes dentro de uma caixa. Boa noite e boa sorte!

Dedico este trabalho a todas as pessoas que acreditam existir um campo de pesquisa na comunicação social, que é o telejornalismo.

Especialmente as duas pessoas mais importantes da minha vida, meu marido Daniel e meu filho Sadi, pois sem o apoio e colaboração deles este trabalho não seria possível. 
SUMÁRIO

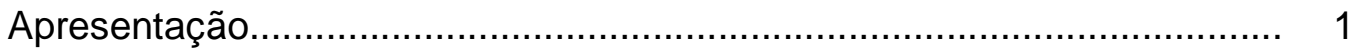

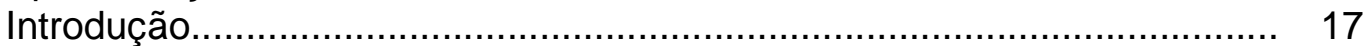

1 Capítulo 1 - Aspectos históricos do Telejornalismo 31

Brasileiro...........................................................................

1.1. Os primeiros telejornais brasileiros dos anos 50: TV Tupi, TV Paulista e 35

TV Record.

1.2. Os telejornais dos anos 60: TV Excelsior e TV Globo................................ 53

1.3. A configuração dos telejornais nos anos 70: TV Cultura e TV 69

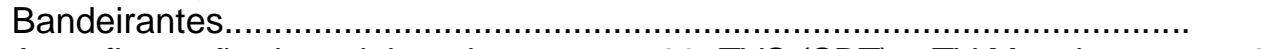

1.4 A configuração dos telejornais nos anos 80: TVS (SBT) e TV Manchete.... 72

1.5 O telejornalismo doa anos 90 até os dias atuais: Globo News, Band News 81 e All TV

2 Capítulo 2 - Aspectos históricos dos Profissionais do 89 Telejornalismo

Brasileiro

2.1 Primeira Fase - Radiofônica - décadas de 1950 e 89 1960.

2.2 Segunda Fase - Cinematográfica e Modelo Americano - décadas de 105 1970 e 1980.

2.3 Terceira Fase - Internet e SBTV$\mathrm{T}$.

3. Capítulo 3 - Os modelos no telejornalismo brasileiro

3.1 A influência dos modelos americano e europeu 163

$\begin{array}{ll}3.2 & \text { O telejornalismo brasileiro } \\ & 179\end{array}$

4. Capítulo 4 - Tendências, Desafios e Perspectiva para os 186 jornalistas brasileiros: do analógico ao digital

4.1 A formação acadêmica..................................................................... 186

4.2 A regulamentação profissional.......................................................... 197

4.3 Os impactos tecnológicos no exercício da profissão................................... 203

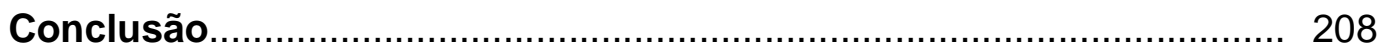

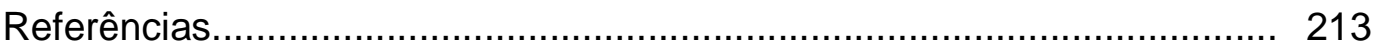

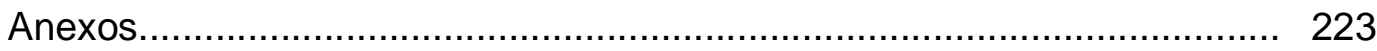




\section{APRESENTAÇÃO}

A proposta desta pesquisa foi realizar uma investigação a respeito da formação do jornalista profissional, especializado em televisão, desde a sua implantação no Brasil, nos anos 50, até os dias atuais. Foram utilizados os depoimentos de profissionais que atuaram e atuam como telejornalistas, para resgatar um pouco desta trajetória, pois seria impossível realizar uma pesquisa com a totalidade destes. Esta investigação buscou suprir uma lacuna existente dentro da história da televisão e, também, valorizar os jornalistas, que, ao longo desta trajetória, com talento, intuição e dedicação desbravaram os caminhos da profissionalização para a produção de informação na televisão, com qualidade reconhecida mundialmente. Nestes mais de cinqüenta e oito anos de implantação da tevê no Brasil foi possível acompanhar toda a evolução técnica, de conteúdo e de objetivos, através de uma extensa bibliografia existente. Faltava, porém, contar e analisar a formação do telejornalista sob a ótica dos que fizeram e fazem a televisão brasileira, e é sobre isso que se debruçou esta pesquisa. Ela pretendeu, também, comparar as fases deste processo entre si, e com o chamado modelo americano, para apresentar uma nova leitura sobre o fazer telejornalismo no Brasil.

Este trabalho é resultado da busca que sempre fiz em minha vida profissional, como editora e produtora de telejornalismo, de unir a vivência profissional com a atividade acadêmica de professora na área. Apesar da pouca valorização do campo do telejornalismo dentro da comunicação, sempre acreditei na relevância do mesmo, como elemento importante, na teria e na pratica para o jornalismo como um todo.

Foi utilizada uma amostra de 37 jornalistas especializados em televisão, e relacionados com cada uma das fases de desenvolvimento do telejornalismo, ou seja: a radiofônica, a cinematográfica, a do modelo americano, a da 
valorização do texto, a da segmentação dos conteúdos e a era digital ${ }^{1}$. Segue, abaixo, uma tabela com os nomes dos jornalistas entrevistados e as respectivas décadas em que os mesmos entraram no mercado de trabalho como telejornalistas e, ainda, as funções que os mesmos desempenharam:

\section{ENTREVISTADOS POR DÉCADA}

Década de 50

\begin{tabular}{|l|l|l|}
\hline NÚMERO & NOME & FUNÇÃO \\
\hline 1 & Mário Fanucchi & Apresentador e diretor de arte \\
\hline
\end{tabular}

Década de 60

\begin{tabular}{|l|l|l|}
\hline 2 & Clélia Cardim & $\begin{array}{l}\text { Produtora e chefe de } \\
\text { reportagem }\end{array}$ \\
\hline 3 & Demétrio Costa & Editor e diretor de jornalismo \\
\hline 4 & Fernando Pacheco Jordão & Diretor de jornalismo \\
\hline 5 & Luiz Fernando Mercadante & $\begin{array}{l}\text { Editor, chefe de redação e } \\
\text { editor-chefe }\end{array}$ \\
\hline 6 & Paulo Roberto Leandro & $\begin{array}{l}\text { Diretor de jornalismo, editor } \\
\text { regional e editor de texto }\end{array}$ \\
\hline 7 & Fernando Barbosa Lima & Diretor e produtor executivo \\
\hline 8 & Fabbio Peres & Editor chefe, editor e locutor \\
\hline 9 & Carlos Alberto Ballut Vizeu & Produtor \\
\hline
\end{tabular}

Década de 70

\begin{tabular}{|l|l|l|}
\hline 10 & Sandra Passarinho & Repórter e produtora \\
\hline 11 & João Batista de Andrade & Repórter e diretor \\
\hline 12 & Laurindo Leal Filho & Editor e diretor de jornalismo \\
\hline 13 & Sebastião Squirra & Editor, produtor executivo \\
\hline 14 & Gregório Bacic & Redator e diretor \\
\hline 15 & Eduardo Coutinho & Produtor, editor e diretor \\
\hline
\end{tabular}

Década de 80

\begin{tabular}{|l|l|l|}
\hline 16 & Edson Higo do Prado & $\begin{array}{l}\text { Coordenador de produção e } \\
\text { produtor }\end{array}$ \\
\hline 17 & José Maria Santana & $\begin{array}{l}\text { Editor, editor-chefe e chefe de } \\
\text { redação }\end{array}$ \\
\hline 18 & Luiz Antonio Malavolta & $\begin{array}{l}\text { Chefe de reportagem, } \\
\text { produtor e produtor executivo }\end{array}$ \\
\hline 19 & Luiz Carlos Azenha & Repórter e produtor \\
\hline 20 & Marco Nascimento & $\begin{array}{l}\text { Editor, produtor e diretor de } \\
\text { jornalismo }\end{array}$ \\
\hline 21 & Alfredo Vizeu & $\begin{array}{l}\text { Editor, editor-chefe e } \\
\text { professor }\end{array}$ \\
\hline
\end{tabular}

\footnotetext{
${ }^{1}$ É importante registrar que relativo à era digital serão apresentadas algumas perspectivas, apontadas pelos próprios profissionais, a respeito do rumo que a profissão de telejornalista deverá tomar.
} 


\begin{tabular}{|l|l|l|}
\hline 22 & Vanessa Kalil & $\begin{array}{l}\text { Produtora, editora e editora- } \\
\text { executiva }\end{array}$ \\
\hline 23 & Luiz Gonzalez & $\begin{array}{l}\text { Editor, editor- executivo e } \\
\text { chefe de redação }\end{array}$ \\
\hline 24 & Silvia Poppovic & Repórter e apresentadora \\
\hline 25 & Nelson Hoineff & Diretor \\
\hline 26 & Carmen Amorin & Repórter \\
\hline 27 & Marcos Gomide & $\begin{array}{l}\text { Repórter e diretor de } \\
\text { jornalismo }\end{array}$ \\
\hline 28 & Paulo Markun & $\begin{array}{l}\text { Repórter, comentarista e } \\
\text { diretor }\end{array}$ \\
\hline 29 & Amauri Sérgio Soares & $\begin{array}{l}\text { Editor, editor-executivo e } \\
\text { diretor de jornalismo }\end{array}$ \\
\hline 30 & Alceu Nader & Chefe de redação \\
\hline 31 & Caco Barcellos & Repórter \\
\hline 32 & Celso Pelosi & $\begin{array}{l}\text { Editor de texto, editor regional } \\
\text { e diretor de jornalismo }\end{array}$ \\
\hline 33 & José Carlos Aronchi de Souza & $\begin{array}{l}\text { Editor de imagens, editor de } \\
\text { texto e professor }\end{array}$ \\
\hline
\end{tabular}

Década de 90

\begin{tabular}{|l|l|l|}
\hline 34 & Alberto Luchetti & Diretor de jornalismo \\
\hline 35 & Amilcare Dalevo Júnior & Proprietário \\
\hline 36 & Rodrigo Vianna & Repórter \\
\hline 37 & Jacqueline Rodrigues & $\begin{array}{l}\text { Editora, repórter e editora } \\
\text { executiva }\end{array}$ \\
\hline
\end{tabular}

A trajetória da formação do telejornalista foi investigada a partir da coleta de depoimentos dos profissionais selecionados entre as emissoras do passado e as atuais, como TV Tupi, TV Paulista, Rede Record, TV Rio, TV Continental, Rede Excelsior, Rede Cultura, Rede Globo, Rede Bandeirantes, Rede Gazeta, SBT, Rede Manchete, Rede TV, RBS, Rede 21, TV Verdes Mares e AllTV, dentre outros canais locais ou regionais, como a TV Bauru, que apresentou uma contribuição histórica para a pesquisa. A TV Bauru foi escolhida por ter sido a primeira emissora do interior da América Latina.

A investigação servirá, também, de subsídio também para a produção de um vídeodocumentário centrado na trajetória de formação dos profissionais entrevistados, que relataram conteúdo de relevância e importância. A forma de abordagem escolhida para o vídeo se baseou no que Newton Cannito ${ }^{2}$ chamou de modelo antropológico, por buscar um diálogo com os entrevistados e

\footnotetext{
${ }^{2}$ CANNITO, Nilton. Michael Moore e os potenciais do documentário sociológico. Revista de Cinema Sinopse no 10 ano VI, dezembro de 2004: 31-33.
} 
respeitar o mundo retratado, tendo havido registro de quase todas as entrevistas com uma câmera mini-dv. Alguns entrevistados não foram registrados devido à barreiras geográficas que impediram algumas viagens. Mesmo assim, a contribuição destes se fez presente com depoimentos via internet e o envio de imagens e conteúdo de relevância ${ }^{3}$.

Com o estudo, pretendeu-se contribuir para o aprofundamento da história da tevê no Brasil, revelar algumas facetas do telejornalismo, promover um amplo debate com os profissionais da área, do passado e do presente e, ainda, fornecer subsídios para os jornalistas e estudantes que pretendem atuar ou pesquisar neste campo de trabalho.

O objetivo foi complementar algumas lacunas existentes, através da palavra dos próprios jornalistas, que, apesar de não terem tido imagem pública, tiveram importância na construção do modelo telejornalístico vigente no Brasil.

A construção histórica do profissional jornalista dedicado às atividades televisivas exigiu uma reflexão e levantamento amplo de informações, para apresentar um resgate deste percurso de formação, que caminha paralelamente com a história da tevê, no Brasil. Para tanto, é importante apresentar, inicialmente, um breve resumo da história dos telejornais no país.

O ano de 1950 foi marcado pela implantação da televisão no Brasil. Um empresário, do tipo visionário, chamado Assis Chateaubriand Bandeira de Melo, contrariando todos os indicativos de uma pesquisa que havia encomendado aos técnicos americanos, sobre a possibilidade de implantação da televisão no Brasil, decide implantá-la, mesmo com a tendência negativa apontada pela referida consulta (50 anos da TV - documentário exibido pelo TV Globo no ano de 2000). Chateaubriand, na época dono de um império chamado Diários Associados, composto por 36 emissoras de rádio, 34 jornais e 18 canais de televisão (na sua fase áurea), era um empreendedor, ao velho estilo tycoon.

\footnotetext{
3 Apenas o jornalista Celso Pelosi não foi entrevistado pessoalmente, devido à barreira geográfica e à falta de disponibilidade do mesmo, que, todavia não poupou esforços para responder a vários e-mails que supriram a necessidade da pesquisa.
} 
Desde o advento do novo meio, o jornalismo esteve presente na programação. Imagens do Dia, o primeiro telejornal da TV Brasileira, praticamente nasceu junto com a emissora pioneira, a TV Tupi de São Paulo, em 19 de setembro de 1950, um dia depois da inauguração da televisão brasileira, por Chateaubriand (50 anos da TV - documentário exibido pelo TV Globo no ano de 2000). O programa tinha estilo radiofônico, entrava no ar entre nove e meia e dez da noite. O jornalista Rui Rezende, do Imagens do Dia, era o locutor, produtor e redator das notícias, exemplo típico dos primeiros jornalistas e apresentadores do rádio, que faziam uma espécie de locução radiofônica com poucas imagens. Algumas notícias eram produzidas em filme preto e branco, sem som. O programa ficou no ar por três anos (MELLO E SOUZA, 1984: 37). Em 1954 foi substituído pelo Telenotícias Panair, um telejornal pontual, com horário certo para começar, às 21 horas, dando início ao que se conhece hoje como instantaneidade ${ }^{4}$. O Telenotícias Panair era apresentado por Toledo Pereira e ficou no ar pouco mais de um ano. Depois, veio o Repórter Esso, o primeiro telejornal de sucesso da TV brasileira. Estreou na TV Tupi de São Paulo, em 17 de junho de1953. Ficou no ar por quase 20 anos, de 1953 até 1970, e era dirigido e apresentado por Kalil Filho. Depois, com a expansão da televisão, em 1954, os cariocas ganharam a sua versão com Gontijo Teodoro. O Repórter Esso tinha horário fixo, às oito da noite, utilizava o plano americano. Levava o nome do patrocinador e seu slogan era: "Aqui fala o repórter Esso, testemunha ocular da história." (PATERNOSTRO, 1999: 35). Edição Extra foi o primeiro telejornal vespertino. Era apresentado por Maurício Loureiro Gama, na TV Tupi de São Paulo, e lançou o primeiro repórter de vídeo da TV brasileira, José Carlos de Morais, o "Tico-tico". (PATERNOSTRO, 1999: 35). Jornal de Vanguarda foi uma tentativa de criticar a situação da época e começou a ser apresentado na TV Excelsior do Rio, em 1962. Depois, foi para as tevês Tupi, Continental e Rio. Foi concebido e criado pelo jornalista Fernando Barbosa Lima e inovou com vários locutores e comentaristas, entre eles, Célio Moreira, irmão de Cid Moreira. O programa foi retirado do ar pela censura, em 1968. O Show de Notícias surgiu na TV

\footnotetext{
${ }^{4}$ A informação da TV requer "hora certa" para ser vista e ouvida - a mensagem é momentânea, instantânea. Ela é "captada" de uma só vez, no exato momento em que é emitida. Não tem como "voltar atrás e ver de novo", ao contrário de jornal ou revista (PATERNOSTRO, 1999: 64).
} 
Excelsior de São Paulo, em 1963, e ficou no ar até 1964. Dirigido pelo jornalista Fernando Pacheco Jordão, tinha a mesma linha do Jornal de Vanguarda. Com a implantação da tevê Globo em 1965, o primeiro telejornal da emissora foi o Tele Globo, que era exibido em duas edições - às 12 e às 19 horas. Em 1966, - Tele Globo passou a ter uma única edição, às 13 horas. Começou nesta época o Ultranotícias, com duas edições diárias. A primeira era apresentada por Paulo Gil Soares, às 15 horas, e a segunda, às 19 h45 era comandada por Hilton Gomes e Irene Ravache. Em setembro do mesmo ano, o telejornal ficou só com a edição noturna. Os patrocinadores do Ultranotícias eram a Ultragaz e a Ultralar, com a produção da agência de publicidade McCann Erickison. Nesta época, era comum as agências de publicidade interferirem diretamente na linha editorial dos telejornais, como acontecia também com o Repórter Esso, pois o diretor de jornalismo, na época, era o publicitário Mauro Salles. Essa situação de dependência só terminou em 1967, com a chegada de Armando Nogueira à direção de jornalismo da emissora. Ele pôs fim ao Ultranotícias e criou o Jornal da Globo, apresentado por Luís Jatobá e Hilton Gomes. Era exibido às $19 \mathrm{~h} 30 \mathrm{e}$ tinha Ramos Tinhorão como editor-chefe. Ficou no ar até 31 de agosto de 1969, dando lugar ao Jornal Nacional, primeiro noticiário em rede nacional, que entrou no ar em 1ํ de setembro de 1969, na TV Globo do Rio de Janeiro. Foi o primeiro a usar o sistema Embratel via satélite. Criado por uma equipe comandada pelo jornalista Armando Nogueira, também foi o primeiro a apresentar reportagens em cores, o primeiro a mostrar imagens, via satélite, de acontecimentos internacionais no mesmo instante em que eles ocorriam, além de inovar no estilo da linguagem e da narrativa. A figura do repórter era copiada do modelo americano, através do enquadramento, do texto curto e objetivo, e da agilidade das reportagens. O Titulares da Notícia foi o primeiro telejornal da tevê Bandeirantes, em 1967. O Bom Dia São Paulo estreou em 1977, na TV Globo de São Paulo, depois foi implantado em todas as afiliadas da Rede Globo. Constituíu a primeira experiência de telejornal matutino. Foi concebido em forma de prestação de serviços e era exibido de segunda a sexta-feira, às 7 h. Foi o primeiro telejornal a utilizar UPJ - Unidade portátil de jornalismo. Foi caracterizado, pela emissora, como Jornalismo Comunitário, apesar de não ser produzido pela comunidade, mas sim para a comunidade. A revista TV Mulher, em 1980, na TV Globo de São Paulo, foi o primeiro 
programa jornalístico dedicado à mulher e seguia o modismo do movimento de liberação feminina, consagrando a jornalista Marília Gabriela. Era exibido das 8 às 11 horas da manhã. Tinha como característica o debate de assuntos como comportamento sexual, direitos e saúde da mulher. O Bom Dia Brasil estreou em 1983, como noticiário em rede nacional, gerado em Brasília. Tinha como conteúdo, principalmente, os assuntos políticos e econômicos. Atualmente, é gerado do Rio, com participação ao vivo das praças de São Paulo e Brasília, e contém um leque de assuntos bem mais amplo. Em julho de 1980, a TV Tupi foi cassada pelo governo militar e suas emissoras foram divididas entre dois grupos empresariais: Sílvio Santos e Adolfo Bloch. Surge daí, ainda em 1980, a TVS, que posteriormente passou a se chamar SBT - Sistema Brasileiro de Telecomunicação, comandado pelo empresário Silvio Santos. Depois, em 1983, é inaugurada a Rede Manchete, do grupo Bloch, que nos anos 90 foi vendida e passou a se chamar Rede TV. O SBT resolve investir em jornalismo e lança o TJ Brasil, em 04 de setembro de 1988. Foi o primeiro noticiário brasileiro a trazer a figura do âncora, um apresentador que emite, além da informação, a opinião. O jornalista Boris Casoy conquistou o espaço com a opinião, mas ficou no SBT até 1997. (PATERNOSTRO, 1999: 37). Depois transferiu-se para a Rede Record, onde ficou até 2005. Boris Casoy também teve uma breve passagem pela TVJB, uma emissora a cabo que ficou menos de um ano no ar, em 2007. Atualmente, está apresentando o Jornal da Noite, na TV Bandeirantes. Aqui Agora foi criado em 1991, pelo SBT, para conquistar a audiência das classes C, D e E. Tinha características sensacionalistas: era apelativo, com reportagens policiais de aventura, flagrantes, denúncias, violência e tensão. Era considerado pela emissora como Jornalismo Comunitário. Saiu do ar no final de 1997. O Jornal da Band entrou no ar em 17 de fevereiro de 1997, com o jornalista Paulo Henrique Amorin como repórter, apresentador e editor-chefe. Tinha característica opinativa, pois o apresentador expressava a opinião a respeito das notícias exibidas. Ficou no ar até 12 de janeiro de 1999, nesta configuração.

A Globo News foi o primeiro canal brasileiro de jornalismo 24 horas. Está no ar desde 15 de outubro de 1996. Inicialmente, copiou o modelo americano da CNN. Depois, veio a opção pela reapresentação da programação da TV aberta. 
Possui noticiário de hora em hora e programas informativos durante toda a programação. A Band News entrou no ar em 19 de março de 2001. Tenta manter o modelo americano da $\mathrm{CNN}$, repetindo o noticiário a cada quarenta minutos, em média. Tem o visual com as tarjas azul e vermelha, típicas da CNN. Em 2002 o mesmo grupo colocou no ar o Band Sports - uma canal de notícias especializadas em esporte. No ano de 2007, a tevê Record coloca no ar a Record News - uma canal de notícias transmitido em sinal aberto.

A TV Cultura teve, em 1971, seu primeiro programa jornalístico, o Foco Noticioso, com o jornalista Nemércio Nogueira. Era um telejornal semanal, às sextas-feiras (www.tvcultura. com.br). Em 1988, colocou no ar o programa Roda Viva e, depois, no final da década de 80, o Jornal da Cultura (www.tvcultura.com.br).

Tendo em vista a história do telejornalismo brasileiro, cujos programas foram aqui breve e resumidamente apresentados, torna-se importante contar, também, a história da trajetória do profissional de jornalismo que participou deste processo e agora se prepara para dar um salto rumo à TV digital. É sobre isso que a presente pesquisa vai se debruçar, visto que a evolução dos telejornais, nestes mais de cinqüenta anos, atingiu os campos tecnológico, de conteúdos e de objetivos.

Para realizar uma pesquisa sobre a trajetória e a formação do profissional de telejornalismo no Brasil, através dos mais de cinqüenta e oito anos deste meio no país, um primeiro recorte a se fazer é listar as possíveis fases de desenvolvimento da televisão, desde a sua implantação até os dias atuais. A pesquisa também buscou traçar um panorama futuro deste profissional, visto que a TV digital e a TV pela Internet ainda são embrionárias. Conforme o modelo apresentado pelo Brasil em SRI (sistema de recuperação de imagens), o acesso ao público poderia ser garantido com a digitalização de imagens em movimento, a transmissão via internet e a utilização das novas tecnologias de compactação de vídeo (streaming) ${ }^{5}$.

\footnotetext{
${ }^{5}$ BRASIL, 2005: 127.
} 
De acordo com Mattos, as possíveis fases de evolução da televisão no Brasil podem ser dividas em seis ${ }^{6}$ :

1) A fase elitista (1950-1964), quando o televisor era considerado um luxo ao qual apenas a elite econômica tinha acesso; 2) A fase populista (1964-1975), quando a televisão era considerada um exemplo de modernidade e programas de auditório e de baixo nível tomavam grande parte da programação; 3) A fase do desenvolvimento tecnológico (1975-1985), quando as redes de TV se aperfeiçoaram e começaram a produzir, com maior intensidade e profissionalismo, os seus próprios programas, com estímulo de órgãos oficiais, visando, inclusive, a exportação destes; 4) A fase da transição e da expansão internacional (1985-1990), durante a Nova República, quando se intensificaram as exportações de programas; 5) A fase da globalização e da TV paga (1990-2000), quando o país busca a modernidade a qualquer custo e a televisão se adapta aos novos rumos da redemocratização; 6) A fase da convergência e da qualidade digital, que começa no ano 2000, com a tecnologia apontando para uma interatividade cada vez maior dos veículos de comunicação, principalmente, a televisão com a Internet e outras tecnologias. (MATTOS, 2000)

Dentro deste panorama inicial, o resgate dos profissionais de jornalismo que atuam e atuaram deu-se através das primeiras emissoras, passando pelas seis fases, que ora renomeamos para tratar do profissional telejornalista:

1-) o rádio com imagens (anos 50);

2-) a fase cinematográfica (anos 60);

3-) a cópia e adoção do modelo americano (anos 70);

4-) a valorização do texto (anos 80);

5-)a segmentação dos conteúdos e dos formatos (anos 90);

6-) e o início do caminho para a era digital (anos 2000), até chegar à atualidade do meio.

Com as emissoras já relacionadas anteriormente, buscou-se os entrevistados, que são profissionais do passado e do presente, e que desempenharam ou desempenham as funções de diretor de jornalismo, chefe

${ }^{6}$ MATTOS, 2000: 78-79. 
de redação, editor de texto, editor executivo, editor chefe, repórter, chefe de reportagem, produtor e pauteiro.

O ensino e a pesquisa em telejornalismo também corresponde a uma parte do trabalho, através da análise documental e de entrevistas com uma amostra de telejornalistas professores, a partir de Laurindo Leal Filho, Sebastião Squirra, Alfredo Vizeu, José Carlos Aronchi de Souza, entre outros.

Esta pesquisa trata de um tema que visa resgatar a história do jornalista de TV brasileiro, e, ainda, tratar da sua condição no futuro, num momento simbólico para o audiovisual no país, pois caminhamos para a TV digital ou para mais uma mudança profissional, tecnológica e estética. É necessário não só contar a história da TV no Brasil, mas fazer o resgate do jornalista dentro desta história ou, ainda, conforme propõe Marques de Melo, fazer uma ação investigativa articulada, de modo a registrar a história do jornalismo praticado no Brasil, através do que ele define como jornalismo brasileiro ${ }^{7}$.

Ao se trabalhar com a história do profissional de TV, foi importante ter em mente algumas possibilidades a serem aferidas durante o processo de formação deste jornalista, como a cópia do modelo americano ou o desenvolvimento de um modelo próprio, com características peculiares à cultura e à condição social do país. A pesquisa traçou também um panorama futuro deste profissional, visto que a TV digital e a TV pela Internet ainda são embrionárias.

Outra possibilidade é relacionar a formação do jornalista televisivo através dos tempos, com 6 diferentes pontos centrais, que estariam presentes em cada uma das fases diferentes de formação do jornalista. A primeira seria totalmente calcada no modelo radiofônico, a segunda estaria mais voltada para modelo cinematográfico, a terceira seria a adoção do modelo americano e uma padronização geral das emissoras, a quarta seria a valorização do texto, a quinta, a segmentação dos conteúdos e dos formatos, e a sexta seria o rompimento com o modelo americano e a despadronização que pode vir a acontecer com a tevê digital e pela Internet.

\footnotetext{
${ }^{7}$ MARQUES DE MELO, 2003: 13.
} 
Alguns autores foram fundamentais para o desenvolvimento desta pesquisa, principalmente os que trataram da história da TV. O ponto de partida é Marques de Melo $^{8}$, com a noção de Jornalismo Brasileiro, dentro do campo da comunicação, que torna possível a realização de pesquisa histórica com profissionais de jornalismo. Marques de Melo ${ }^{9}$ também está na base, ao situar historicamente o universo da comunicação, dando conta do desenvolvimento dos estudos de comunicação e da constituição de um campo específico de pesquisa no âmbito das ciências sociais aplicadas, através da Escola LatinoAmericana de Comunicação.

A contribuição de Beltrão deu-se com alguns subsídios sobre a teoria da comunicação de massa, na qual podemos enquadrar a televisão. Já Sampaio, com o fundamento inicial do Jornalismo Audiovisual e o primeiro conceito de telejornalismo brasileiro.

Dentre os autores que já trataram da história da TV, é importante destacar o trabalho de Sérgio Mattos, de 2000, A televisão no Brasil: 50 anos de história. Outra obra significativa dentro da pesquisa, para auxiliar o embasamento teórico, foi Comunicação e televisão - desafios da pósglobalização, de Sérgio Capparelli e Venício Lima, onde os autores analisaram o fenômeno da globalização e da pós-globalização no Brasil, levando em conta o que eles chamaram de encruzilhada digital, o que ajudou na pesquisa, a respeito desta fase de transição pela qual a televisão brasileira está passando. Carlos Eduardo Lins da Silva contribuíu com importante estudo sobre a audiência do Jornal Nacional, através de um perfil histórico da Rede Globo, na obra Muito além do jardim botânico. Uma comparação entre o jornalismo brasileiro e o americano foi observada, porque o mesmo autor buscou a origem da influencia americana no jornalismo brasileiro, no seu $O$ adiantado da Hora. Uma retrospectiva do telejornalismo brasileiro foi a contribuição de Guilherme Jorge de Rezende, ao traçar um perfil editorial do telejornalismo no Brasil. Já Sebastião Squirra, realizou uma objetiva revisão bibliográfica sobre 0 telejornalismo brasileiro, no Boris Casoy - O Âncora no telejornalismo Brasileiro. A obra mais recente que também traz a história do telejornalismo brasileiro e um recorte específico a respeito do telejornalismo da Rede Globo é

\footnotetext{
${ }^{8}$ MARQUES DE MELO, 2003.

${ }^{9}$ MARQUES DE MELO, 1998.
} 
Notícias \& Serviços nos telejornais da Rede Globo, de Ana Carolina Pessoa Temer, e, ainda, o trabalho de mestrado da mesma autora, que resgatou a história da TV Triângulo, através de depoimentos no estudo: Colhendo notícias, plantando imagens: a reconstrução da história da TV Triângulo a partir da memória dos agentes do seu telejornalismo. Um estudo sobre os manuais de telejornalismo realizado por Rúbia Vasques, em 1999, denominado $O$ Conhecimento brasileiro sobre o telejornalismo, também forneceu importante colaboração para o desenvolvimento desta pesquisa.

Sobre a Televisão, de Pierre Bourdieu, contribuiu para o desenvolvimento do trabalho, pois trata do jornalista na televisão, elemento que deverá estar inserido na questão da formação e desenvolvimento do profissional de televisão.

A pesquisa também foi complementada com artigos de jornais, periódicos especializados e entrevistas com profissionais do segmento e internet.

Através desta pesquisa, pôde-se entender o processo de evolução profissional do jornalista de televisão e até valorizar figuras que sempre estiveram nos bastidores de todo este processo, como os jornalistas sem formação acadêmica, por exemplo.

No campo prático, esta pesquisa pretendeu poder contribuir para o aperfeiçoamento do jornalista televisivo brasileiro que está em atividade e do que intenciona, no futuro, dedicar-se a esta prática.

De uma forma geral, esta pesquisa realizou um levantamento histórico, que envolveu a televisão brasileira e o jornalista profissional deste meio, para também, mais especificamente, traçar um paralelo comparativo através do tempo com cada uma das fases evolutivas e, uma perspectiva para o futuro, tanto em relação ao meio TV, quanto ao jornalista profissional.

A pesquisa intitulada Trajetória de formação do telejornalista brasileiro: as implicações do modelo americano visou:

1- analisar o processo histórico que levou ao telejornalismo contemporâneo e buscou um aprofundamento e um questionamento deste(s) momento(s) significativo (s) do jornalista profissional de TV para o país;

2- fazer uma revisão e uma reflexão crítica da história da TV no Brasil, acrescentando a atual fase pela qual o meio passa; 
3- promover um mapeamento de toda a trajetória do profissional jornalista dentro de emissoras de TV, desde a formação dele, e as transformações ocorridas no fazer jornalismo dentro de emissoras de tevê e na academia, ao longo dos mais de cinqüenta e oito anos de existência deste meio no país.

Em relação à prática jornalística, que certamente sofreu, nos últimos dez anos, uma mudança na forma de produção e que, provavelmente, ainda sofrerá outras, encontrou-se uma revolução que mudou a perspectiva sobre o jornalista profissional no Brasil. Quanto a isto, a presente pesquisa buscou: relacionar um conjunto de medidas que poderão auxiliar o novo perfil profissional para o jornalista de TV.

O material humano usado durante a pesquisa constituiu-se dos jornalistas que participaram do processo televisivo desde a sua implantação, no seu desenvolvimento e até os dias atuais. Tivemos apenas 1 jornalista que iniciou a sua atuação como telejornalista nos anos 50 , ou seja, na fase radiofônica da tevê, com idade entre de 60 e 70 anos; outros 14 jornalistas, que iniciaram-se em telejornalismo nos anos 60 e 70, época caracterizada pelo cinema e início da adoção do modelo importado dos Estados Unidos, com cerca de 40 e 50 anos de idade; mais 18 jornalistas, que iniciaram ou atuam a partir dos anos 80 até os dias atuais, com idades entre 35 e 50 anos; e outros 4 telejornalistas, que começaram a trabalhar em televisão nos anos 90. Foram selecionados, única e exclusivamente, jornalistas que exerceram ou exercem as mais variadas funções dentro do departamento de jornalismo. Não foram entrevistados técnicos e outros profissionais que fazem parte do processo do telejornal, pois esse não era o foco da pesquisa. O recorte deu-se em trabalhar apenas com os jornalistas.

As funções exercidas por estes profissionais visaram dar cabo do processo de elaboração de um telejornal do início ao final do mesmo. Por isso, foram entrevistados profissionais da produção, da edição e da apresentação e reportagem, também.

A amostra, tanto dos profissionais quanto das funções, está relacionada à amplitude da pesquisa e à própria necessidade dela, mas, no decorrer do trabalho, teve de ser readequada, quando necessário, como foi o caso dos 
jornalistas que iniciaram suas carreiras nos 50. Muitos destes profissionais faleceram no decorrer da pesquisa, como foi o caso do jornalista Paulo Patarra $^{10}$, e outros foram localizados, mas encontravam-se sem condições de conceder entrevista, por problemas de saúde, como o jornalista Armando Nogueira. Outros, ainda, não puderam contribuir por falta de horário em suas agendas como as jornalistas Neusa Rocha, Vera Íris Paternostro, Marília Gabriela, Mônica Waldvogel e Alice- Maria.

Para o desenvolvimento desta pesquisa, vários procedimentos diferentes foram utilizados e combinados. Inicialmente, uma pesquisa bibliográfica mais profunda ajudou na construção da fundamentação teórica e na melhor localização do objeto de estudo dentro do campo da comunicação.

Depois, o curso da disciplina de História Oral ampliou, alterou e afirmou os procedimentos metodológicos mais indicados para a pesquisa como um todo.

Um outro amplo levantamento bibliográfico precedeu a pesquisa de campo, para dar maior aprofundamento ao que existe sobre a história da TV brasileira e no mundo.

Num segundo momento, a pesquisa de campo, através de entrevistas com diretores de jornalismo, chefes de redação, editores de texto, repórteres, chefes de reportagem, apresentadores e pauteiros ajudou a compor a parte histórica do levantamento que se pretendeu.

O método utilizado foi a pesquisa qualitativa, através da utilização de entrevista gravada, que contém um panorama da vida profissional de cada personagem, através da história de vida ou, como também é conhecida, a história oral. De acordo com Meihy, esta é uma prática de apreensão de narrativas feitas através do uso de meios eletrônicos e destinada a recolher testemunhos, promover análises de processos sociais do presente e facilitar 0 conhecimento do meio imediato ${ }^{11}$. Esta técnica é indicada por se tratar de um assunto amplo e "aberto", de acordo com Thiollent ${ }^{12}$, que permitiu, assim, a substituição de um questionário por um simples roteiro de entrevista. Houve

\footnotetext{
${ }^{10} \mathrm{O}$ jornalista Paulo Patarra foi localizado através do Sindicato dos Jornalistas do Estado de São Paulo, em 23 de janeiro de 2008, dois dias após a sua morte impossibilitando assim a sua participação na pesquisa.

11 MEIHY, 2005: 17.

12 THIOLLENT, 1980: 33.
} 
uma readequação da premissa básica da história oral, devido às peculiaridades e às proximidades da mesma com jornalismo.

Um roteiro básico para as entrevistas foi desenvolvido e seguido, com informações como: formação, tempo de trabalho, funções exercidas, empresas e atividades desenvolvidas. Mas, em alguns casos, houve alterações em função das próprias histórias que cada personagem se propôs a contar.

Todas as entrevistas foram gravadas em vídeo digital, com uma câmera mini-dv. Esta técnica proporcionou a elaboração de um documentário em vídeo com os depoimentos relevantes, como forma de representação do universo pesquisado. Este documentário seguiu 0 modelo de abordagem antropológico $^{13}$, pois buscou o diálogo com o entrevistado e "respeitou" o mundo a ser retratado, em detrimento ao que Cannito chamou de modelo sociológico, por estar relacionado à voz do narrador e à imposição de um discurso externo à realidade retratada, pois este segundo não proporcionaria o efeito e a liberdade de expressão desejados pela pesquisa.

Os procedimentos utilizados mostraram-se os mais adequados, devido à atualidade da pesquisa e à diversidade apresentada pelo objeto de estudo, mas foram repensados e ampliados, quando houve necessidade ou possibilidade.

Os dados foram organizados através das etapas históricas, com a relação dos profissionais de cada uma delas, em suas distintas funções. Tópicos, como tempo de trabalho, funções ocupadas, atividades desenvolvidas, emissoras em que trabalharam, dentre outros, foram analisados de acordo com a história profissional de cada entrevistado.

Os dados foram interpretados através do método comparativo, entre uma fase e outra, e também em relação ao que se pretendeu definir como o modelo americano, modelo europeu e o modelo brasileiro. Também foram estabelecidas relações entre as variáveis, como rotina de trabalho, forma de apresentação, forma de produção, forma de edição de texto e imagem,

\footnotetext{
${ }^{13}$ CANNITO, 2004: 31.
} 
hierarquia dentre as funções, funções exercidas pelos jornalistas, formação do jornalista, entre outras que se mostraram relevantes e necessárias no decorrer da pesquisa.

Pretendeu-se, na conclusão da pesquisa, apresentar um resumo dos resultados alcançados nos planos teórico, metodológico, temático e prático. Outro objetivo da pesquisa foi expor as possíveis contribuições para o avanço do conhecimento sobre o profissional de televisão e da história da TV.

Um documentário produzido em vídeo digital, com alguns dos personagens que fizeram parte da história de formação do telejornalista, buscou contribuir para o entendimento, esclarecimento e valorização de pontos importantes da história da TV Brasileira. 


\section{Introdução}

Antes de entrar propriamente no objeto de estudo desta pesquisa, é preciso contextualizá-lo dentro de um campo de estudos que é a televisão, ou, como definiu o sociólogo francês Pierre Bourdieu: "campo televisual, subcampo que está englobado no campo jornalístico" (BOURDIEU, 1997: 75). Essa noção adotada por ele ajuda a entender a divisão e a proximidade entre televisão e jornalista especializado em televisão, que a partir de agora será chamado de telejornalista.

O campo televisual exige um profissional com uma formação muito direcionada para as rotinas próprias do meio. É preciso, inicialmente, ter o domínio do que pode ser chamado de linguagem televisiva, bem como o entendimento da estrutura básica que está por trás deste meio de comunicação de massa. Esta estrutura básica foi relacionada por Paternostro (1999: 64-65), com os seguinte elementos: informação visual, imediatismo, alcance, instantaneidade, envolvimento, superficialidade e índice de audiência.

Mas esta estrutura e esta linguagem, próprias da televisão, nem sempre foram tão claras como são para o profissional que atua nos dias de hoje. Nos anos 50, quando a tevê foi implantada no Brasil, o que havia era a utilização da linguagem radiofônica, por um veículo que tinha imagens à acrescentar ao texto lido pelos locutores. A este respeito, Bourdieu faz uma correlação com a tevê francesa da mesma época, mas com uma visão mais crítica dela: "A televisão dos anos 50 pretendia-se cultural e de certa maneira servia-se de seu monopólio para impor a todo mundo produtos com pretensão cultural..." (BOURDIEU, 1997: 68). No Brasil, esta fase dos anos 50 ficou conhecida como rádio com imagens, pois locutores do rádio foram importados automaticamente para as primeiras emissoras de televisão e, como não havia nenhuma orientação, eles acabaram repetindo o que já faziam no rádio.

Depois, nos anos 60, houve uma aproximação com o cinema, onde muitos cineastas passaram a atuar também na televisão. Esse fato trouxe uma melhoria na qualidade das imagens, mas o texto continuava inexpressivo. Para o Brasil nesta década, segundo Becker: 
a imprensa, a literatura e o rádio tiveram um papel fundamental na construção da sociedade brasileira até a década de 60 , quando a TV aberta foi considerada como instrumento de integração e ordem nacional. (BECKER: 2005: 15)

Isso porque, com a ditadura, começou a censura, e a televisão, por se tratar de uma concessão pública, estava atrelada ao poder dos militares, conforme relatou o jornalista Armando Nogueira:

Nós, os jornalistas, não estávamos preocupados em fazer no Jornal Nacional, um belo jornalismo, porque isso não seria possível debaixo de uma censura que era exercida de forma rigorosa, severa e, como toda censura política, arbitrária e indiscriminada. (MELLO E SOUZA, 1984: 9)

A partir da metade da década de 60 e início da de 70, houve a cópia e a adoção do que conhecemos como modelo americano, a partir da Rede Globo de Televisão e da implantação do primeiro telejornal em rede, o Jornal Nacional, que entrou no ar no dia $1^{\circ}$ de setembro de 1969. A emissora, em termos de jornalismo, vivia numa "ilha de tranqüilidade", devido ao cerco que a censura fazia por todos os lados, em termos de liberdade de informação. (MELLO E SOUZA, 1984: 96). O foco passou, então, a ser o noticiário internacional, onde não havia nenhum tipo de censura prévia. Outro problema foi a dificuldade de contratar bons jornalistas do impresso, com grande experiência e vivência profissional, porque, conforme Souza, seria o mesmo que passar do conforto de seis laudas datilografadas para o desafio de resumir tudo em seis linhas (MELLO E SOUZA,1984: 145). Com esse cenário, para Armando Nogueira, foi mais fácil contratar bons profissionais no exterior: "Quem se atreveria, aqui no Brasil, a trocar uma situação tolerável nas redações dos jornais impressos, por uma situação absolutamente intolerável na televisão?" (MELLO E SOUZA, 1984: 95).

Os anos 80 têm a contribuição da academia, através dos professores especializados em telejornalismo, e também a chegada nas redações dos jornalistas oriundos do impresso, com maior facilidade, devido ao processo de abertura política pelo qual o Brasil passava. Tinha-se a perspectiva de que a televisão era algo sem muita qualidade e conteúdo informacional, por isso, os 
jornalistas do impresso e sem nenhuma experiência em televisão foram recrutados.

Na década de 90, houve a segmentação dos conteúdos e formatos, com a chegada da TV a cabo e com a criação de emissoras de notícias 24 horas por dia, como a Globo News e a Band News, canais especializados em notícias.

No novo milênio, a preocupação passa a ser a nova configuração do padrão televisivo brasileiro: a TV digital. Como será a profissão do telejornalista? Quais as necessidades profissionais a serem exigidas? Qual será o caminho do telejornalista no futuro da TV digital e via internet?

É através destas seis décadas, tão importantes e tão significativas para a formação telejornalista, que esta pesquisa focou suas etapas constitutivas, através de seis blocos.

Partindo de questões tão importantes, como estrutura e linguagem, surge a possibilidade e, agora, até a necessidade, de revisitar a trajetória de formação por que passou o telejornalista. Como foi construído e acumulado este conhecimento específico para o exercício desta profissão? $E$ ninguém melhor que os próprios telejornalistas para ajudar a responder esta e outras questões relativas a este passado.

Para dar cabo desta perspectiva, o método, a técnica ou até mesmo o estatuto da História constituiu importante ferramenta para auxiliar no desenvolvimento desta pesquisa. Colocando, assim, os entrevistados na perspectiva de colaboradores, com vez e voz de opinar e dar sugestões relativas ao andamento da pesquisa.

Muitos pesquisadores já falaram sobre as várias histórias que se pode contar ao longo destes mais de 58 anos de implantação da televisão no Brasil. Mas, o objetivo desta pesquisa foi, através de um resgate histórico, documental e testemunhal, acompanhar como foi a trajetória de formação do profissional de jornalismo na televisão brasileira. A construção ou reconstrução desta trajetória poderá contribuir para o aprofundamento teórico do jornalismo televisivo, traçar paralelos evolutivos entre as décadas e verificar, pontualmente, como ocorreu o fenômeno da formação do telejornalista brasileiro, e, ainda, verificar a influência americana neste percurso. 
A televisão, desde a sua implantação, sempre esteve no centro das atenções do cidadão brasileiro, como companheira, informante e até cúmplice. A TV atinge 99,9\% do território nacional. No Brasil, esta pesquisa foi levada a cabo devido ao grande espaço que o veículo televisão ocupa na vida das pessoas, nos espaços universitários e nas reflexões teórico-práticas, pois, de acordo com opinião do repórter Edward R. Murrow, no filme Boa Noite e Boa Sorte:

\begin{abstract}
Se este veículo servir apenas para divertir as pessoas e alienar, a televisão estará em perigo e logo veremos que a luta foi em vão. Este veículo pode ensinar, pode esclarecer e até mesmo inspirar. Mas, só poderá fazer isso se todas as pessoas ousarem com esse objetivo. Ou será apenas um aglomerado de fios e luzes dentro de uma caixa. Boa noite e boa sorte!
\end{abstract}

Isto significa dizer também que a televisão, parafraseando o sociólogo Octávio lanni, pode ser chamada de o Príncipe Eletrônico, em relação ao Príncipe de Maquiavel, e com referência à importância da televisão na vida da população, porque, para ele a tevê é:

a fábrica de hegemonia e da soberania, que teriam sido prerrogativas do Príncipe de Maquiavel e do Moderno Príncipe de Gramsci; agora é o Príncipe Eletrônico que detém a faculdade de trabalhar a virtude e fortuna, a hegemonia e a soberania; ou o problema e a solução, a crise e a salvação, o exorcismo e a sublimação. Assim se instaura o imenso agora eletrônico, no qual muitos navegam, naufragam ou flutuam buscando salvar-se (IANNI, 1998).

A televisão é o único meio de informação para muitas pessoas, principalmente no Brasil, um país em desenvolvimento, onde há uma das maiores desigualdades de renda "per capita" do mundo, perdendo apenas para Serra Leoa, de acordo com Organização das Nações Unidas. Pode-se até traçar um paralelo com Bourdieu, onde ele afirma que na França: "a televisão pode reunir em uma noite diante do jornal das 20 horas mais pessoas do que todos os jornais franceses da manhã e da noite reunidos" (BOURDIEU,1997: 62). Isto, no Brasil, ocorre de modo similar, segundo números do IBOPE .

A televisão aparece sempre em destaque, ou sempre junto, mesmo que o objeto desta pesquisa tenha sido a trajetória de formação do telejornalista, devido à proximidade dos dois ou até à própria hibridação dos mesmos. Mas esta pesquisa não envolveu outros formatos, se não informativos, da televisão brasileira. De acordo com Aronchi de Souza, existem cinco categorias de 
programas na televisão brasileira, a saber: entretenimento, informação, educação, publicidade e outros. Dentro destas categorias, existem gêneros. $O$ que vem ao caso desta pesquisa é a categoria informação, que tem como gêneros o debate, o documentário, a entrevista e o telejornal. (ARONCHI, 2004: 92).

A presente pesquisa está diretamente ligada à história da televisão brasileira, mas com um enfoque específico no profissional de jornalismo que se formou nestes mais de cinqüenta e oito anos de implantação da TV no Brasil. Isso significa esclarecer que alguns autores, que já se debruçaram sobre o mapeamento da história da televisão brasileira, foram referências ou pano de fundo para o passo adiante que esta pesquisa pretende dar, ressaltando que 0 recorte específico pretendido é traçar a trajetória de formação, ao longo dos anos, do profissional que está na linha de informação das emissoras de TV. Pretendeu, ainda, levar em consideração as influências ocorridas de alguns outros modelos, inclusive o americano, que é tido como o referencial para o desenvolvimento de um modelo brasileiro. De acordo com Prado:

O padrão Globo de qualidade era fortemente influenciado pelo padrão norteamericano, com a preocupação de fazer televisão usando toda a sua força, ou seja, explorando o potencial das imagens, coisa que ainda não se fazia por aqui, especialmente no telejornalismo. (PRADO, 1996: 11)

Essa idéia de padrão de qualidade surgiu na tevê Globo, devido aos erros que eram cometidos durante a exibição do telejornal, nos primórdios da emissora. A maior parte dos erros acontecia devido às falhas técnicas dos equipamentos, onde a primeira medida era colocar no ar um slide de "emergência" até se conseguir resolver o problema. Depois de resolvido o problema técnico, o locutor entrava e dizia: "Desculpe a nossa falha técnica". Causava-se assim, um constrangimento aos técnicos, que alegavam não ser uma falha técnica, mas do equipamento ou da operação. Por isso, com o tempo, evoluiu-se para a fórmula "desculpe a nossa falha", para que a culpa não recaísse somente no quadro técnico da emissora.

A televisão, de acordo com Popper e Condry, tem um poder incontrolado e que isso contradiz os princípios da democracia (POPPER e CONDRY,1999: 11). Este poder incontrolado pode ser percebido claramente no Brasil, ao se 
verificar os altos índices de audiência de algumas emissoras e a reprodução da cultura que é passada por ela e copiada por boa parte da população, e que reflete a cultura do eixo Rio - São Paulo, em detrimento do local e do regional. A vida num estado do nordeste mostrou-me a recusa de um padrão nacional reproduzido pela televisão, em confronto com a cultura popular nordestina. Isso só ocorre no caso das emissoras regionais e locais, que não estão atreladas a uma grande rede de repetidoras. Outro ponto questionado por Popper e Condry é o baixo nível da programação da televisão para manter a audiência, mostrando que as redes de televisão produzem programas cada vez mais sensacionalistas, porque a audiência quer (POPPER e CONDRY,1999: 17). No caso do telejornalismo, o sensacionalismo provoca um verdadeiro fascínio no telespectador, mas esse fascínio, com o passar do tempo, satura e provoca repúdio, como aconteceu com o precursor deste gênero, que foi o Aqui Agora. Os níveis de audiência desse telejornal alcançaram números significativos, entre 28 e 32 pontos no IBOPE, mas com o tempo e a repetição insistente da mesma fórmula, perdeu audiência e teve que sair do ar. Esse fascínio pelo sensacional, em termos de Brasil, só perdura na região nordeste, onde temos, por exemplo, na cidade de Fortaleza, cerca de oito horas diárias de telejornais sensacionalistas, com foco em notícias policiais.

O instrumental metodológico selecionado para a elaboração desta pesquisa não foi simples, nem pôde se limitar a um único, mas sim a uma parafernália, com a combinação de vários instrumentos de diversas áreas do conhecimento, como história, sociologia e jornalismo.

O primeiro deles refere-se ao estatuto defendido pela História Oral, que tem por um lado Sebe, com a definição de alguns conceitos. O número um é a prática de narrativas gravadas por meios eletrônicos (gravadores de áudio e/ou de áudio e vídeo) de testemunhos, com posterior análise. O número dois prevê a elaboração de documentos, a partir das narrativas colhidas. No número três, existe a elaboração de um projeto, com um conjunto de procedimentos. Neste projeto, foi feita a definição de um grupo de pessoas (ou colônia), a serem entrevistadas. No caso desta pesquisa, as colônias foram formadas pelos telejornalistas, através da divisão por década. Também fez parte da pesquisa o planejamento da condução das gravações, transcrição, conferência da fita com o texto, autorização para o uso, arquivamento e, sempre que possível, 
publicação dos resultados, que devem, em primeiro lugar, voltar ao grupo que gerou as entrevistas. O conceito número quatro propõe o uso de depoimentos gravados e depois transformados em texto, como uma alternativa para o estudo da sociedade. $\mathrm{E}$, finalmente, no conceito número cinco, o uso de entrevistas gravadas e depois transcritas, do oral para o escrito, como um processo sistêmico para o uso de depoimentos (MEIHY, 2005: 17 - 18).

Por outro lado, a história oral, através de Freitas, tem outros procedimentos e possibilidades e tem como principal finalidade criar fontes históricas (FREITAS, 2006: 6). Freitas esclarece, também, a subdivisão que classifica esta pesquisa como história oral temática, pois todos os colaboradores foram entrevistados sobre a (s) sua(s) atuação (ões) como telejornalista (s), portanto:

a entrevista tem caráter temático e é realizada com grupo de pessoas, sobre um assunto específico. Essa entrevista - que tem característica de depoimento - não abrange necessariamente a totalidade da existência do informante. Dessa maneira, os depoimentos podem ser mais numerosos, resultando em maiores quantidades de informações, o que permite uma comparação entre eles, apontando divergências, convergências de uma memória coletiva, por exemplo (FREITAS, 2006: 8)

Através da História Oral, segundo Meihy, o primeiro passo é o estabelecimento da Comunidade de Destino como sendo os comunicadores, que atuam ou atuaram em emissoras de televisão, desde a sua implantação no Brasil, no dia 18 de setembro de 1950, e ainda, os estudantes, professores e pesquisadores de telejornalismo.

Dentro desta Comunidade de Destino, a Colônia foi formada pelos jornalistas de TV, ou seja, os telejornalistas. As redes foram organizadas por décadas $(50,60,70,80$ e 90$)$ e por sexo: masculino e feminino.

\begin{tabular}{|l|l|l|}
\hline \multicolumn{1}{|c|}{ Comunidade de destino } & \multicolumn{1}{|c|}{ Colônias } & \multicolumn{1}{c|}{ Redes } \\
\hline $\begin{array}{l}\text { Comunicadores, estudantes } \\
\text { e pesquisadores }\end{array}$ & 01 Telejornalista & Rede dos anos 50 \\
\hline & 08 Telejornalistas & Rede dos anos 60 \\
\hline & 06 Telejornalistas & Rede dos anos 70 \\
\hline & 18 Telejornalistas & Rede dos anos 80 \\
\hline & 04 Telejornalistas & Rede dos anos 90 \\
\hline
\end{tabular}


A área geográfica de cobertura desta pesquisa deverá se restringir à região sudeste, levando como referenciais os estados de São Paulo e Rio de Janeiro, mas também foi incluída uma amostra em outras regiões, como Pernambuco, Ceará, Minas Gerais e Rio Grande do Sul.

O ponto zero foi o jornalista Gregório Bacic. Ele ajudou na escolha das Redes de entrevistados, que estão, inicialmente, separados por gerações, a partir dos anos 50. A entrevista com o ponto zero aconteceu no dia 21 de setembro de 2005, e contou com os seguintes questionamentos:

1- Desde quando você trabalha em tevê?

2- Em quais emissoras você já trabalhou?

3- Quais foram as funções que já exerceu?

4- Quais eram as atividades desenvolvidas em cada uma das funções exercidas?

5- Como você avalia a importância do seu trabalho na tevê?

6- Quais eram as características necessárias para se trabalhar na tevê nos anos 60 ?

7- E nos anos seguintes, houve alterações no nível de exigências profissional para a tevê?

8- Comente a sua rotina de trabalho na época.

9- Fale sobre a equipe de trabalho.

10- Fale sobre a hierarquia da redação.

Ao todo, foram cinco Redes de colaboradores, através das gerações, com alguns entrevistados em cada década, conforme a tabela da página 23.

A primeira rede, dos anos 50 - os primórdios na implantação da TV modelo radiofônico ou rádio com imagens;

A segunda rede, dos anos 60 - influência americana $X$ influência cinematográfica; nos anos 60, o acordo entre a Rede Globo e o grupo norteamericano Time Life trouxe tecnologia e treinamento aos profissionais da emissora; em paralelo, profissionais oriundos do cinema acabaram trabalhando nas emissoras de TV, resultando, o que vai se tentar mostrar, no que foi a influência cinematográfica no telejornalismo brasileiro.

Nos anos 70, na terceira rede - a cópia do modelo americano já estava efetivada, quando o acordo entre a Rede Globo e o grupo Time Life terminou; o 
telejornalismo já estava reproduzindo exatamente o formato e a linguagem americana;

A quarta rede, dos anos 80 - houve a valorização do texto, com a vinda dos jornalistas do impresso para a televisão; nesta fase, com a criação de duas novas redes, Manchete e SBT, o modelo americano passou a fazer parte de todas as emissoras;

$\mathrm{Na}$ quinta rede, dos anos 90 - houve a segmentação dos conteúdos e dos formatos, com a chegada das emissoras em UHF e da tevê a cabo, com os canais de notícias 24 horas e, ainda, as readequações para um modelo latinoamericano; acredita-se que neste período, com a chegada de telejornais, como Aqui Agora, e do primeiro Âncora brasileiro, o telejornalismo recebeu também a influência da América Latina e dividiu a audiência que, até então, era monopolizada pela Rede Globo;

A perspectiva diferencial do entrevistado, através do viés da História Oral, apresentou o mesmo acoplado ao projeto como um "colaborador", e não como um simples entrevistado. Isso é um fator essencial para esta história que se pretende contar, pois os livros e as pesquisas jornalísticas já contam e mostram a história oficial sem que se possa perceber a presença e a participação dos envolvidos no processo. A prioridade desta pesquisa foi a experiência individual e a participação efetiva do "colaborador" durante todo o processo. Aqui, a experiência que se pretendeu foi a: "da retomada salvadora da palavra de um passado que, sem isso, desapareceria no silêncio e no esquecimento" GAGNEBIN, Jeanne Marie. E, de acordo com Ricardo Marcelo Fonseca: "Benjamin distingue a "experiência" - enquanto tradição coletiva, como algo que encontra raízes remotas, como a tradição dos provérbios, do "contar" uma história de pai para filho, como a transmissão da sabedoria dos velhos para os mais novos - da simples "vivência", muito mais fugaz, desapegada e desenraizada, e que progressivamente vai substituindo a primeira. Assim sendo, muitos colaboradores se colocaram também, como parte integrante da pesquisa, e indicaram novos entrevistados, que poderiam ajudar com seus depoimentos.

A primeira Rede de colaboradores, dos anos 50 - implantação da TV rádio com imagens contou com um único entrevistado, Mário Fanucchi. $\mathrm{O}$ 
critério de seleção utilizado foi em função das pessoas que puderam ser encontradas, pois boa parte dos jornalistas da época já faleceu, devido à faixa etária, entorno de 70 ou 80 anos de idade. O questionário utilizado foi: 1- Como você foi trabalhar na tevê?; 2- Que tipo de experiência era necessária para o trabalho?; 3- Como era o trabalho do jornalista naquela época?; 4- Quais as funções que desempenhou nos cargos que ocupou? 5- Comente o processo de elaboração de um telejornal? 6- Conte histórias da (s) emissoras em que trabalhou.

A segunda Rede de colaboradores, dos anos 60 - fase cinematográfica, contou com os seguintes entrevistados: Clélia Cardim, Demétrio Costa, Fernando Pacheco Jordão, Luiz Fernando Mercadante, Paulo Roberto Leandro, Fernando Barbosa Lima, Carlos Alberto Ballut Vizeu e Fabbio Peres. O critério de seleção buscou encontrar profissionais que tivessem trabalhado nas diversas emissoras existentes na época, mas teve que ser readequado no caso de alguns entrevistados que não concordaram ou não estavam acessíveis, como, por exemplo, Alice Maria e Armando Nogueira. O questionário utilizado foi: 1- Como você trabalhar na tevê? 2- Qual era a experiência que possuía? 3- Como era o trabalho diário? 4- Qual era a hierarquia da redação? 5- Conte histórias de trabalho.

A terceira Rede de colaboradores, dos anos 70 - cópia e adoção do modelo americano teve os seguintes colaboradores: Sandra Passarinho, João Batista de Andrade, Laurindo Leal Filho, Sebastião Squirra, Gregório Bacic e Eduardo Coutinho. O critério de seleção balizou-se pelas funções exercidas por cada profissional e a relevância do trabalho realizado. O questionário utilizado teve o mesmo conteúdo da rede anterior. Os jornalistas Laurindo Leal Filho e Sebastião Squirra também atuaram e atuam como professores de telejornalimo. Alguns jornalistas não concederam entrevista, por falta de espaço na agenda, como Neusa Rocha, Carlos Nascimento e Mônica Waldvogel.

A quarta Rede de colaboradores, dos anos 80 - valorização do texto teve a participação dos seguintes colaboradores: Edson Higo do Prado, José Maria Santana, Luiz Antonio Malavolta, Luiz Carlos Azenha, Marco Nascimento, Alfredo Vizeu, Vanessa Kalil, Luiz Gonzáles, Silvia Poppovic, 
Nelson Hoineff, Carmen Amorin, Marcos Gomide, Amauri Sérgio Soares, Alceu Nader, Caco Barcellos, Celso Pelosi, José Carlos Aronchi de Souza e Paulo Markun. O critério de seleção buscou encontrar profissionais que tivessem exercido as diferentes funções já estabelecidas como editor de texto, repórter, chefe de reportagem, chefe de redação e diretor de jornalismo. O questionário utilizado teve o mesmo conteúdo da segunda rede e ainda outro específico para professores de telejornalismo (como Alfredo Eurico Vizeu), a saber: 1-) Como você foi lecionar telejornalismo?; 2-)Que tipo de experiência era necessária para ensinar esta disciplina?; 3-) Como você se tornou professor de telejornalismo? (cursos/ especialização/ mestrado / doutorado); 4-)Como eram as aulas de telejornalismo quando você começou lecionar ?; 5-) Qual a metodologia você adotou para ensinar os conhecimentos práticos?; 6-) As aulas eram mais teóricas ou práticas?; 7-) Quais os autores (bibliografia) que você adotou?; 8-) Quais os equipamentos disponíveis na universidade para que os alunos pudessem praticar telejornalismo?; 9-) Como era feita a avaliação dos alunos? (baseava-se em teoria ou em prática); 10-) Comente o processo de elaboração de um telejornal na universidade?; 11-) Que tipo de exercício prático os alunos desenvolviam?; 12-) Na sua opinião o telejornalismo brasileiro copiou o modelo americano e mantém até hoje? Por que?; 13-) Conte histórias da (s) universidade (s) que trabalhou? Nesta rede, alguns nomes de relevância, como a jornalista Vera Íris Paternostro, não atenderam às muitas solicitações de entrevista.

A quinta Rede de colaboradores, dos anos 90 - a segmentação dos conteúdos e dos formatos, contou com os seguintes colaboradores: Alberto Luchette, Amilcare Dalevo, Rodrigo Vianna e Jacqueline Rodrigues. O critério de seleção baseou-se nas principais emissoras de tevê aberta e segmentada, de acordo com a audiência e existência de departamento de jornalismo. $O$ questionário utilizado teve o mesmo conteúdo da segunda rede. Alguns jornalistas também ficaram sem prestar depoimento, por falta de interesse ou de agenda, como no caso de Humberto Candil, Marcos Humel e Fátima Bernardes.

Estas cinco redes de colaboradores não foram únicas e nem absolutas. Elas estiveram sempre em transformação, devido a fatores como dificuldade de 
encontrar os jornalistas, a falta de interesse dos mesmos em participar e até mesmo falta de condições físicas e de tempo.

Os entrevistados também foram estimulados a indicar nomes, através da técnica da bola de neve, que de acordo com a necessidade da pesquisa, também foram incorporados ao trabalho por sugestão dos colaboradores.

A metodologia da História Oral, segundo Meihy, "não procura a verdade, mas a experiência" traz uma perspectiva dialética, com base em três momentos, após a entrevista: na primeira fase, a transcrição literal da entrevista gravada por meio eletrônico; na segunda fase, a textualização, que consiste basicamente na retirada das perguntas; e numa terceira, denominada de transcriação, onde se fará um rearranjo do texto, pois, "na tradução do oral para o escrito não é possível traduzir sem mudança”. Uma etapa posterior consiste na negociação com o colaborador, onde o texto é apresentado para ele, para que o mesmo possa autorizar ou opinar, em parceria com o pesquisador, sobre o quê e como deve ser apresentado o material final. Esse processo não foi levado a cabo, pelo menos até o encerramento da pesquisa, pois não haveria espaço para o texto transcriado no corpo da tese, em face do grande número de entrevistados, com gravações que variaram de vinte e cinco minutos no mínimo, até uma hora e meia. Colocando no papel houve uma variação de cinco até oito laudas transcritas, por entrevistado. Essa etapa deverá ser desenvolvida após o término da tese.

Ainda no aspecto metodológico, vem a importante contribuição da sociologia, através do método etnográfico, que também não pôde ser usado de forma contínua, mas somente na etapa que se refere à época atual, onde já se está preparando o telejornalista para a tevê digital.

O método etnográfico, de acordo com Travancas (in: DUARTE e BARROS, 2005: 95), consiste em estabelecer relações, selecionar informantes, transcrever textos, levantar genealogias, mapear campos, manter um diário, entre outras medidas. Nesta pesquisa, em cada entrevista, buscou-se o resgate de textos e materiais guardados pelos entrevistados, a indicação de novos entrevistados e, através do próprio depoimento, mapear a trajetória do telejornalista. A etnografia, como parte do trabalho de campo, trata-se de uma pesquisa qualitativa, pois permite uma aproximação com o objeto, conforme propõe Travancas: 
Ela exige um 'mergulho' do pesquisador, ou seja, não é um tipo de pesquisa que pode ser realizada em um período muito curto e sem preparo. É fundamental, como etapa anterior à etnográfica propriamente dita, um levantamento bibliográfico sobre o tema. (in: DUARTE e BARROS, 2005: 100)

Do jornalismo, vem a concepção básica deste trabalho, pois a vivência jornalística propõe a entrevista como um método muito importante e revelador. Mas, como trata-se de um trabalho científico, com fins reflexivos, a tipificação para as entrevistas realizadas foi o que Duarte chama de entrevista em profundidade (grifo meu), pois: "a entrevista em profundidade é a técnica qualitativa que explora um assunto, a partir da busca de informações, percepções e experiências de informantes, para analisá-las e apresentá-las de forma estruturada" (in: DUARTE e BARROS, 2005: 62). Esta abordagem permite maior liberdade, tanto para o entrevistado, quanto para o entrevistador. Neste caso, o objetivo do uso da entrevista em profundidade é a descrição do processo de trabalho no qual o entrevistado está ou esteve envolvido durante algum tempo.

A entrevista em profundidade pode ser aberta, semi-aberta ou fechada, segundo Duarte. No caso específico desta pesquisa, a tipificação escolhida foi a semi-aberta, por se julgar mais compatível com os objetivos a serem atingidos e também por identificar a existência de um roteiro de controle, podendo ser adaptado ou alterado, de acordo com o entrevistado. Outro motivo para esta escolha é a utilização livre do roteiro, pois ele permite a comparação das respostas e articulação dos resultados, auxiliando a sistematização das informações fornecidas por diferentes entrevistados (in: DUARTE e BARROS, 2005: 67).

A seleção dos entrevistados procedeu-se através de uma mescla entre os dois tipos básicos de amostras não probabilísticas para o uso em entrevistas qualitativas, que Duarte denomina de: por conveniência ou intencional. Segundo ele, a seleção por conveniência, também chamada acidental, "é baseada na viabilidade. Ocorre quando as fontes são selecionadas por proximidade ou disponibilidade". Em alguns casos, critérios como a proximidade da pesquisadora com os profissionais e a disponibilidade dos mesmos, ajudaram na seleção e na aceitação em participar de uma pesquisa 
acadêmica. Por outro lado, também houve a seleção intencional, "quando o pesquisador faz a seleção por juízo particular, como conhecimento do tema ou representatividade subjetiva" (in: DUARTE e BARROS, 2005: 69), pois a experiência profissional e a pesquisa bibliográfica proporcionaram 0 conhecimento do tema, a ponto de determinar, intencionalmente, alguns entrevistados essenciais ao trabalho.

Mesmo sendo considerada por Moreira como uma fonte secundária, a análise documental também é um recurso, que, neste caso, ajudou no resgate da história dos telejornais brasileiros. Pois, numa fase posterior da pesquisa de campo, houve uma consulta a documentos oficiais, a respeito da concessão de canais de televisão no Brasil (in: DUARTE e BARROS, 2005: 270). Este método, segundo Moreira, "como explica a própria designação documental, compreende a identificação, a verificação e a apreciação de documentos para determinado fim" (in: DUARTE e BARROS, 2005: 271). Neste caso, o uso desta técnica ou método visa complementar as informações conseguidas por outras formas. 


\section{Capítulo 1 - Aspectos Históricos do Telejornalismo Brasileiro}

No cocuruto do Banco do Estado tinha sido instalada a antena que ia levar pioneiramente aos lares paulistanos o mais subversivo do todos os veículos de comunicação do século, a televisão. Assis Chateaubriand Bandeira de Melo, no dia da inauguração da televisão no Brasil (MORAIS, 1994: 502)

Antes de entrar propriamente nos telejornais cabe-nos registrar, mesmo que repetitivamente, parte do início da implantação da televisão no Brasil e do seu personagem principal, que também ficou conhecido como Chatô. Chamado de pioneiro a picareta, entre seus amigos e inimigos, Chatô é figura representativa na história das comunicações no Brasil.

A televisão foi implantada no país, no dia 18 de agosto de 1950, pelo visionário Assis Chateaubriand Bandeira de Melo. Ele ousou e, contrariando as pesquisas de técnicos americanos que apontavam o Brasil como um país ainda muito insipiente para tal tecnologia, inaugurou a primeira emissora, que inicialmente chamou-se PRF-3 e algum tempo depois passou a ser a TV Tupi de São Paulo - Canal 4. Chateaubriand merece ser lembrado pela sua coragem e visão além de seu tempo.

Francisco de Assis Chateaubriand Bandeira de Melo nasceu em Umbuzeiro, na Paraíba, em quatro de outubro de 1892. O pai, Francisco José, era juiz municipal. A mãe, Maria Carmem Gondim, deu-lhe o nome em homenagem à devoção ao padroeiro. A data facilitou a escolha, pois era o Dia dos Animais e de São Francisco de Assis. Assim, foi lhe dado um nome comum, como o de tantos outros meninos com nomes de santos dados no Nordeste até os dias de hoje.

Quando pequeno, Chateaubriand custou a falar. A dificuldade que tinha de pronunciar uma única palavra, provocava risos dos mais velhos. Era gago. Entrou na escola e tudo piorou. Os colegas caçoavam e ele resolveu não falar mais. O médico da família aconselhou uma mudança da cidade para o campo, para que o menino pudesse se soltar. Mandaram o menino morar com o avô materno, em Belém, no Pará. Voltou ao normal, mas continuou gago. Só com o 
exercício contínuo da leitura perdeu a gagueira. Aprendeu a ler, escrever e fazer contas. "Mas ainda pequeno, mudou-se com a família para o Recife, em Pernambuco, onde viveu até dar início à sua aventura no sul do país, para tornar-se um dos homens mais poderosos do Brasil." (PATERNOSTRO, 1999: 27).

Seu primeiro trabalho foi na Othon Mendes \& Cia. Depois, acabou realizando o sonho de trabalhar num jornal, $A$ Gazeta. Em 1907, o jornal foi à falência e Chateaubriand ficou desempregado. Aproveitou o tempo livre para estudar e entrou na faculdade de direito. Foi contratado pelo "Jornal do Recife". Foi mandado embora, por escrever artigos que contrariavam a política do jornal, a respeito da polêmica entre Hermes da Fonseca e Manuel de Oliveira Lima.

Como pretendia publicar, a qualquer custo, o artigo "Em defesa de Oliveira Lima", patrocinou do próprio bolso um folheto que the rendeu fama e um salário de cem réis no jornal "A Cidade".

Depois, atuou como advogado e acabou conhecido no Rio de Janeiro. Em 1918, assume a direção do Jornal do Brasil. Em seguida, passa três anos na Alemanha, como correspondente internacional do Correio da Manhã. Em 1921, lançou o livro "Alemanha”.

O ano de 1922 é marcado pela discussão com os artistas da Semana de Arte Moderna. Para ele, tal semana não seria mais do que uma semana de secos e molhados, e também pela compra do seu primeiro jornal.

Talvez nesta época tenha surgido a afinidade entre Chateaubriand e Getúlio Vargas. Getúlio se empolgou com a idéia de Chateaubriand criar uma rede de jornais, pois aquilo era parecido com o sonho dele de se ter uma unidade nacional. Com o apoio de Getúlio, ele consegue dinheiro, e, ainda, lança ações de um jornal que nem existe.

Em 1925, O Jornal já é um sucesso. Chateaubriand parte para sua segunda conquista, e compra, em São Paulo, o "Jornal da Noite", por cerca de um terço do valor que lhe foi pedido. Através dos jornais, ele começa a tentar influenciar a opinião pública, de acordo com os próprios interesses.

A primeira campanha que fez através dos jornais foi em apoio à Coluna Prestes. O governo tenta tirá-lo da direção do jornal, assumindo o controle acionário, mas não consegue. 
Casa-se com Maria Henrieta Barrozo do Amaral e lança o livro "Terra desumana" - uma crítica ao governo Artur Bernardes. O presidente ameaçou censurar o livro.

Com a mudança do governo, assume Washington Luís. Chateaubriand aproveita a liberdade e faz campanha para a concessão de anistia aos combatentes da Coluna Prestes.

A paixão de Chateaubriand por Getúlio também pode ter relação com a criação da revista $O$ Cruzeiro. Ele já tinha simpatia por Getúlio antes da sua candidatura. Tenta também quebrar a política do café com leite dos mineiros.

Depois, aumenta sua rede de jornais, com o Diário de São Paulo e jornais no Rio e Minas Gerais (Estado de Minas).

Colocou toda a sua rede de jornais em prol da Aliança Liberal e seu candidato, Getúlio Vargas. A derrota de Getúlio começa a lançar as sementes da revolução de 1930. Chateaubriand se envolve na campanha pela não aceitação do resultado da eleição e começa a ser procurado pela polícia. Em 1930, passa parte do mês de julho na clandestinidade, até ser preso. $\mathrm{Na}$ prisão, recebe o pedido de divórcio da esposa. Quando saiu da prisão, começou a reconstruir seu império. Mas durou pouco tempo, pois após publicar uma matéria pedindo anistia aos exilados, foi emitido um novo mandado de prisão. Ficou três meses no presídio de São Paulo.

Em 1933, aproximou-se de Getúlio e comprou "A Cigarra". Publicou reportagem comemorando um ano da revolução e voltou para a prisão do Paraíso.

Em 1934, nasceu sua filha Teresa Acunha, que não pôde ter o seu nome porque ele não era casado com a mãe dela. Este problema foi resolvido, algum tempo depois, quando Getúlio Vargas tornou-se presidente, e mudou a legislação, permitindo que se pudesse registrar outros filhos fora do casamento.

Chateaubriand, no início dos anos 50 já era conhecido como dono dos Diários Associados.

Estava dividido entre a campanha presidencial, a consolidação do Museu de Arte de São Paulo e a realização do velho sonho de implantar no Brasil a quarta estação de televisão do mundo e a primeira da América Latina. (MORAIS, 1994: 496) 
Mas, na realidade, o projeto da TV Brasileira já estava muito avançado, pois Chateaubriand tinha acabado de chegar dos Estados Unidos, onde entregara a Meade Brunnet e David Sarnoff, diretores da RCA Victor, os 500 mil dólares para pagar a primeira prestação de uma compra total de trinta toneladas de equipamentos, no valor de 5 milhões de dólares.

Quando faltava um mês para a inauguração da TV no Brasil, os dois diretores da TV Tupi, Mario Alderighi e Dermival Costa Lima, entraram em pânico, ao descobrirem que ninguém poderia assistir à emissora. Alertaram Chateaubriand para o fato de que não havia aparelhos receptores no país.

\begin{abstract}
Chateaubriand disse para eles não esquentarem a cabeça com aquilo, que no Brasil tudo tinha solução. Telefonou ao dono de uma grande empresa de importação e exportação e pediu-lhe que trouxesse por avião, dos Estados Unidos, duzentos aparelhos de TV, de modo que chagassem a São Paulo três dias depois. O homem explicou que não era tão simples: por causa da morosa burocracia do Ministério da Fazenda, um processo de importação (mesmo que fosse agilizado por ordem do Presidente da República, como Chateaubriand sugeria) iria consumir pelo menos dois meses, até que os televisores fossem postos no aeroporto de Congonhas. Chateaubriand não se assustou: - Então traga de contrabando. Eu me responsabilizo. O primeiro receptor que desembarcar eu mando entregar no Palácio do Catete, como presente meu para o presidente Dutra (MORAIS, 1994: 500-501).
\end{abstract}

Assis Chateaubriand Bandeira de Melo morreu no dia 04 de abril de 1968, de colapso cardíaco. Durante o funeral, o diretor do Masp e amigo há mais de vinte e cinco anos dele, Pietro Maria Bardi, pendura quatro telas sobre o caixão. No centro, sob a cabeceira do morto, uma tela Renoir, exibindo uma moça nua. À esquerda, o retrato de dois cardeais e à direita, um inquisidor espanhol. Quando o questionaram sobre sua atitude, Bardi simplesmente diz: "esta é a minha última homenagem a Assis Chateaubriand, vero? Nesta parede estão as três coisas que ele mais amou na vida: o poder, a arte e a mulher pelada". (MORAIS, 1994: 695)

Segundo Marques de Melo, Chateaubriand protagonizou o acontecimento que marcou a fisionomia da moderna sociedade brasileira, pois: "A inauguração da TV garantia ao Brasil a precedência sobre os demais países da América Latina no funcionamento de uma emissora destinada a difundir imagens em movimento: informação, entretenimento e anúncios comerciais." (MARQUES DE MELO, 2005: 131) Ele colocou o Brasil como o primeiro país da América Latina a implantar a televisão e, ainda, como o quarto em relação ao mundo. Infelizmente essa visão de Chateubriand não perdurou pelo 
decorrer da história da televisão no país, nem pelos homens que continuaram a fazer a história, porque nos anos 90, o Brasil foi o último na América Latina a implantar a televisão a cabo, perdendo assim a dianteira conseguida por Chatô.

\subsection{Os Primeiros telejornais brasileiros dos anos 50 na Rede Tupi, TV Paulista e Rede Record}

As informações sobre as emissoras e os seus telejornais foram levantadas junto a fontes bibliográficas, os próprios sites das emissoras, alguns sites especializados ou dedicados ao assunto e também junto aos jornalistas que, gentilmente, se dispuseram a participar desta pesquisa. Não se buscou uma verdade absoluta a respeito das emissoras, mas sim contar com um olhar diferenciado um pouco mais deste momento, que faz parte da história das comunicações do país. É importante ressaltar, também, que está pesquisa se ateve às questões relacionadas com o telejornalismo e o telejornalista, por isso, as questões relacionadas com a teledramaturgia, os shows, os programas de variedades e outros gêneros televisivos não foram levados em conta, devido ao recorte específico proposto pelo trabalho.

A inicialmente PRF-3, TV Tupi-Difusora de São Paulo, foi a primeira emissora do Brasil e da América Latina, e a quarta do mundo. Inaugurada em 18 de setembro de 1950, por Assis Chateaubriand, que já era dono dos Diários Associados. A antena da emissora foi instalada no alto da torre do Banco do Estado de São Paulo.

Como naquela época ainda não existiam muitos proprietários de aparelhos de televisão, Chateaubriand instalou, em alguns pontos estratégicos da cidade de São Paulo, aparelhos para que as pessoas pudessem conhecer a novidade que estava propondo ao público. Outra medida para fazer com que o

público se habituasse ao novo veículo de comunicação foi popularizar a televisão, com o apelido de "rádio com imagens" e, ainda, implementar uma 
ampla campanha informativa através das emissoras de rádio e dos jornais das Associadas.

A identificação gráfica da televisão, como quase tudo, veio do rádio. No primeiro momento, o símbolo adotado foi o índio da rádio Tupi. Depois de um tempo, sentiu-se a necessidade de mudar o índio sério por algo que fosse mais leve e ameno. Mário Fanucchi, que pode ser considerado o primeiro diretor de arte da televisão brasileira, e na época era responsável pelas cartelas que abriam e enceravam os programas e transmissões, propôs algo que veio a marcar para sempre a primeira emissora de televisão brasileira: a substituição daquele grande índio sério por um indiozinho pequeno e simpático, com uma antena de televisão na cabeça. Este fato dinamizou a televisão e serviu de base para todas as outras emissoras das Associadas, que foram inauguradas depois, e, também, para as concorrentes. Naquela época, padronizou-se a utilização de um mascote como símbolo, como poderemos observar nas emissoras que vieram depois da Tupi.
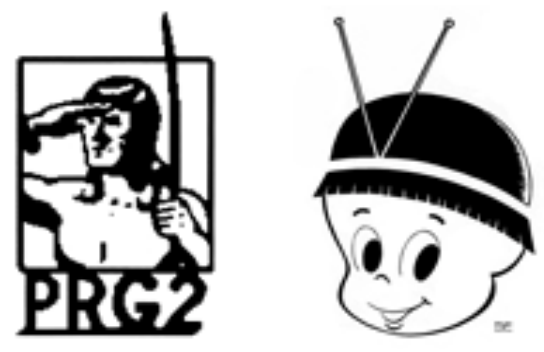

O índio símbolo da Rádio Tupi e o indiozinho criado por Fanucci.

A respeito da primeira transmissão, não existe nenhum registro oficial de vídeo, por isso, fica difícil saber exatamente como ocorreu este momento histórico. Algumas reportagens da época narram histórias diferentes, dependendo do veículo. De acordo com Xavier Apud Pro-TV (www.protv.com.br), no primeiro dia, a tevê Tupi teve a seguinte programação inaugural: às 4 horas da tarde, o bispo auxiliar de São Paulo, dom Paulo Rolim Loureiro abençoou os estúdios e benzeu as câmeras. Depois, Chateaubriand fez um discurso oficial, de acordo com Morais. A solenidade continuou com a 
palavra da madrinha da televisão, a poetisa Rosalina Coelho Lisboa Larragoiti, entre outros convidados a falar na ocasião. A parte oficial terminou às 6 da tarde. Depois, às 21 horas, começaria o show inaugural intitulado TV na Taba, mas, devido a problemas técnicos com uma das três câmeras, que quebrou momentos antes do início, a programação começou com uma hora de atraso com apenas duas das câmeras. A direção foi de Dermival Costa Lima, com assistência de Cassiano Gabus. Na seqüência as atrações que fizeram parte do primeiro dia de programação: a atriz Yara Lins apareceu na telinha, anunciando o prefixo da emissora, depois, segundo depoimento à pró-TV, a atriz mirim Sonia Maria Dorce, com apenas 5 anos, apareceu vestida de índio, dizendo: "Boa noite. Está no ar a televisão do Brasil". Na seqüência, o anfitrião Homero Silva apresentou um desfile das atrações da televisão naquela noite, onde cada um mostrou um pouco do que seria a sua participação no novo veículo. As atrizes Helenita Sanchez e Miriam Simone mostraram um cartaz de Dança Ritual do Fogo e introduziram a orquestra de Georges Henry, com a participação do assoviador William Fourneaux. A Escolinha do Cicilio era o programa humorístico de autoria de Paulo Leblon, com a participação de Xisto Guzzi, Simplício, Walter Avancini, Geni Prado, João Monteiro, Adaísa de Oliveira, Nelson Guedes e Lulu Benencase. O maestro Rafael Pugliese tocou piano. O comediante Mazzaropi mostrou como seria o seu programa Rancho Alegre. $O$ apresentador Aurélio Campos mostrou como seria o programa Vídeo Esportivo. Wilma Bentivegna e os Garotos Vocalistas ou, Os Três Amigos, interpretaram um bolero. A bailarina Lia Marques dançou junto com o cantor Marcos Ayala o Romance Espanhol. Os atores Walter Foster, Lia de Aguiar e Vitória de Almeida encenaram o esquete da comédia conjugal Ministério das Relações Domésticas. O locutor Maurício Loureiro Gama deu uma mostra do que seria o seu Em Dia com a Política. O programa Clube Papai Noel, com crianças exibindo seus dotes artísticos, foi importado da Rádio Difusora para a tevê. Lolita Rodrigues substituiu Hebe Camargo e cantou o Hino da TV. Às $11 \mathrm{e}$ meia da noite, sem qualquer propaganda, terminava o espetáculo TV na Taba. Como se pode perceber, o primeiro dia da televisão no Brasil não teve informação ou telejornalismo, como se convencionou denominar aqui, mas foi só no primeiro dia. A partir do segundo, foi incluído na programação o telejornal. 


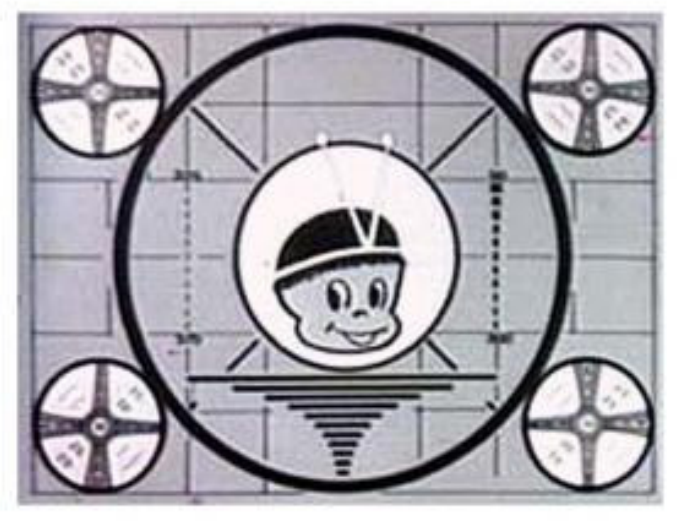

O slide de segurança e de ajustes da TV Tupi.

O primeiro telejornal nasceu praticamente junto com a televisão no Brasil. Imagens do Dia foi ao ar, pela primeira vez, no dia 19 de setembro de 1950, ou seja, um dia depois da inauguração da TV por Chateaubriand. O telejornal tinha um estilo radiofônico, e segundo Paternostro (1999: 35), entrava no ar entre nove e meia e dez horas da noite, mas, segundo Fanucchi (2006), era "transmitido aproximadamente às 23 horas, de segunda a sábado, com cerca de 15 minutos de duração". Já Sampaio, informa que o Imagens do Dia encerrava a programação por volta de nove e meia ou dez horas da noite, e constava de uma seqüência de filmes dos últimos acontecimentos locais (SAMPAIO, 1971: 23). Isto só deixa claro que o primeiro telejornal brasileiro não tinha um horário fixo para entrar no ar. Não existia o que se conhece hoje por instantaneidade ${ }^{14}$.

O jornalista Rui Rezende foi o primeiro apresentador deste telejornal. Ele era locutor, produtor e redator de notícias, que era comum entre os primeiros jornalistas e apresentadores do rádio que foram para a televisão. Ele fazia uma espécie de locução radiofônica sobre as imagens que eram exibidas. A leitura dos textos era feita pelo apresentador, à maneira dos locutores de rádio, com ilustração eventual, através de filme em $16 \mathrm{~mm}$, negativo, com inversão no

\footnotetext{
${ }^{14}$ Instantaneidade, de acordo com Paternostro, é a informação da TV que requer "hora certa" para ser vista e ouvida - a mensagem é momentânea, instantânea. Ela é "captada" de uma só vez, no exato momento em que é emitida. Não tem como "voltar atrás e ver de novo", ao contrário de jornal ou revista (1999: 64). Já Squirra, afirma que pelas suas próprias características técnicas, a televisão proporciona possibilidade de mostrá-lo logo depois de ter acontecido, quase instantaneamente. Em vez de relatar o fato, ela mostra toda a sua dimensão (1993: 51).
} 
telecine, ou com filme reversível processado no laboratório. Haviam mais notas nos telejornais do que reportagens propriamente ditas. $O$ conceito de reportagem ainda não estava desenvolvido na cultura da redação da tevê Tupi.

Um fato interessante aconteceu com o jornalista Maurício Loureiro Gama (que apresentava o seu Em Dia com a Política), um dia depois da sua primeira aparição na televisão, de acordo com o especial 50 anos da TV, da Rede Globo, veiculado em 2000:

\begin{abstract}
Ninguém sabia o que era televisão. Eu logo quando fui convocado para trabalhar na televisão, fui às livrarias para ver se arranjava livros. Não havia literatura nenhuma, nem livro traduzido. Foi uma tragédia. Como é que vamos fazer televisão? Sei lá. No dia seguinte encontrei uma mulher na rua Marconi... e ela me disse: o senhor não é aquele que trabalhou no primeiro programa de televisão ontem a noite? Eu trabalhei. O senhor sabe, eu queria dizer uma coisa pro senhor, o senhor não é antipático o senhor é até simpático pessoalmente. Eu queira dizer uma coisa: - Você é muito arrogante. Eu disse arrogante eu minha senhora, eu sou um caipira de Tatuí, humilde porque eu fui arrogante? Você não falou comigo, não se dirigiu a mim, eu estava fazendo crochêzinho na minha sala. Você poderia ter conversado comigo, me consultado sobre as idéias que estava expondo. Você não consultou nada, você foi em frente falando. Como é que a senhora sabe tanta coisa de televisão? Foi porque eu morrei em Nova lorque. Vi televisão lá. Como aqueles comentaristas fazem. Eu me despedi dela, voltei para o jornal e rasguei o que eu ia ler a noite e fiz os originais como se fosse uma peça de teatro. Então o Chateaubriand telefonou. Eu disse: tava muito ruim. Ele disse: ao contrário, você foi o único que entendeu a televisão. Com quem você aprendeu a fazer televisão? Eu contei a história da mulher. Ele me perguntou como era o nome da mulher? Eu disse: não tomei nota. Lamentável! Lamentável! O senhor merecia ser despedido (GLOBO, 2000).
\end{abstract}

O telejornal Imagens do Dia tinha como redator Gonçalo Parada, com texto produzido na redação dos Diários Associados na Rua 7 de Abril, número 230. Algumas poucas notícias eram produzidas em filme preto e branco, sem som. A produção das imagens, segundo Fanucchi, era em filmes, "em geral 2 minutos e trinta segundos (trinta pés), eram sonorizados no ar, obtidos com câmeras Bell \& Howell, de corda, na mão do cinegrafista." Em alguns casos, especiais, informou Fanucchi, quando era indispensável a sonorização direta, como em falas de autoridades, usava-se a câmera Cine Kodak Special, com motor elétrico, geralmente apoiada em um tripé. O telejornal ficou no ar por cerca de três anos, de acordo com Sampaio, e foi substituído pelo Telenotícias Panair, que entrou no ar em janeiro de 1952. Foi um telejornal pontual, com horário certo para começar, dando início ao que se conhece hoje como 
instantaneidade. Telenotícias Panair era transmitido diariamente, às nove da noite, e era apresentado por Toledo Pereira. Nesta época, nota-se, também, a ampla utilização do merchandising - "que é uma forma de veiculação diferente dos comerciais convencionais. É uma ação que incorpora ao conteúdo do programa a mensagem que se pretende passar ao público telespectador sobre determinado produto ou serviço" ${ }^{15}$, inclusive, neste caso, no nome do telejornal.

Ainda na fase da utilização do merchandising, surge o primeiro telejornal de sucesso da televisão Brasileira, o Repórter Esso. Estreou na TV Tupi de São Paulo, em 17 de junho de 1953. Ficou no ar quase 20 anos, até 1970. Em 31 de dezembro de 1964, o Repórter Esso saiu da TV Tupi e passou a ser exibido na TV Record - Canal 7. Nesta emissora, o telejornal ficou no ar por mais de onze anos. No início, era dirigido e apresentado por Kalil Filho. $\mathrm{O}$ sucesso anterior conseguido pelo similar radiofônico talvez tenha levado ao sucesso da versão com imagens.

Depois de algum tempo, com a expansão da televisão para vários estados brasileiros, em 1951, o Rio de Janeiro ganhou a sua emissora carioca - a tevê Tupi canal 6. A versão carioca do Repórter Esso, com Gontijo Teodoro, surgiu em 1954. Além do nome do patrocinador, o Repórter Esso também tinha horário fixo, sempre às oito da noite. $O$ plano utilizado pelo apresentador era americano e tinha um slogan inconfundível: "Aqui fala o Repórter Esso, testemunha ocular da história."

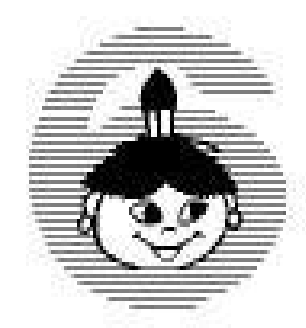

O logotipo da TV Tupi do Rio - canal 6.

\footnotetext{
${ }^{15}$ Manual Básico de Mídia Rede Globo, 2000 : 75.
} 
Quando o Repórter Esso foi para Record e no lugar dele começou o Ultranotícias, que ficou no ar até dezembro de 1970. De acordo com Sampaio, este telejornal manteve a tradição do horário e era, segundo o IBOPE, um dos dez programas de maior audiência da Televisão de São Paulo (SAMPAIO, 1971: 25)

Depois de algum tempo, houve a necessidade de criar um telejornal vespertino, na TV Tupi. Começou o Edição Extra, que era apresentado por Maurício Loureiro Gama. Foi nesse momento que surgiu, também, o primeiro repórter da televisão brasileira, José Carlos de Morais, que ficou muito conhecido como "Tico-tico". O Repórter Esso e o Edição Extra conviviam na mesma emissora em horários distintos. O Repórter Esso tinha estreita ligação com a United Press International, que exercia completo controle sobre seu noticiário. Apresentador, redator, supervisor, todos formavam um grupo independente da equipe de jornalismo da emissora. Já o Edição Extra, era considerado o telejornal "da casa", conforme Fanucchi.

Ainda na década de 50, houve um outro telejornal na TV Tupi, Mappin Movietone, aonde Fanucchi chegou a apresentá-lo no ano de 1953. Ele não pôde precisar exatamente o período que durou este telejornal, mas comentou alguns detalhes daquela época:

Quando fazia o "Mappin Movietone". Aliás, muita gente teve experiência semelhante com a famosa "mosca do estúdio". Naquele tempo, a tinta usada para pintar cenários e painéis de fundo era fixada com ajuda de cola quente, feita à base de chifre derretido. $O$ cheiro dessa cola não era nada agradável, a não ser para as moscas... ainda mais se considerarmos o calor produzido pelo grande número de panelões e refletores exigido pelas câmeras de então. Pois todos os programas só começavam depois que o assistente de estúdio dava umas boas bombadas de inseticida no "set". Mas sempre havia uma maldita mosca que resistia ao ataque e passava a atormentar o pessoal em cena, passeando pelas faces, pelas mãos, pelos objetos que estavam sendo manipulados. Os apresentadores de telejornal sofriam ainda mais, pois eram obrigados a ficar imóveis e com as mãos ocupadas em segurar o script. Um belo dia estava eu começando a ler as notícias quando a mosca entrou em cena. Primeiro, pousou na minha testa; depois, desceu pelo rosto, voltou para testa, foi até o queixo, desceu para o pescoço - enfim, deu um passeio completo. $\mathrm{E}$ eu, suando frio. Eis senão quando, vi no roteiro que ia entrar uma matéria sonorizada. Com o rabo do olho, vi a mosca passando de uma das minhas mãos para a mesa, onde ficou parada, esfregando as patinhas. Não hesitei: no momento da entrada do filme sonoro, certo de que eu estava fora do ar, dobrei o script e mandei um golpe certeiro na 
mosca. De imediato, olhei para o monitor à minha frente ... e me vi cometendo 0 inseticídio. Falha do diretor de imagem, que não conectou o telecine (FANUCCHI, 2006).

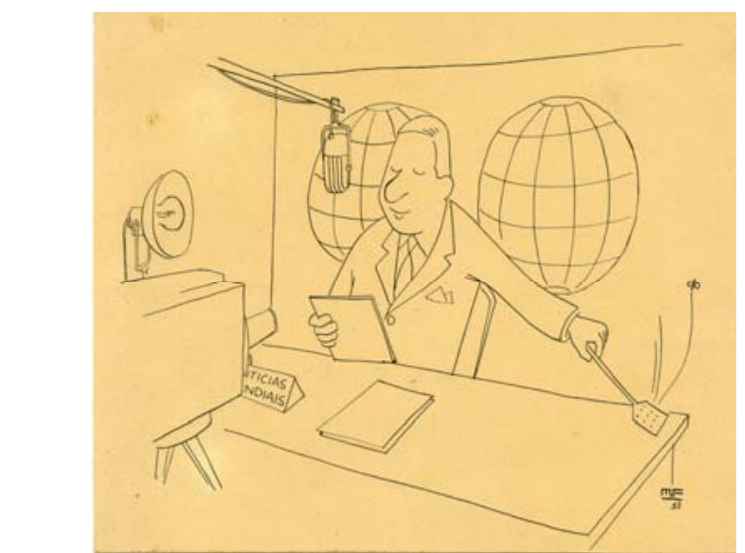

A charge ilustra o momento de tensão do apresentador

Em 01 de agosto de 1960, a Tupi mudou de prefixo, passou a ser sintonizada no canal 4. No mês seguinte, a emissora inaugura, em São Paulo, o edifício-sede no Sumaré. A rede nacional Tupi de televisão é formada em abril de 1974.

Outros programas jornalísticos de destaque da emissora na época, segundo Xavier, foram o Falando Francamente, com Arnaldo Nogueira, Índio não tem Bandeira, com Jair Martins e os debates políticos do Pinga Fogo (1963); o programa experimental Móbile (1964); o jornalístico Abertura (1979) e o apelativo Aqui e Agora (1979).

Em 24 de janeiro de 1980, os funcionários da tevê Tupi de São Paulo iniciaram uma greve devido ao atraso no pagamento dos salários. Eles tiraram os programas do ar. Depois de um mês, os atores foram demitidos.

O jornalista Saulo Gomes (do programa IstoÉ São Paulo), da central paulista da Tupi, encerrou as produções da emissora. As imagens passaram a ser geradas do Rio de Janeiro para os outros estados da rede. Em 16 de julho de 1980, com quase 30 anos de transmissões, a TV Tupi de São Paulo, com mais 6 das 9 emissoras da rede, foi declarada extinta. Ficaram apenas a TV Brasília, do Distrito Federal, e a TV Itapoan, de Salvador. De acordo com Xavier, o fim foi dramático em cada uma das emissoras: 
As últimas imagens da Rede Tupi foram ao ar em 18 de julho de 1980: a TV Itacolomi de Belo Horizonte nem chegou a funcionar naquele dia; a TV Marajoara de Belém encerrou a programação na véspera com o filme Tempos Difíceis; a Rádio Clube do Recife se despediu às $10 \mathrm{~h} 50$ com uma reportagem sobre a sua própria extinção; às $11 \mathrm{~h} 19$ foram lacrados os transmissores da TV Ceará de Fortaleza, após uma série de apelos como o do cantor Fagner; a TV Tupi de São Paulo já se encontrava em greve e foi fechada às 11h30; a TV Piratini de Porto Alegre interrompeu um episódio da série Bonanza às 11h55; e após uma vigília de 18 horas comandada por Jorge Perlingeiro, que varou a madrugada, a Tupi carioca saiu dramaticamente do ar, às $12 \mathrm{~h} 36$, em meio ao choro dos funcionário e um VT da visita do Papa João Paulo II ao Brasil. (XAVIER, 2000)

A TV Tupi foi cassada pelo regime militar. Os motivos alegados foram os problemas financeiros que a emissora enfrentava na época. Outros alegam ter sido a má administração. Não é possível, nos dias de hoje, se chegar a um único motivo. As emissoras da rede foram divididas por dois grupos empresariais - Sílvio Santos e Adolfo Bloch.

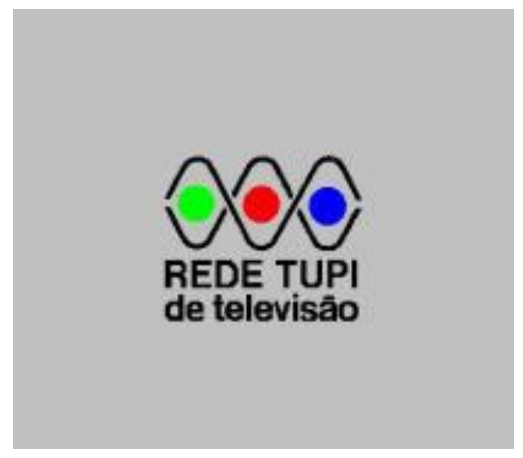

O último logotipo da Tupi

A tevê Paulista foi inaugurada, ou fundada, como preferem alguns historiadores, em 14 de março de 1952. Foi a segunda emissora de televisão de São Paulo e a terceira do Brasil. Seu primeiro destaque no telejornalismo foi com Silveira Sampaio, nos anos 50. Ele conseguia ser intérprete e tradutor, o intermediário entre o fato e o público. Com carreira consagrada no teatro, como autor, diretor e ator, Silveira Sampaio foi considerado um dos maiores entrevistadores da televisão brasileira, na década de 50. O SS Show, pela TV Paulista, Canal 5, marcou época e deixou saudade no público telespectador (SAMAPIO, 1971: 25). A tevê Paulista desafiava a sua maior concorrente, a tevê Tupi, com a sua inovação, que deu origem a dezenas de sucessos. 
Seu proprietário era o Deputado Ortiz Monteiro, que a utilizava para fazer propaganda política. As primeiras instalações da tevê Paulista eram localizadas na Rua da Consolação, quase em frente à Avenida Paulista, no Edifício Liége. Possuía um espaço pequeno e equipamento modesto, se comparada com a pioneira Tupi. Eram quartos de $3 \times 4$ metros, estúdios improvisados, onde existia uma garagem e um espaço para uma loja. A projeção dos filmes era feita na parede de um dos quartos e de lá a câmera gravava. O laboratório de revelação ficava hospedado numa pequena cozinha ao lado do quarto da projeção. A redação jornalística situava-se na sala deste apartamento do quarto andar, onde eram elaboradas as pautas dos programas. O telejornal da emissora era feito por Roberto Corte Real e apresentado e produzido por Mário Mansur. Mas a tevê Paulista tinha um trunfo para superar a líder, era a sua unidade móvel, que era um ônibus de externa.

Em 1955, a tevê Paulista foi comprada pelas Organizações Victor Costa, que detinham, também, a propriedade das Rádios Nacional, em São Paulo (atual Globo) e no Rio de Janeiro (continua Nacional), da Rádio Excelsior (atual CBN) e de outras emissoras de rádio e televisão no interior do país.

Depois da venda, a emissora mudou-se para um prédio de 5 andares na Rua das Palmeiras. Vieram se juntar ao time a tevê Paulista, tendo como diretor geral Dermival Costa Lima, oriundo da Tupi. Alguns programas e comunicadores, que iniciaram na Paulista, ainda hoje, estão no ar, como a primeira versão da Praça de Alegria, lançado por Manuel da Nóbrega e o Programa Silvio Santos, que bate o recorde de permanência no ar, tendo sido apresentado em diversas emissoras como Globo, Record e, atualmente, no SBT.

A TV Paulista também se destacou no gênero entrevista, com $O$ Mundo é das Mulheres, com Hebe Camargo. Outro destaque foi o Câmera Um, com Jacy Campos. Teve ainda o Preto no Branco, com criação e produção de Fernando Barbosa Lima e apresentação de Oswaldo Sargentelli.

Nesta época, a tevê Paulista possuía como símbolo um globo terrestre, que era apelidado pelos profissionais da emissora de "mundinho". Não se 
imaginava, conforme veremos mais à frente, que chegaria a ser o que se conhece hoje como a tevê Globo.

Em 1960, a emissora entrou em crise, quando Victor Costa morreu e os filhos não souberam administrar a mesma. Em 24 de março de 1966, foi comprada pelo Sistema Globo de Rádio e Televisão, pois o jornalista Roberto Marinho havia ganhado a concessão do canal 4 do Rio de Janeiro e precisava de uma emissora em São Paulo para formar a sua rede. O nome tevê Paulista foi utilizado pelo Globo até 1968, quando houve um incêndio nas instalações da Rua das Palmeiras, e a emissora resolveu centralizar suas produções no Rio de Janeiro e começar do zero, pois havia sido queimado todo o acervo e a história da tevê Paulista. Nessa época, os estúdios de São Paulo passaram a funcionar todos no prédio da Globo, na Praça Marechal Deodoro.

O nome tevê Paulista, atualmente é de posse autoral do apresentador Augusto Liberato, mais conhecido como Gugu, do SBT. O objetivo dele é usar a marca da antiga emissora para montar a sua própria rede de televisão, que ainda é um sonho, em termos de concessão.

A única referência que pode ser considerada uma herança da tevê Paulista na programação atual da Rede Globo é o título Corujão, usado para filmes na madrugada, que era chamado de Sessão Coruja.

Até o ano de 2005, segundo Romério Costa Machado, tramitava na

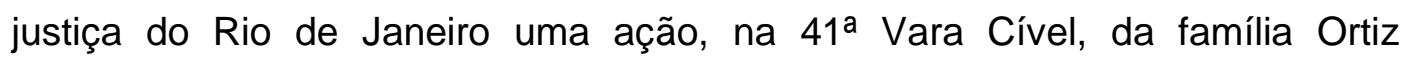
Monteiro contra o espólio de Roberto Marinho com o objetivo de retomar o controle da antiga tevê Paulista (hoje tevê Globo de São Paulo, que é responsável por mais $50 \%$ do faturamento da rede). Os herdeiros da família Ortiz Monteiro alegam que Roberto Marinho assumiu o controle da emissora utilizando documentos falsificados. De acordo com instituto Del Picchia, contratado para fazer a perícia dos documentos, foram constatadas diversas fraudes e falsificações, dentre elas:

-Uso de CPF nos documentos de transação da venda do controle acionário (procurações e substabelecimentos) entre 1953 e 1964, quando o CPF não existia e só passou a existir a partir de 1970. 
-Cerca de 650 acionistas "mortos" ou não localizados transferiram (depois de mortos) ações para Roberto Marinho pela assembléia de 30 de junho de 1976. Entre os "mortos" ou desaparecidos estão pessoas conhecidíssimas (vivas) como: Oscar Americano, José Ermírio de Morais, Antônio Silvio Bueno, Bento do Amaral Gurgel, Vicente Amato Sobrinho, Romeu Trussardi e Sylvio Bueno Vidigal.

- Recibo de 05 de dezembro de 1964 foi adulterado para 23 de julho de 1975.

- Em 23/07/75, o recibo em nome da Rádio Televisão Paulista S/A é falso, pois em 75 esta empresa já não existia, pois tinha sido substituída em 1973 pela TV Globo São Paulo S/A.

- O valor nominal de cada ação deveria ser de $\operatorname{Cr} \$ 1,00$ (hum cruzeiro) e não Cr\$1.000,00 (hum mil cruzeiros), pois em 1967 a moeda era cruzeiro novo e não tinha três zeros.

- Manoel Vicente da Costa, falecido em 15 de dezembro de 1964 não poderia deixar uma procuração com data futura, posterior à sua morte, para negociar ações.

- Idem Hernane Ortiz Monteiro.

-Manoel Bento da Costa, que aparece como titular de duas mil ações, jamais existiu.

-Os documentos datados de 1953 a 1964 foram datilografados na mesma máquina, Olivetti, que só passou a existir na década seguinte, de 70 (aliás, em todos os documentos adulterados batia a letra "a" de forma irregular)

-A procuração falsa de Luiz Eduardo Borgerth é tão falsa, que é datada de uma época que ele ainda era menor de idade. (http://www.fazendomedia.com/globo40/romero7.htm - acesso em 17 de outubro de 2008)

Para Machado, os advogados do espólio mudaram a versão dos fatos para não aceitar a hipótese de que Roberto Marinho falsificou documentos. Eles sustentam que Roberto Marinho não comprara a emissora dos irmãos Ortiz Monteiro, e sim, de Victor Costa Petraglia Geraldine Júnior, que era o herdeiro de Victor Costa, que por sua vez, teria adquirido a emissora em 1955, da família Ortiz Monteiro. Na realidade, legalmente, Victor Costa jamais foi dono oficial da tevê Paulista, porque havia firmado com os irmãos Ortiz Monteiro apenas um contrato condicionado, que teria que ser aprovado pelo Ministério das Comunicações e isso não aconteceu. Outra manobra dos advogados para inviabilizar o processo foi o pedido para aumentar o valor da causa de 20 mil reais para 80 milhões, de modo que os herdeiros de Ortiz Monteiro não pudessem pagar as custas judiciais, que são proporcionais ao valor da causa. A última criação dos advogados do espólio de Roberto 
Marinho para justificar a legitimidade do controle acionário da tevê Paulista foi apelar para que o judiciário reconheça uma espécie de "usucapião acionário", pois segundo eles: "ainda que se queira desconsiderar todos esses negócios e documentos, não há como fugir da constatação de que, de todo modo, Roberto Marinho teria se tornado delas (ações vertentes) proprietário ad usucapionem."

O último desdobramento do caso aconteceu em 2005, quando o juiz da 41 - Vara Cível, Leandro Ribeiro da Silva, após ter fracassado na busca de um acordo entre as partes, declarou-se suspeito para julgar a ação, em decorrência de uma amizade com um dos advogados envolvidos. Por isso, o processo foi encaminhado ao juiz da $42^{\mathrm{a}}$ Vara. De acordo com Machado, os advogados de Roberto Marinho ofereceram 80 milhões aos representantes dos espólios de Manoel Vicente da Costa e Hernani Junqueira Ortiz Monteiro para desistirem e abafar a ação contra os dirigentes da Globo, pelas fraudes na compra da Rádio TV Paulista S/A, hoje TV Globo São Paulo.

A tevê Record de São Paulo, canal 7, foi inaugurada às 20 horas do dia 27 de setembro de 1953. A primeira exibição foi de um programa musical, apresentado por Sandra Amaral e Hélio Ansaldo. A emissora da família Machado de Carvalho chegava equipada com a tecnologia mais avançada da época. De acordo com Xavier, a estação foi montada num prédio adaptado, no bairro de Congonhas. O projeto da televisão começou a se tornar realidade três anos antes, pois a concessão foi obtida em 21 de novembro de 1950. A emissora era administrada pelos filhos de Paulo Machado de Carvalho com a seguinte subdivisão: Paulinho, na direção artística, Alfredo, no departamento comercial e Antônio Augusto Amaral - o Tuta, na produção e no setor técnico.

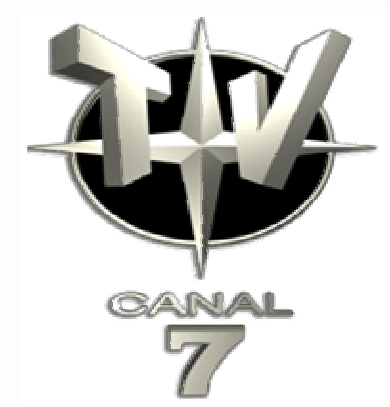

O primeiro logotipo da emissora 
O primeiro telejornal diário foi Estado de São Paulo. Também teve destaque o boletim local Nossa Cidade, com Nicolau Tuma. A emissora investiu em telejornais, mas a programação esportiva ganhou maior destaque. Programas, como Mesa Redonda, criado em 1954 e apresentado por Geraldo José de Almeida, ajudaram a fazer escola na televisão. Já nesta época, a emissora foi pioneira na transmissão, ao vivo, de partidas de futebol. Outros eventos esportivos que aconteciam em São Paulo, como campeonatos de Pugilismo, também eram transmitidos. Em 1956, a tevê Record foi a primeira a transmitir o Grande Prêmio de Turfe do Brasil, do Jóquei Clube do Rio de Janeiro.

A partir de 1966, a emissora foi impulsionada pela promoção de Festivais de MPB, com cantores de sucesso, como Nara leão, Chico Buarque e Caetano Veloso, entre outros. Depois vieram programas de Bossa Nova e a presença da Jovem Guarda, que completaram o sucesso da emissora.

Neste período, formou-se a rede das Emissoras Unidas, com os canais de televisão Record, TV Rio e TV Alvorada de Brasília. No final dos anos 60, a emissora entrou em decadência, depois de uma sucessão de incêndios, que destruiram auditórios, equipamentos e instalações. A programação da Record passou a ser composta de esportes, jornalismo e filmes enlatados.

Nos anos 70, a família Machado de Carvalho começou a vender ações ao empresário e comunicador Sílvio Santos. Com a injeção de capital e a chegada de uma nova geração de dirigentes, a emissora teve uma reação.

Nesta década, em termos de jornalismo, o destaque se deu com o programa Dia $D$, que mostrava entrevistas com personalidades e reportagens especiais. Também são dessa época o Jornal do Rei, que tinha transmissão simultânea entre São Paulo e Rio de Janeiro e o Jornal da Record, que depois passou a se chamar Jornal da Noite. O jornalista Hélio Ansaldo estreou, em 1972, o telejornal Tempo de Notícias, que além de informar, debatia os temas atuais com a participação de especialistas. Alguns anos depois, o nome do telejornal muda para Record em Notícias e a apresentação é de Murilo Antunes Alves, até 1996, que também ficou conhecido como "jornal da tosse", devido à 
tosse que um dos comentaristas apresentava, no ar, e pela idade avançada deles.

No dia 19 de fevereiro de 1972, foi realizada a primeira transmissão em cores da emissora. As imagens foram geradas pela TV Difusora, de Porto Alegre, que exibiu a Festa da Uva, na cidade de Caxias do Sul.

A cobertura esportiva inovou, com três novos programas; o primeiro, $O$ Melhor do Jogo, com Randal Juliano, que mostrava lances do Campeonato Paulista; o segundo era o Desafio do Galo, que abriu espaço para o futebol de várzea, e o Cartão Vermelho, que era uma mesa redonda, com a participação de cronistas especializados. Em 1977, a novidade esportiva é a contratação de Sílvio Luiz, com o De Olho no Lance, um debate transmitido em cores.
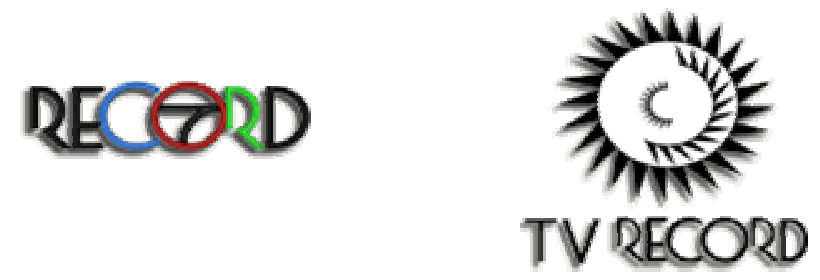

Os logotipos usados nos anos 70

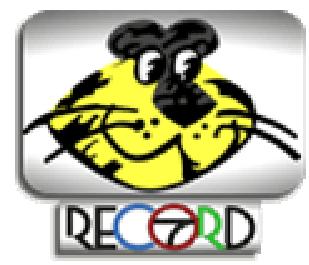

Com a chegada dos anos 80 e do movimento feminista no mundo inteiro, a emissora passa, também, a investir no segmento. Estréia, em 1983, o programa feminino A Mulher dá o Recado, que depois passou a chamar Nova Mulher, apresentado pela jornalista Beth Russo.

A renovação se dá com a contratação do jornalista Danti Matiussi, que assume a direção de jornalismo e coloca no ar o Jornal da Record, comandado por Paulo Markun e Silvia Poppovic. Depois de um tempo, o telejornal passou a ser apresentado por Carlos Nascimento.

Nos anos 80, a TVS do Rio de Janeiro, junto com a Record de São Paulo, iniciaram a construção de uma nova emissora, o SBT, que ocupou a vice-liderança de audiência. A chegada do sinal da tevê Record ao Rio de Janeiro aconteceu em 3 de abril de 1982. Nesta fase, Sílvio Santos, que chegou a ser acionista majoritário da rede, abandonou a sociedade, em 1989. 

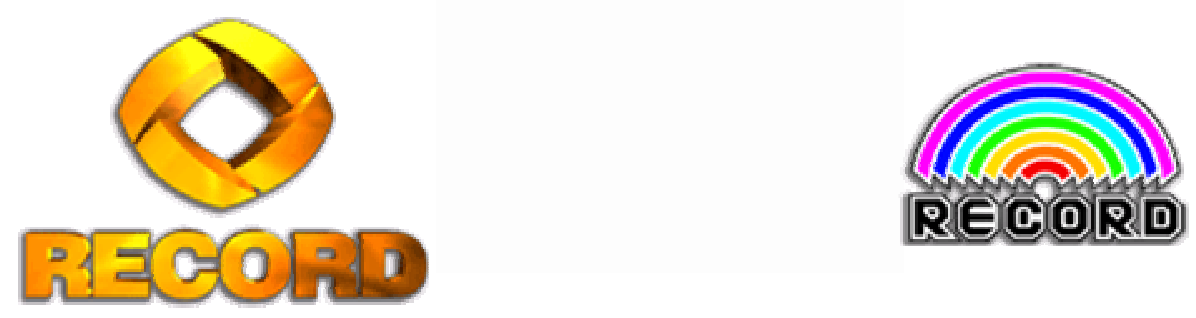

Os logotipos usados nos anos 80

A jornada de Edir Macedo pela compra da Record começou em 1989. De acordo com Tavolaro, os proprietários eram o empresário e apresentador Silvio Santos e a família Machado de Carvalho. A emissora faturava 2,5 milhões de dólares por ano e acumulava 20 milhões de dólares em contas a pagar. Além de Macedo, haviam vários interessados na compra da emissora, como o grupos Televisa, o Jornal do Brasil, o grupo Abril, o empresário do ensino Edevaldo Alves da Silva, o ex-governador de São Paulo Orestes Quércia e o empresário Alberto Felipe Haddad. Mas Edir Macedo não apareceu como comprador, foi representado pelo ex-deputado federal Laprovita Vieira. Para o pagamento da emissora, foi dado um sinal de 7 milhões de dólares, correspondentes à metade da entrada. Outros 7 milhões deveriam ser pagos em 45 dias. Os outros 31 milhões, seriam pagos à família Machado de Carvalho e a Silvio Santos, ao longo de dois anos. De acordo com Tavolaro, a transação entrou para a história, como o maior negócio no setor de comunicações do país, até então. Entre 1990 e 1991, a emissora é comprada pelo Bispo Edir Macedo, por US\$ 45 milhões, quando a mesma já havia perdido o brilho e o glamour daquela programação do passado. Para reverter a situação, ele amplia a sua programação, colocando o jornalismo como carrochefe. Iniciou-se, também, a formação de uma rede nacional de emissoras. A concessão da Record ao Bispo Macedo foi o último ato de Collor na presidência da República, em 30 de setembro de 1992.

Em 1995, a sede da emissora mudou-se para o bairro da Barra Funda. Neste mesmo ano, estreou o telejornal comunitário Cidade Alerta, com o jornalista José Luís Datena, que foi, desde o início, um sucesso do jornalismo popular. No ano seguinte, a emissora se consolida como o terceiro lugar em audiência e passa a disputar o segundo lugar, que até então, pertencia ao SBT. 
Para consolidar seu objetivo, a emissora lança o slogan Rede Record, a nova força do esporte. Mas é só em 1996, com a cobertura dos Jogos Olímpicos, em Atlanta, que marcaria o espaço conquistado pelo esporte na programação. Em 1997, com o final do jornalismo do SBT, o jornalista Boris Casoy reforçou o jornalismo com a sua seriedade, imparcialidade e opinião. $O$ jornalista foi demitido em 2006, por motivos pouco explicados pela emissora. Por um lado, fala-se numa pressão do governo do PT, devido aos comentários ácidos proferidos pelo mesmo ao governo federal, e, por outro, que ele havia se recusado a dividir a bancada com uma apresentadora, para a formação de uma dupla de apresentadores.

O ano de 1998 foi um marco para consolidar a produção jornalística da emissora. Começou com a cobertura da Copa do Mundo e continuou com o lançamento do telejornal Fala Brasil, no período da manhã, e, também, do programa de grandes reportagens Repórter Record. $\mathrm{O}$ ano foi fechado com chave de ouro para o jornalismo, com a compra da primeira unidade móvel totalmente digital: um caminhão com quatro câmeras, um switcher e três aparelhos de edição vídeo-tape, com slow-motion. Com o objetivo de remodelação do setor de jornalismo e para a implantação de uma cobertura internacional, com correspondentes, foi contratado para dirigir o setor 0 jornalista José Luiz Gonzaga Mineiro.
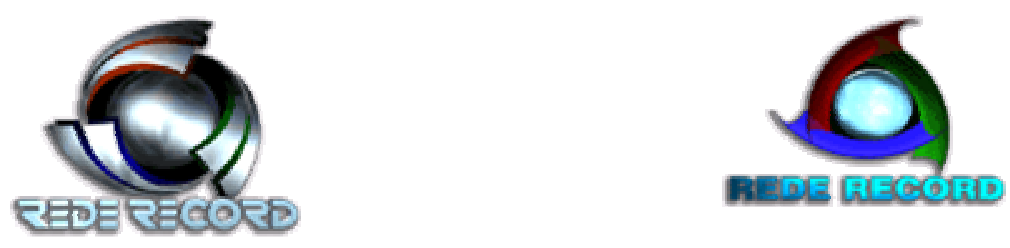

Os logotipos dos anos 90

Em 2001, o esporte ganhou com a contratação de Milton Neves, que lançou dois programas: o Terceiro Tempo - aos domingos à noite e o Debate Bola, no ar, todas as tardes, com discussões sobre futebol. No ano seguinte, quem passa a integrar a equipe de jornalismo da emissora é o jornalista Paulo 
Henrique Amorin, com o quadro Conversa Afiada, dentro do Jornal da Record $2^{a}$ Edição e, também, do Fala Brasil.

Em 2003, a Record completa 50 anos. Ela é a emissora mais antiga em operação no país. Neste mesmo ano, com a saída de Datena, quem assume por alguns meses a apresentação do Cidade Alerta são Milton Neves e Oscar Roberto Godoy. Na seqüência, é contratado para assumir o telejornal o jornalista Marcelo Rezende. No mesmo ano, entra no ar a revista semanal Domingo Espetacular, com apresentação de Celso Freitas, Lorena Calábria e Amália Rocha e, também, o programa jornalístico Tudo a Ver, com Paulo Henrique Amorin e Janine Borba (que, depois, é substituída por Patrícia Maldonado).

O ano de 2005 é marcado pela consolidação da emissora na viceliderança, no horário nobre. Com este fato, a emissora passa a investir mais em jornalismo. Uma das medidas é a contratação do jornalista Britto Júnior, junto com a modelo Ana Hickmann e o Chef Eduardo Guedes, para a apresentação do programa Hoje em Dia. No final deste ano, foi exibida pela emissora uma série de três programas com o tema Fim dos Tempos, onde repórteres da Record percorreram, de acordo com o site dela, os quatro cantos do mundo, para mostrar os dramas da humanidade e os avanços da ciência que levantam questionamentos éticos. A série contou com efeitos especiais, que simularam grandes catástrofes nas metrópoles da atualidade.

Em 2006, o novo Jornal da Record, sem Boris Casoy, passa a ser apresentado por uma dupla: Celso Freitas e Janine Borba. Entra no ar um novo telejornal, no final da noite: Jornal 24 Horas.

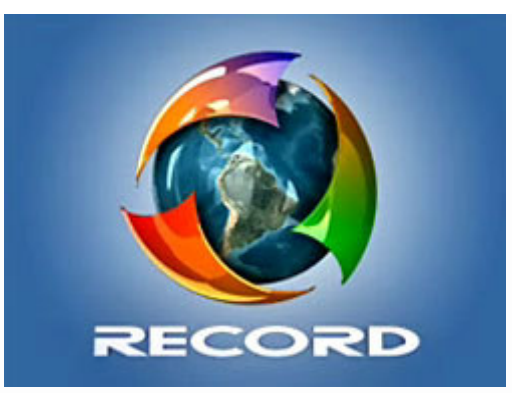

O logotipo atual da emissora. 


\section{2 - Os telejornais dos anos 60: Rede Excelsior, Rede Globo e TV Bauru}

A TV Excelsior, Canal 9 de São Paulo, foi inaugurada no dia 9 de julho de 1960 - dia da Revolução Constitucionalista (o mesmo dia do número do canal). Apresentou algo de novo no setor telejornalístico, com o Show de Notícias, que valorizou a presença da mulher apresentadora de notícias. Propôs, também, uma experiência nova em matéria de redação, com "apresentação, introduzindo o 'corte' rápido e a adequação do texto ao tipo e às potencialidades de cada apresentador" (SAMPAIO, 1971: 25). Era dirigido pelo jornalista Fernando Pacheco Jordão e ficou no ar de 1963 até 1964. Outro telejornal exibido pela emissora foi o Jornal da Cidade.

A concessão da Excelsior era de propriedade da rádio de mesmo nome, que por sua vez estava nas mãos da Organização Victor Costa. Como o grupo estava endividado, vendeu a concessão ao grupo empresarial composto por Wallace Simonsen, o deputado federal Ortiz Monteiro, o exportador de café José Luiz Moura e os donos do Correio Paulistano, João Scantimburgo e Paulo Uchoa de Oliveira.

A emissora estava instalada na Rua Nestor Pestana, 196, em São Paulo, e utilizava equipamentos da Marconi. A gravação e a transmissão dos shows eram realizadas no Teatro Cultura Artística.

A direção da emissora ficou a cargo de Wallace Cochrane Simonsen Netto, mais conhecido como Wallinho, que foi considerada a primeira administração com visão empresarial, pois os funcionários recebiam salários mais justos.

A grade vertical e horizontal, através de uma seqüência com programa infantil, novela, telejornal, show e filme, a cada dia da semana, em dezembro de 1962, acostumando o telespectador a uma programação bem definida, em horários determinados, levou a emissora a alcançar o 1ํ lugar de audiência. Neste período, surgiu o mascote do canal - um casal de bonequinhos 
animados: A Ritinha e o Paulinho (a exemplo do que já havia ocorrido na década anterior com o indiozinho da Tupi, como mascote da emissora).

Em 1963, com a criação da Excelsior, também no Rio de Janeiro, é criado o Jornal da Excelsior, que depois passou a chamar Jornal de Vanguarda. Pouco tempo depois, a pedido do governo, o telejornal, que apresentava uma visão muito crítica para o período, foi tirado do ar, passando para várias outras emissoras, como Tupi, Globo, Continental e Rio. Em 1968, saiu do ar, definitivamente, devido à decretação do Al-5. Criado pelo jornalista Fernando Barbosa Lima, o Jornal de Vanguarda era apresentado por vários locutores e comentaristas. Tinha um visual dinâmico e um jornalismo que abandonava o estilo radiofônico.

De acordo com Xavier, no Rio de Janeiro, em maio de 1963, o diretor Ricardo Amaral contratou quase todo o elenco da TV Rio, pagando ótimos salários. A inauguração da Excelsior carioca aconteceu no dia 1ำ de setembro de 1963. A emissora carioca entrou no ar, através do canal 2 (comprado dos Associados de Chateaubriand, que pretendia lançar a TV Mayrink Veiga), com sede na Avenida Venezuela, número 23, no centro.

A rede Excelsior contou com parcerias, em Porto Alegre, com a tevê Gaúcha - canal 12 e em Belo Horizonte - TV Vila Rica canal 7. Mas isso não foi suficiente para mantê-la no ar, pois mesmo sendo uma das maiores fortunas do país, Mário Wallace Simonsen começou a perder força antes do golpe militar de 1964. Primeiro Simonsen viu seus negócios com café serem boicotados e investigados por uma $\mathrm{CPI}$, porque manifestou-se favorável à democracia e à liberdade de expressão. Depois, a sua companhia aérea Panair fechou as portas. Por fim, em crise e perseguido pelo governo militar, Simonsen passou as ações da TV Excelsior para o grupo Saad e Leite. Estes as transferiram para o grupo Frical (Otávio Frias de Oliveira e Carlos Caldeira Filho - donos da Folha de São Paulo). Simonsen morreu em 1965 e seu filho Wallinho comprou a TV de volta e formou um grupo na própria televisão, para gerir os negócios. Em 10 de julho de 1967, a emissora inaugurou os novos estúdios na Rua Santa Veloso, na Vila Guilherme, em São Paulo (atualmente de posse do SBT), mas como acumulara uma dívida alta junto às distribuidoras 
de filmes, foi vendida para o canal 9 tevê Paulista. A tevê Excelsior do Rio saiu do ar no início de 1970, devido ao pedido de demissão de 70 dos seus 71 técnicos, por falta de salários, por 3 meses.

Ao completar dez anos, as TVs Excelsior de São Paulo e do Rio foram as primeiras do país a terem suas concessões cassadas pelo governo militar, em 30 de setembro de 1970.

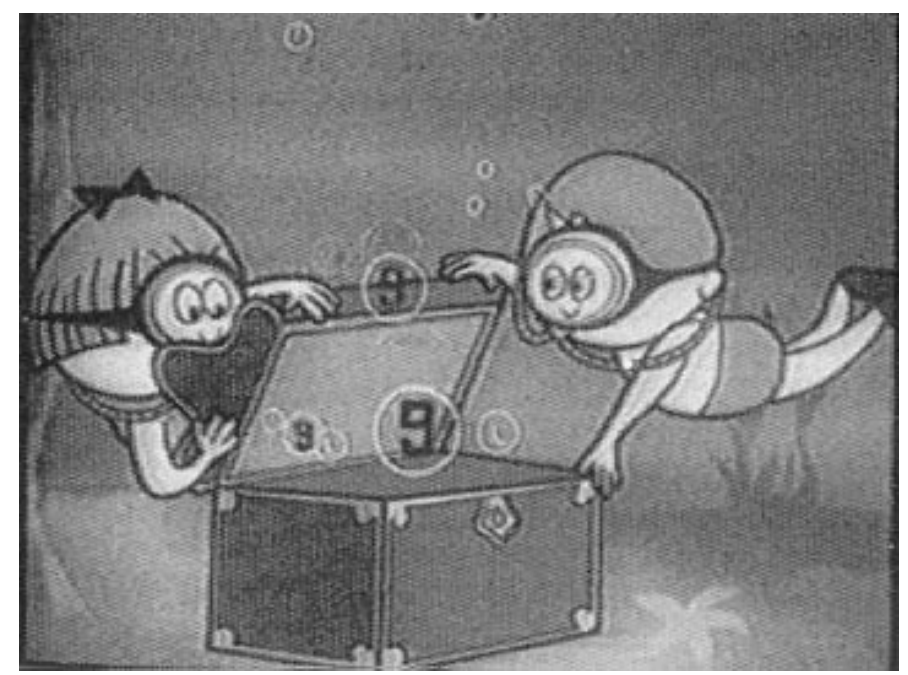

Os mascotes da tevê Excelsior Ritinha e Paulinho na vinheta da emissora.

A ZYD-81 - TV Globo foi inaugurada em 26 de abril de 1965, às $10 \mathrm{~h} 45$ da manhã, sem nenhum festejo ou cerimônia oficial. Criada pelo jornalista Roberto Marinho e associada ao grupo norte-americano Time-Life, a emissora implanta um esquema de network, comprando ou contratando emissoras afiliadas pelo país, para expandir o seu sinal (PATERNOSTRO, 1999: 31). A sede da emissora foi construída na Rua Von Martius, número 22, no Bairro do Jardim Botânico no Rio de Janeiro, local onde antes havia o campo de futebol do Carioca Futebol Clube.

Dois dias antes da inauguração oficial da emissora, houve uma simulação da programação, onde estiveram presentes, além de Roberto Marinho, o governador do Estado do Rio, Carlos Lacerda e o cardeal Jaime de Barros Corrêa, entre outros convidados. Outro teste de programação aconteceu no dia seguinte, em circuito fechado, e foi considerado um desastre. 
De acordo com Xavier, a concessão do canal foi pedida pelo jornalista Roberto Marinho no início da década de 50, mas só foi outorgada pelo governo do presidente Juscelino Kubischek, através de um decreto em 30 de dezembro de 1957. O projeto demorou 8 anos para se concretizar e só foi viabilizado devido aos contratos firmados em 24 de agosto de 1962, com o grupo norteamericano Time-Life. O primeiro, segundo Heiz, denominado Contrato Principal, era uma conta de participação - uma joint-venture. O segundo era um Acordo de Assistência Técnica que tinha algumas de suas cláusulas vinculadas ao Contrato principal. Na época, os contratos assinados pela Rede Globo violaram o Código Brasileiro de Telecomunicações - Lei 4.117 de 27/08/62 e o Regulamentos de Serviços da Radiodifusão - Decreto 52.795 de 31/10/63. O Regulamento, em seu artigo 28 , § $2 \mathrm{P}$ diz que nas: "Cláusulas que acompanham o decreto de concessão para a execução. Dos serviços que o Governo julgue conveniente aos interesses nacionais, deverão estipular: (...) II - proibição de ser firmado qualquer convênio, acordo ou ajuste, relativo à utilização das freqüências consignadas à exploração do serviço, como outras empresas ou pessoas, sem prévia autorização do Conselho Nacional Telecomunicações". Mesmo que a assinatura dos contratos destes documentos fosse um pouco anterior à vigência da Lei e do Decreto, a Globo teria que adaptá-las às suas disposições. Somente três anos depois, em 1965, é que o Conselho Nacional de Telecomunicações tomaria conhecimento destes documentos. Isso não impediu que a Rede Globo recebesse a assistência técnica prevista nos contratos e milhões de dólares, enviados sem nenhuma justificativa contratual. Antes mesmo da assinatura dos contratos, a Globo Ltda, com apenas um mês de vida, recebeu US\$1,5 milhões de dólares de Time-Life Imc. No dia 23 de outubro de 1965, é pedida a criação a Comissão Parlamentar de Inquérito Globo/Time-Life, através de um requerimento publicado no Diário oficial e assinado por 141 deputados, onde a referida comissão deveria "apurar os fatos relacionados com a organização Rádio, TV e Jornal O Globo com as empresas estrangeiras dirigentes das revistas Time e Time Life". Só em 30 de março de 1966, foi criada oficialmente a CPI que investigou as ligações da Organização Globo com o grupo norte-americano Time-Life. Depois de inúmeros depoimentos e solicitações de documentos, em 22 de agosto de 1966, a Comissão Parlamentar de Inquérito que investigou as ligações da Rede 
Globo com o grupo norte-americano Time-Life aprovou, por unamidade,o parecer do relator Djalma Marinho, que apresentou as seguintes conclusões:

$\left.1^{\circ}\right)$ os contratos firmados entre TV Globo e Time-Life ferem o artigo 160 da Constituição, porque uma empresa estrangeira não pode participar da orientação intelectual e administrativa de sociedade concessionária de canal de televisão; por isso sugere-se ao Poder Executivo aplicar à empresa faltosa a punição legal pela infringência daquele dispositivo constitucional; 2o) Deve ser remetida ao Poder Executivo cópia autêntica dos autos desta Comissão de Inquérito, para comprovação das providências sugeridas; 3ำ A mesa da Câmara dos deputados criará, nos termos do regimento Interno, uma Comissão Especial, interpartidária, para elaborar legislação específica sobre televisão (incluindo também rádio e jornal), para preservar a sua nacionalização, dada a presença de capitais estrangeiros nas organizações que explorem essa atividade.(HERZ, 1987)

Num exame detalhado do período de implantação da Rede Globo, realizado por Heiz (A história secreta da rede Globo "SIM EU SOU O PODER" Roberto Marinho), situado entre 1961 e 1968, é possível identificar uma nova fase de renovação tecnológica dos meios de comunicação de massa no Brasil e, ainda, acompanhar detalhadamente todos os passos resumidamente apresentados sobre a tevê Globo.

No primeiro ano, o telejornalismo foi dirigido por Mauro Salles. O primeiro telejornal foi o Teleglobo. Outro programa jornalístico da época foi o Se a Cidade Contasse. O telejornal Ultra Notícias tinha apenas 12 minutos de duração.

Em 1966, com chegada de Armando Nogueira à emissora, começou a ser montada a Central Globo de Jornalismo, com emissoras afiliadas, em todo o país.

A segunda emissora do grupo foi a tevê Globo de São Paulo - canal 5, com sede na Rua das Palmeiras, número 322. A emissora, cuja polêmica já foi colocada anteriormente, quando tratou-se da tevê Paulista, funcionou desde 1952 e foi comprada por Roberto Marinho no final dos anos 60. A integração da tevê Paulista à rede só aconteceu em 5 de fevereiro de 1968, com a inauguração de uma nova torre de transmissão, no Pico do Jaraguá. 
Em 28 de fevereiro de 1969, a emissora realizou a primeira transmissão via satélite do país, com a inauguração da estação terrestre Tanguá, que foi narrada pelo locutor esportivo Hilton Gomes, de acordo com Xavier. Já Paternostro (1999; 26), informa que a primeira transmissão via satélite, ao vivo, foi o lançamento da Apolo IX, em 3 de março de 1969. Cinco meses depois, outra transmissão via satélite aconteceu, no dia 20 de julho, através de uma parceria entre as tevês Globo e Tupi, os brasileiros puderam ver a chegada do homem à Lua. A narração foi dos locutores Gontijo Teodoro, Heron Domingues, Hilton Gomes e Rubens Amaral.

Outra aquisição de Roberto Marinho ocorreu em 1967, com a compra do canal 12 de Belo Horizonte, do grupo João Batista do Amaral. O objetivo de formar uma grande rede era lançar o primeiro programa em cadeia nacional, o que aconteceu no dia $1^{\circ}$ de setembro de 1969 , com a criação do Jornal Nacional, feito no Rio e retransmitido ao vivo, via Embratel, para as emissoras da rede.

Em 21 de abril de 1971, a rede foi estendida para Brasília, através do canal 10. Depois, foi a vez do Recife receber as imagens da rede, através do canal 13, a partir de 21 de abril de 1972. Aos poucos, foram sendo incorporadas outras emissoras próprias e, também, as afiliadas, e, hoje, a emissora cobre $99,9 \%$ do território nacional.

Atualmente, é o telejornal que está há mais tempo ar, cerca de 37 anos. Foi criado por uma equipe comandada pelos jornalistas Armando Nogueira e Alice Maria. Trouxe várias inovações para o telejornalismo, como apresentar reportagens em cores, mostrar imagens via satélite. $O$ estilo de linguagem narrativa e a figura do repórter de vídeo foram copiados do modelo americano. Nos anos 90, a emissora retirou do ar os apresentadores e colocou jornalistas formados na função de editores- âncoras.

De acordo com Mello e Souza, a versão de que o Jornal Nacional teve este nome devido ao patrocínio do Banco Nacional é falsa; segundo ele: "Esse patrocínio veio meses depois de o "Jornal" já estar praticamente consagrado. Foi também uma iniciativa do Comercial, que encontrou forte oposição por 
parte de Armando Nogueira". O Jornal Nacional foi uma cópia do que já existia nos Estados Unidos, mas a sua execução só foi possível devido a inauguração, pela Embratel, do denominado tronco sul, que foi capaz de integrar o Rio de Janeiro, São Paulo, Porto Alegre e Curitiba. O novo telejornal tinha uma preocupação de ser diferente do seu concorrente, o Repórter Esso, e, com isso, criou uma estrutura onde a manchete principal fosse exibida no final do jornal, de uma forma bem mais apurada para conduzir, no retorno ao apresentador a um "boa noite" que fosse tranqüilizador. Essa fórmula animadora de encerar o telejornal prevaleceu até o final dos anos 80 . O Jornal Nacional protagonizou, também, a primeira entrada ao vivo de um repórter. $\mathrm{O}$ fato aconteceu em junho de 1977 e a repórter que protagonizou o evento foi Glória Maria, em condições adversas, pois a iluminação pifou e ela teve que fazer a sua entrada praticamente deitada no chão, para ser iluminada pelo farol da viatura da reportagem.

Nos anos 80 , a emissora buscou fazer do $\mathrm{JN}$ um telejornal manchetado, mas encontrou grandes dificuldades para encontrar uma linguagem apropriada aos tempos da abertura política que o país vivia. Os jornalistas tiveram que reaprender a trabalhar com a liberdade, pois a ditadura havia deixado muitas seqüelas, entre eles, a autocensura, por exemplo. A preocupação dos jornalistas deixa de ser com o formato e passa a se fixar no conteúdo: "a forma está definida, a filosofia é pacífica, isto é, um jornal de "hard news", "manchetado", absolutamente substantivo, que não se arraste, que seja seletivo - este é Jornal Nacional", declarou, na época, Armando Nogueira (MELLO E SOUZA, 1984: 268).

Mas os anos 80 acabaram trazendo muitos problemas polêmicos de credibilidade para o JN: a campanha das diretas em 1984 e o debate Collor X Lula, em 1989. No primeiro caso, o JN não teria mostrado o megacomício realizado em 25 de janeiro, na Praça da Sé, em São Paulo. O que foi ressaltado na matéria foi o aniversário da cidade e não o movimento pelas diretas, que estava em curso em todo o país. No segundo caso, o JN teria editado o último debate entre os dois candidatos de forma que Collor parecesse ter massacrado Lula, dando um minuto e meio a mais de tempo 
para o primeiro candidato. A edição também utilizou os melhores momentos de Collor, em contrapartida aos piores de Lula. O resultado desse segundo caso foi a saída do diretor de jornalismo da Globo, Armando Nogueira, e a subida para o posto do jornalista Alberíco Souza Cruz, que foi apontado como mentor intelectual da edição do debate.

A credibilidade do JN só foi restabelecida totalmente em 2004, quando o telejornal completou 35 anos e fez uma grande reflexão sobre a sua história, colocando todos os personagens para darem as sua versão dos fatos no livro Memória Globo - Jornal Nacional - A notícia faz a história. Uma grande reportagem sobre os bastidores do $J N$ também foi publicada pela revista Veja, em $1^{10}$ de setembro do mesmo ano (edição 1869 ano 37 -nํ․ 35 de $1^{\circ}$ de setembro de 2004 páginas 100 até 108). Nesta reportagem de Veja o vicepresidente das organizações Globo, João Roberto Marinho faz uma reflexão:

Aos poucos, depois de refletir sobre o assunto e com o distanciamento que o tempo dá, eu tenho uma avaliação diferente dos fatos. Depois desses anos todos, eu acredito que as duas edições (a exibida no Jornal Hoje e a mostrada no Jornal Nacional estavam erradas: uma exagerou para um lado e a outra ficou aquém para o outro. De qualquer forma, eu debito os dois erros à inexperiência de todos na época. É preciso sempre ter em mente que aquela era a primeira eleição para presidente na era da televisão de massa. Não passa pela minha cabeça que os equívocos tenham sido cometidos por má-fé. (revista Veja edição 1869 ano 37 -nํ․ 35 p. 105)

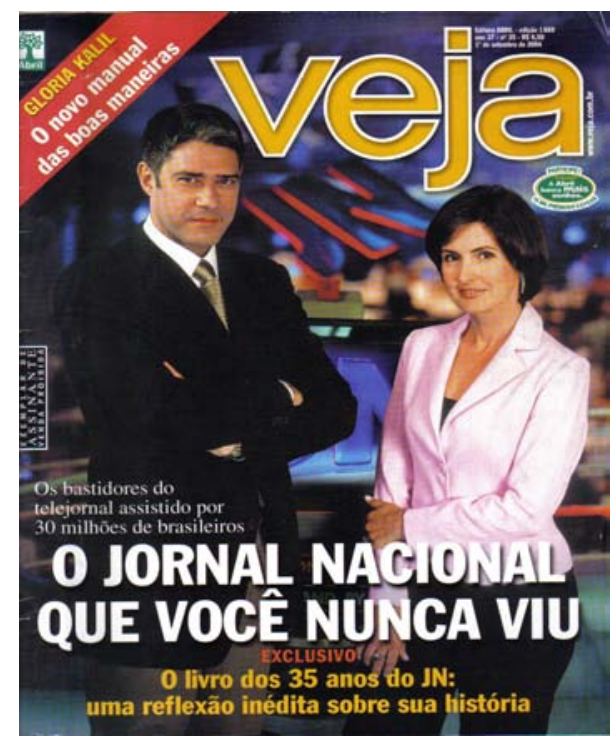


Em 21 de abril de 1971, também entrou no ar o Jornal Hoje. Os primeiros apresentadores foram Léo Batista e Luís Jatobá. Na primeira versão, restrita apenas ao telespectador do Rio de Janeiro, era uma revista diária, com matérias sobre arte, espetáculos e entrevistas. A partir de 3 de junho de 1974, passou a ser exibido para todo o território nacional. Contava com uma sessão de moda, de Cristina Franco, previsões astrológicas, receitas, crônicas de Rubem Braga, as tendências musicais, com Nelson Motta, as dicas de cinema, com Rubens Ewald Filho, e informações do Brasil e do mundo. Teve também como apresentadoras Sônia Maria, Ligia Maria e Márcia Mendes. Inovou, ao mostrar, pela primeira vez na televisão brasileira, repórteres sem gravata e com cabelos compridos, que eram moda na época. Numa segunda fase o telejornal era comandado por três apresentadores, um no Rio, outro em São Paulo e o terceiro, em Brasília.

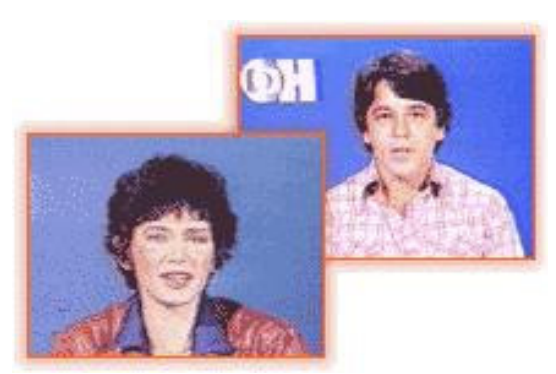

A apresentadora Márcia Mendes e o comentarista Nelson Motta (http://jornalhoje.globo.com/JHoje)

As reportagens vinham de todas as capitais do país. As entrevistas realizadas por Leda Nagle consagraram uma marca do telejornal, pois revelavam inquietações, êxitos, fracassos e os planos das mais diversas personalidades do Brasil. Personalidades como Carlos Drummond, Pelé, Caetano Veloso e Tom Jobim passaram por lá. 


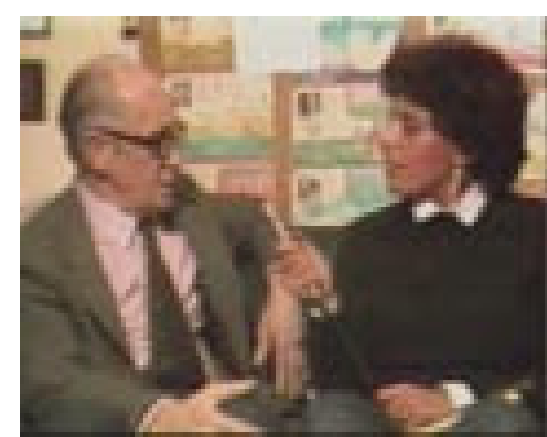

Leda Nagle entrevista Carlos Drummond (http://jornalhoje.globo.com/JHoje)

Nos anos 80, mais precisamente em 1981, o cenário muda para um estilo mais moderno, avançado e espaçoso.

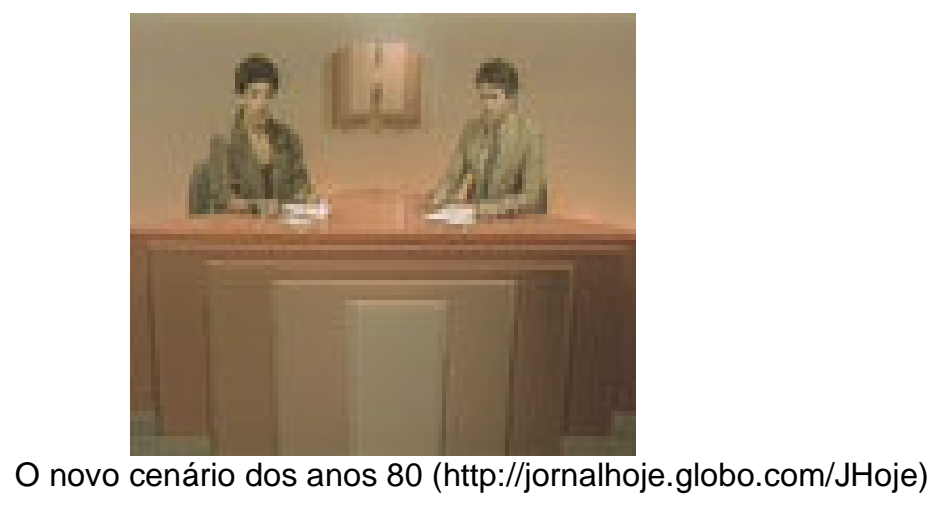

Nos anos 90, novas mudanças no cenário e no formato do telejornal, com $90 \%$ de notícias de atualidade, invertendo a tendência inicial e privilegiando as entradas de repórteres ao vivo. O editor-chefe da época era o jornalista Edson Ribeiro e a apresentação era de Valéria Monteiro e Márcia Peltier. Outras modificações desta fase são o quadro Você, de Cristina Franco, sobre beleza, o bloco de cultura, com Maurício Kubrusly, e as entrevistas que a correspondente de Londres, Beth Lima, fazia com personalidades de diversos países.

No final dos anos 90, a jornalista Sandra Annemberg começou a apresentar o Jornal Hoje, que ainda era transmitido do Rio de Janeiro, mas, em 1999, o telejornal passou a ser produzido nos novos estúdios de São Paulo. A apresentação ficou a cargo do jornalista Carlos Nascimento, pois Sandra Annemberg foi trabalhar como correspondente em Londres. Em 2001, o 
telejornal passou a ser exibido direto da redação e o apresentador Carlos Nascimento, junto com Carla Vilhena, passaram à função de âncoras.

Em 2003, o Jornal Hoje retorna às suas origens de ser telejornal-revista e volta a exibir entrevistas especiais, gravadas e ao vivo. Também ganham destaque os grandes temas de comportamento humano, social e ético, com a tradicional linguagem coloquial. A apresentação é de Carlos Nascimento e Sandra Annembrg. A última mudança é a entrada de Evaristo Costa na apresentação, devido à saída de Carlos Nascimento da emissora.

Em 05 de agosto de 1973, em plena ditadura militar, a tevê Globo lança mais programa em rede nacional - O Fantástico, o show da vida. Tratava-se uma revista semanal, exibida aos domingos, com entretenimento e informação, de uma forma dinâmica e acessível. Era uma proposta inédita para a época e tinha a direção-geral de Augusto César Vanucci. A nova proposta misturava musicais, notícias internacionais, humor, teleteatro, números de variedades e noticiário diário. Cid Moreira estava na apresentação desde o primeiro programa. O jornalismo começa a ganhar força somente em 1977, com a direção-geral de José-Itamar Freitas. Tudo podia ser fantástico, desde que estivesse baseado na informação. Nos anos 80, o programa abandonou o seu estilo de revista e passou a ser um telejornal mais voltado para atualidades, com a apresentação dos jornalistas Willian Bonner, Sérgio Chapelin e Valéria Monteiro. Em 1998, ao completar 25 anos, o Fantástico é o primeiro a ter email e a transmitir pela internet em tempo real. Também inaugurou a transmissão digital no Brasil, direto da França, durante a Copa do Mundo. Em 2005, o programa ganha a sua primeira versão impressa - Almanaque do Fantástico. Segundo Ballut Vizeu, a criação do Fantástico foi baseada no programa Big Lar Show, da tevê Rio, que já nos anos 60 inovou com uma mistura de vários estilos, unindo informação e entretenimento.

Nos anos 80, com o processo de redemocratização do país em curso e o movimento feminista crescendo no mundo inteiro, a emissora cria um programa em sintonia com o momento do país - TV Mulher. De acordo com Paternostro (1999: 36), um programa jornalístico dedicado à mulher, exibido todas as manhãs, de segunda à sexta-feira, das 8:00h às 11:00h. Produzido pela tevê 
Globo São Paulo, ficou seis anos no ar. Era apresentado pela jornalista Marília Gabriela, com participação de Marta Suplicy, Ney Gonçalves Dias, Clodovil, entre outros. Os assuntos eram temas novos que, até então, não haviam sido mostrados na televisão, como comportamento sexual, direito e saúde da mulher, o posicionamento feminino na sociedade e a mulher como profissional.

Em 1983, é lançado o Bom Dia Brasil - um telejornal matutino, visto que os telejornais locais já haviam conquistado espaço. A diferença é que o Bom Dia Brasil era em rede nacional e gerado de Brasília, com prioridade para os assuntos políticos e econômicos. Atualmente, não é mais gerado em Brasília e, sim, no Rio de Janeiro e tem uma gama mais ampla de assuntos apresentados e inclusive com a participação de comentaristas. A primeira inclinação deste telejornal pela política e pela economia deveu-se ao momento de abertura política e pelo processo de redemocratização que o país passava. As principais praças do país entram ao vivo com as notícias de maior importância. Outras experiências regionais, como o SPTV, em São Paulo, já foram importantes nos anos 90 , porque apresentaram, na tevê, o jornalismo comunitário, ou seja, o destaque para as notícias da região e da comunidade.

Em 29 de janeiro de 1999, a tevê Globo de São Paulo inaugurou uma sede nova, com $16.500 \mathrm{~m}^{2}$, para acomodar toda a equipe de telejornalismo, com tecnologia digital e equipamentos de última geração.

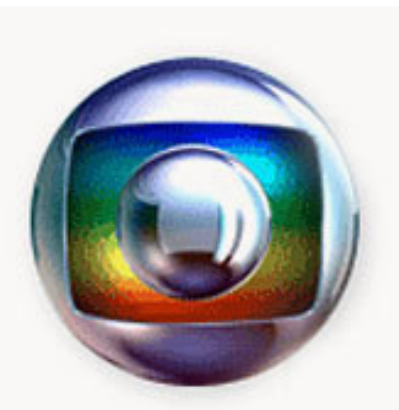

O logotipo criado pelo designer Hans Duner

E por falar em Jornalismo Comunitário, a primeira emissora do interior da América Latina foi implantada na cidade de Bauru, no interior de São Paulo, pelo visionário João Simonetti e se chamou tevê Bauru. 
Na década de 50, o empresário João Simonetti já cogitava implantar na cidade de Bauru uma emissora de tevê. A cidade tinha, nesta época, em torno de 53 mil habitantes. O prefeito Nicola Avalone Júnior deixou a prefeitura em março de 1959, quando a cidade vivia a expectativa da chegada de uma tevê inteiramente bauruense, para assumir um cargo de deputado estadual. O vice, Luis Zuiani, torna-se, então, o prefeito do primeiro município do interior a conquistar a televisão.

Bauru concedeu apenas a mil felizardos a oportunidade de fazer parte da primeira turma de telespectadores. Foram eles que adquiriram os primeiros aparelhos da Rebratel (Rede Brasileira de Televisão), vendidos, de porta em porta, para concretizar o sonho de João Simonetti.

De acordo com o jornalista Marcio ABC, a Rebratel, dona de tecnologia para implantar uma emissora, e da qual partiu a exigência para que fosse vendida a cota de mil televisores, instalou a torre de retransmissão na cidade e, em poucas semanas, fez-se o milagre: a televisão aportou em Bauru.

Só não se tem certeza da data exata em que a televisão bauruense entrou no ar, entre os últimos anos da década de 50 e o início dos anos 60 . Oficialmente, a TV Bauru - Canal 2, primeira emissora interiorana da América Latina, entrou em funcionamento no dia $1^{\circ}$ de agosto de 1960 , mas antes disso, a emissora já operava, sem que a Presidência da República tivesse concedido, ainda, a licença, em caráter experimental. Conforme os jornais da época, algumas transmissões experimentais ocorreram lá pelos meses de junho e julho de 1959.

De acordo com os jornais da época e alguns documentos do arquivo da emissora, o sonho de João Simonetti de implantar uma emissora de tevê na cidade de Bauru levou cerca de 10 anos para ser concretizado, pois desde fevereiro de 1951, o interesse de João Simonetti por uma estação de TV já era notícia na cidade: "Uma Estação de Televisão para Bauru está na cogitação do sr. João Simonetti”. (ABC; 2001: 15).

No dia 04 de abril de 1952, Simonetti assinou o primeiro ofício, dirigido ao Ministério da Viação e Obras Públicas, órgão responsável na época pelas concessões para rádio e TV, no país. Em novembro do mesmo ano, outro ofício, com conteúdo parecido com o primeiro, é enviado ao Ministério da Viação (ABC; 2001: 27). Em cinco de abril de 1952, a ousadia de João 
Simonetti e o envolvimento político o levam a enviar uma carta ao presidente da República, Getúlio Vargas, para pedir a televisão bauruense (ABC; 2001: 29). Em outubro de 1959, um ano antes da inauguração oficial da TV Bauru, a imprensa anuncia a chegada de novas câmeras para a emissora: "A TELEVISÃO EM BAURU É MESMO UMA REALIDADE: CHEGARAM AS NOVAS CÂMERAS DA TV-BAURU CANAL 2" (ABC; 2001: 44).

O primeiro telejornal da TV Bauru foi "O Nosso Jornal", noticiário que era inteiramente local.

Depois veio "O Globo Agora à Noite", que ia ao ar entre $22 \mathrm{~h} 15$ e 22h40, com as principais informações nacionais e internacionais, que eram juntadas com o noticiário de Bauru. Era apresentado por Paulo Sérgio Simonetti e Fred Calmon.

Nos anos seguintes, programas de variedades, teleteatro e até uma telenovela foram produzidos na TV Bauru. Em 1969, a Globo começa a integrar o país, através de sua programação nacional. O Jornal Nacional, que estreou no dia $1^{\circ}$ de setembro daquele ano, era para todos, ao mesmo tempo. A partir daí, foram extintos os programas caseiros e houve também a redução do tempo para o jornalismo local. A evolução tecnológica roubou a cena da nova etapa da TV Bauru.

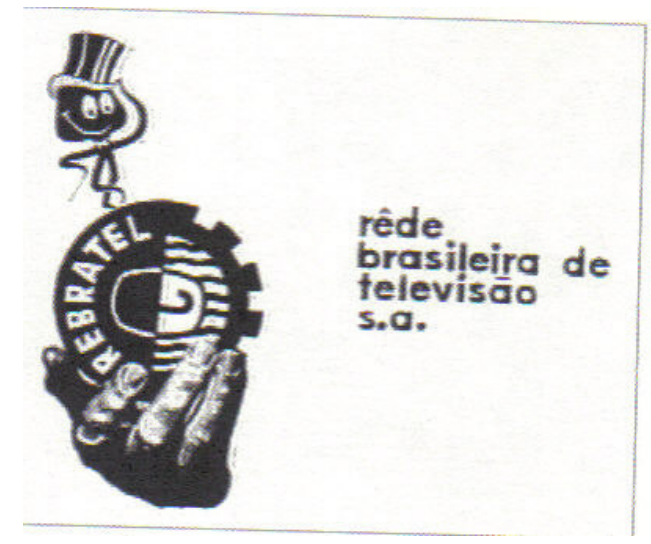

O logotipo da Rebratel, que era parceira de Simonetti (ABC; 2001: 18).

O "Jornal Hoje", apresentado por Alonso Compoi, foi ao ar até o ano de 1973, sempre ao meio-dia, e tinha aproximadamente meia hora de duração. O jornal era apresentado ao vivo, sem o teleprompter (onde o locutor lê a notícia). 
Apenas uma equipe de reportagem sobreviveu para contar a história da década de 70. Jair Aceituno (repórter), Moacir Mendonça e Walcir Coelho (cinegrafistas), e Carlos Torrente (iluminador) passaram cinco anos, de 1974 a 1979, correndo o interior do Estado, atrás de notícias. Elas abasteciam o "Globo Interior", espaço que a Globo reservava para as notícias do interior. Não havia edição em Bauru. As fitas eram despachadas, brutas, para a capital. Este período teve essa inexpressividade devido ao controle exercido pela ditadura militar.

O jornalismo só voltou a ser produzido na TV Bauru, no dia 28 de fevereiro de 1980, coincidentemente, 25 dias após o fim da já debilitada censura ao telejornalismo brasileiro. Os quinze minutos de duração do jornal eram preenchidos pelo trabalho de uma só equipe de reportagem, com uma única câmera, tanto para as externas como para apresentação do telejornal, que, na época, era gravado. O jornalista Luiz Antônio Malavolta abriu o bloco local do "Jornal das Sete", com o "boa noite" seguido de uma promessa: "A partir de hoje, a região oeste de São Paulo ganha uma nova forma de comunicação". (ABC; 2001: 93)

Durante o período em que era gravado, o "Jornal das Sete", Luiz Antônio Malavolta revezava-se na bancada com Kitty Balieiro, Beth Ferreira e Luiz Carlos Azenha. O primeiro apresentador fixo do "Jornal das Sete", depois de algum tempo, passou a ser Gilberto de Barros. Nesta fase, também começa a utilização do primeiro equipamento de videocassete portátil e de qualidade (UMATIC). Com o sistema, foi possível fazer a edição de toda a produção jornalística de Bauru e dos comerciais também. Apenas uma ilha era compartilhada pelo jornalismo e pela produção comercial.

Em 1983, os repórteres da TV Bauru eram Arnaldo Duran, Luiz Carlos Azenha, Rosa Maria Abrão, Carlos Magagnini e Kleber Santos. No ano seguinte, a TV Bauru - Canal 2 mudou de nome, passou a chamar-se Rede Globo Oeste Paulista. Foram inauguradas sucursais em Presidente Prudente, Marília, São José do Rio Preto e mais tarde em Araçatuba.

Com fortes investimentos em profissionais, equipamentos e instalações, a nova estrutura da emissora passava a ser composta por 11 equipes de jornalismo - quatro em Bauru, uma em Araçatuba e duas em cada uma das outras três sucursais (ABC, 2001: 104). 
Para dar suporte a este projeto, foi escalado Mauro Gonçalves, um homem da área comercial da Rede, que ficaria como diretor regional da emissora até junho de 1998.

Neusa Rocha foi a primeira editora regional, mas quem fez a transição como editor regional foi Raul Martins Bastos. Depois, quem assumiu e editoria regional foi o jornalista Celso Pelosi, que já era editor de texto da casa. Nesta época, existiam três edições do SPTV: SPTV-1, SPTV-2 e SPTV-3. Pelosi ficou até o final de 1987. Depois de passar pela TV Morena e pela TV Vale do Paraíba, em 1990, Pelosi retorna para Bauru, novamente como editor regional. Cinco anos depois foram extintas as editorias regionais. Só em 1995, as mesmas foram recriadas.

\footnotetext{
Pelosi, então, voltou para Bauru e não encontrou mais Presidente Prudente na área de abrangência da emissora. Há cerca de um ano funcionava a TV Fronteira, que mais tarde levaria para comandar seu jornalismo o repórter, e posteriormente chefe de redação em Bauru, Marcos Gomide (ABC, 2001).
}

Em outubro de 1998, a Rede Globo Oeste Paulista também é vendida e passa a se chamar TV Modelo. O primeiro editor regional é Marcos Pizano, que, no ano de 2000, foi substituído por Osmar Chor.

Todas estas mudanças fazem parte da crise em que a Rede Globo estava mergulhada, naquele momento. A venda das emissoras repetidoras era uma estratégia para manter os negócios, que davam prejuízo, devido à implantação da GloboCabo, que comprava programação em dólares e vendia assinaturas em reais. Para a cúpula das organizações Globo, essas mudanças faziam parte do "Projeto regional do Futuro", planejado para dar mais autonomia às unidades regionais.

A nova diretriz era deixar de ser apenas um veículo que transmite notícias e, então, embarcar na era da integração comunitária. Os telejornais, que tinham pouco mais de quinze minutos, ampliaram o tempo para mais de uma hora. "Tânia Guerra, que em 2000 era a apresentadora com mais tempo de casa, e seus colegas de bancada dos recentes anos da TV Modelo, começavam a deixar para trás a imagem dos locutores noticiaristas" (ABC, 2001: 124).

Mas uma nova estava por vir. Em maio de 2003, o grupo que mantinha a TV Modelo vendeu a emissora mais uma vez. A partir daí, ela passou a 
chamar-se TVTEM e a integrar uma rede, com filiais em São José do Rio Preto, Sorocaba e Itapetininga.

Atualmente, os telejornais que estão no ar são: "TEM Notícias", em duas edições, ao meio dia e às sete da noite, e o "Bom Dia Cidade", que vai ao ar às 6 h30 da manhã. A equipe de jornalistas é totalmente nova e o gerente regional é Hélio Kimelblat.

\section{3 - A configuração dos telejornais nos anos 70: TV Gazeta e Rede Bandeirantes}

A tevê Gazeta de São Paulo - canal 11 foi inaugurada em 25 de janeiro de 1970, pela Fundação Cásper Líbero, como parte das comemorações do aniversário da cidade. Localizada no ponto mais alto de São Paulo, na Avenida Paulista, a emissora sempre tentou se firmar como a mais paulista das emissoras, ou seja, uma tevê com a cara da cidade.

Com o sinal em UHF e VHF, a emissora cobre a capital paulista e um raio de 100 quilômetros, chegando aos municípios da grande São Paulo, como São Carlos, Sorocaba, Rio Claro, Limeira, Americana, Bragança Paulista, Araras e o ABC. Com a transmissão por satélite, a programação também pode ser acompanhada pela rede de parabólicas, tanto no Brasil como no exterior.

Desde sua inauguração, o forte de sua programação sempre foi o jornalismo, através de debates, esportes, entrevistas e programas femininos.

O jornalismo é composto atualmente pelo Jornal da Gazeta, que vai ao ar, de segunda a sábado, com a jornalista Maria Lydia com o participação de Anna Paola. Conta, também, com o comentarista Celso Cardoso e possui, também, uma editoria regional em Brasília, sob a responsabilidade do jornalista Florestan Fernandes Júnior.

A tevê Gazeta tem tradição na faixa esportiva, com os programas Gazeta Esportiva (noticiário diário sobre esporte) e o Mesa Redonda (reunindo jogadores, técnicos, dirigentes e personalidades que expõem suas opiniões sobre o futebol) que estão no ar desde a inauguração da emissora. 
Outra marca da programação informativa da emissora são os programas femininos, com assuntos variados, para auxiliar o cotidiano da mulher moderna, que mesclam informação, entretenimento, receitas e entrevistas, como o Pra Você, apresentado por lone Borges, o TV Culinária, apresentado pela culinarista Palmirinha, e o Mulheres, que está no ar há 28 anos, e atualmente é apresentado por Cátia Fonseca.

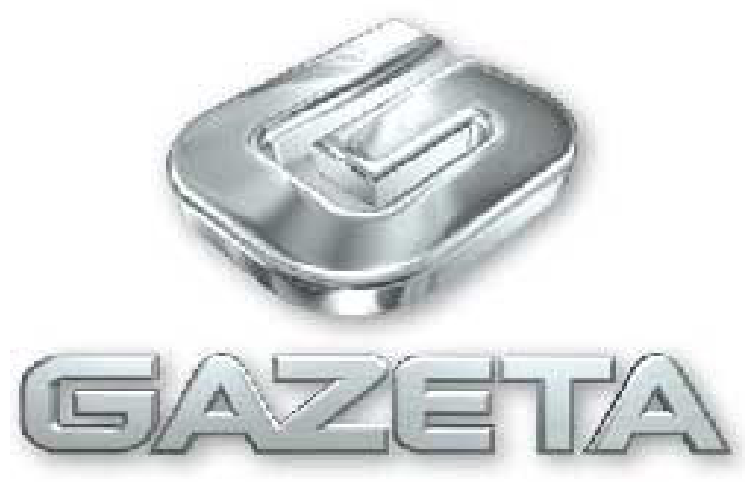

Nos anos 80, a tevê Gazeta participou de uma fase onde a linguagem telejornalística ganhou cara nova, com a videoreportagem ou, como foram chamados, os repórteres-abelhas. Isto ocorreu, mais precisamente, em 1987, conforme o artigo A linguagem experimental da videoreportagem, de Patrícia Thomaz. A tevê Gazeta, com o programa TV $M I X$, que era uma grande programação de variedades da emissora, inovou com uma equipe de videorepórteres. O diretor do programa, Fernando Meireles sem muitos recursos para produzir a cobertura jornalística local, criou o videorepórter. No início, as videoreportagens eram feitas de forma amadora, por estudantes ou profissionais de outras áreas, mas, depois, passaram a serem produzidas por jornalistas preocupados não só com a forma, mas, também com o conteúdo. $O$ programa TV MIX saiu do ar em 1990.

A TV Bandeirantes - canal 13 de São Paulo foi inaugurada em 13 de maio de1967. A concessão, conseguida por João Saad ainda no governo de Getúlio Vargas, só iniciou a construção no ano de 1961. O Edifício Radiantes, um prédio construído para abrigar a tevê Bandeirantes, foi apelidado pelos funcionários de "palácio encantado". 
Desde sua criação até os dias de hoje, pouco se conseguiu verificar a respeito do histórico de seus telejornais. O primeiro telejornal denominado Titulares da Notícia fazia um esquema próximo ao telejornais da época: tinha alguns redatores e poucas reportagens com filme mudo, em preto e branco. $O$ que se valorizava naquele momento, de acordo com Bacic, era o texto. Grande parte dos telejornalistas incorporados à equipe eram oriundos da Rádio Bandeirantes. De acordo com Xavier, o Titulares da Notícia foi considerado por muitos não como um telejornal, mas como boletins informativos.

Em 1973, sob a direção de Cláudio Petraglia, a Bandeirantes foi pioneira na programação colorida.

Como a emissora já estava conseguindo algum lucro, em 1975, o grupo compra a tevê Vila Rica, de Belo Horizonte, e dá início à formação de uma rede. Depois, em 1977, para dar continuidade à formação da rede Bandeirantes, entra no ar a tevê Guanabara, que só vai passar a se chamar Bandeirantes em 1978. Outras 12 pequenas estações compõem finalmente uma rede.

O apelido Band, utilizado pela Rádio Bandeirantes-FM, é adotado para o vídeo, também, e acaba emplacando na tevê.

Alguns programas jornalísticos de sucesso da Bandeirantes foram:

Canal Livre - lançado em 1986, sob a apresentação da jornalista Silvia Poppovic, o programa debatia temas considerados polêmicos e nunca vistos na tevê, como: prostituição, homossexualismo, traição, entre outros. Aproveitando o momento da abertura política, que estava em curso no país, o Canal Livre foi um referencial para debates acalorados, com a participação de pessoas com opiniões contrárias;

Show do Esporte (1983) - maratona comandada por Luciano do Valle;

Cara a Cara (1988) - programa de entrevista comandado por Marília Gabriela. Esteticamente diferente, na sua primeira versão, porque usava o big close, tanto da apresentadora quanto do entrevistado, para mostrar as ações e reações dos mesmos.

O telejornal de maior sucesso da Bandeirantes foi o Jornal da Band, que inaugurava uma nova liderança, com o jornalista Paulo Henrique Amorin. Ele exercia os papéis de repórter, apresentador e editor-chefe. A experiência 
começou em 17 de fevereiro de 1997, mas ficou no ar somente até 12 de janeiro de 1999.

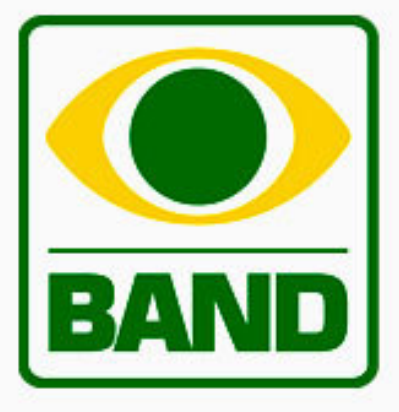

O logotipo atual da Bandeirantes

\section{4 - A configuração dos telejornais nos anos 80 : SBT e TV Manchete}

O empresário Silvio Santos, desde os anos 70 , quando terminou seu contrato com Rede Globo, onde ele comprava horário aos domingos para exibir os seus programas e anunciar o carnê do Baú da Felicidade, tentava conseguir uma concessão de televisão. Em 1973, ele perdeu uma concorrência dos canais 9 de São Paulo e do Rio de Janeiro para o Jornal do Brasil. Depois, perdeu outra concorrência, no ano seguinte, para a tevê Bandeirantes, que ficou com o canal 7 do Rio de Janeiro. Somente em 23 de outubro de 1975, Silvio Santos conseguiu sua primeira concessão, no Rio de Janeiro, que foi disputada com Editora Bloch, a Fundação Cásper Líbero e a Editora e Impressora.de Jornais e Revistas. O passo seguinte do empresário foi comprar a massa falida da tevê Continental, por $\operatorname{Cr} \$ 603$ mil, mas a concessão só foi oficializada em 22 de dezembro de 1975. A emissora foi montada na rua General Padilha, número 134, em São Cristóvão, mas o primeiro programa só foi ao ar depois de 144 dias, em 14 de maio de 1976, às 20h55. A TVS canal 11 exibiu uma edição do programa Silvio Santos, simultaneamente com a tevê Record de São Paulo, emissora da qual o empresário possuía ações. A 
programação transmitia filmes, flashes jornalísticos de três minutos e programas de variedades.

Em 1981, a TVS passou a integrar o SBT - Sistema Brasileiro de Televisão. No mesmo período, Silvio Santos recebe a autorização para operar o canal 5 de Porto Alegre, o canal 2 de Belém, o canal 9 do Rio de Janeiro e o canal 4 de São Paulo. Outras emissoras afiliadas independentes também compuseram a novo sistema. De acordo com Xavier, a substituição do termo "rede" por "sistema" deve-se por Silvio Santos não possuir uma emissora líder e fazer do canal paulista uma central independente de produção, dando liberdade para as emissoras afiliadas retransmitir ou não seus programas, de acordo com seus interesses.

A TVS paulista ocupou o canal 4, que estava fora do ar há mais de um ano, depois do fim da Tupi. A nova emissora absorveu uma parte dos funcionários da Tupi e utilizava os $11.000 \mathrm{~m}^{2}$ da extinta tevê Excelsior, na Vila Guilherme, que eram alugados por Silvio Santos, da Caixa Econômica Federal, desde 1972.

A estréia do novo "sistema" aconteceu em 19 de agosto de 1981, batendo um recorde inédito no Brasil: entrar no ar no mesmo dia da oficialização da concessão. Tendo sido transmitido ao público a assinatura do contrato entre o Ministério das Comunicações e o SBT, em Brasília. A programação da emissora foi focada para as classes $C, D$ e E.

O primeiro programa jornalístico foi O Elevador - um programa de entrevistas com o jornalista Ferreira Neto

O primeiro telejornal de sucesso do SBT foi ao ar em 4 de maio de 1988. O TJ Brasil foi o primeiro noticiário da televisão brasileira a trazer a figura do âncora - jornalista que dirige, apresenta e comenta as notícias do jornal. $O$ jornalista Boris Casoy foi treinado nos Estados Unidos, com um âncora americano, e em pouco tempo conseguiu reproduzir o jornalismo opinativo na televisão brasileira. A experiência durou até o ano de 1997, quando Boris e sua 
equipe foram para a TV Record, onde permaneceram até ao ano de 2006, quando foi substituído por um casal de apresentadores.

Com o tempo, o SBT ocupou o segundo lugar, de acordo com a pesquisa feita pelo IBOPE - Instituto Brasileiro de Opinião Pública e Estatística, mas isso não agradava o empresário Silvio Santos.

Em 1994, o SBT iniciou a construção de sua sede própria, em uma área no quilômetro 18 da rodovia Anhanguera. A inauguração da nova sede aconteceu em 19 de agosto de 1996, com a comemoração de 15 anos da emissora. O Complexo Anhanguera possui uma área de $210.000 \mathrm{~m}^{2} \mathrm{e}$ modernas instalações e estúdios de tevê.

Outra experiência do SBT foi o Aqui Agora, telejornal que entrou no ar em maio de 1991. O nome é uma referência ao telejornal Aqui e Agora, exibido anteriormente pela tevê Tupi, onde a versão atual retirou o "e" do título do programa. Com um estilo sensacionalista, com reportagens policiais, cheio de ação, aventura, flagrantes, denúncias, violência e tensão. Tinha duas horas de duração e contava com um grupo de apresentadores e repórteres, como Luiz Lopes Correa, Jacinto Figueira Júnior, Gil Gomes, João Leite Neto, Celso Russomano, Gerson de Souza, Madalena Bonfigliole e César Tralli, entre outros. A violência foi prestigiada durante toda a década de 90 e fez com que outras emissoras copiassem a fórmula, para competir pela audiência. Com o tempo, a fórmula se esgotou e o mesmo saiu do ar no final de 1997. Neste mesmo ano, a emissora encerrou as atividades do departamento de jornalismo, que havia feito tanto sucesso e inovado a fórmula do telejornalismo, com o sensacionalismo do Aqui Agora e a opinião de Boris Casoy, mantendo apenas um noticiário requentado de final de noite, com o jornalista Hermano Hening. Em entrevista exclusiva à revista Veja - edição 1649 -ano 33, № . 20, de 17 de maio de 2000 (páginas 148 até 157), Silvio Santos relata o porquê do desmonte do departamento de jornalismo da emissora:

Era muito dinheiro jogado fora. No caso do jornalismo, houve uma briga entre o Marcos Wilson, diretor do departamento, e o Boris Casoy. Por isso, para cada evento, mandavam duas equipes, uma do Marcos e 
outra do Boris. Essa brincadeira saía caríssimo - 30 milhões de reais por ano. O Boris ainda trazia uma boa grana, mas o jornalismo como um todo dava prejuízo (Veja - edição 1649 -ano 33 no. 20 de 17 de maio de 2000 p.151).

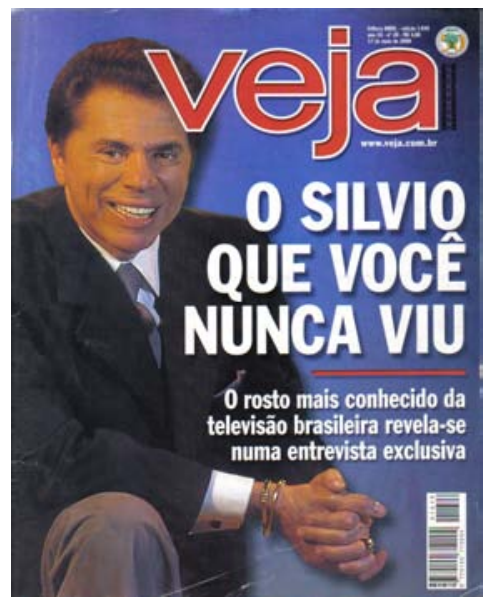

Silvio Santos, em entrevista exclusiva a revista Veja em 2000.

Em 2003, o empresário Silvio Santos, em parceria com o sociólogo Carlos Novaes, fundaram o Datanexus - um instituto de pesquisas, que utilizava metodologia diferente do IBOPE e consequentemente apresentava resultados diferentes. Silvio Santos investiu $\mathrm{R} \$ 4$ milhões e foi o único cliente do novo instituto. Depois de um ano e meio de monitoramento de 250 domicílios, na grande São Paulo, o Datanexus ficou sem seu único cliente e foi abrigado a encerrar as atividades, pois tinha um custo mensal de $\mathrm{R} \$ 200$ mil.

Em 2008, o SBT retomou a idéia do Aqui Agora, mas a experiência durou apenas 2 meses. Depois do fracasso de audiência, cerca de 50 jornalistas foram demitidos.

$\mathrm{Na}$ fase atual do SBT, com a retomada do telejornalismo, desde 2005, entre telejornais e programas jornalísticos estão no ar. Na categoria programas jornalísticos, compõem a programação:

-SBT Repórter: programa jornalístico com grandes reportagens, baseadas em investigação detalhada para mostrar ao telespectador fatos históricos, descobertas científicas e assuntos de curiosidade pública. Com uma linguagem direta, para mostrar assuntos do Brasil e do mundo, é apresentado pelo jornalista César Filho; 
-SBT Realidade: programa especial de reportagens, apresentado e idealizado pela jornalista Ana Paula Padrão;

$\mathrm{Na}$ categoria telejornalismo, três telejornais são exibidos diariamente:

-Jornal do SBT Manhã: no ar, desde setembro de 2005, apresenta as primeiras informações do dia, com os jornalistas Hermano Henning e Analice Nicolau;

- Jornal do SBT Noite: telejornal do horário nobre da televisão, com as notícias do dia em todas as editorias, com apresentação de Carlos Nascimento e Cynthia Benini;

-SBT Brasil: um resumo das principais notícias do dia, com apresentação de Carlos Nascimento e a participação dos telespectadores sobre um assunto polêmico do dia, através do telefone.

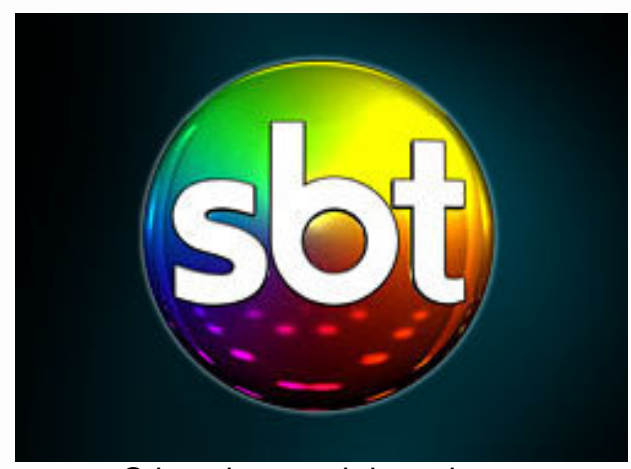

O logotipo atual da emissora.

A Rede Manchete de Televisão, de propriedade do grupo Bloch, foi inaugurada em 05 de junho de 1983 (http://www.redemanchete.net/ acesso em 25 de maio de 2008). O diferencial da emissora eram os documentários e os programas criados por produtoras independentes, com o objetivo de agradar as classes altas. O empresário Adolpho Bloch investiu U\$ 50 milhões em qualidade e demorou quase dois, após o recebimento da concessão, para inaugurar a tevê Manchete. 
Sob a direção do jornalista Zevi Ghivelder, o departamento de jornalismo inovou, com um telejornal de três horas de duração - o Jornal da Manchete. $O$ telejornal entrou no ar em 06 de junho de 1983 e foi considerado, por muitos especialistas, como o mais completo da televisão. O telejornal era dividido em várias editorias, que com o tempo acabaram dando origem a outros programas distintos, como foi o caso do Manchete Panorama, que cobria artes e espetáculos, do Manchete Esportiva e do Manchete Internacional. O Jornal da Manchete chegou a contar com uma segunda edição, que ia ao ar às 23h30, direto de São Paulo, e, depois, surgiu também o Jornal da Manchete Edição da Tarde. Os primeiros apresentadores foram os jornalistas Ronaldo Rosas e Carlos Bianchinni. Em agosto de 1989, o Jornal da Manchete inova e contrata Leila Cordeiro e Eliakim Araújo para apresentar o telejornal, criando o conhecido "casal 20" do telejornalismo.

Nos anos 90, Jornal da Manchete Edição da Tarde passa a ser ancorado de três capitais brasileiras, Rio de Janeiro, São Paulo e Brasília, e ganha a denominação de Edição da Tarde. A outra mudança é que o Segunda Edição passa a se chamar Noite Dia, com apresentação de Renato Machado, no Rio de Janeiro, Paulo Markun, em São Paulo e Carlos Chagas, em Brasília.

Em 1992, com as saídas de Leila Pinheiro e Eliakim Araújo da emissora, a jornalista Márcia Peltier assume a apresentação, com o apoio de Florestan Fernandes Júnior, de São Paulo, e Carlos Chagas, de Brasília. Nesta época, a Manchete já utilizava a redação ao fundo de seus telejornais, como cenário, numa alusão à emissora norte-americana CNN.

Em 1996, em plena crise, o Segunda Edição foi substituído pelo Manchete Verdade, que foi apresentado inicialmente por Marcos Hummel e, depois, por Ronaldo Rosas.

Em 1998, depois de várias reformulações no departamento de jornalismo, os telejornais voltam a ser divididos em três edições: Jornal da Manchete Edição da Tarde, Jornal da Manchete e Jornal da Manchete Edição da Noite, apresentadas por Elisa Mendes, Márcia Peltier e Claudia Barthel, respectivamente. 


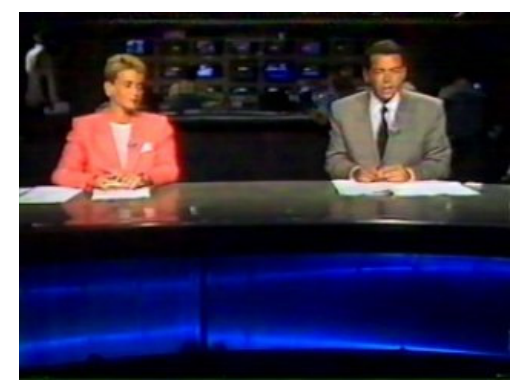

Leila Pinheiro e Eliakim Araújo - o "casal 20" do telejornalismo (http://www.redemanchete.net/)

Outro destaque jornalístico da Rede Manchete foi o Documento Especial, que estreou em 1989. O programa era apresentado por Roberto Maya e dirigido por Nelson Hoineff. Tratava-se de um programa de grandes reportagens, com duração de cerca de 30 minutos, no estilo do Globo Repórter, mas com uma grande diferencial, que eram as temáticas incomuns na televisão brasileira naquele momento, como prostituição, homossexualismo feminino, espiritismo, entre outros. As cenas fortes eram exibidas na íntegra, em planos longos, que também não eram comuns. Alguns dos programas de maior audiência foram: Os pobres vão à praia, Muito feminina, Luta Livre, O suicídio dos índios Kaiowá, Amor, Vida de gordo e Igreja Universal. Na Manchete, o programa ficou no ar até 1991, sendo depois apresentado no SBT e na Bandeirantes.

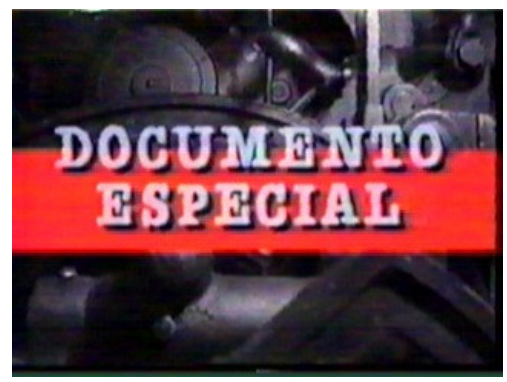

A abertura do Documento especial (http://pt.wikipedia.org/wiki/Documento_Especial).

Outra marca do jornalismo da tevê Manchete foi o Programa de Domingo - uma revista semanal que estreou em 1983 e ficou 15 anos no ar, até 1998. No conteúdo do programa, além dos fatos da semana, dicas de moda e comentários dos mais variados tipos, como cinema, política, economia e espetáculos. $\mathrm{Na}$ apresentação do programa de Domingo passaram vários 
apresentadores, como Márcia Peltier, Carlos Bianchinni, Maitê Proença, Ronaldo Rosas, Kátia Maranhão, Geórgia Wortmann e Carolina Ferraz (http://pt.wikipedia.org/wiki/Programa de Domingo - acesso em 25 de maio de 2008).

Outros programas jornalísticos que se destacaram na programação da tevê manchete foram o Panorama, Conexão Internacional, com Roberto D' Ávila (1983), e Cinemania (1988).

A emissora também marcou sua presença na produção de documentários como Xingu, a Terra Mágica dos Índios, de 1985, Japão, uma Viagem no Tempo, de 1986, e China, o Império do Centro, de 1987.

Em 1986, a emissora começou a ter problemas devido a um prejuízo de U\$ 80 milhões e uma dívida que já chegava a U\$ 23 milhões. No mesmo ano, a emissora enfrentou a primeira greve de funcionários.

Em janeiro de 1990, foi inaugurada a sede paulista da emissora, com equipamentos de última geração e instalações construídas especialmente para a emissora, no bairro da Casa Verde. No mesmo ano, o Banco do Brasil embargou os bens da Manchete, para garantir o pagamento de U\$ 60 milhões, em dívidas.

Em 1992, a emissora já acumulava uma dívida de U\$ 125 milhões. A saída foi negociar $49 \%$ das ações da emissora com o empresário Hamilton Lucas de Oliveira, do grupo IBF - Indústria Brasileira de Formulários, que estava envolvido no esquema de PC Farias. A crise piorou em março de 1993, com a demissão de 670 funcionários e uma greve dos que ficaram, pelo atraso dos salários. A programação saiu do ar e um slide denunciou a crise da emissora aos telespectadores.

Em 1993, a emissora voltou ao comando de Adolpho Bloch, devido ao não cumprimento do contrato pelo grupo IBF, que previa o pagamento da dívida da emissora. Em 1995, Adolpho Bloch morre. Quem fica à frente da emissora é Pedro Jack Kapeller, conhecido como Jaquito, que não consegue tirar a empresa da crise. Uma última tentativa de salvar a Manchete foi um 
contrato de arrendamento, assinado com a Igreja Renascer, que, também, não foi cumprido logo no primeiro mês e foi desfeito.

A família Bloch retomou novamente a emissora em estado terminal e procurou um comprador para pagar suas dívidas. Só com o governo, os débitos chegavam a U\$ 500 milhões e o pagamento dos funcionários estava atrasado desde 1997, quando a emissora foi vendida por U\$ 608 milhões ao grupo TeleTV, do empresário Amilcare Dallevo Júnior, em 9 de maio de 1999, dando origem à Rede TV.

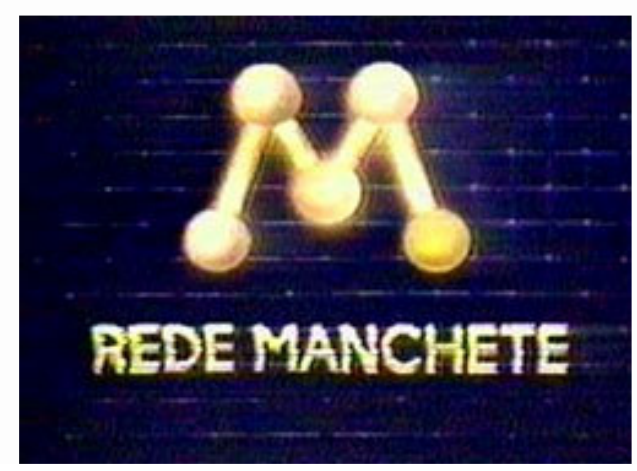

O logotipo usado pela emissora

\section{5- $O$ telejornalismo dos anos 90 até os dias atuais: Rede TV,} Globo News, Band News, Record News e allTV

Em 15 de novembro de 1999, a concessão da Rede Manchete passou para a Rede TV. É a mais nova emissora de TV aberta do país, com apenas nove anos de idade, depois da Manchete ter passado 10 meses sem pagar salários aos seus 2.500 funcionários. A emissora também enfrentou a greve de boa parte deles nas cidades de São Paulo e Rio de Janeiro. O grupo, agora dirigido por Amilcare Dallevo Júnior ${ }^{16}$, comprou somente a concessão, sem nenhum ativo da tevê Manchete e assumiu os débitos tributários e previdenciários. Nem o acervo de imagens e de novelas foi comprado pela

\footnotetext{
${ }^{16}$ Entrevista gravada em São Paulo em 9 de novembro de 2006, em São Paulo.
} 
Rede TV, tanto que os ex-donos da Manchete ainda hoje vendem as novelas e outras produções. O único compromisso que houve foi de ficar com todos os funcionários, que, nos dias de hoje, estão reduzidos a 1.200. O empresário Amilcare Dallevo Júnior foi o criador do sistema que permitiu aos telespectadores participar, via telefone, dos programas Você Decide, Fantástico e, ainda do popular tele 900.

Desde o início das transmissões, a Rede TV privilegiou o jornalismo, que sempre fez parte da grade de programação. O primeiro programa a ser exibido foi o telejornal Notícias do Brasil (ou Brasil TV), que foi apresentado pelo jornalista Julio Mosquéra, direto de Brasília, com uma entrevista exclusiva com o então presidente Fernando Henrique Cardoso. Outra atração da inauguração foi o programa A Casa é Sua - um programa com dicas e entrevistas, com a jornalista Valéria Monteiro. Na seqüência, foram sendo criados outros programas jornalísticos, como o Jornal da TV, com apresentação de Augusto Xavier e Lílian Fernandes, e, também, o TV Economia - um boletim com a jornalista Denise Campos de Toledo. Depois, teve o TV Esportes Notícias, que era um telejornal da hora do almoço. Em 2003, entrou no ar o Rede TV Esporte, às sete da noite. Logo depois, tinha o Jornal da TV, que durou apenas um ano, e foi substituído, em 2004, pelo Rede TV News, que começa às nove da noite. No final da noite, por volta de onze e quarenta, tem o Leitura Dinâmica, que é um telejornal rápido, pois segundo o presidente da Rede TV, Amilcare Dallevo Júnior:

\footnotetext{
$\mathrm{Na}$ realidade a gente tentou fazer alguma coisa que se assemelhasse um pouco com a internet, com velocidade, rapidez. Fazendo um formato diferenciado, que você, ele não tem sonora, difícil, às vezes pode ter alguma sonora pequena, mais é difícil praticamente não tem sonoras. As notícias, o texto é extremamente rápido e tudo de tal modo que o Leitura Dinâmica entra no ar as vinte pra meia noite e vai até a meia noite (DALEVO JÙNIOR, 2006).
}

A proposta do Leitura Dinâmica é ser jornal rápido, aonde a pessoa que chega em casa nessa hora tenha uma visão geral do que aconteceu no dia. Ele não entra em detalhes, em aprofundamento, é uma visão geral da notícia, englobando várias editorias, como esporte, cultura, lazer, economia e política. 
De acordo com Dallevo, o Leitura Dinâmica será o primeiro produto da emissora que vai ter uma área da internet, que vai ser o Rede TV On the mand, onde o telespectador vai ter acesso a qualquer matéria do telejornal. Será utilizada uma nova tecnologia para reduzir o tamanho do arquivo, com uma qualidade muito boa, que é H 264.

Em meados de 2002, a Rede TV também teve a experiência do Repórter Cidadão, que foi um telejornal sensacionalista, com foco nas notícias policiais, às seis e meia da tarde. Inicialmente, foi apresentado pelo jornalista José Luís Datena, que ganhou notoriedade nesta área. Depois de algum tempo, ele foi substituído pelo jornalista Marcelo Rezende, que, por sua vez, também. foi substituído por Ney Gonçalves Dias. Em 2005, o Repórter Cidadão foi tirado do ar.

\section{Redetv?}

O logotipo da Rede TV

A Globo News foi inaugurada em 15 de outubro de 1996. Foi a primeira emissora de notícias 24 horas do Brasil, via cabo. Criado pela jornalista Alice Maria, conta com os seguintes noticiários: Em Cima da Hora e Jornal das Dez. Reapresenta parte da programação jornalística da Rede Globo, como os programas Fantástico, Jornal da Globo e Globo Repórter. Possui também programas jornalísticos especializados nas áreas de cultura como Almanaque e Starte, e programas de entrevista como o Espaço Aberto (http://pt.wikipedia.org/wiki/Globo News - acesso em 25 de maio de 2008). Isto mostra que o canal não segue a tônica de estar, o tempo todo, exibindo noticiários. $O$ investimento previsto para a implantação da Globo News foi de $R$ 
410 milhões (PATERNOSTRO, 2006: 32). No documento que orientou a implantação do novo canal, algumas premissas, como uma inovação nos processos de cobertura jornalística, se destacam. O primeiro logotipo, criado pelo designer Hans Dunner, traduz a idéia de um canal que segue em direção ao futuro, para o alto: "como uma flecha em direção ao céu, fiz a inclinação da letra $\mathrm{L}$, de Globo, e da letra $\mathrm{N}$, da palavra News, dando à marca uma dinâmica de velocidade", disse ele (PATERNOSTRO, 2006: 42). Num primeiro momento, a equipe foi composta por um grupo de 80 a 100 profissionais. Os profissionais da área técnica foram recrutados em cursos de jornalismo e de rádio e TV. O time de jornalistas foi constituído por profissionais recém-formados, jornalistas muito experientes e um grupo intermediário, com alguma experiência. Foi o que a diretora do canal classificou de encontro de olds com os news. Os novos profissionais foram chamados, por ela de multi, de multifunção, "porque iam aprender a fazer praticamente tudo no telejornalismo: pautar, produzir, escrever, editar e, os com talento para o vídeo, também, a fazer reportagem e apresentar jornal", declarou Alice-Maria (PATERNOSTRO; 2006; 59). Uma mudança técnica essencial para o ritmo da Globo News foi colocação do controle do teleprompter com o apresentador. $O$ departamento de engenharia usou um pedal de guitarra elétrica, escondido atrás da bancada, que permitiu que os apresentadores fizessem os movimentos do equipamento $e$ controlassem o seu próprio ritmo de leitura. Outra inovação proposta pela Globo News foi a implantação do script eletrônico, que pôs fim ao script de papel, pois tendo edições de hora em hora, seria inviável, em termos de gasto de papel. Aos poucos, toda a equipe se adaptou e a leitura do script passou a ser feita através do monitor do teleprompter, que passou a conter todas as informações (técnicas e texto) do lado direito ${ }^{17}$.

A BandNews foi inaugurada em 19 de março de 2001, pelo Grupo Bandeirantes de Comunicação. Trabalha com dinâmica de exibir jornais durante as 24 horas do dia, e, para isso, utiliza toda a estrutura da rede de emissoras de rádio e televisão do grupo, pois não tem produção própria. Utiliza o material proveniente do grupo, que é reeditado e exibido ininterruptamente.

\footnotetext{
${ }^{17}$ Antes disso, apenas as informações textuais, para o apresentador, eram colocadas do lado direito do script e, do lado esquerdo, eram colocadas as informações técnicas.
} 
Das agências de notícias nacionais e internacionais, também são aproveitados materiais informativos. Sua equipe é formada de apresentadores, produtores e editores. A programação jornalística ininterrupta é composta de blocos noticiosos de 15 minutos, com atualização contínua. As notícias do dia, os indicadores e a prestação de serviços são a tônica do canal, para manter o telespectador informado. A emissora conta com duas afiliadas, uma no Rio de Janeiro e outra em Pernambuco. A BandNews é transmitida somente pela tevê a cabo e para os assinantes da Uol (http://pt.wikipedia.org/wiki/Band News acesso em 25 de maio de 2008).

A allTV foi criada, oficialmente, em 13 de maio de 2002, pelo jornalista Alberto Luchetti ${ }^{18}$ Neto, mas as primeiras experiências começaram em abril do mesmo ano. O investimento inicial foi de US\$ 2 milhões.

O criador da emissora, assim como Assis Chateaubriand Bandeira de Melo, que implantou a TV no Brasil em 1950, depois de conhecer emissoras nos EUA, também teve sua inspiração em emissoras estrangeiras, como a Citytv, de Toronto, no Canadá e a New York One, de Nova lorque, nos Estados Unidos. Ambas são emissoras com a programação voltada para o público local, com prestação de serviço e muito dinamismo. Mas, ao contrário das fontes de inspiração canadense e americana, a proposta da allTV é única:

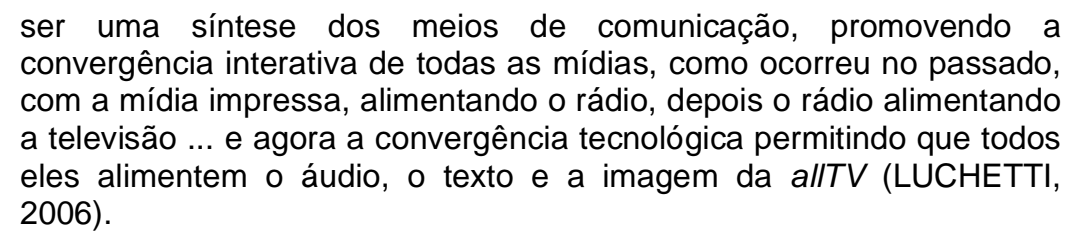

O nome allTV, ao contrário do que muitos críticos dizem, não significa Alberto Luchetti TV. É sim uma alusão ao termo inglês all, que significa tudo, totalidade, todos e inteiro, numa referência à convergência das mídias, através da emissora. Para o seu criador, a inspiração foi fazer "tudo ao mesmo tempo, agora, o tempo todo". Na allTV, é possível sentir a instantaneidade do rádio, usar as informações do impresso e transmitir tudo isso através da internet, com imagens em movimento, e, ainda, interagir com os espectadores/internautas, que também vêm configurar uma nova modalidade de receptores. Luchetti

\footnotetext{
${ }^{18}$ Entrevista realizada em São Paulo em 29 de março de 2006.
} 
afirma que esta nova modalidade de comunicação é a soma de todas as experiências profissionais pelas quais ele passou, no decorrer de sua carreira jornal, rádio e tevê:

Reuni as características mais importantes que eu vejo em cada veículo: no jornal, o que eu vejo é o conteúdo mais apurado, mais aprimorado, mais robusto; no rádio, o que eu vejo como característica brilhante é a agilidade e a instantaneidade; e a televisão, o que ela tem de mais interessante, é a plástica, é a imagem (LUCHETTI, 2006).

Considerada pelo seu criador como a primeira TV da internet do Brasil, por seu diferencial de interatividade e de funcionamento, durante as 24 horas do dia, a nova emissora não precisou, segundo Sérgio Kulplas, inventar uma linguagem do nada, nem transformar pessoal de rádio em pessoal de TV, como fez Chateaubriand, há mais de 50 anos. Ao contrário, "a allTV forja sua linguagem, transformando profissionais de TV em pessoal de Net-rádio, com imagem". Já o diretor geral e criador da TV da internet, Alberto Luchetti Neto, analisa os profissionais da allTV como uma geração multimídia, pois a grande maioria nunca trabalhou em veículo de comunicação e é oriunda das faculdades de comunicação.

São profissionais dispostos a enfrentar grandes desafios, como improvisar no ar, além de mediar programas e também interagir com os espectadores/internautas. Eu faço aqui em seis meses o que as faculdades levam quatro anos, ensinando mais na prática do que na teoria. É o que eu chamo de sinergia, pois este profissional escreve, faz reportagem, edita. Ele traz material e ninguém mexe no material dele (LUCHETTI, 2006).

O termo "geração multimídia" foi usado por Luchetti, numa alusão à evolução do profissional de comunicação ocorrida nos últimos trinta anos. Ele relembra o tempo em que trabalhava no jornal Estado de São Paulo:

no ano de 1972, quando eu trabalhava no Estadão, eu tinha que escrever a matéria naquelas máquinas Olivetti, com três folhas de carbono; em 1988, iniciou-se o processo de informatização do jornal; aí, eu tinha que fazer o título, o texto final, pois foi abolido o revisor, tive que apurar melhor o meu texto $e$ isso foi bom para mim, profissionalmente (LUCHETTI, 2006).

A proposta é inovadora, até pela condição que coloca e confirma a allTV como a primeira TV da internet não só do Brasil, como também do mundo, fato que rendeu ao seu criador um certificado de direito autoral internacional, na Biblioteca Nacional. Mas a emissora é o que poderíamos chamar de mídia de 
alternativa ou new mídia, pois não se trata de emissora de TV convencional, tampouco de uma concessão pública de radiodifusão. É um veículo da internet, mas traz o caráter inovador da convergência de várias mídias, num único ponto de encontro. Acrescenta, ainda, ao receptor (espectador/internauta) a possibilidade de interagir com o emissor.

Mas, o que significa interatividade? A interatividade pode, num primeiro momento, ser resumida como "diversas formas criativas de se trabalhar, usando várias maneiras de interação em uma apresentação, onde o emissor consiga transmitir a mensagem para 0 receptor" (www.geocities.yahoo.com.br/interatividade.htm - acesso em 30 de março de 2006). A interatividade pode ser "reativa", quando segue padrões preestabelecidos e/ou segue determinadas regras existentes no programa. Exemplo disso é o vídeo game. Pode, também, ser "mútua", que funciona exatamente de forma contrária à reativa. Proporciona uma comunicação com trocas reais, criativa e aberta. Nela, a influência e as interferências influentes agem como um todo. Como exemplo, temos os Chats, os formulários, etc. A allTV se enquadra nesta segunda forma de interatividade.

A TV da internet também pode ser enquadrada no conceito utilizado por Joly, onde a pesquisadora trata a interatividade mútua como a bidirecionalidade, e cita a emissora como um exemplo, pois:

\footnotetext{
utiliza a tecnologia da televisão somada à versatilidade da Internet, e transmite uma programação baseada em variedades, entretenimento, serviço e informação; os apresentadores permanecem ao vivo, interagindo com o computador, para responder mensagens escritas ou faladas; se o usuário possuir uma "webcam", pode participar da programação. (JOLY, 2005)
}

Para chegar ao formato da allTV, seu diretor geral, Alberto Luchetti, usou sua experiência de 30 anos de atuação em diversos veículos de comunicação, como os jornais Folha de S. Paulo e Estado de S. Paulo, as rádios Jovem Pan e Bandeirantes, e os canais de televisão Rede Bandeirantes, Rede Globo, TV Jovem Pan e Canal 21, tendo sido, as duas últimas, as primeiras emissoras jornalísticas de UHF da cidade de São Paulo.

A allTV também é considerada pela wikipédia como a primeira emissora de televisão no formato "crossmedia" do Brasil. Conceitualmente, o que chamamos de "crossmedia" nada mais é do que a possibilidade de uma 
mesma campanha, empresa ou produto utilizar simultaneamente diferentes tipos de mídia: impressa, TV, rádio ou Internet.

O mais novo canal de notícias do Brasil é a Record News - a primeira rede aberta de televisão, com programação segmentada. A inauguração da emissora aconteceu em 27 de setembro de 2007, como parte das comemorações dos 54 anos da Rede Record - emissora que compõe um grupo de comunicação, comandado pelo pastor Edir Macedo da Igreja Universal do Reino de Deus. Foram investidos US\$ 7 milhões para equipar o novo canal, que conta com 150 jornalistas e outros 100 profissionais. A base jornalística da emissora funciona em uma redação de $1.000 \mathrm{~m}^{2}$, que está dividida em uma newsroom, com 60 posições, e um estúdio para gravação.

A Record News ocupa o lugar de uma outra emissora do grupo - a Rede Mulher, que foi extinta, para dar lugar ao novo projeto. A concepção da nova emissora ocorreu depois de uma visita dos diretores da emissora à sede mundial da CNN, em Atlanta, nos Estados Unidos.

De acordo com o presidente da Record, em entrevista ao site Portal Imprensa, o novo canal será um meio de tirar maior proveito dos produtos jornalísticos da emissora e fortalecer a marca Record, tornando-a ainda mais conhecida.

Atualmente, a Record News exibe 19 horas de programação ao vivo, das 6 da manhã até 1 hora da madrugada. O diferencial da emissora, em relação às suas antecessoras, é dispor ao grande público, em sinal aberto, um canal segmentado de notícias.

O carro chefe da emissora é o telejornal Record News Brasil, que vai ao ar, diariamente às $21 \mathrm{~h}$,e é apresentado pelo jornalista Eduardo Ribeiro.

A maior parte dos programas é gerada de São Paulo, mas existem alguns telejornais regionais produzidos em Salvador, Rio de Janeiro, Porto Alegre, Araraquara e Miami. Ao todo, são produzidos, pela nova rede, 28 programas, entre nacionais e regionais, todos de cunho jornalístico. 


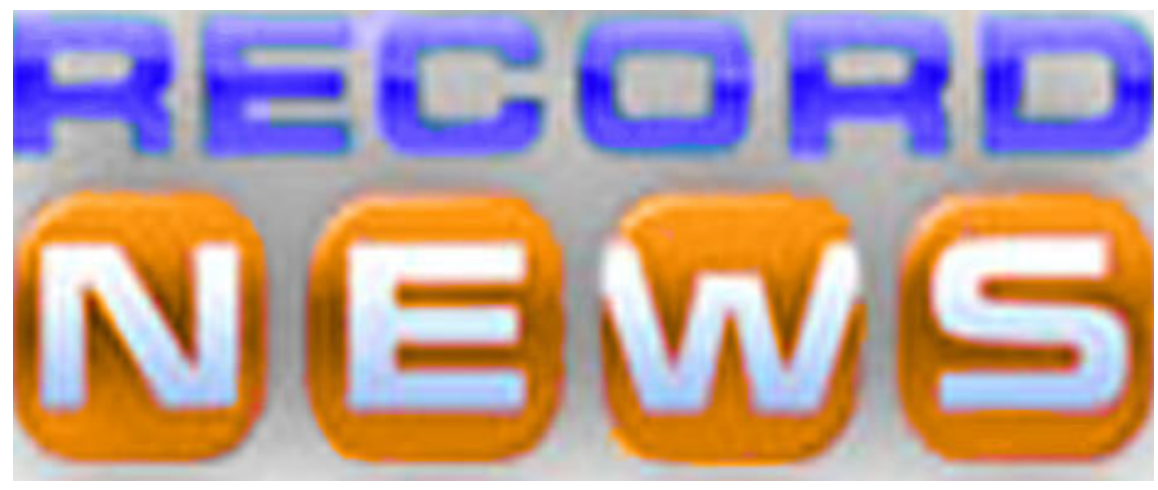

O logotipo da nova emissora

\section{Capítulo 2 - Aspectos históricos dos Profissionais do Telejornalismo Brasileiro}

\subsection{Primeira Fase - Radiofônica - décadas de 1950 e 1960}

A televisão fez com que todo mundo passasse a ver mais e melhor MELLO E SOUZA

A televisão foi implantada no Brasil em 1950, utilizando toda a tecnologia norte-americana. As câmeras da primeira emissora, que foi a Tupi, eram cinematográficas, em preto e branco, sem som, e os primeiros telejornais eram improvisados, ao vivo, com poucas imagens, em preto e branco, para ilustrar algumas notícias frias sobre o dia-a-dia da cidade de São Paulo. Não havia ainda sido desenvolvido o conceito de reportagem, pois muitas vezes o cinegrafista ia sozinho colher as imagens, que iriam ilustrar o telejornal (Sampaio, 1971).

Nesta década, pouco se evoluiu, pois ainda vivia-se sob o impacto desta nova tecnologia, que mais parecia um "rádio com imagens". As câmeras usadas eram as Bell \& Howell - uma câmera de corda, que tinham três objetivas. Era preciso girar a objetiva e colocavam-se os visores, relativos a 
cada objetiva. Dava-se corda na câmera e ela rodava, mais ou menos, 30 segundos. Depois rodava-se novamente e, geralmente, essas câmeras operavam com rolo de filme de 100 pés, (30 metros de filme), que correspondia, em tempo, a 2 minutos e meio de imagem. Em seguida, este filme negativo era revelado, na Rua 7 de abril, onde ficava o laboratório e, a seguir, enviado para a emissora no Sumaré. Para ser exibido, o filme tinha que ser revertido no telecine, através da chave de reversão, mas, a qualidade da imagem era preta demais, pois não havia possibilidade de ajuste e os meios tons desapareciam. Mais tarde, surgiu o filme reversível, que dava uma qualidade melhor. Quando havia a necessidade de gravar o som, essa câmera não resolvia, então usava-se uma Cine Kodak Especial, que era colocada no tripé. Mas isso só em casos especiais, como o discurso do prefeito, governador ou uma personalidade. Além disso, eram usados, também, no telejornal os slides 35 milímetros do projetor no telecine, quando se falava de algum personagem. Depois de algum tempo começaram a surgir às câmeras Mitchell, que tinham um chassi de 4000 pés, com capacidade para 12 minutos de captação (Fanucchi, 2006).

Os primeiros profissionais a serem convocados para trabalhar na televisão foram os radialistas, visto que a tecnologia, até então, era muito parecida, pelo menos no diz respeito ao sistema de radiodifusão de som e imagens. As exigências para se trabalhar na televisão eram mínimas, pois ninguém sabia como fazer televisão naquele momento. Os radialistas, devido à voz e ao poder de improvisação, chegaram ocupando as bancadas dos primeiros telejornais. Era quase que função obrigatória aos que trabalhavam nas emissoras de rádio das Associadas cumprirem uma etapa de trabalho, também na televisão. Houve uma espécie de convocação, por parte Chateaubriand, para os profissionais do grupo aderirem ao novo veículo de comunicação, que era a TV Tupi - Canal 4, de São Paulo (Fanucchi, 2006).

Nesta fase, de acordo com Mário Fanucchi ${ }^{19}$, a programação só começava às 8 da noite. Durante o dia, eram realizados os ensaios, a produção e marcação das câmeras. Segundo Fanucchi, "o estilo do jornal era quase um jornal de rádio, lido diante da câmera. Não tinha teleprompter, o jeito era pegar

${ }^{19}$ Entrevista gravada em São Paulo em 26 de outubro de 2006. 
as laudas e ler olhando ora para a câmera, ora para a lauda." O apresentador tinha que passar credibilidade, como foi o caso do primeiro apresentador do Imagens do Dia, Rui Rezende:

Ele tinha um tipo muito sóbrio, assim como apresentador. Muito
circunspecto até. Talvez, por isso, achavam que ele era muito pedante.
Ele não tinha experiência, a não ser da tentativa de ser um
apresentador porque não havia nenhum modelo a vista... não se via
jornal na televisão. O modelo que nós tínhamos era o Cine, o Jornal da
Tela, com o locutor falando offs na voz de padre. O modelo na forma
de apresentação era o radiojornal, praticamente (FANUCCHI, 2006).

A equipe era pequena, havia um diretor de jornalismo, que na época era o Armando Figueiredo, e também um redator, que era o Gonçalo Parada. "Ele era o homem que fazia o texto pro rádio e passou a fazer o texto pra televisão", confirmou Fanucchi. Não houve nenhuma espécie de treinamento, nem preparação para se fazer telejornal nesta época. O que houve foi muita improvisação e muita vontade, por parte dos telejornalistas, de fazer a coisa bem feita e agradar o telespectador, que, naquele momento, era limitado e elitizado.

Com o tempo, surgiram os primeiros repórteres da televisão brasileira, o José Carlos de Morais - Tico-tico e o Carlos Espera. Os dois, inclusive, eram rivais, pois trabalhavam competindo, relatou Fanucchi: "um queria fazer o furo sobre a matéria do dia, para superar o outro, e eles faziam uma briga de bons esportistas."

Havia muita improvisação, principalmente na escolha dos apresentadores do telejornal, como aconteceu com Mappin Movietone, que era patrocinado pelo Mappin e já copiava o modelo americano até na música de abertura; "entrava o prefixo daquele Jornal da Tela da Fox, era uma música bem marcante," recordou Fanucchi. O apresentador era Roberto Corte Real um produtor musical, locutor, que logo passou a fazer esse jornal. "Acidentalmente, quando ele tirou férias, eu precisei fazer o jornal também, porque é como eu digo, havia muita improvisação", relatou Fanucchi. Esse telejornal era parecido com o Imagens do Dia, só que tinha menos recursos, porque era às 9 da noite e não havia tempo de produzir material e revelar e montar, "então era um tipo de jornal de rádio lido mesmo, o típico formato era leitura de textos", concluiu Fanucchi. 
Nesta fase, surgiu o conceito de merchandising na televisão, pois até então, todas as marcas que eventualmente pudessem identificar um produto na televisão eram cobertas com fita crepe. Mas quando entrou o patrocínio para o Mappin Movietone (além do próprio nome do telejornal) de uma fabrica Suíça de relógio, a direção da emissora resolveu implantar essa nova idéia dentro do telejornal, "Eles acharam que ficava bem, logo depois de terminar o jornal, eu olhar pro relógio e falar: esse é o meu Eterna Matic, sempre na hora certa, sempre, eu confio nele e tal..."

Depois disso, surgiu o Repórter Esso, que também era patrocinado pela Esso. O programa, que no rádio fazia muito sucesso, na voz de Dalmácio Jordão, teve a sua primeira versão televisiva em São Paulo, na voz de Kalil Filho. Depois, a versão carioca, na voz de Gontijo Teodoro. Mais tarde, o Recife teve a sua versão, com Edson Almeida. Minas Gerais, de acordo com Carlos Fabiano Braga, também teve o seu Repórter Esso, a partir de 1957, com Luís Cordeiro, na tevê Itacolomi. Esse conceito de telejornal patrocinado durou mais de uma década, vindo cair por terra só no final da década de 60.
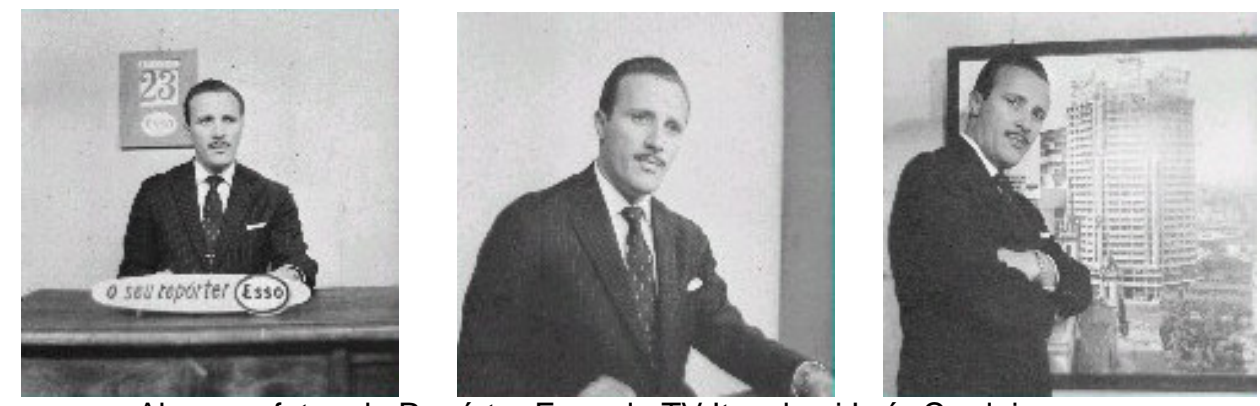

Algumas fotos do Repórter Esso da TV Itacolomi Luís Cordeiro Acervo de Carlos Fabiano Braga

Outro que veio do rádio para televisão, nesta fase, foi o jornalista Fábbio Peres $^{20}$, que recebeu um convite do próprio repórter Esso, Kalil Filho, para trabalhar como redator, mas continuou no rádio também. Depois, em 1962, formou-se em publicidade e acumulou as três funções: rádio, televisão e publicidade. Ele confirma o caráter pouco seletivo que a televisão tinha e a circulação dos profissionais tanto no rádio, como na televisão:

É todo pessoal ao mesmo tempo em que fazia rádio, fazia televisão, não havia uma distinção muita clara, e durante muito tempo o que fez

${ }^{20}$ Entrevista gravada em São Paulo em 12 de dezembro de 2006. 
na televisão foi o rádio televisionado. Existiam poucos recursos até pra gravar programas, era tudo ao vivo, e a minha área estava sempre ligada ao jornalismo e a alguns programas de variedade. Então não tive muita complicação de me adaptar (PERES, 2006).

$\mathrm{Na}$ televisão, Peres fez de tudo. Foi redator, apresentador, locutor noticiarista, editor de texto e chegou até, nos anos 80 , ao cargo de editor-chefe do Jornal Nacional. "Basicamente, na primeira fase, fui mais apresentador, porque, naquela época, existia uma distinção muito severa entre o que era parte redacional e quem apresentava", explicou Peres. Ele acrescenta ainda um dado importante a respeito da confirmação de o Repórter Esso ter sido o início da implantação do modelo americano no Brasil, ao afirmar que ele foi a grande baliza do noticiário, pois:

Inclusive, eu tenho até hoje comigo uma Manual do Repórter Esso e que eram as bases do jornalismo que se faz hoje. Antes do Repórter Esso, era uma coisa, depois do Repórter Esso, nós temos aquele jornalismo sem adjetivo, linguagem enxuta, frases curtas. Mas tudo isso já era preconizado pelo Repórter Esso (PERES, 2006).

Com relação aos repórteres, Peres informa que a tecnologia mudou, porque favoreceu a reportagem. Segundo ele, hoje é possível sincronizar imagem e som, montar as sonoras com mais agilidade, facilitando o surgimento do repórter profissional. Ao contrário do repórter, que considera testemunhal, como eram o Tico-tico e o Carlos Espera: "eram repórteres natos, mais eles falavam como testemunha do fato, eles tinham credibilidade, era uma narração de caráter quase que pessoal". Ainda com relação aos pioneiros da reportagem televisiva no Brasil, Peres recorda uma passagem em que Tico-tico era considerado muito atrevido e no afã de uma entrevista, ele quebrou o dente de uma pessoa com microfone. O repórter era uma espécie de parte da notícia: "o Carlos Espera, por exemplo, ficava dormindo no próprio local do acontecimento, ele era repórter full time, não tinha essa de escala ou seguir uma pauta", informou Peres.

No caso de Fernando Barbosa Lima ${ }^{21}$, mesmo com a mãe querendo que ele fosse advogado, partiu primeiro para um teste vocacional, com o psicólogo argentino Peri Lopes. $O$ teste revelou que ele poderia fazer algumas coisas como arquiteto, escritor, pintor ou jornalista, menos ser advogado. Mas o prestígio e os contatos da família foram fundamentais para o início da carreira:

${ }^{21}$ Entrevista gravada no Rio de Janeiro em 20 de novembro de 2006. 
"eu comecei criando, já dirigindo programas, eu não passei por nenhuma escola, porque como eu conhecia bem, eu dominava bem o desenho, eu dominava bem o texto. Se você juntar bem essas coisas, acaba dando em televisão". Sua primeira criação para a televisão foi o Preto no Branco - um programa de entrevista com o Sargentele, fazendo as perguntas em off: "nós nunca entramos na vida pessoal de ninguém, nós entrávamos sempre no pensamento sobre a vida profissional". A versão paulistana deste programa foi ao ar pela tevê Record e chamou-se Pingos nos Is. Depois de um tempo, ele foi convidado pelo Edson Leite para ser o diretor de jornalismo da tevê Excelsior, que estava se formando. Na Excelsior, Lima teve a oportunidade de criar o Jornal da Cidade - um telejornal que entrava no ar às 8 da noite. Mas, a sua grande criação, foi o Jornal de Vanguarda, que entrava no ar às 10h30 da noite.

Não poderia ser um telejornal como era feito naquela época, que era com um locutor, uma câmera na frente e um pequeno estúdio, com o nome do patrocinador na frente, quer dizer na verdade um estúdio de rádio com uma câmera lá dentro, não tinha nada de televisão naquilo (LIMA, 2006).

O jeito que teve foi ousar e colocar no estúdio ao vivo mais ou menos oito ou nove apresentadores, às vezes chegava a dez apresentadores, no Jornal de Vanguarda. Entre os apresentadores estavam o Vilas Boas Correa, Nilton Carlos (comentarista internacional), Milôr Fernandes, Sergio Porto - 0 Stanislaw Ponte Preta, Borjalo (fazendo bonequinhos), Appe (que, por trás de uma tela translúcida, fazia desenho da caricatura de político ou do personagem que se estava falando), Luís Jatobá, Fernando Garcia, Cid Moreira, João Saldanha, Glauber Rocha e Gilda Bilha. Era uma verdadeira loucura, um telejornal com mais de dez pessoas dentro do estúdio, mas tudo era coordenado, de forma a que todos dessem o seu recado. O Jornal de Vanguarda foi premiado na Espanha, onde concorreu na Eurovisão com os grandes telejornais do mundo inteiro, sendo que ficou finalista com o jornal da BBC e ganhou. Mas a vida do Jornal de Vanguarda não foi tão simples assim:

O Jornal de Vanguarda entrou na Excelsior. Aí veio à ditadura. Com a ditadura, nós começamos a ter problemas, nós saímos da Excelsior. Fomos da Excelsior para a TV Tupi ficamos um ano na TV Tupi. Da Tupi, fomos para a TV Globo. O Walter pediu pra levar o jornal pra TV Globo, Walter Clark. Da TV Globo, nós saímos passamos rapidamente pela TV Continental. Depois, voltamos para TV Excelsior, e aí, fomos 
pra TV Rio e acabamos na TV Rio. Acabamos porque, acabamos exatamente quando veio o Al-5. Quer dizer, ele começou em 63 e foi até o Al5, em 68. Ele ficou cinco anos ano ar. Eu não acredito que nenhum programa no Brasil tenha recebido tantos prêmios quanto o Jornal de Vanguarda (LIMA, 2006).

Uma das grandes marcas do Jornal de Vanguarda foi a liberdade de expressão, pois, mesmo naquela época, cada um dos oito ou dez apresentadores fazia seu próprio texto, fazia seu comentário. Era uma proposta muito livre, muito aberta e o público percebia isso, mas os militares não. $\mathrm{Na}$ saída definitiva do Jornal de Vanguarda do ar, Lima resumiu seu sentimento numa única frase: "cavalo de raça, a gente mata com um tiro na cabeça."

O jornalista Carlos Alberto Ballut Vizeu'22, desde 1962, ainda muito jovem, começou a trabalhar no rádio, influenciado pelo pai e pelo tio ${ }^{23}$, que eram repórteres do rádio e depois foram trabalhar em tevê. "O que me atraiu foi a televisão, porque a minha família era já ligada ao meio. O pai, o tio, então, o ambiente na minha casa era permanentemente de televisão. Televisão e rádio." Apesar de ter se formado em direito, nunca atuou na profissão. Na verdade, esta foi a condição imposta pela mãe para deixá-lo trabalhar no rádio e depois na tevê (que ele não abandonasse os estudos e tivesse um diploma universitário). No começo, ele acompanhava o tio, quando o mesmo fazia reportagem. "Ele me levava porque fazia muito gosto que eu fosse como ele. Eu ficava lá assistindo as reportagens, no caminhão de externa (...) daí eu comecei a viver aquilo tudo e comecei a me interessar por televisão." Antes de ir trabalhar na televisão, aprendeu de tudo no rádio, foi coordenador de horário, locutor noticiarista, redator, repórter e produtor, pois segundo seu tio, "quem não sabe fazer, não sabe mandar." Em 1963, teve sua primeira chance na tevê Continental, fazendo um programa chamado Gente e Notícia, aos domingos. Tratava-se de uma revista semanal, com os principais acontecimentos, e contava com a participação de pessoas respondendo no estúdio. "Dava-se a notícia e cortava-se para o entrevistado, o personagem da notícia." Para ele, a

\footnotetext{
${ }^{22}$ Entrevista gravada no Rio de Janeiro em 16 de maio de 2008.

${ }^{23} \mathrm{Na}$ dissertação de mestrado de Flavia Bazan Bespalhok denominada $A$ prática da reportagem radiofônica na emissora Continental do Rio de Janeiro é possível localizar Ary Vizeu e Carlos Palut como o pai e o tio de Carlos Alberto Vizeu respectivamente. O pai Ary Vizeu que trabalhou em rádio desde 1930 passando pelas emissoras Guanabara, Nacional, Mayrink Veiga, entre outras. O tio Carlos Palut desenvolveu a experiência da reportagem volante na rádio Continental, com base no estabelecimento do tipo de radiojornalismo que temos na atualidade.
} 
tevê Continental foi uma grande escola, apesar de todos os problemas administrativos que tinha, como atrasar o pagamento e a falta de pessoal. "Você tinha que substituir às pressas um companheiro, às vezes, num setor que não era aquele em que você estava escalado para trabalhar, e você tinha que fazer corte, fazer direção de tevê de um programa que ia entrar no ar daqui a três minutos." Para Ballut Vizeu, a grande mudança tecnológica foi o vídeotape: "a televisão se divide, vamos assim dizer, antes do vídeotape e depois dele." Ele recorda que, em 1959, a tevê Continental comprou o primeiro aparelho de vídeo - tape, numa feira de equipamentos promovida pela Ampex, no Rio de Janeiro. Reforçando a premissa de que nos anos 50 e 60, os profissionais eram formados na prática, Ballut Vizeu revela as necessidades daquela época, para lidar com as novas tecnologias: "enfrentando, tendo que se adaptar, porque o Brasil é um país que não tinha literatura nenhuma, hoje a coisa melhorou bastante." O grande trabalho de Ballut Vizeu foi no Jornal de Vanguarda. Ele foi produtor e diretor daquele que foi a grande revolução da televisão nos anos 60, pois ele acompanhou o Jornal de Vanguarda por todas as emissoras. Segundo ele, "os telejornais eram todos feitos com um locutor sentado, tinha uma mesa na frente, um globo e uma tabuleta com o nome do anunciante, e o locutor dando as notícias, como se estivesse num estúdio de rádio." Mas o trabalho não era nada fácil, devido à censura, que estava o tempo todo marcando em cima do Jornal de Vanguarda, conforme vimos anteriormente:

A gente passou por todas as estações. Pulava igual pipoca. Começamos na tevê Excelsior, isso em 63. Depois fomos pra tevê Tupi, ficamos lá um ano, um ano e pouco. Depois fomos pra tevê Globo, depois da tevê Globo, voltamos pra tevê Excelsior. Da tevê Excelsior, fomos pra tevê Continental, e da tevê Continental fomos para tevê Rio, onde terminou o jornal (BALLUT VIZEU, 2008).

Para ele, os telejornais brasileiros passaram por três fases distintas: "tem os pioneiros, como Repórter Esso, Telejornal Pirelli e Imagens do Dia. Depois tem o Jornal de Vanguarda, que foi a grande revolução do telejornalismo, e, depois, a terceira fase, que foi a fase do Jornal Nacional, indiscutivelmente, que foi a fase definitiva na televisão brasileira." Uma das recordações que Ballut Vizeu guarda do tempo do Jornal de Vanguarda está relacionada com a improvisação constante que os profissionais tinham que fazer de última hora, porque, 
naquela época, os equipamentos de tevê eram movidos através de válvulas. Ele relatou que, muitas vezes, durante o Jornal de Vanguarda na TV Continental, as câmeras eram tão velhas, que era preciso deixar uma câmera ligada mostrando a rua, para o caso de uma outra pifar e ter que cortar, repentinamente, até poder mudar a posição das outras e retomar o telejornal.

Paulo Roberto Leandro ${ }^{24}$ começou a trabalhar em tevê graças à convivência com o colega de faculdade, e já profissional, Walter Sampaio, que na época era diretor de jornalismo da Excelsior. Tendo trabalhado em quase todas as funções dentro de uma redação de tevê, Leandro foi apresentador, repórter, editor-chefe, chefe de reportagem e diretor de jornalismo. Ele trabalhou, a partir de 1968, na tevê Tupi, depois na Bandeirantes, Cultura, Globo, Rede TV e Cultura, atualmente. Para ele, o que era necessário, naquela época, para conseguir um trabalho em televisão era ter relações com as pessoas que já estavam lá, como foi o caso dele, porque não haviam profissionais especializados em telejornalismo, devido à novidade que ainda era a televisão. Os profissionais aprendiam na prática ou levavam os conhecimentos que tinham do rádio e do impresso.

O jornalista Demétrio Costa ${ }^{25}$, apesar de não ter conseguido cursar jornalismo na Eca, como ouvinte, já era registrado no Ministério do Trabalho. Acabou cursando Geografia, por ter muita coisa em comum com a área. O veto ao seu pedido na Eca foi feito pelo diretor da Escola e professor Freitas Nobre. Isso não impediu Costa de dar continuidade à sua carreira, que fora iniciada aos 15 anos de idade, como redator noticiarista, na Rádio Bandeirantes, em 1963: "eu ia pra lá de madrugada, não podia bater ponto, aquelas coisas todas". Ele também trabalhou na Agência Noticiosa Internacional UPI, foi assessor de imprensa na Prefeitura Municipal de São Paulo e também na Secretaria de Estado da Cultura. Teve também passagem pela tevê Bandeirantes e tevê Cultura de São Paulo. Em 1967, quando a Bandeirantes montou a televisão - o canal 13 -, o convite aos profissionais do rádio para trabalhar, também na emissora, foi imediato. $O$ único requisito era ter experiência em rádio e ter um bom texto. Os telejornais eram o Jornal da Hora do Almoço e o jornal da noite - Titulares da Notícia. A produção do noticiário,

\footnotetext{
${ }^{24}$ Entrevista gravada em São Paulo em 9 de novembro de 2006.

${ }^{25}$ Entrevista gravada em São Paulo em 8 de novembro de 2006.
} 
de acordo com Costa, era baseada no "gilete press", pois "recortava-se o que era importante, que tinha saído no jornal da cidade e o pessoal mandava o cinegrafista". O resultado era uma filmagem e um tal "relatório anexo", onde os redatores não encontravam nada além do que havia saído no jornal do dia, e tinham que correr atrás de mais informações para editar a matéria e, "às vezes, a gente conseguia uma informaçãozinha adicional, pra esquentar um pouquinho aquele fato", relembrou ele, pois naquela época ainda havia a figura do repórter. É o que Costa classificou como condições ainda precárias de produzir telejornalismo naquela fase. Na sua passagem pela tevê Cultura, começou como editor, e depois, em razão do que acabou acontecendo com o jornalista Vladimir Herzog, assumiu a direção de jornalismo da emissora. Ficou como diretor de jornalismo da tevê Cultura, de 75 até 78 :

\footnotetext{
Um período realmente muito gratificante pra mim. Difícil como sempre, pela situação, o departamento tava mais pra se desmantelar, mas a gente conseguiu dar a volta, e claro que foi um período complicado de se trabalhar, mas conseguimos fazer tanta coisa boa lá! (COSTA, 2006).
}

O momento foi, politicamente, muito difícil e a Cultura tinha um agravante, porque dependia de verbas do Estado. Principalmente depois do que aconteceu com o Vladimir Herzog, que foi prestar depoimento no Doi-Cod e foi torturado até a morte, causando muita revolta e indignação da população, em 1975. A equipe que sobreviveu depois do caso Vlado passou a conviver com aquela situação, desafiando, constantemente, a própria censura: "não podia falar sobre manifestação, mas a gente inventava uma matéria sobre o trânsito complicadíssimo do dia, e claro mostrava congestionamento, mas lá pelo fundo apareciam os manifestantes". Foi a maneira que a equipe encontrou de dar alguma coisa, enquanto os outros canais simplesmente silenciavam. Nesta época, a tevê Cultura tinha dois telejornais importantes, o Hora da Notícia, que ía ao ar às 8 horas da noite - que era um telejornal factual, com pequenas reportagens e uma cobertura noticiosa local, nacional e internacional e às 9 horas da noite tinha um telejornal mais pretensioso, o Hora da Notícia Reportagem - que procurava fazer um Globo Repórter diário, onde eram eleitos três temas, local, nacional, política e internacional, com reportagens trabalhadas em profundidade e interpretativas. Mesmo sendo uma época de condições precárias, os telejornalistas já buscavam padronizar alguns 
procedimentos e criar algumas regras básicas, mesmo sem ter, ainda, um manual: "não era assim um manual completo, mas, de repente, a gente discutia muito nas reuniões de pauta. Então, dava pra, de certa forma, ir balizando um pouco mais", comentou Costa. Entre as atividades desenvolvidas por Costa, durante sua passagem pela tevê Cultura, não podemos deixar de destacar a participação na criação do Vox Populi - um programa de entrevistas, onde se fazia uma boa pesquisa, tinha-se sempre um bom entrevistado e uma boa montagem. As perguntas eram gravadas antecipadamente, por pessoas comuns ou não, e eram exibidas para o entrevistado, durante a gravação do programa: "foi o primeiro programa em que o Lula se projetou nacionalmente." O programa gravado com o Lula aconteceu em maio de 78, quando estava sendo deflagrada a greve dos metalúrgicos. Os jornalistas Figueiredo e Lemos, do Jornal do Brasil, pediram para acompanhar a gravação e foi feito um acordo para que eles divulgassem a matéria no domingo, ressaltando alguns pontos do programa. Mas a publicação da matéria caiu como uma bomba, porque às 10 horas da manhã do domingo, a Polícia Federal foi até a emissora para apreender o programa. Foi só depois do domingo todo de negociações com o Palácio do Governo, a Secretaria de Cultura, e a direção da emissora que a Polícia Federal liberou a exibição do programa, com uma condição: antes teria que divulgar uma nota do Ministério do Trabalho, informando que haviam retornado as negociações para o término da greve.

O jornalista Luís Fernando Mercadante ${ }^{26}$, que teve toda a sua carreira voltada para o impresso até 1969, foi parar na televisão devido a um convite do amigo Luiz Edgard de Andrade. Ele relatou que, num belo dia, estava trabalhando como editor de Cidades no Jornal da Tarde, quando recebeu o telefonema do amigo e respondeu perplexo: "mais você está louco, eu nunca trabalhei em televisão". O amigo respondeu que tudo tinha uma primeira vez e que ele também nunca tinha trabalhado em televisão antes e estava gostando da experiência. Mercadante aceitou o convite e a passagem para ir conhecer a tevê Globo do Rio de Janeiro e acabou ficando dez anos na emissora. Com relação à formação acadêmica, Mercadante revela que começou muito cedo no jornalismo, sem ter terminado o ensino médio:

${ }^{26}$ Entrevista gravada em São Paulo em 24 de outubro de 2006. 
Dia 24 de agosto de 54 o Getúlio se suicidou, eu nunca mais fui à escola. Depois, o mundo dá tantas voltas, né... dei até aula na escola universitária lá no Rio de Janeiro, me sentia o rei da cocada preta, mas bobagem (MERCADANTE, 2006).

O talento deste jornalista foi e é reconhecido até hoje como um dos textos mais brilhantes do jornalismo brasileiro, tendo trabalhado em veículos como $O$ Cruzeiro, Realidade ${ }^{27}$ e O Estado de S. Paulo. O convite para Mercadante trabalhar na televisão deveu-se aos seus textos, que na época eram publicados, diariamente no jornal. Somando a isso, ele também tinha trabalhado dois anos na rádio Eldorado de São Paulo. Contratado como chefe de redação da tevê Globo de São Paulo, Mercadante fez uma pequena revolução e começou a levar vários jornalistas de jornal e revista para a emissora:

Eu divido o telejornalismo de São Paulo em duas etapas bem distintas: antes e depois do Mercadante. A presença do Mercadante, sua liderança, sua capacidade de formar e motivar uma equipe foram fundamentais para a profissionalização definitiva do jornalismo, em São Paulo (MELLO E SOUZA, 1984: 272).

Não havia treinamento, nem curso de especialização, era só começar e ir aprendendo na prática, como foi o caso de Mercadante. Depois de algum tempo de trabalho na emissora, ele foi convidado a fazer um estágio na CNN e numa tevê Japonesa. Com relação a essas mudanças que ele, como jornalista, passou em veículos como rádio, televisão e jornal, Mercadante acrescenta: "eu sou do tempo que o jornalista era um profissional que trabalhava em televisão, que trabalhava em jornal, revista e rádio". As diferenças e peculiaridades entre cada veículo ele também avalia :

No jornal você entrega a matéria às sete da noite e sai às sete da manhã, no rádio você entrega as três pode sair as três e cinco, na televisão você entrega as três e pode sair às três e dois. O importante é a instantaneidade (MERCADANTE, 2006).

Uma de suas obras primas mais conhecidas foi a implantação do primeiro telejornal matutino na televisão brasileira, o Bom Dia São Paulo. Ele relata que foi chamado por Armando Nogueira e Alice Maria, então diretores de jornalismo

\footnotetext{
${ }^{27}$ Desta fase o destaque para as revistas $O$ Cruzeiro e Realidade como difusoras máximas da modalidade de perfil no Brasil, que no final dos anos 60 rarearam, e Luiz Fernando Mercadante foi considerado um dos ótimos textos junto com Carlos Azevedo, Roberto Freire e Oriana Fallaci. (VILAS BOAS, 2002: 96).
} 
da emissora, para implantar o Bom Dia em São Paulo, pois de acordo com Mercadante: "se a gente fizer o Bom Dia Rio, o doutor Roberto Marinho e os filhos dele vão ficar de olho, e o Bom Dia São Paulo só se passava em São Paulo, eu poderia cometer os erros que cometesse, sem ser julgado na hora". O primeiro telejornal matutino entrou no ar em 1977, como uma forma de prestação de serviço. Foi o primeiro a utilizar o equipamento de UPJ - unidade portátil de jornalismo, através de repórteres entrando ao vivo, de vários pontos da cidade. Depois, a experiência foi implantada em todas as emissoras afiliadas da Globo, com características regionalizadas.

Quando Mercadante chegou à televisão, era filme preto e branco, depois, veio o filme à cores e, passados alguns anos, as fitas Umatic e o VT: "é uma mudança bem grande, porque o filme chegava, tinha meia hora, quarenta minutos, uma hora, pra botar no ar. O VT se podia até passar da rua e ía pro ar o vídeo tape, né."

Fernando Pacheco Jordão ${ }^{28}$ também é da turma que não chegou a se diplomar, mas exerceu a função de jornalista desde sempre. Ele começou a fazer Ciências Sociais, mas devido à ditadura militar, que afastou e aposentou muitos professores, desistiu depois de um ano de curso. Antes de dedicar-se ao telejornalismo trabalhou, como redator do Estado de $S$. Paulo e nas revistas Veja e Isto É. Teve duas passagens pela tevê Cultura, uma de cinco e outra de quatro anos. Também trabalhou na extinta tevê Excelsior e na tevê Globo, no Globo Repórter. Exerceu as funções de produtor, diretor de jornalismo e diretor de programação. Na tevê Excelsior de São Paulo, de 1963 a 1964, criou o Show de Notícias, que foi um telejornal com a mesma linha inovadora do Jornal de Vanguarda e que, a exemplo do mesmo, também foi proibido de ser exibido.

Na tevê Cultura de São Paulo, Jordão, no final dos anos 60, organizou a primeira equipe de telejornalismo, baseado nas experiências que teve na Excelsior e, também, como observador que foi, em Londres, na BBC. Tendo trabalhado com o filme mudo, Jordão confessou que era muito trabalhoso fazer telejornal naquele momento, porque não tinham entrevistas gravadas: "eram só imagens ou, então, eu usava muito um recurso de trabalhar com gravador e som off no filme mudo". Mesmo tendo passado pela fase artesanal do

${ }^{28}$ Entrevista gravada em São Paulo em 31 de julho de 2006. 
telejornalismo brasileiro, Jordão acredita que a evolução tecnológica não facilitou as coisas para o jornalista. "Eu acho que continua sendo uma atividade difícil, né? A concepção da pauta e a realização, tudo isso é algo que exige um trabalho que, muitas vezes, não se vê na televisão". Outro destaque apontado por Jordão, para a informação televisiva, é a contextualização. "Tanto no documentário, quanto no telejornal diário, é preciso dar sempre o contexto da notícia, nunca deixar a notícia solta". Para ele, o telejornal, hoje em dia, é um grande mosaico, muito fragmentado, onde as pessoas ficam sem ter onde encaixar as notícias, as informações que recebem, diariamente, da televisão. Durante a sua passagem pelo Globo Repórter, ele relata que existia o documentário na emissora, que era o Globo Shell: "nessa época, ainda era muito influenciado pelo documentário de cinema". Mas Jordão inovou, propondo aos documentaristas que fizessem trabalhos diferentes, como é o caso do trabalho feito por Gregário Bacic, que foi exibido em 1977, o Retrato de Classe, onde não havia narração em off, e uma entrevistada conduzia à narrativa. Para ele o documentário é algo superior: "a parte mais rica da tevê é o documentário, mais do que a cobertura diária". Na próxima década, esse momento será mais bem detalhado.

A jornalista Clélia Cardim ${ }^{29}$, mais conhecida como Telé, também foi uma pioneira no telejornalismo, porque, ainda nos anos sessenta, conseguiu, mesmo sendo mulher, entrar no cenário do telejornalismo para trabalhar. Ela iniciou o curso de jornalismo na Cásper Líbero, mas depois mudou-de para o Rio de Janeiro e terminou a faculdade na PUC. Começou a carreira no impresso, no jornal Última Hora, com Samuel Wainer, e, depois, passou pela Excelsior, Tupi (até fechar), SBT e, atualmente, está na tevê Record. Cardim se orgulha de ter sido uma das primeiras mulheres a aparecer no vídeo como repórter: "não tinha mulher, era só homem. Eu saia pra produzir e resolvi fazer reportagem também". Ao longo da carreira, exerceu as funções de produtora, repórter, pauteira e chefe de reportagem. Mesmo tendo o diploma de jornalismo, naquela época, isso não era ainda uma exigência: "na época era aquela coisa, era o salve-se quem puder. Escrevia bem, era advogado, era importante, era não sei o que, lá chamavam pra escrever no jornal". Tendo

${ }^{29}$ Entrevista gravada em São Paulo em 26 de julho de 2006. 
acompanhado desde o final dos anos 50 todo o processo de evolução tecnológica da televisão, Cardim revela as dificuldades ocorridas no decorrer dos anos com a chegada das novidades: "sempre quando há uma coisa moderna sendo introduzida, sempre há uma repulsa, uma resistência". No começo, de acordo com ela, não havia uma boa definição das funções, todos eram uma espécie de faz tudo: "elas foram sendo ajeitadas, acomodadas de acordo com o passar do tempo; aí veio o próprio sindicato e a FENAJ, que foram muito importantes nessa transição".

Em março de 1967, o jornalista Gregório Bacic ${ }^{30}$ começou a trabalhar em televisão. Ele fez parte da primeira equipe de jornalismo da tevê Bandeirantes. O telejornal Titulares da Notícia só entrou no ar em 13 de maio daquele ano. A experiência que Bacic tinha anteriormente era no rádio. $A$ exigência básica feita aos jornalistas que foram trabalhar na televisão, naquele tempo, era o texto: "então era um texto fluente, bom, um texto compreensível, um texto enxuto". Na televisão, Bacic exerceu as funções de redator, editor, repórter e diretor de jornalismo. Trabalhou na Bandeirantes (Titulares da Notícia), na Globo (Jornal da Globo e Globo Repórter) e na Cultura (Hora da Notícia). Atualmente é diretor do programa Provocações, da tevê Cultura. Em 1979, foi diretor de jornalismo da rádio Nacional, no Rio de Janeiro. Nesta época, revelou Bacic, tudo girava em torno da figura do redator, que hoje em dia passou a ser o editor de texto: "existia ainda uma concepção, um desenho muito fundamentado no redator". Ele também ressalta o empobrecimento que houve daquele tempo para os dias atuais:

Houve, de lá pra cá, acho que um empobrecimento, vamos assim dizer, da necessidade de redatores, porque as coisas já vêm prontas. Nós estamos, assim, numa espécie de fast food jornalístico, em que as assessorias de imprensa, agências noticiosas, esses serviços todos, já mandam textos que, muitas vezes, são colocados no ar (BACIC, 2005).

Para completar esta seção, e como parte da proposta deste trabalho, apresentaremos algumas comparações relativas à trajetória de formação do telejornalista brasileiro nas décadas de 50 e de 60 .

Nos anos 50, com a chegada da televisão no Brasil, o que houve, por parte dos profissionais que foram convocados do rádio para a televisão, foi uma apropriação das técnicas utilizadas no rádio. Os profissionais não

\footnotetext{
${ }^{30}$ Entrevista gravada em São Paulo em 21 de setembro de 2005.
} 
dispunham de bibliografia específica de televisão, porque não existia este veículo no país. O que ocorreu foi uma adequação das rotinas que eles estavam acostumados a desempenhar no rádio para a televisão, sem levar em conta que, na televisão, o grande diferencial era a imagem. Talvez, por isso, tenha surgido o termo "rádio com imagens" para designar a novidade. Nos anos 60, houve a valorização da figura do redator, pois começou-se a pensar num texto mais adequado para o veículo e diferente do utilizado pelo rádio, pois era preciso valorizar as imagens. Alguns profissionais do impresso, no final da década, começaram a ser convocados para trabalhar na televisão, devido ao texto que haviam desenvolvido.

As condições relatadas pelos profissionais, nos anos 50 , eram precárias, pois a imagem era produzida em filme preto e branco e mudo, o que dificultava, e muito, o trabalho do telejornalista. A qualidade do trabalho também não era boa, devido às imagens escuras e à falta de factualidade das notícias, que eram baseadas nos jornais do dia, só que eram exibidas à noite. Não era possível a realização de entrevista, devido à falta de som. O que se fazia era uma narração para o locutor ler, enquanto eram exibidas as imagens. Já nos anos 60, com a chegada do vídeotape, as condições técnicas de trabalho começaram a melhorar e começaram-se a fazer a gravação de entrevistas em casos de depoimentos de pessoas importantes.

Não havia nenhum tipo de treinamento, nem formação específica para 0 telejornalista nas décadas de 50 e 60. Era necessário aprender na prática, também havia preconceito com relação aos profissionais da televisão, pois esta ainda era considerada um veículo sem conteúdo.

Enquanto a década de 50 foi marcada pela improvisação e irregularidade dos horários dos programas, além de uma tecnologia rudimentar, sujeita a muitas falhas, nos anos 60, alguns telejornais começaram a ter seu horário fixo e buscavam uma identidade própria, como foram os casos do Jornal de Vanguarda, no Rio de Janeiro e do Show de Notícias, em São Paulo. Mas, com o golpe militar em 1964 e a imposição de uma ditadura, o desenvolvimento dos conteúdos nos telejornais foi prejudicado, devido à censura, que impedia a veiculação de informações que não fossem do interesse do regime. A televisão foi considerada por muitos autores, neste período, como o veículo mais censurado durante a ditadura. 
Havia também, nos anos 50, uma falta de definição das funções dentro das emissoras, os profissionais eram uma espécie de faz tudo. Na década seguinte, esse quadro começou a mudar, com a implantação de algumas funções básicas, como a do redator ${ }^{31}$, que hoje em dia é conhecido como editor de texto.

$\mathrm{Na}$ próxima seção, trataremos da participação dos cineastas no processo de formação do telejornalista brasileiro e, ainda, da implantação do modelo americano, a partir da criação do Jornal Nacional, que ocorreu no final da década de 60.

\subsection{Segunda Fase - Cinematográfica e Modelo Americano - décadas de 1970 e 1980}

"Nós passamos a ver o mundo em positivo e a cores, tal como ele é".

MELLO E SOUZA

A década de 70 foi um momento, onde alguns fatos marcaram a vida do telejornalista brasileiro. Entre eles, destacam-se a evolução tecnológica, a cópia do modelo americano e a ditadura militar.

Tecnologicamente, foi o momento da utilização rudimentar do "cromaqui"32. Digo rudimentar, porque, às vezes, o azul do "croma" passava para os cabelos grisalhos do Cid Moreira e os técnicos tinham que se virar para não o deixar entrar no ar daquele jeito. O problema só foi resolvido depois que a empresa Colortram orientou os iluminadores na utilização do contraluz, da luz chave e da luz de base, para minimizar os efeitos incorretos. Outra medida adotada foi à mudança do tom de azul do "cromaqui" (MELLO E SOUZA, 1984: 124).

Outra nova tecnologia incorporada em 1974 foi o teleprompter ${ }^{33}$. Na tevê Globo, ele foi introduzido em 1974. Os primeiros modelos eram de mecânica

\footnotetext{
${ }^{31}$ A função de redator veio para a televisão junto com alguns profissionais que vieram do impresso.

${ }^{32}$ Aquele cenário azul que fica por trás dos locutores, onde o diretor pode jogar qualquer outra imagem.

${ }^{33}$ Equipamento que faz com que o texto a ser lido pelo apresentador passe na frente, ou em cima e ao lado como as primeiras versões, da câmara evitando que o mesmo tenha que ler na lauda e olhar para a câmera num movimento anti-didático e visualmente feio.
} 
simples, com um jogo de espelhos. O texto a ser lido aparecia um pouco acima da câmara, em letras grandes, o que proporcionava ao apresentador, um olhar altivo, de superioridade, sem conseguir olhar o telespectador nos olhos, ainda. De acordo com Mello e Souza, a partir do teleprompter, o locutor não ficou mais obrigado a fazer aquele incômodo movimento de baixar e levantar a cabeça, de olhar para a câmara e voltar ao texto do script, lendo com mais naturalidade, sem ter que se preocupar em olhar no script e olhar para a câmera. Depois, o equipamento foi evoluindo, e nos dias de hoje, o teleprompter está integrado ao sistema de informática existente na maior parte das emissoras e não proporciona mais ao apresentador o olhar de superioridade.
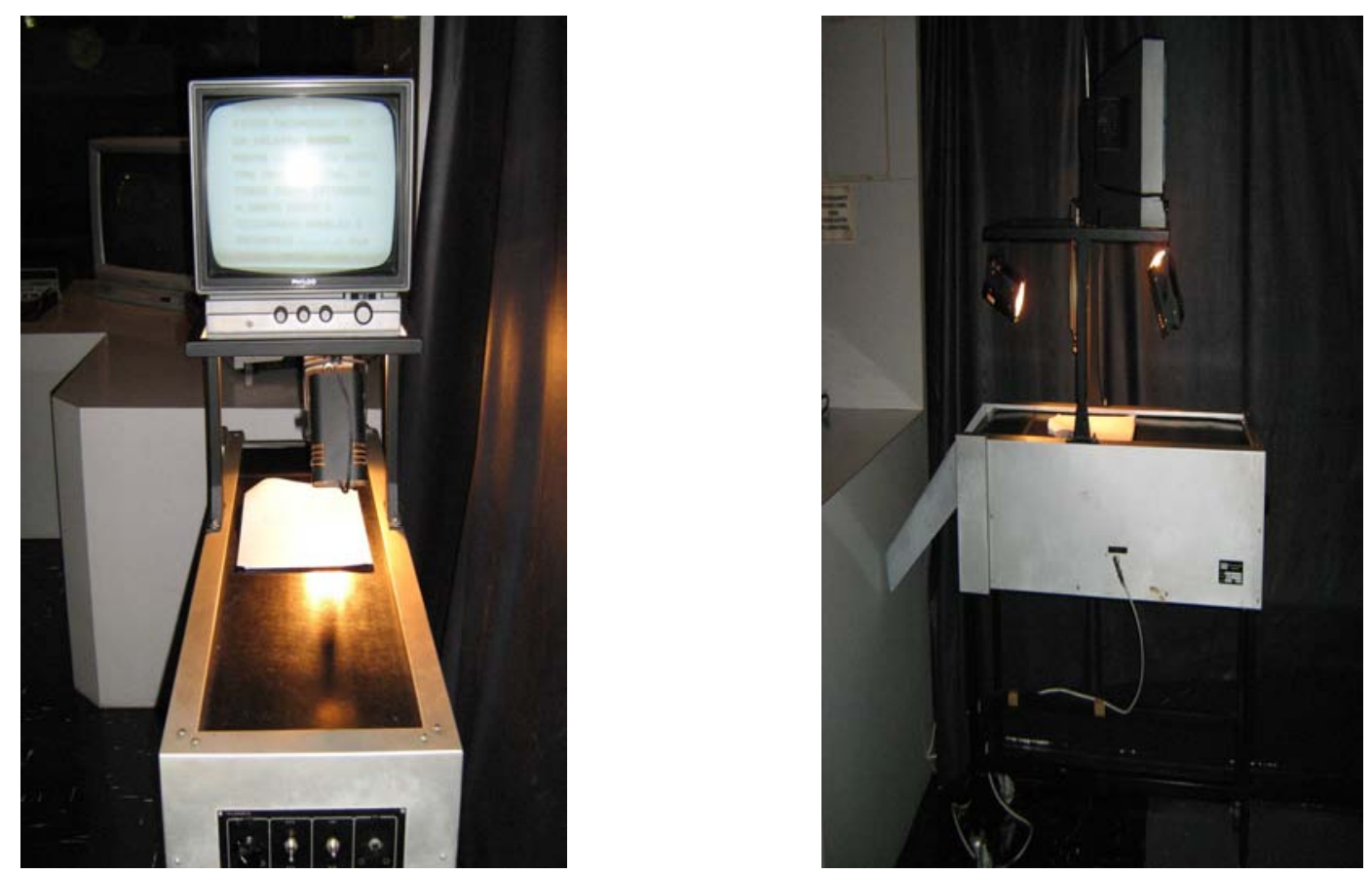

Um dos primeiros modelos de teleprompter ainda está em funcionamento na Eca/Usp

Nesta década de 70, surgiu o filme colorido e, aí, se trabalhava com a câmera CP Micthell. As redações, primeiramente a da tevê Globo, buscavam minimizar os erros da operação do telejornal diário, aprimorar e padronizar os procedimentos dos telejornalistas, mas já com os primeiros indícios da influência americana no modo de fazer telejornal.

Havia algumas normas básicas de redação. Em 1975, por exemplo, essas normas achavam-se já compendiadas em um pequeno manual, baseado em uma publicação americana e adaptada à fala brasileira, com todas as suas peculiaridades e exigências. Estavam prescritos, 
desde então, alguns cuidados básicos, tais como: evitar palavras longas, formular frases curtas e começar o texto com gerúndio (MELLO E SOUZA; 1984: 153).

Nessa época, ainda era muito comum os radialistas migrarem para televisão, devido à sua experiência em rádio, como foi o caso do jornalista Laurindo Leal Filho ${ }^{34}$, que após ter trabalhado dez anos (de 62 até 72) na Fundação Vitor Costa, fazendo tudo na área de rádio. Como repórter, depois, como comentarista, como locutor, fui um dos primeiros a transmitir Fórmula Um, passou a trabalhar na TV Cultura de São Paulo, como repórter. Depois de um ano, ele passou a ser editor internacional:

Como repórter, eu pude acompanhar todo o processo de edição. Aliás, havia um cuidado lá, a gente na TV Cultura acompanhava quase todo o processo, o repórter acompanhava junto com o editor. Eu fui me habilitando, na prática, até me tornar editor do telejornal da Cultura (LEAL FILHO, 2007).

O filme preto e branco ainda era utilizado em algumas emissoras de televisão. No caso da tevê Cultura, as equipes utilizavam uma CP - um equipamento enorme, para realizar a filmagem e, depois, tinham que voltar para a emissora, revelar esse filme e editar numa moviola, como as de cinema (tecnologicamente, a tevê Cultura estava um pouco atrasada em relação às outras emissoras). Segundo Leal Filho, naquela época, punha-se uma ponta branca, pra ligar as duas partes do filme, como uma espécie de fita crepe; "era o momento em que você terminava o filme e voltava pro estúdio e, aí, o locutor chamava e aquela ponta branca continuava correndo até a matéria seguinte". De sua passagem pela tevê Cultura, Leal Filho guarda um momento triste da época da ditadura e da convivência que teve com o jornalista Vladimir Herzog, mais chamado, carinhosamente pelos colegas, de Vlado:

Havia vários jornalistas presos, havia um clima ruim e o Vlado numa sexta-feira de outubro, também tinha dois empregos. Ele tava lá na Cultura e trabalhava na revista Visão, que funcionava na Afonso Celso, na Vila Mariana, e não guiava. Ele me viu saindo, nós terminamos o jornal. Ele me pediu uma carona até a Visão, e como eu morava em Moema, era caminho, né? $\mathrm{E}$ aí fomos conversando e ele meio preocupado com aquela crise toda, com aqueles companheiros presos. Deixei-o lá e me despedi, até segunda. Aí ele nunca mais voltou (LEAL FILHO, 2007).

\footnotetext{
${ }^{34}$ Entrevista gravada em São Paulo em 30 de maio de 2007.
} 
Depois, nos anos 70, Leal Filho foi lecionar telejornalismo, primeiro na PUC de São Paulo, depois na Escola de Comunicações e Artes da USP. As suas aulas eram uma reprodução da experiência prática que ele tinha vivenciado nas redações onde trabalhou: "eu, na verdade, não trabalhava muito com teorias nessas áreas, eu dava cursos iminentemente práticos". Com o tempo, começou a agregar alguns livros na bibliografia, como o Manual de Telejornalismo, lançado por Vera Íris Paternostro. Mas o ponto alto de suas aulas, nas discussões com os alunos, foi o debate crítico dos modelos institucionais de televisão. De sua passagem pela academia, uma história marcou o seu trabalho, no curso de documentário, onde os alunos eram estimulados a produzir pequenos trabalhos, ao final do semestre. O problema era que estes trabalhos não tinham divulgação pública, eles simplesmente recebiam nota e eram arquivados na videoteca da ECA. Mas, um grupo que realizou um trabalho sobre esquizofrenia, conseguiu exibir o trabalho no Doc TV, da tevê Cultura (concurso de documentários), e inscrever o vídeo no prêmio Vladimir Herzog de direitos humanos, que é organizado pelo Sindicato dos Jornalistas de São Paulo. E ganharam o primeiro lugar, na categoria telejornalismo: "é uma história que dá muito prazer, o troféu Vladimir Herzog está lá na vitrine do departamento de Editoração e Jornalismo da Eca". Atualmente, Leal Filho está aposentado da função de professor da Escola de Comunicações e Artes da USP, mas atua na pós-graduação da Fundação Cásper Líbero e apresenta o programa Ver TV na tevê NBC, onde ele exercita o que mais gosta de fazer - 0 debate e crítica da televisão brasileira. Recentemente, em agosto de 2008, foi nomeado ouvidor-geral da EBC - Empresa Brasil de Comunicação. Ao longo de sua carreira acadêmica, Leal Filho cursou o mestrado e doutorado. Relatou sua experiência na tevê Cultura no livro: Atrás das Câmeras - relações entre cultura, estado e televisão. Na seqüência, realizou uma pesquisa de pósdoutorado, na Inglaterra, sobre a BBC. Da pesquisa, foi publicado o livro: $A$ melhor TV do mundo - o modelo britânico de televisão. 

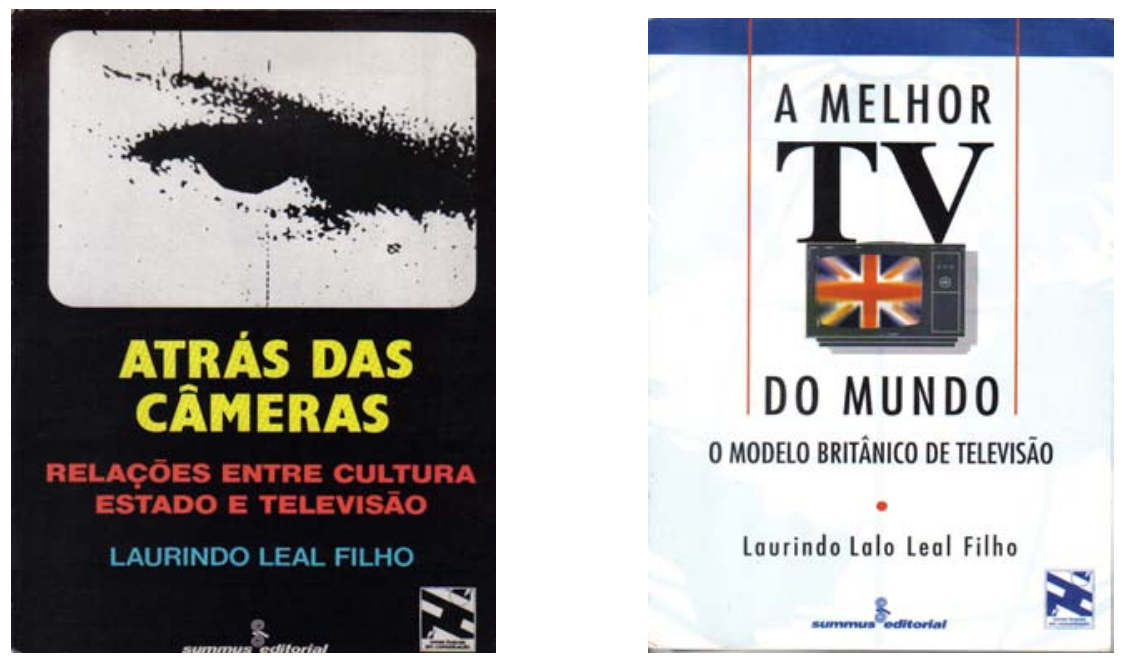

As publicações de Laurindo Leal Filho.

O jornalista e professor Sebastião Carlos de M. Squirra ${ }^{35}$ começou a lecionar em jornalismo, em 1979. Ele é formado em jornalismo e possui mestrado e doutorado, enfocando o telejornalismo. Passou por instituições como PUC, FAAP, FIAM, ECA e Metodista. De acordo com ele, no início, a disciplina chamava-se videojornalismo e, depois, passou para telejornalismo. Em algumas instituições de ensino, como a Unesp de Bauru, por exemplo, o nome adotado para a disciplina é Jornalismo Televisado. Sua experiência anterior era em cinema, pois tinha trabalhado na Blimp Filmes, com documentários e um pouco de publicidade. Nas aulas, sempre imprimiu um ritmo muito prático, com a realização de telejornais em circuitos internos, dentro das próprias instituições:

\footnotetext{
Os alunos precisavam aprender a produzir telejornal contra o tempo. Não é produzir um telejornal para ir ao ar na semana que vem. Primeiro a factualidade; o fato, com o tempo, estará desatualizado, mas o desafio para o jornalista de televisão, pro aluno, que poderá um dia querer um cargo, é trabalhar sobre pressão (SQUIRRA, 2007).
}

Mas não deixou de fora uma parte teórica do telejornal. Usava um dos primeiros manuais da Globo, o livro do Walter Sampaio, que foi o pioneiro nesta disciplina e, ainda, produzia e imprimia uma apostila para que os alunos pudessem acompanhar os conteúdos. Na apostila intitulada $A$ Técnica do Telejornalismo, Squira aborda a imagem, a câmara eletrônica, as configurações de equipamento, a linguagem televisual, a iluminação básica em

\footnotetext{
${ }^{35}$ Entrevista gravada em São Bernardo do Campo em 31 de maio de 2007.
} 
telejornalismo, a sonoplastia e a captação sonora. Na publicação, existe, também, um glossário de termos técnicos relativos ao telejornalismo e um conjunto de anexos, exemplificando o espelho do telejornal, a lauda, o relatório de reportagem e a pauta de emissoras, como tevê Globo, Manchete e Bandeirantes. O conteúdo, apesar de técnico, é explicado de forma didática e conta com a presença de ilustrações que ajudam o entendimento. Nos anos 80 , na pós-graduação, conseguiu compilar toda a experiência de aulas de telejornalismo e a pesquisa, o que Ihe rendeu a publicação de sua dissertação de mestrado: Aprender telejornalismo - produção e técnica, onde ele afirma ter dado uma pequena contribuição. Na realidade, este trabalho foi uma grande contribuição ao ensino e a pesquisa em telejornalismo, devido à fundamentação teórica e à experiência prática apresentadas, e não uma simples reprodução de antigos manuais. O livro foi publicado em 1989, em 1993, e reimpresso em 2004 e 2006. Depois, no doutorado, a tese de Squirra deu origem a outro clássico do telejornalismo: Boris Casoy - o âncora no telejornalismo brasileiro. Em paralelo às aulas trabalhou nas tevês Bandeirantes e Cultura, como repórter, produtor-executivo e editor. Só passou a se dedicar integralmente à academia a partir de 1985.
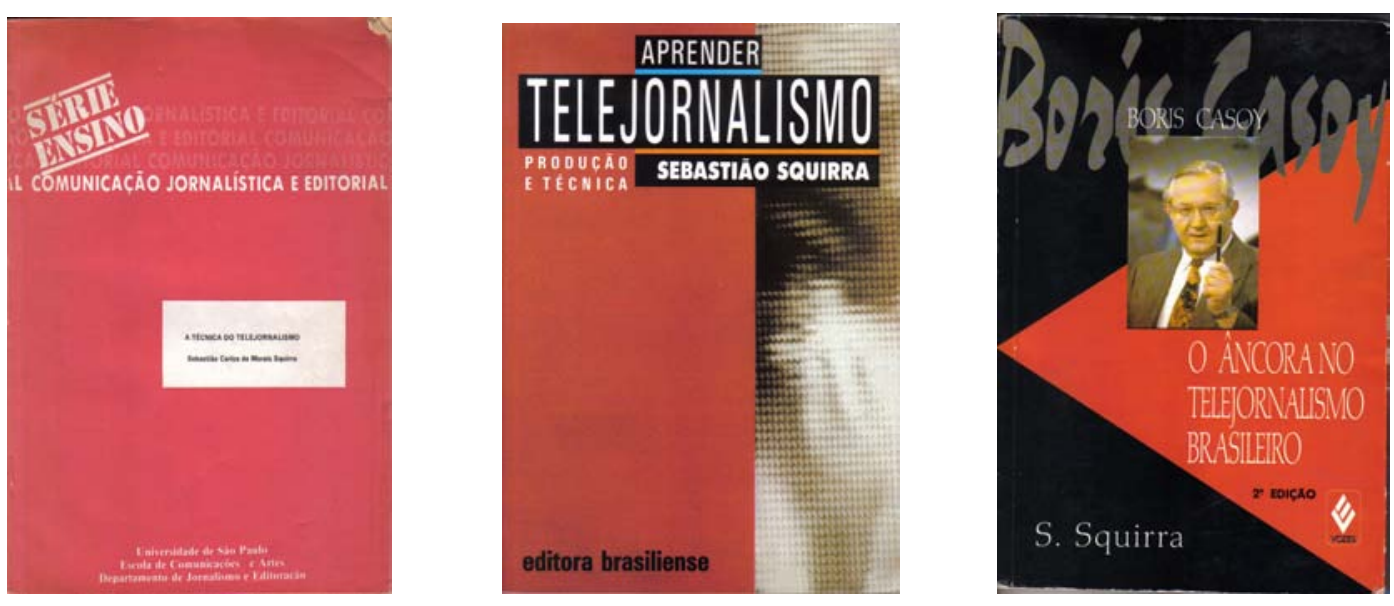

As três obras de Squirra: a apostila de aula, a dissertação de mestrado e a tese de doutorado.

A década de 70 foi marcada por algumas produções calcadas no telejornalismo, como o Globo Repórter, que contou com a contribuição de cineastas e jornalistas como Gregório Bacic e Fernando Pacheco Jordão, entre outros. 
Durante sua passagem pelo Globo Repórter, Gregório Bacic fez parte de uma equipe de cineastas, com João Batista de Andrade, Eduardo Coutinho, Hermano Pena, entre outros. Essa equipe, comandada em São Paulo por Fernando Pacheco Jordão, introduziu o documentário cinematográfico na televisão brasileira. Os documentários eram verdadeiras obras de arte, pois inovavam na linguagem, na montagem e na narrativa. Desta época, Bacic destaca o documentário Retrato de Classe, que foi um trabalho onde ele partiu de uma foto escolar dos anos 50 para encontrar todos aqueles ex-alunos, 20 anos depois, e mostrar, através da narrativa central da professora sobre seus alunos, o rumo que cada um tomou na vida. O documentário chegou a ser noticiado pelos jornais e pela revista Veja da época, devido ao seu realismo e à crítica que fazia à classe média paulistana. Isso gerou comentários da direção da emissora, alegando que esse tipo de realidade não deveria ser exibida na televisa, culminando com a exclusão de Gregório Bacic do time de colaboradores do Globo Repórter. Mas o trabalho Ihe rendeu tanto destaque e mérito profissional, que, até nos dias de hoje, ele é convidado para exibir e debater o conteúdo e a forma do documentário, em universidades do Brasil e do exterior.

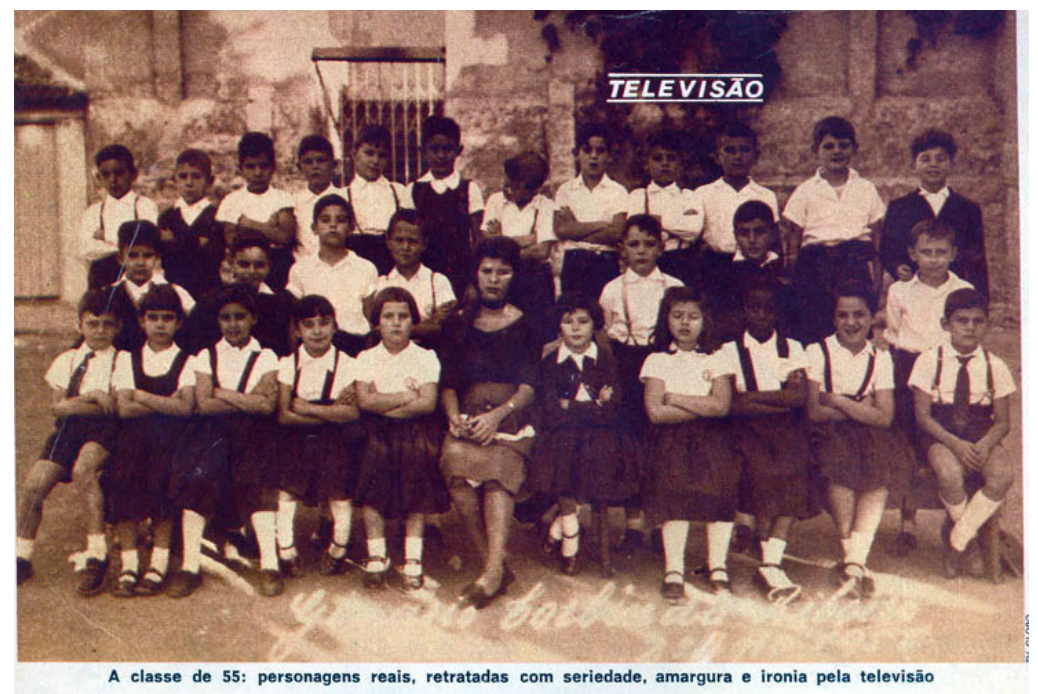

O cineasta João Batista de Andrade ${ }^{36}$ é doutor em comunicações, mas não terminou a graduação em engenharia, que foi interrompida em 1964, no

${ }^{36}$ Entrevista gravada em São Paulo em 12 de dezembro de 2006. 
quinto ano, por causa do golpe militar. Como professor de direção de cinema, desde 1968, nos anos 90 foi convidado a fazer o doutorado direto, para compensar todo o trabalho e a contribuição que deu na formação dos alunos da Escola de Comunicações e Artes da USP. A tese O povo fala é um relato sobre a participação de um cineasta na área de jornalismo da tevê brasileira, onde ele apresenta a presença da televisão na vida brasileira que, "particularmente a partir do final dos anos 60 , mudou profundamente a relação dos meios de comunicação com a sociedade, no tocante à informação". (ANDRADE, 2002: 15). Uma qualificação feita por Andrade é a respeito do tratamento feito ao noticiário no país, nos anos da ditadura: "poupando o público e enfeitando notícias capazes de chocar" (ANDRADE, 2002: 16). Ele também compara o noticiário televisivo com os outros veículos de comunicação: "faz de conta, mas sem agressividade dos noticiários do rádio e jornais" (ANDRADE, 2002: 16). Para o telejornal em si, Andrade analisa os fatores estéticos que contribuem para a espetacularização da notícia:

\begin{abstract}
Entram agora, como fatores importantes de composição dos noticiários, não somente a voz, mas a aparência dos apresentadores e sua capacidade de cativar o público, de gerar confiança. E, também, o formato audiovisual do programa, a direção de arte, o logotipo, os painéis, as vinhetas, a ornamentação do estúdio, como um espetáculo de notícias adequadas ao público que se pretende atingir (ANDRADE, 2002: 17).
\end{abstract}

Uma outra crítica que Andrade faz questão de fazer é com relação à personalidade do repórter de televisão, desde o início: "é o caso, por exemplo, do repórter Tico-Tico, que parece ter inaugurado, na tevê brasileira, o estilo 'olha eu aqui ao lado do Papai', que, ainda hoje, marca a qualidade das reportagens, calcadas no ego inflado dos repórteres de vídeo" (ANDRADE, 2002: 19). A participação de Andrade no telejornalismo dos anos 70 deu-se através do Globo Repórter. Mesmo com o grande preconceito que havia da área de cinema em relação à televisão, ele participou desta fase e também na tevê Cultura. O preconceito dos cineastas com a televisão se deveu a falta de informação, pois, quando a televisão foi implantada no Brasil, houve a impressão, por parte deles, que o cinema iria acabar. Também tinha a contrapartida que a televisão se instalou no Brasil sem o cinema, ao contrário do que aconteceu, por exemplo, nos Estados Unidos. A tevê americana não podia competir com o cinema, então, ela tinha, por lei, que comprar a produção 
do cinema e produzir apenas programas específicos. Na fase dos cineastas no Globo Repórter, recém saído da tevê Cultura, onde junto com o jornalista Vladimir Herzog fazia o Hora da Notícia, Andrade foi contratado, em 1974, para criar o setor de reportagens especiais. "Eu sou o único cineasta do mundo, que fazia um documentário por dia, que entrava no jornalismo diário, que era 0 Hora da Notícia, na tevê Cultura, às 9 da noite." A transferência da Cultura para a Globo foi uma espécie de queda para o alto, pois depois de muita perseguição, expulsão e demissão na primeira, ele saiu de uma emissora pequena para a maior audiência do país. Mas Andrade trabalhava com uma temática muito crítica, muito social, o que o levou a ter vários problemas, como a proibição, em 1978, pelos militares, do documentário Wilsinho Galileia - que era sobre um garoto que transformou-se em bandido e foi fuzilado pela polícia, aos 18 anos. Essa acabou sendo uma espécie de gota d'água para que a tevê Globo tirasse o programa dos cineastas e passasse aos repórteres. O filme só foi exibido 24 anos depois, no ano de 2002, no Festival Internacional de Documentário - É tudo Verdade. Outro feito de Andrade, nesta fase, foi uma experiência, onde ele misturava ficção e documentário, no Caso Morte. A iniciativa fez muito sucesso e o levou a ganhar o prêmio de melhor programa do ano. Quando os cineastas foram retirados do Globo Repórter, em 1979, entraram os repórteres, que eram,, segundo Andrade, mais dóceis e faziam parte de uma estrutura jornalística. "Na nossa época, o assunto era o Brasil. Quando mudou, o assunto era o repórter. Quero dizer, o público assiste o repórter igual a um grupo de turistas que assiste o guia. Quanto mais espirituoso o guia, mais o turista gosta". Sobre esta passagem dos cineastas pela tevê Globo, vale ressaltar o trabalho desenvolvido pelo jornalista Igor Sacramento, em sua dissertação de mestrado, pela ECO, da UFRJ, intitulada Depois da revolução, a televisão - cineastas de esquerda no jornalismo televisivo dos anos 70, em 2008, onde o autor analisou o que criou as condições para a presença e para a participação de cineastas, identificados com o Cinema Novo, em programas jornalísticos da tevê Globo, nos anos 70. De acordo com Sacramento, a entrada e a atuação de artistas de esquerda na televisão "correspondeu a um processo de esfacelamento dos projetos coletivos de transformação social e à pulverização de condutas individuais centradas na carreira e no sucesso, objetivos extremamente articulados à 
"atomização reitificada" da vida social (JAMESON, 1995:24). A utopia, como um programa político radical e coletivo, teria deixado de existir, mas ainda continuaram a haver resquícios, não importando se de forma plenamente consciente ou não. Foi-se a utopia revolucionária, mas não se foi a utopia." (SACRAMENTO, 2008: 63). De acordo com ele, o Globo Repórter entrou no ar em 03 de abril de 1973 e foi o único programa da emissora a usar equipamento cinematográfico. O programa tinha como objetivo oferecer os acontecimentos, assim como o adensamento das discussões, através do desenvolvimento de temáticas sociais, como a miséria, a desigualdade social e a luta pela terra, que eram ignorados ou poucos retratados por outros programas jornalísticos (SACRAMENTO, 2008: 107-108).

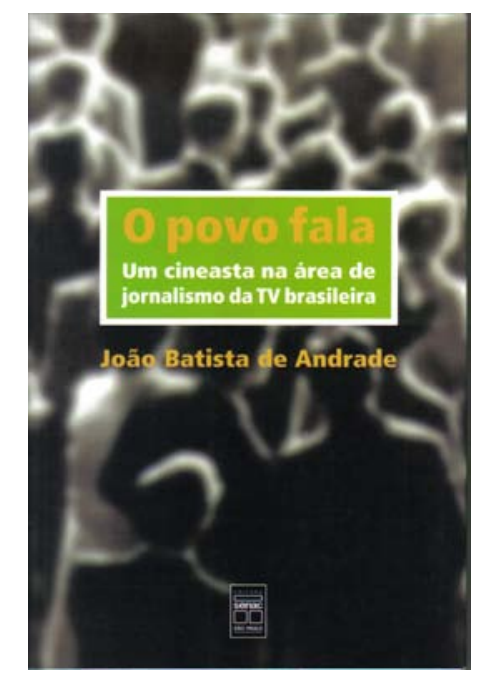

A tese de doutorado de João Batista de Andrade

O documentarista e cineasta Eduardo Coutinho ${ }^{37}$ trabalhou durante 9 anos, na produção do Globo Repórter, no Rio de Janeiro. Apesar de não ter cursado jornalismo, Coutinho tinha experiência de três anos, na revista Visão, e de 5 anos, no Jornal do Brasil. Ele também cursou direito (mas não se diplomou) e cinema, na França. Em 1975, foi convidado para trabalhar no Globo Repórter, pelo seu chefe no jornal, Nilson Alves, e, depois de duas

\footnotetext{
${ }^{37}$ Entrevista gravada no Rio de Janeiro em 16 de junho de 2008.
} 
tentativas, aceitou, porque era para trabalhar com documentário "e o Globo Repórter tinha mais a ver com cinema, era feito em cinema." A função ocupada por Coutinho, segundo ele, era "pau pra toda obra", pois ele "na verdade, filmava, traduzia, editava." Apesar de sua formação em cinema, ele nunca havia trabalhado com documentário, só havia feito ficção. "Eu fui fazer documentário na televisão (...) eu fui pra lá e comecei a fazer uma coisa que às vezes era reportagem, às vezes era meio documentário". Coutinho reconhece aquela fase como um grande aprendizado e um momento maravilhoso, no início. "Em 9 anos, os primeiros 4 foram bons, depois passou a ser desinteressante." Entre os trabalhos que fez durante esse período, Coutinho destaca dois: o primeiro, Seis Dias de Uricouri, primeiro documentário exibido pelo Globo Repórter durante um programa inteiro; até então, os programas tinhas dois ou três temas; esse privilégio era concedido apenas para os filmes estrangeiros, mas, a partir daí, virou uma regra para os nacionais também; e o segundo, Teodorico, o Imperador do Sertão, o qual ele considera o melhor filme que já fez para o Globo Repórter, "sobre um coronel, que possuía escravos, dono de almas." Apesar de ter trabalhado no Globo Repórter, no período da ditadura, Coutinho faz questão de deixar claro que, apesar da censura, dos prazos e do plano de uma indústria, havia a liberdade que deixou de existir há 20 anos. "Do ponto de vista formal, tinha mais liberdade, todos tinham mais liberdade do que hoje." Ao mesmo tempo, ele recorda um momento de extrema importância, quando a censura foi liberada, em 78-79, e o problema passou a ser a censura interna que havia se arraigado dentro da redação da Globo. Neste período, foi feito um programa sobre a morte de Getúlio, onde entrou um trecho enorme da carta testamento; depois, em 1982, um outro programa pretendia usar o mesmo texto, porém, foi impedido, pessoalmente, pelo jornalista Roberto Marinho. Isso aconteceu às 7 da noite e como o programa ía ao ar às 9, não havia tempo de mexer na montagem, "daí, ficou, sei lá, três minutos com o Réquiem de Mozart e ficou três minutos sem texto, tempo danado em televisão, mas eu não troquei uma palavra e não tirei uma imagem: isso é o que é mais engraçado." 
A década de 70 também marcou também o surgimento dos primeiros correspondentes internacionais brasileiros. A repórter Sandra Passarinho ${ }^{38}$ foi enviada a Portugal para cobrir a Revolução dos Cravos. Ela recorda que aprendeu fazendo: "meu aprendizado foi enorme, a duríssimas penas, porque a gente dormia pouco, aquelas coisas. Imagina Portugal, no auge do golpe. Você tinha informações contraditórias vindo de todos os lados". Passarinho foi a primeira repórter mulher da tevê Globo e também a primeira correspondente internacional. Ela relata que, ao ser convidada para trabalhar na emissora, não possuía formação em jornalismo e que, aos poucos, foi sendo treinada no diaa-dia da redação. Depois desta cobertura internacional realizada por Passarinho, a emissora apressou a decisão de instalar os primeiros escritórios da Rede Globo no exterior. O primeiro escritório instalado foi em Londres, com Sandra Passarinho, e logo depois, em Nova lorque, com Hélio Costa. De acordo com Mello e Souza, isso ocorreu devido às pressões exercidas pela ditadura ao noticiário nacional, que era de má qualidade, e que levaram Armando Nogueira a mudar o foco e investir na cobertura internacional. Ou seja, já que não se tem liberdade para cobrir com qualidade os assuntos do Brasil, era necessário fazer um trabalho digno com o noticiário internacional. 0 telejornalismo, nesta época, era tão censurado quanto os jornais impressos, relatou Passarinho. "Existia uma pessoa na redação, um jornalista que era o contato com os militares, e os militares mandavam os comunicados. Os mesmos comunicados que íam para a imprensa escrita, vinham pra redação." Aos poucos, os jornalistas criavam formas de sinalizar para o telespectador que alguma coisa estava errada no noticiário. Como foi o caso, que Passarinho recordou: "às vezes, quando tinha uma notícia que não podia entrar, no lugar de uma notícia nacional que a gente tinha, que teria que ser colocada no ar, a gente dizia o preço do cobre, do ouro." Outras vezes, mesmo sem ser proposital, devido à correria do fechamento do telejornal, algumas associações eram feitas espontaneamente, como foi o caso relatado por Passarinho, num final de ano do período da ditadura:

Houve um banquete do Médice, no final de ano. Era a preparação da festa, no Palácio do Planalto, da família presencial e tal. Foi dada essa informação Imediatamente, depois disso, entrou uma notícia sobre um

${ }^{38}$ Entrevista gravada no Rio de Janeiro em 20 de novembro de 2006. 
banquete de mendigos aqui no Rio. Foi um choque e, ao mesmo tempo, muito revelador do que nós vivíamos (PASSARINHO, 2006).

A jornalista Vanessa Kalii ${ }^{39}$ começou a trabalhar em telejornalismo, em 1978. Filha do falecido Repórter Esso, Kalil Filho, teve como impulso à profissão a lembrança dos tempos áureos do pai. Sua primeira experiência em televisão foi na tevê Globo, como estagiária de reportagem, no programa Globinho, que foi considerado o primeiro telejornal infanto-juvenil da televisão brasileira. Kalil foi repórter, apresentadora e editora do programa. No início da carreira como repórter, ela ressalta que a linha era bem mais dura do que hoje em dia: "você tinha que chegar da rua com o seu texto pronto e gravado. Era proibido, na Globo, você gravar texto na redação". Mas a experiência do Globinho durou até 1981, depois disso a emissora resolveu investir em outro tipo de programa para esse público. Com o final do Globinho, Kalil passou, definitivamente, para o departamento de jornalismo, tendo trabalhado no Jornal Hoje, São Paulo Já, SPTV, entre outros. Atualmente, é editora, na tevê Bandeirantes de São Paulo. No período em que foi editora executiva do Bom Dia São Paulo, mesmo tendo que entrar às 4 horas da manhã, Kalil recorda que fazer a condução de um jornal foi uma fase muito gratificante de sua carreira, com episódios marcantes:

A gente tava saindo do ar, caiu o avião da Tam ali perto de Congonhas. O Bom Dia tinha um helicóptero para mostrar transito e tal. Eu acabei nem saindo do switcher, que é o lugar que você põe o jornal no ar. A gente começou a mostrar as primeiras imagens, sem saber o que tinha acontecido. Aí eu trabalhei o dia inteiro, sem sair do switcher, nem pra comer, nem pra nada. E assim é um trabalho que não é intelectual, mas é uma coisa muito emocional também (KALIL, 2006).

Algumas das dificuldades do início da carreira e que hoje já estão superadas para Kalil são a lauda datilografada e a falta de câmeras mais compactas. "Antigamente, você batia uma lauda e se cometia algum erro de digitação, tinha que riscar ou escrever tudo de novo. O que a gente tem hoje de novo é a câmera escondida, você tem ela muito menor, muito mais fácil". Para ela, outra mudança dos dias atuais, é que o repórter tem pouca autonomia, pois o editor é o pai da matéria: "ele liga para o repórter, ele discute com o repórter. $\mathrm{Na}$ verdade, hoje a gente é mais babá de repórter do que qualquer outra coisa."

${ }^{39}$ Entrevista gravada em São Paulo em 14 de novembro de 2006. 
Todas essas inovações e facilidades, de que o telejornalismo dispõe hoje em dia, para Kalil, deixou-o mais pobre:

Você tinha que apurar com mais dificuldade. Hoje não, você tem tudo na internet. Mais é muito mais pobre, em termos pessoais. As pessoas já não são pessoas top de linha. Eu sinto muito, eu acho que, do mesmo jeito que a humanidade está mais pobre hoje, eu sinto isso no jornalismo, infelizmente (KALIL, 2006).

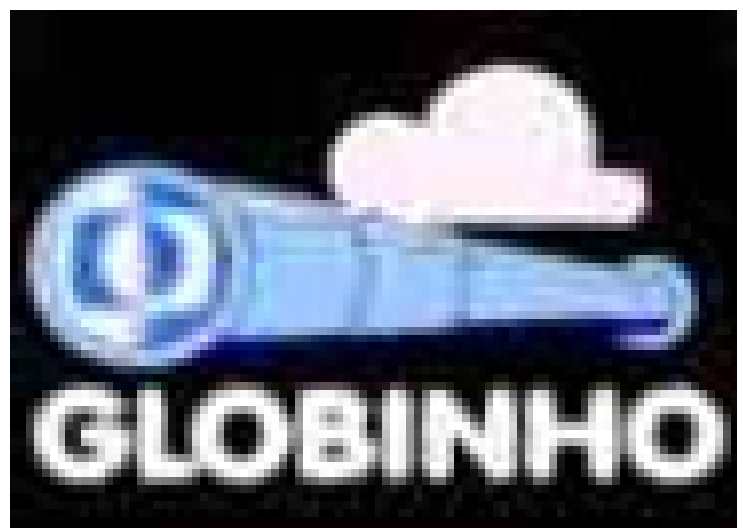

O logotipo do primeiro telejornal infanto-juvenil Globinho

Nos anos 80 , houve uma mudança tecnológica grande na estrutura operacional das emissoras de televisão e, conseqüentemente, também, para o telejornalista. As emissoras saíram da produção em filme para entrar na era da fita Umatic. Os jornalistas que foram trabalhar na televisão neste período, na sua maioria, já possuíam formação acadêmica em jornalismo.

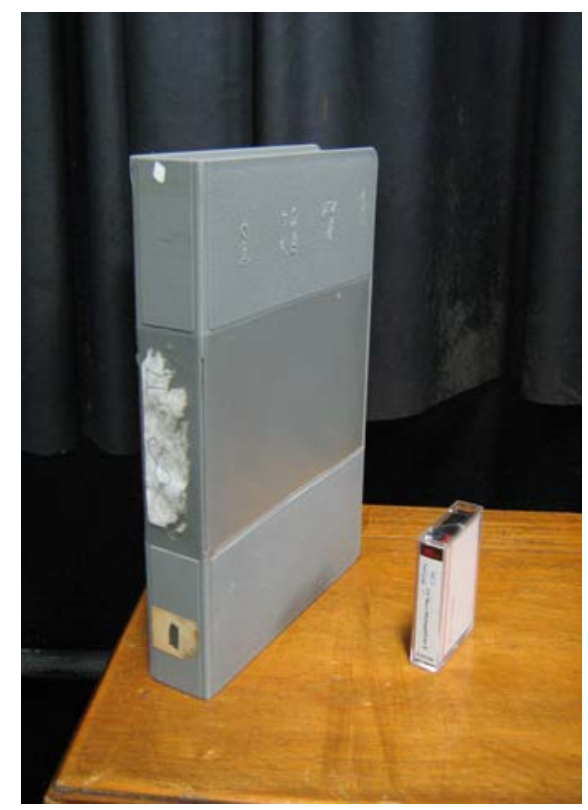

A caixa maior é da fita Umatic, usada nos anos 80 e a menor é da Mini-DV, usada atualmente. 
Uma outra marca registrada desta época é o interesse que os jornalistas de impresso tiveram em trabalhar na televisão. Alguns personagens entrevistados, durante a realização desta pesquisa, são oriundos de veículos impressos, antes de se tornarem telejornalistas. Como foi o caso dos jornalistas Carmen Lúcia Amorin Ferraz Mendes ${ }^{40}$ (Diário Mercantil de Juiz de Fora), Edson Higo do Prado (editora Abril), José Maria Santana (O Estado de S. Paulo e Veja), Luiz Gonzalez (Revista Visão, Veja, Placar), Luiz Antonio Malavolta (Jornal da Cidade - de Bauru), Silvia Poppovic (O Estado de S. Paulo e Diário de São Paulo), Nelson Hoineff (O Jornal, Diário de Notícias, Última Hora, O Globo, Veja e O Cruzeiro), Paulo Markun (O Globo, O Estado de S. Paulo, Jornal da Tarde, Folha de S. Paulo, Jornal da República, Jornal do Norte, Jornal do Povo de Piracicaba e DCl, Revistas Imprensa, Radar e Dead Line), Luiz Carlos Azenha (Jornal da Cidade - de Bauru), Alceu Nader (Veja) e Celso Pelosi (Rudge Ramos Jornal e Notícias Metodista). O único entrevistado desta década que não teve passagem pelo jornalismo impresso foi Amauri Sérgio Soares.

O jornalista José Maria Santana ${ }^{41}$ formou-se na Escola de Comunicações e Artes da USP e começou sua carreira em um jornal no ABC Paulista. Depois de um tempo, foi para a sucursal de O Estado de S. Paulo e, em seguida, para a própria sede da redação do jornal. Teve também uma passagem pela revista Veja e, só depois, foi trabalhar com telejornalismo. Depois de 15 anos dedicados ao impresso, em 1983, ele recebeu um convite dos colegas Raul Bastos e Luiz Gonzalez, que eram, respectivamente, chefe de redação e editor regional da Globo de São Paulo. Naquele momento, eles estavam fazendo uma experiência com pessoas que tinham uma formação jornalística. $O$ objetivo era passar para essas pessoas o formato e a linguagem da televisão. De acordo com Santana, nessa época, o habitual era as pessoas começarem a trabalhar na televisão, portanto, tinham o domínio da linguagem, mas não tinham formação mais profunda, mais sólida, como jornalismo. Mesmo sem experiência em televisão, ele resolveu aceitar o desafio:

\footnotetext{
${ }^{40}$ Conhecida no vídeo como Carmen Amorin.

${ }^{41}$ Entrevista gravada em São Paulo em 01 de novembro de 2006.
} 
Eu tinha 15 anos como jornalista, mas nunca tinha entrado numa emissora de televisão. Comecei como editor de texto de um jornal da hora do almoço. Sem saber nada de televisão, aprendi lá com as pessoas e com o editor-chefe na época, que era o Paulo Roberto Leandro (SANTANA, 2006).

Esse aprendizado, na prática, aconteceu em paralelo com o trabalho na editoria de política do Estado de S. Paulo. Depois de aprender na prática, Santana começou a dedicar-se à informação jornalística e logo passou a editorchefe do Bom Dia São Paulo. Na seqüência, virou coordenador de pauta da Globo de São Paulo, preparando pautas para todos os telejornais da rede. Participou da experiência e implantação do Jornal da Globo, em São Paulo, com a jornalista Lílian White Fibe. Por último, foi chefe de redação da Globo São Paulo, dividindo a direção do telejornalismo com os jornalistas Marcelo Vaz e Paulo Roberto Leandro. O momento vivenciado por Santana dentro da redação da tevê Globo era o período da redemocratização do país, onde, segundo ele, "a Globo tinha uma imagem, até perante a imprensa, perante certa parte da esquerda no Brasil, como uma emissora ligada ao regime na época". Os profissionais que trabalhavam, segundo ele, não aceitavam a posição da empresa:

Eu sinto que, naquela época, a gente tinha muito prazer de fazer as coisas. É evidente que houve fases, por exemplo, Diretas Já. E aquele momento, aquela evolução política, em que a gente teve conflitos internos na Globo. Quer dizer, a nossa posição era mais avançada do que a emissora permitia (SANTANA, 2006).

O que mais incomodava o grupo de Santana eram as restrições à cobertura das Diretas, pois eles queriam, de alguma maneira, participar daquele momento, que era importante para o Brasil. A frustração de Santana aumentava, quando ele trabalhava pela manhã, na tevê Globo, e à tarde, no Estadão. "Era um pouco frustrante; as coisas que a gente acompanhava lá na editoria de política do Estadão e as coisas que a gente não podia fazer na Globo."

Outra marca desta fase é a introdução do uso do "ao vivo" dentro dos telejornais. Começou-se a mudar aquele formato muito fixo do telejornal, com as entradas dos links. Santana participou de uma experiência, que foi a edição de dez anos do Bom Dia São Paulo, quando o jornal foi ancorado, "ao vivo", de um helicóptero. Em paralelo a isso, um grupo de convidados eram 
entrevistados, num hotel em São Paulo, pelo jornalista Carlos Tramontina, do alto do helicóptero. Entre entrevistas e matérias, se desenvolveu a edição comemorativa do telejornal, e, no final, o helicóptero desceu no hotel e o apresentador foi participar do café da manhã com os convidados e encerrar 0 telejornal.

Edson Higo do Prado ${ }^{42}$ também é do grupo que deixou o impresso, para ingressar na televisão, nos anos 80 . Mais precisamente no final de 1982, ele aceitou o convite de Alice-Maria para trabalhar no CPN - Centro de Produção de Notícia, na tevê Globo do Rio de Janeiro. Lá, exerceu as funções de produtor, chefe de reportagem e chefe de redação. Segundo ele, o CPN é um centro integrado, que é um modelo que vem da tevê americana CNN, e se constitui numa ponte entre cabeça da rede e cada emissora afiliada. "Tem um núcleo que se correlaciona com toda a rede e acaba direcionando as pautas, levantando todos os assuntos para aquelas reuniões setoriais pontuais, que são realizadas durante o dia". Antes, porém, Prado havia trabalhado na editora Abril, como outros profissionais, que, naquele momento, foram para 0 telejornalismo. "O grande celeiro para o telejornalismo era o próprio impresso, então, era lá que eles iam buscar a experiência no jornalismo", afirma ele. O aprendizado foi no dia-a-dia. "Como a própria profissão no jornalismo impresso, você pode estudar, pode até saber alguma coisa, mas aprender é só na prática, mesmo." Prado ressalta que a vinda dos profissionais do impresso para a televisão, com mais freqüência nos ano 80, trouxe uma nova cultura, que é a cultura dos grandes veículos impressos, nos quais eles trabalharam. Essa nova cultura, a que Prado se refere, diz respeito à estrutura organizacional da redação, que começou a ficar mais profissionalizada com uma melhor divisão dos cargos e das funções. Surgiu a hierarquia entre o chefe de redação, o chefe de reportagem, o editor-executivo e os editores, mas essa nova estrutura, na tevê, tem um funcionamento inverso ao impresso:

No jornalismo impresso você tem uma hierarquia que é vertical, na televisão, a hierarquia, por mais que você tenha nomes semelhantes, ela é horizontal. E quando eu quero dizer horizontal, não importa onde você esteja nessa cadeia. A importância é a mesma, porque se o motoboy não trouxer a fita, a matéria não vai pro ar (PRADO, 2006).

\footnotetext{
${ }^{42}$ Entrevista gravada em São Paulo em 10 de outubro de 2006.
} 
O texto mais elaborado, trazido pelos jornalistas do impresso, veio contribuir para melhoria da qualidade dos telejornais. "O texto, infelizmente, é acessório, mas, o texto de televisão é muito difícil, porque ele tem que ser substantivo e não pode brigar com a imagem", constatou Prado. Quando ele chegou à tevê, há pouco tinham ocorrido as primeiras eleições diretas para governador, depois da ditadura. A emissora estava se recuperando do episódio, que ficou conhecido como Caso Proconsult, e segundo Prado, havia um mal estar dentro da redação, porque a imagem do jornalismo havia sido desgastada. O Caso Proconsult, resumiu Prado, aconteceu na eleição para governador do estado do Rio de Janeiro, entre os candidatos Brizola e Moreira Franco, quando o TRE contratou a empresa Proconsult, para processar os mapas da eleição. Em paralelo a isso, a Rádio Jornal do Brasil, que tinha o jornalismo dirigido pelo jornalista Procópio Mineiro, resolveu fazer um acompanhamento das urnas, através de estagiários, no estado inteiro. Então começou a haver um conflito: pelo mapeamento da JB, o Brizola estava na frente, pelo mapeamento do Proconsult, o Moreira Franco estava na frente. O caso levou um mês para ser resolvido e a apuração correta dava vitória a Leonel Brizola. Mas esse desdobramento levou a tevê Globo a ficar mal vista perante a opinião pública, porque divulgou os dados equivocados da Proconsult.

Depois de alguns anos, nesta década, a emissora começou a fazer cursos de formação em todo país. "Era um grupo de pessoas que faziam cursos de reciclagem em toda a rede para, na verdade, uniformizar o padrão". É aí que surge o chamado padrão Globo de Qualidade, que atualmente está sendo retomado pela campanha institucional da emissora, mas que surgiu quando a emissora completou 15 anos e constituiu uma rede com 36 afiliadas e 3 emissoras geradoras. A Globo passou a investir na técnica e no conteúdo da programação. Esse momento foi criticado por Artur da Távora, conforme segue:

O chamado 'padrão Globo' de produção é muito discutido, mas pouco conhecido em sua essência. Os detratores da rede confundem 'padrão de produção' com 'conteúdo educativo' ou cultural (no sentido burguês e elitista do termo). Os defensores da rede, ou seus admiradores incondicionais, confundem-no com o que chamam de 'qualidade' dos programas, no sentido de eles 'gostarem' ou não. Padrão de produção, porém, nada tem a ver com qualidade de programa, nos vários sentidos em que o qualificativo é usado (qualidade cultural, educativa, de entretenimento, de emoção, de estética etc.). Padrão de produção é a criação de rotinas internas e de equipes técnicas capazes de realizar, a nível industrial, isto é, com regularidade e freqüência, programas que 
atendam: A) a necessidades manifestadas do mercado; B) a dinâmicas de comunicação que despertem a atenção mantenham-na e consigam níveis altos de emoção, adesão e sentimento; C) a necessidades de clareza do mercado e simplicidade no contato com idéias novas; D) a necessidades de entretenimento com base no princípio do prazer, marco fundamental da atitude do telespectador; E) a necessidades de informação e conhecimento dos problemas da comunidade; F) as necessidades de exercícios interiores de emoção projetados em figuras de ficção; G) a necessidades de fantasia e devaneio principalmente entre as crianças; H) a um mínimo de qualidade técnica; I) a um mínimo de qualidade estética; J) a consonância com os valores éticos médios aceitos pelo público; K) à necessidade de existência, para faixas etárias presentes na audiência, de matérias compatíveis com suas várias preferências e aspirações. Isso é padrão de produção: a obtenção de todos esses elementos na média da programação. É um patamar comum a toda programação, que mistura vetores diferentes no atendimento a necessidades subjetivas do mercado. É um produto novo, típico da era eletrônica (MELLO E SOUZA; 1984: 67 - 68).

Depois de alguns anos, Prado trabalhou na Abril-Vídeo e na tevê Manchete. Em 1983, na Abril-Vídeo participou de uma tentativa inovadora da Editora Abril de fazer televisão. Foi o São Paulo na TV, onde a editora comprava horário na tevê Gazeta de São Paulo e produzia programa telejornalístico. O único problema era conviver com a falta de estrutura técnica para colocar o jornal no ar todos os dias: "você não tinha recursos, e, portanto, você tinha que usar a criatividade". O projeto era dirigido por Luiz Fernando Mercadante e Chico Santarita, e contou com jornalistas como Paulo Markun, Silvia Poppovic e Caco Barcellos, mas teve curta duração, porque a Editora Abril simplesmente decidiu não investir mais em televisão ou devido à negativa que recebeu para obter uma concessão pública de tevê.

Luiz Zinger Gonzalez ${ }^{43}$ também trocou dez anos de experiência em jornalismo impresso, em veículos como Manchete, Veja, Placar, Gran Pri, Visão, Agência Telenotícias, Jornal da República e Editora Três pelo telejornalismo. Formado em jornalismo, pela Fundação Armando Álvares Penteado - FAAP, de São Paulo, nos anos 70 aceitou o convite de conhecer pessoalmente a operação do Jornal Hoje, no Rio de Janeiro. A primeira observação, relata ele, foi um desastre, pois aquele era o dia do julgamento do Jorge Kour - um cabeleireiro acusado de matar a modelo Claudia Lessin Rodrigues. A matéria da cobertura do julgamento foi anunciada na escalada e no primeiro bloco, depois do apresentador Berto Filho ler a cabeça, a matéria não entrou e sim um slide de segurança que ficava sempre pronto para cobrir

\footnotetext{
${ }^{43}$ Entrevista gravada em São Paulo em 29 de novembro de 2006.
} 
as falhas. No segundo bloco, depois de toda a repaginação do jornal, a matéria é chamada novamente e não entra. No terceiro bloco, acontece a mesma coisa. Depois dessa observação dramática e das discussões que ocorreram na redação e, ainda, da frase célebre da jornalista Alice-Maria: "televisão, quando você termina o seu trabalho, não quer dizer que o trabalho tenha terminado, você tem que calcular a seqüência do que acontece depois de você", ele foi para o telejornalismo. Pois, mesmo sendo uma experiência ruim, "acabei indo, porque a televisão é um pouco viciante, você se vicia em televisão, principalmente com essa adrenalina dos telejornais diários”. Quando ele foi se despedir dos seus superiores, na revista Veja, antes de assumir o trabalho na televisão, o diretor de redação, que na época era o Guzu, e o diretor-adjunto, que era o Elio Gaspari, ele percebeu o quanto o telejornalismo era desacreditado, pois eles perguntaram se ele iria mudar de profissão. Gonzalez rapidamente respondeu que não, porque ia trabalhar no jornalismo. Guzu falouIhe: "mas a Globo não tem jornalismo, porque você conhece algum furo que a tevê Globo tenha dado, alguma matéria importante, não existe". Chateado, Gonzalez aceitou aquilo como um desafio. Para ele, também não houve treinamento específico para trabalhar no telejornalismo. A única coisa que conseguiu fazer, além de observar a rotina, foi um curso de uma semana de edição de imagens: "eu pedi isso porque foi útil, pois consegui entender qual era a mecânica, como é que as palavras se transformavam em fita." Assim, ele assumiu como subeditor chefe do Jornal Hoje, com a tarefa de montar o jornal. Antes, tinha que ver com as várias editorias do Brasil inteiro, o que tinha de notícia e combinar com os editores a geração das matérias. Na ausência do editor chefe, ele o substituía. Depois de um ano, ele recebeu uma proposta de trabalho da tevê Bandeirantes para ser chefe nacional de redação e resolveu voltar para São Paulo. A experiência durou pouco tempo, porque as condições de trabalho na Bandeirantes eram precárias. A redação da tevê funcionava junto com a rádio e Gonzalez teve que mudar aquela situação. O jornal não tinha uma lauda padrão e era rodado em estêncil, porque o xérox era muito caro. "Fizemos uma lauda, adotamos o xérox, adotamos uma colméia, que eram uns quadrados que ficavam na parede e onde você punha as laudas que ficavam prontas”. Depois de um tempo, Gonzalez conseguiu mudar a redação de lugar. Mas a gota d'água foi cobertura de carnaval de 1982, onde a 
emissora resolveu ficar no ar os 4 dias de programação e transmitir o carnaval do Rio de Janeiro, sem ter muitas condições técnicas e usando imagens de outras emissoras e emprestando cabos. "Foi um negócio totalmente precário, muito engraçado de falar agora, mais um stress absurdo". Depois disso, ele voltou para tevê Globo, para ser chefe de redação do Globo Repórter, onde os cineastas estavam sendo substituídos pelos repórteres e os documentários pelas grandes reportagens. No período que antecedeu as eleições de 1982, ele produziu uma série de programas, como o Momento do Voto, e os debates, visto que o Globo Repórter ficou fora do ar. Um manual foi apresentado aos jornalistas da emissora: "era um produto impresso, que se chamava Manual das Eleições, que tinha sido copiado da CBS americana. Era um livrinho, com informações para os repórteres e editores que iam cobrir eleição."

Uma outra novidade dos anos 80 é a regionalização dos telejornalismo, feita inicialmente pela tevê Globo, no estado de São Paulo, que depois serviu de base para o país todo. A emissora dividiu o estado em macro regiões e criou espaços regionais na programação para os telejornais nas áreas dividas, como Oeste-Paulista, Sudeste Paulista, Noroeste Paulista, entre outros.

$\mathrm{Na}$ região com sede em Bauru, denominada Oeste Paulista, havia a cobertura de 258 cidades, entre São José do Rio Preto, Presidente Prudente, Marília e Araçatuba. Essa foi uma experiência pioneira em telejornalismo regional.

Desta fase, o jornalista Luiz Antonio Malavolta ${ }^{44}$ foi um dos primeiros contratados pela emissora para fazer uma série de trabalhos. "Tinham várias definições: você é repórter e também apresenta, você é repórter e também faz chefia de reportagem, você é repórter e também edita, havia um acúmulo de funções". Isso, segundo ele, dava experiência para depois poder trabalhar na sede, em São Paulo, que era o sonho de todo jornalista do interior. Na época de sua contratação, houve uma seleção para encontrar pessoas da cidade que tivessem jeito para televisão. "Então, como foi muito fácil o teste, acabei sendo selecionado." Também foi levada em conta sua experiência em rádio e em jornal impresso. Os requisitos básicos eram que as pessoas tivessem o mínimo de capacidade e postura no vídeo e boa narração. Em seguida, os

\footnotetext{
${ }^{44}$ Entrevista gravada em São Paulo em 25 de julho de 2006.
} 
selecionados fizeram um treinamento em São Paulo. Malavolta começou como repórter, foi apresentador e depois acabou optando pela chefia de reportagem. A equipe tinha 20 pessoas, entre jornalistas e técnicos, e produzia, diariamente, de segunda a sábado, o Jornal das Sete, com 7 minutos de duração. O maior impasse deste grupo era dar notícias que interessassem à toda a área de cobertura da emissora, tendo apenas duas equipes de reportagem. "As notícias de Bauru não interessariam para Araçatuba, não interessaria para outra região. Então, a gente procurava todo dia fazer uma viagem pra pegar o principal assunto da região. Dava muita nota e nota coberta". Mesmo com estas condições, a equipe recebeu vários prêmios e até um Vladimir Herzog. Depois de um tempo, a equipe cresceu e passou a contar com a participação de sucursais em algumas cidades, como Marília e Presidente Prudente. Houve também a contratação de um apresentador para o telejornal. $\mathrm{O}$ até então radialista, Gilberto Barros ${ }^{45}$, passou a fazer parte da equipe. Outro problema enfrentado pela equipe era a impossibilidade de colocar o jornal no ar, ao vivo. Eram gravadas as cabeças às 5 e meia da tarde, depois era editado e levado para o transmissor, que ficava a 12 quilômetros da emissora: "o que acontecesse depois desse horário, não dava pra colocar no jornal." Dessa época, Malavolta recorda uma passagem que quase deixou o jornal fora do ar: "teve um dia que o carro que estava levando a fita furou $o$ pneu no meio do caminho, e, aí, o garoto que era office-boy na redação pegou a moto dele e saiu correndo e conseguiu entregar a fita no último minuto". Os jornalistas do interior tiveram, além do treinamento, acesso ao primeiro manual de telejornalismo da emissora, que segundo Malavolta "tinha considerações de como fazer enquadramento, como fazer imagens numa reportagem, qual o tipo de linguagem que deve ser usada e tinha um padrão de texto baseado na linguagem coloquial." Este manual será mais bem explicado mais adiante. Malavolta admite que os manuais ajudam, mas que o verdadeiro aprendizado só é possível ao longo dos anos:

O jornalista que vem trabalhar em televisão, tem que passar por um processo todo de aprendizado, que a universidade não consegue dar. $\mathrm{E}$ acho que a universidade do mundo inteiro não tem condições de

\footnotetext{
${ }^{45}$ Conhecido hoje em dia como Leão faz apresentação de programa de entretenimento na tevê Bandeirantes e está muitos quilos mais gordo. Na época ele foi considerado o primeiro apresentador de telejornal a utilizar bigode.
} 
passar, porque se faz no dia a dia. É no treinamento diário, no fazer diário, que você acaba aprendendo fazer televisão (MALAVOLTA, 2006).

Algumas constatações relativas ao caráter visual da televisão ele julga serem fundamentais para se poder compreender melhor o processo de transmissão de informação televisiva:

\begin{abstract}
A televisão é uma coisa muito estética, a pessoa não pode ficar mal ajambrado, não pode ir com a barba por fazer, com o cabelo mal feito, com a roupa toda amassada. Tem que sorrir, tem que cativar as pessoas que estão em casa. Tem uma coisa assim de teatralização, também. (MALAVOLTA, 2006)
\end{abstract}

Para Malavolta, a televisão é um trabalho fundamentalmente de equipe: "em televisão não se usa eu, se usa nós, nós fazemos televisão, é um trabalho em conjunto. Ninguém é melhor que ninguém na televisão, todos tem um trabalho muito específico e conjunto."

Luiz Carlos Azenha ${ }^{46}$ também começou a sua carreira de telejornalista no oeste paulista. Foi escolhido para ser repórter, devido à sua experiência no impresso, também passou por um treinamento, segundo ele básico, para iniciar o trabalho: "a gente estava muito aquém do padrão que se espera, hoje, de uma emissora de televisão, até no vestuário." Quando ele se refere ao vestuário, diz respeito a algumas críticas, devido ao grande número de notícias de Bauru, que eram exibidas no telejornal, em detrimento de outras cidades. Isso levou uma escritora de São José do Rio Preto a chamar os repórteres da tevê Globo Bauru de maltrapilhos. Mas o aprendizado também foi acontecendo na prática e nas coberturas de férias, na cabeça da rede: "em passei a vir muito cobrir férias de repórteres da tevê Globo de São Paulo e tive a minha primeira experiência com o treinamento, com a Glorinha Boite Muller, que determina a questão da fono." Isso fazia com que ele sofresse críticas dentro da própria emissora e trabalhando. Azenha percebe a grande diferença do passado para os dias de hoje, porque no início não havia muito critério. Quando a matéria chegava, era só editar e pronto. "Antes, não tinha tempo, a matéria chegava, editava e olha aí. Dificilmente olhavam o seu texto, porque era tudo na correria. Tinha que estar no ar e não tinha tempo." Hoje, com a evolução da tecnologia, é possível produzir uma matéria com rapidez e estar em contato com a

\footnotetext{
${ }^{46}$ Entrevista gravada em São Paulo em 31 de outubro de 2006.
} 
redação, através do lap-top. "Você pode estar trocando informações ali e, ao mesmo tempo, entrando na internet, checando um dado, que está no seu texto. Isso abre a possibilidade pra que muita gente, não é que palpite, mas influencie o texto, que vai ao ar em seu nome". São os dois lados da moeda, que, com a evolução tecnológica, o repórter tem possibilidade de errar menos e, por outro lado, a reportagem autoral acaba deixando de existir. Azenha, nos anos 90, deixou a tevê Globo e retomou o curso de jornalismo, que havia deixado na década passada. Nesta época, foi trabalhar na tevê Manchete, em São Paulo. Logo depois, passou a ser correspondente internacional:

Fiz uma cobertura, que acho que foi bacana, com um grupo de pessoas sobre a eleição de São Paulo. Aquela que o Jânio ganhou do Fernando Henrique, de surpresa. Depois, uma série de coincidências. Eu falava inglês. E o correspondente decidiu sair (AZENHA, 2006).

Para ele, correspondente deve traduzir para o Brasil a notícia, com uma visão brasileira do processo, mas não é o que acontece hoje: "está havendo uma banalização da correspondência". E um dos fatores para essa banalização, segundo Azenha, é um achatamento salarial, que faz com que as emissoras enviem gente cada vez mais jovem e com pouca experiência, e, muitas vezes, sem nem dominar o idioma. Outra grande mudança que ele observa na profissão do correspondente é a falta de liberdade e de autoria nas matérias. "Na Manchete, eu tinha uma liberdade maior. Eu escrevia, fazia tudo, mandava e ia ao ar, era minha matéria." Isso acontecia em 1988. Ao todo, Azenha ficou 16 anos como correspondente internacional, sendo 13 anos pela Manchete e 3 pela Globo, depois de ter voltado por um curto período para o Brasil. Na última fase, como correspondente da tevê Globo, houve casos em que o editor de um telejornal, em São Paulo, define o que o correspondente vai dizer sobre o mundo lá de Nova lorque: "o cara por e-mail, eu acho que essa frase aqui não tá legal... você tem esse centralismo muito grande, que é contraditório com a expansão da comunicação pela internet, é um choque", concluiu ele.

Marcos Gomide ${ }^{47}$ foi o primeiro correspondente da sucursal de Marília da Rede Globo Oeste Paulista. Depois de ter tentado, desde 1984, fazendo testes, em 1987 Gomide foi contratado para ser repórter da sucursal.

\footnotetext{
${ }^{47}$ Entrevista gravada em Fortaleza em 16 de março de 2007.
} 
Experiência ele já possuía em rádio, desde os 14 anos, e também no impresso, no Correio de Marília. Para ele, a exigência básica era um pouco de narração, vídeo e de conhecimento das técnicas de jornalismo:

O que pesou foi à contratação de pessoas que estivessem morando na cidade de Marília. Quando foi implantado o projeto Rede Globo Oeste Paulista, muita gente vinha de fora, de São Paulo, Rio, Minas, para trabalhar no interior. Ficavam um período, depois queriam voltar. Por isso, a emissora escolheu pessoas da cidade para trabalhar, porque imaginava que elas fossem ter, assim, maiores raízes e sem aquele desejo de troca muito grande, em pouco tempo (GOMIDE, 2007).

Gomide chegou há ficar um mês em Bauru, por conta da TV, mesmo sem ser contratado para fazer uma adequação, um período de adaptação para a televisão. Para ele, o mais difícil foi adequar a narração do rádio para a televisão. Também sentiu a necessidade de adequar o texto de jornal e de rádio para a televisão. Dentre as dificuldades encontradas, no início da carreira, ele ressalta a falta de estrutura com relação ao figurino, à maquiagem e, principalmente, à falta de um profissional para cuidar da voz. Ele trabalhou na reportagem até 1999, quando foi trabalhar na sucursal de Presidente Prudente, como gestor na área de jornalismo e, depois, mais tarde, em São Paulo, na área de coordenação de afiliadas. Está há seis anos como diretor de jornalismo da tevê Verdes Mares, em Fortaleza, no Ceará.

No começo de 1985 a Rede Globo Oeste Paulista passou por uma grande reformulação, onde o jornalista Celso Pelosi ${ }^{48}$ também foi contratado, como editor-assistente. Depois de ficar, das 10 às 17 horas, esperando para uma entrevista com editora regional Neusa Rocha e o diretor de jornalismo Raul Bastos e, ainda ficar três dias editando experimentalmente, ele conseguiu a vaga. Mesmo nunca tendo trabalhado em emissoras de tevê, Pelosi fez cursos complementares e trabalhou no estúdio da faculdade (Metodista de São Bernardo do Campo), onde estudou jornalismo. Também estava lecionando telejornalismo na Universidade de Bauru (atual Unesp). Sua experiência era em jornal:

A prática como repórter, editor e orientador de estágio do Rudge Ramos Jornal (editado pela Metodista) também ajudou a minha formação de editor. Embora impresso, o jornal usava uma linguagem direta, objetiva e coloquial, próxima à linguagem do rádio e da TV. Os

\footnotetext{
${ }^{48}$ Entrevista realizada via internet em 06 de fevereiro de 2008.
} 
títulos eram todos no presente do indicativo, por exemplo (PELOSI, 2008).

Como não havia muitos profissionais com experiência em tevê, o que contava mais era a experiência em jornalismo, de um modo geral, rádio, jornal e revista. O rigor com o texto também ajudou-o a entrar na tevê. Uma das características desta época foi preocupação com a forma e não com o conteúdo. "A censura havia acabado, mas deixara resquícios. Implicitamente, alguns colegas e chefes faziam a autocensura. Logo, não havia muita reflexão crítica sobre o conteúdo. Havia, sim, uma obsessão pelo formato, pela precisão operacional." Como a emissora ainda não havia resolvido todos os problemas técnicos, todas as reportagens e notas-cobertas vinham acompanhadas de um texto de emergência. Se ocorresse algum problema técnico operacional, que impedisse a exibição da reportagem, o apresentador sacava o texto de emergência e lia como nota. "Certa vez, o VT da agenda cultural não ficou pronto e o Gilberto Barros leu uma imensa nota de três minutos. Haja fôlego!" Depois, no final dos anos 80 , os repórteres começaram a ter mais liberdade de criação: "O terno, que era obrigatório, passou a ser usado apenas em ambientes internos. Implantou-se a passagem participativa, em que o repórter interage com o tema". Avanço de um lado, mas um atraso técnico do outro, pois, ainda no início dos anos 90, a emissora de Bauru não tinha gerador de caracteres, nem teleprompter. "Os caracteres eram feitos em letraset (decalques). Não havia computadores, de modo que a tecla delete era o famoso "branquinho", o corretivo ou a velha caneta futura (ponta grossa). Muitas vezes a correção era manuscrita e o apresentador que se virasse". Uma observação muito importante de Pelosi é que até meados da 90 , as redações eram mistas, mais ou menos, $50 \%$ de homens, $50 \%$ de mulheres. "De lá pra cá, as mulheres vem tomando conta das redações. Hoje, é difícil encontrar repórteres homens, prontos para o vídeo". Outra observação dele é relativa ao perfil do telejornalista, a partir dos anos 90: "o perfil começou a migrar de especialidades para generalidades. Quer dizer: deixamos de buscar repórter, apresentador, editor, produtor, e passamos a procurar e/ou formar um profissional multifuncional". Isso, sobretudo nas emissoras dos centros médios e pequenos (exceto cabeça-de-rede), mudou a clássica divisão da redação por setores em um único setor: 
Apuração/escuta/pauta/chefia de reportagem/edição ficou mais enxuta: apuração/escuta/pauta/chefia de reportagem se fundiram num único setor - o de produção. $\mathrm{Na}$ edição os antigos apresentadores se transformaram em editores-chefes ou editores-apresentadores; repórteres também passaram a apresentar telejornais e/ou programas (PELOSI, 2008).

Assim tornou-se comum um produtor apurar, pautar, reportar, editar a apresentar. O fenômeno mais recente é que este profissional, atualmente, também está editando imagens. "Com a digitalização da edição, ficou mais fácil e rápido editar. Ao montar o esqueleto, o editor também pode selecionar as imagens", comenta Pelosi. Ele continuou em Bauru até 1988, quando foi convidado a assumir a direção de jornalismo da TV Morena no Mato Grosso do Sul. Depois, trabalhou como chefe de redação da Rede Globo Vale do Paraíba, em São José dos Campos. Voltou a Bauru, em 1990, como editor regional, e em 1998, assumiu a direção-executiva da então Rede Globo Noroeste Paulista e atual TV Tem, em São José do Rio Preto. Desde 2005, é diretor regional da TV Tem, de Sorocaba.

O jornalista Alceu Nader $^{49}$ se formou em jornalismo na FAAP (Fundação Armando Álvares penteado), na década de 70. Começou a trabalhar como repórter-pesquisador do Guia Quatro Rodas. Depois, foi para a Europa, onde mandava matérias para $O$ Estado de $S$. Paulo. De volta ao Brasil trabalhou na sucursal do $\mathrm{ABC}$, do jornal. Na seqüência, foi copidesque de variedades do Jornal da Tarde. Chegou a trabalhar, também, na revista Veja. Em 1984, resolveu deixar a revista Veja, onde havia passado três anos como correspondente na Argentina, pelo trabalho em televisão: "eu queria aprender como é que era, e coincidiu de me convidarem para aprender na Rede Globo de Televisão de São Paulo." Ele passou dois anos como editor de texto e depois acendeu para a chefia de reportagem. Como sua experiência anterior era no impresso, teve que aprender fazendo: "aprendi na prática. Tinha texto e tinha noção de como a notícia deveria ser tratada, mas eu ainda não tinha nenhuma formação específica de edição. Aprendi tudo no dia-a-dia." Depois, foi convidado a abrir os escritórios da Rede Globo Oeste Paulista em Bauru, Marília, Araçatuba e São José do Rio Preto:

${ }^{49}$ Entrevista gravada em São Paulo em 18 de abril de 2008. 
Tinha que tentar contratar jornalistas e explicar a diferença que seria a partir dali. Era uma época, ainda, e hoje não deve ser muito diferente, em que os jornais desses municípios dependiam muito dos editais da prefeitura para sobreviver. Então tinha que mostrar, tinha que deixar claro o poder que ele tinha, a partir dalí (NADER, 2008).

Sobre o trabalho que realizou durante a implantação da Rede Globo Oeste Paulista, com a central na cidade de Bauru, ele revelou que, na maioria das praças a escolha se devia ao fator econômico, ou seja, em primeiro lugar, as maiores praças publicitárias. Mas, no caso de Bauru, outros fatores foram determinantes, como o fato da cidade ser o maior entroncamento rodoferroviário ${ }^{50}$ do interior do estado, e, também, por já possuir uma sede própria - a tevê Bauru. "Foi montada a rede, tendo Bauru como centro. Dalí, saía pra Prudente, Marília, pra Rio Preto e pra Araçatuba. Depois, redesmembraram e fizeram a Rede Globo Noroeste Paulista na época." Uma das recordações que guarda deste período é relativa à estrutura antiga e precária que a emissora possuía, com câmeras dos anos 60 e 70. "O teleprompter era um cabo de vassoura, montado num tripé, aonde tinha um boy, que detinha toda essa tecnologia. Ele colava todas as laudas, e ia girando com uma manivelinha a folha de papel, tinha uma lente na frente." Mesmo com tantas limitações técnicas, a emissora realizou alguns feitos inéditos. "Nós fizemos a primeira transmissão ao vivo, lá da tevê Bauru. Foi a minha estréia lá, inclusive. Foi no carnaval de 1985." Outras informações deste período que ele relatou, foram relativas à censura, que naquele momento era interna, ou como alguns autores chamaram, de autocensura. "Era proibido veicular o nome do Dom Elder Câmara, por exemplo, e tinha proibições freqüentes de povo-fala sem sonora. Não podia ter ruído de manifestação de greve, essas coisas todas." Ao longo de um curto espaço de tempo, o jornalista Alceu Nader desistiu da carreira em televisão. "O meu encantamento com a televisão durou 2 anos só, porque com toda a instantaneidade, a característica do veículo

\footnotetext{
${ }^{50}$ Atualmente, Bauru é considerado o maior entroncamento rodo-hidro-ferroviário do interior da América Latina. O município tem ligação com a capital, através do complexo Marechal Rondon - Castelo Branco, com pista duplicada em todo o percurso. Os principais acessos rodoviários são SP-294 (ligação com Marília) e SP-255 (ligação com Ribeirão Preto). Com a privatização dos sistemas ferroviários, espera-se a recuperação física de seu sistema e a consolidação de seu papel no desenvolvimento da região. O município também está situado a $25 \mathrm{~km}$ do Porto Intermodal do Rio Tietê, em Pederneiras, na hidrovia Tietê - Paraná.
} 
etc..., eu tinha formação revisteira. Eu queria ir mais fundo no texto e, isso só era possível em um programa, que era o Globo Repórter."

O jornalista José Carlos Aronchi de Souza ${ }^{51}$ também participou de todo o processo de regionalização do telejornalismo, pelo interior de São Paulo, trabalhando na Rede Globo de Bauru. Quando chegou à emissora, era recém formado, mas já havia trabalhado na parte técnica de televisão. Formou-se em jornalismo pela Metodista de São Bernardo. Antes, trabalhou como repórter fotográfico e redator em jornal impresso e atuou em produtoras de vídeo. Durante sua carreira, exerceu quase todas as funções da área técnica. Foi operador de câmera, operador de VT, sonoplasta, operador de áudio, editor de imagens e supervisor de operações. Em paralelo à sua atuação profissional, Aronchi também ministrava aulas em universidades. Nos anos 80 , lecionou telejornalismo na UNESP de Bauru. Depois, participou da implantação de canais universitários em quatro instituições: UMC - Universidade de Mogi das Cruzes, Universidade Católica de Santos, Universidade Metodista de São Bernardo e Uninove. Para ele, importante é a combinação entre a teoria e a prática. "Nas minhas aulas, eu sempre me pautei por um princípio - eu quero ensinar aquilo que eu estou fazendo. Então, eu sempre procurei ter um pé no mercado, em toda essa minha trajetória." Durante o processo de implantação da Rede Globo Oeste Paulista, Aronchi revelou ter aprendido lições levadas para o resto de sua carreira:

Eu tive esse privilégio de acompanhar esse desenvolvimento, ao mesmo tempo, que eu me desenvolvi, porque eu era recém formado, numa emissora padrão, numa emissora que foi implantada dentro de uma filosofia de regionalização da TV Globo. Eu nem me dava conta da importância daquilo (ARONCHI, 2008).

Aronchi teve a sua formação profissional, de duas maneiras distintas, pois trabalhou na técnica e na produção de conteúdo. "A área operacional, eu aprendi na prática, operando equipamentos e trabalhando com outras pessoas. A parte de produção jornalística de conteúdo, eu aprendi, realmente, na faculdade." Mas todo o seu aprendizado foi complementado com a atuação na Rede Globo Oeste Paulista. "Quando eu fui trabalhar na Rede Globo, lá eu tive um aprendizado, que a gente pode chamar, assim, profissional e organizacional, porque lá é que se desenvolve a indústria da televisão." No

${ }^{51}$ Entrevista gravada em 5 de setembro de 2008 em Natal - RN. 
período em que trabalhou na tevê Globo de Bauru, Aronchi vivenciou o momento da redemocratização do país, onde a autocensura ainda era latente dentro das redações. Ele pôde vivenciar um caso, em que o tema reforma agrária era muito policiado pelos próprios jornalistas da redação:

Um bispo da região de Bauru comentava, numa entrevista, que a igreja católica detém muita terra no Brasil, e que na opinião dele a própria igreja podia dar um bom exemplo, distribuindo terras. Essa matéria foi editada, inicialmente, com 1:30 para o SP 1 e não foi exibida. Depois foi editada com 1 minuto para o SP 2, e, também, não foi exibida. Só foi exibida no SP 3 , com 40 segundos, devido às controvérsias e polêmicas que ocorreram na redação (ARONCHI, 2008).

$\mathrm{Na}$ área acadêmica, em paralelo com a atuação profissional, Aronchi também trabalhou na tevê Cultura de São Paulo, onde teve a oportunidade de conhecer o segmento educativo de televisão. "Eu pude conhecer a divisão dos departamentos de conteúdo. Eram os departamentos de variedades, infantojuvenil, musical, documentários e jornalísticos." Desta experiência, surgiu a dissertação de mestrado sobre os gêneros na televisão - Gêneros e formatos na televisão brasileira.

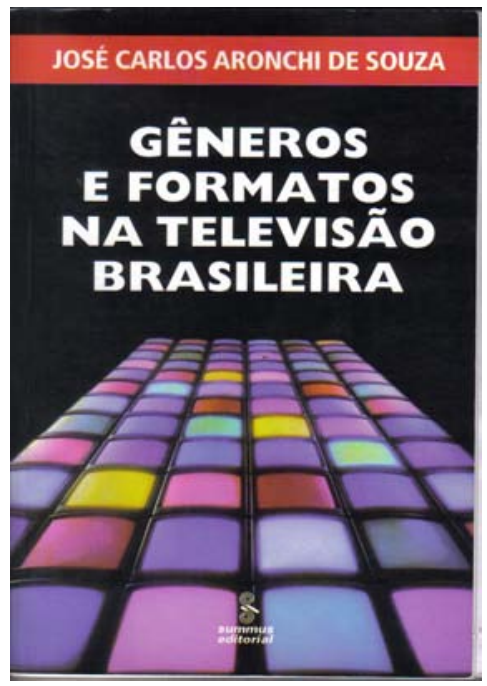

A dissertação de mestrado de Aronchi

Um outra marca do processo de redemocratização do país foram os programas de entrevista, que surgiram como uma forma de verbalizar, para o país, temas polêmicos que, até então, eram censurados. A jornalista Silvia Poppovic $^{52}$, que formou-se em jornalismo na Escola de Comunicações e Artes da USP, também migrou do impresso para a televisão, nesta fase. Foi repórter,

\footnotetext{
${ }^{52}$ Entrevista gravada em São Paulo em 12 de dezembro de 2006.
} 
editora, mas foi como apresentadora e mediadora do programa Canal Livre, na rede Bandeirantes, que marcou sua presença. "Já apresentei programas de debates, eu talvez seja uma das profissionais com maior número de horas de programação, de programas ao vivo". Um dos fatores que a adaptaram rapidamente à televisão, foi facilidade que ela tinha para falar bem e de maneira natural. "Naquela época, você tinha que ter expressividade e tinha que ser uma pessoa com conteúdo, porque, imagine que a gente foi jogada nessa maluquice que foi esse programa, com um microfone na mão, e se eu não tivesse o que dizer?" Além dessa facilidade natural de Poppovic, ela também buscou especializar-se em cursos na News Course Social Research e na Columbia University. "Eles, às vezes, te abrem a consciência para questões até mais relevantes, que a faculdade mesmo tem que ensinar, porque, na prática, você acaba aprendendo." .Como todo início, ela é sincera ao relatar que, mesmo com a facilidade de se expressar, suas primeiras aparições foram tensas. "Eu ficava tão nervosa pra falar, mas eu pegava o microfone e eu tremia, aí, para não dar bandeira, que eu tava tremendo, eu segurava o braço e continuava a tremer. Aí começava a suar e o microfone escorregava". O programa Canal Livre se propunha a debater algum tema, ouvindo os vários lados da questão. "Foi um programa muito bem sucedido, de muito sucesso e era muito polêmico, tinha uma gritaria", recorda Poppovic. Ela ficou até conhecida por não deixar as pessoas falarem muito, devido a essa multiplicidade de opiniões que se propunha a ouvir. Além de apresentar, ela tinha que funcionar como mediadora também:

Se o programa não tava quente, eu tinha que por fogo. Se o programa tava quente demais, eu tinha que ser bombeiro e abaixar o fogo. Então, eu tinha uma responsabilidade de fazer daquela discussão uma coisa acalorada, porque todos nós ficamos calados por tantos anos. (POPPOVIC, 2006)

Depois, com o tempo, os debates e as discussões dos temas polêmicos foram arrefecendo. Então, foi preciso mudar o estilo do programa e acompanhar os novos tempos:

Marcante foi descobrir que as pessoas não queriam, assim, tantas discussões a respeito, depois de tantos anos. Foi quando eu comecei a fazer um programa com um viés psicológico, trazendo psicanalistas, médicos, e comecei a mostrar, como, no fundo, havia uma grande revolução pra acontecer de dentro pra fora. (POPPOVIC, 2006) 
Poppovic ficou 13 anos com o Canal Livre no ar e também teve passagem pela tevê Globo, Cultura e SBT.

O jornalista Paulo Markun ${ }^{53}$ começou mais efetivamente a trabalhar em televisão, em 1981, mas, nos anos 70 , teve uma rápida passagem pelo jornalismo da tevê Cultura, de São Paulo. "Na verdade eu comecei em 1975, quando fui trabalhar com Vladimir Herzog, na tevê Cultura. Fui chefe de reportagem por um mês." Antes e depois deste período, trabalhou em jornais como a Folha de S. Paulo, O Globo, O Estado de S. Paulo, Jornal da Tarde, Jornal da República, Jornal do Norte, Jornal do Povo, Jornal de Piracicaba e $D C l$, e revistas, como Istoé, revista Imprensa, Radar e Dead Line. Markun foi trabalhar na televisão porque não havia emprego no Rio de Janeiro e por ter sido demitido do jornal $O$ Globo. Naquela época, ele recorda que a tevê Globo já era o principal veiculo de comunicação e, como surgiu uma oportunidade para fazer um teste para uma vaga no jornalismo, ele foi. "Eu fiz o teste, não fui muito bem, mas acabei conseguindo uma posição lá, no Fantástico." Durante um ano, trabalhou como repórter, mas não aparecia no vídeo. "Eu ia entrevistar as pessoas, fazer parte de matérias, mas eu não fazia vídeo." Depois, passou um período no RJTV, no SPTV e, finalmente, foi repórter do JN. Antes de entrar para o telejornalismo, Markun confessa que nunca tinha pensado em trabalhar na televisão. Foi a necessidade e a falta de emprego que o levaram para este caminho. "Na frente da câmera, não passava pela cabeça essa idéia e foi muito difícil encarar, eu sou uma pessoa tímida. Eu precisei de muita ajuda." Essa ajuda, ele admite que recebeu da fonoaudióloga que atendia os jornalistas da Globo, a Glorinha Boite Muller "Ela fez um trabalho muito interessante, no meu caso específico, porque eu precisei superar dificuldades." Além da ajuda da fonoaudióloga, Markun reconhece, também, a importância do trabalho em equipe, porque não havia treinamento profissional. "Durante um ano, eu viajei com uma equipe dirigida por um câmera-man, Nelson Gouveia, que era o melhor da tevê, na época, mais experiente." Quando trabalhou na tevê Globo de São Paulo, Markun recorda que havia um grupo de jornalistas, que tinha vindo da imprensa escrita para a televisão, e que este grupo fez a diferença, com um jornalismo atuante e com uma grande escola prática.

${ }^{53}$ Entrevista gravada em Fortaleza, em 25 de maio de 2007. 
"Profissionais como Dante Matiusse, Luiz Fernando Mercadante, Raul Bastos, Woile Guimarães e Francisco Pinheiro imprimiram uma nova marca ao jornalismo da Globo, com muita qualidade, com muita busca de aperfeiçoamento." Dentre as funções que ocupou na televisão, além de repórter, foi apresentador (Abril Vídeo - São Paulo na TV e SPTV), comentarista político (São Paulo na TV), comentarista econômico (Jornal da Globo), editor-chefe e supervisor de programas (São Paulo à Tarde - tevê Record), editor-chefe (Jornal da Manchete São Paulo), diretor e apresentador (Fogo Cruzado e Questão de Ordem - tevê Gazeta e Roda Viva tevê Cultura) e, desde 2007, é presidente da Fundação Padre Anchieta que engloba as emissoras de rádios e a tevê Cultura de São Paulo. Dos anos 80 até os dias atuais, Markun acompanhou toda a evolução tecnológica pela qual passou a televisão brasileira. O que mais o impressiona é a redução do tamanho e dos custos dos equipamentos, pois, no período em que começou sua carreira como telejornalista, havia uma configuração totalmente diferente, tanto com relação ao tamanho da equipe quanto dos equipamentos utilizados,

Quando eu saía pro Fantástico, a equipe era formada por câmera, um operador de som, um operador de luz, um motorista e um carregador de vídeotape, porque o vídeotape era tão pesado e tão grande e ele tinha que levar baterias de caminhão nas costas, pesava 25 quilos essa tralha e havia uma pessoa que transportava isso. Hoje, várias vezes eu fiz matéria, já viajei a América Latina inteira com uma câmera só, eu e ele, os dois carregando todo o equipamento. (MARKUN, 2007)

Marco Antonio Camargo Nascimento ${ }^{54}$ formou-se em jornalismo na PUC de São Paulo, em 1983. Primeiramente, trabalhou nas revistas Istoé, Afinal e Veja. Depois, foi repórter especial e editor no Estado de S. Paulo. Ainda nos anos 80 , teve sua primeira experiência em telejornalismo, na tevê Cultura de São Paulo. A primeira função que ocupou na emissora foi de chefia de redação da produção. Logo de início, trouxe para a tevê Cultura o conceito de redação aberta, que havia sido implantada, com sucesso, no O Estado de S. Paulo:

A primeira providência foi derrubar todas aquelas divisórias, todas aquelas paredes, estabelecer uma nova forma de trabalho dentro da redação, onde você tinha, bem claras, duas editorias muito evidentes, para todo mundo trabalhar, que eram a chefia de reportagem, que cuidava do dia e a pauta e produção, que cuidava do dia seguinte. (NASCIMENTO, 2006)

\footnotetext{
${ }^{54}$ Entrevista gravada em São Paulo, em 07 de novembro de 2006.
} 
Com a divisão em duas áreas distintas, a chefia de reportagem incluía a apuração, a escuta e a reportagem, já a pauta preparava o dia seguinte, sem contar uma terceira etapa, que contemplava a edição e exibição do telejornal. Com o tempo, Nascimento foi assumindo outras funções, como chefia do departamento de jornalismo, onde era responsável por oito programas (60 Minutos, Jornal da Cultura, Opinião Nacional, Repórter Eco, Roda Viva, Grandes Momentos do Esporte, e Cartão Verde), além do departamento de documentários. Uma das grandes conquistas foi a criação do programa Repórter Eco, que estreou durante a Eco 92 e depois tornou-se um programa semanal, especializado em meio ambiente. Aos 29 anos, Nascimento assumiu a direção de jornalismo da emissora, onde ficou por nove anos. Depois, foi convidado assumir a chefia de redação da tevê Globo, em São Paulo. Nesta emissora, aprendeu o rigor jornalístico, na exibição de notícias com o diretor de jornalismo Evandro Carlos de Andrade, que acompanhava todos os passos do principal telejornal da casa, o JN. "Ele ficava no meu encalço, porque, às vezes, eu dava plantão no Rio de Janeiro, fechando o Jornal Nacional e ele sempre ligava pra saber o que seria colocado no ar e por quê?", relatou Nascimento. Atualmente, Nascimento é diretor de jornalismo da tevê Gazeta de São Paulo.

A jornalista Carmen Lúcia Amorin Ferraz Mendes ${ }^{55}$ começou a carreira nesta época rica, que foram os anos 80. Formada em Comunicação Social, pela Universidade Federal de Juiz de Fora, num curso considerado polivalente, pois permitia ao profissional atuar em rádio, tevê, relações públicas, publicidade e jornalismo. Antes de ingressar na televisão, Amorin teve uma passagem de 4 anos pelo impresso, no Diário Mercantil - um jornal de Juiz de Fora, que fazia parte dos Diários Associados.

Para ser repórter naquela época, conforme declarou Amorin, era preciso "ter um rostinho razoavelmente apresentável, uma boa dicção e tinha que ter um texto, também, bom." Além disso, não podemos esquecer que a época ainda era de muita improvisação, o que exigia certo jogo de cintura para transmitir a informação. "Então, o que se exigia pra trabalhar na tevê era ter boa aparência, chegar à frente da televisão e dar o seu recado, de uma forma

${ }^{55}$ Entrevista gravada em São Paulo, em 03 de setembro de 2007. 
simples e rápida" conclui Amorin. Essas características, para quem já trabalhava em jornal, eram fáceis. Era necessário vencer a barreira da timidez, para poder trabalhar como repórter ou trabalhar nos bastidores como pauteiro, ou editor de texto. O aprendizado, no dia-a-dia do telejornalismo, ainda era feito dentro das próprias redações, aconteceu com a repórter Carmen Amorin. Ela relata que, mesmo tendo feito o curso de Comunicação Social, na Universidade Federal de Juiz de Fora, que era muito conceituada na época, não existiam câmeras de tevê e nem estúdio na faculdade. O jeito que teve foi ela treinar com a apresentadora da emissora em que foi trabalhar. "Todos os dias, a locutora pegava um texto que um dos repórteres havia feito e treinava a minha dicção, porque eu não tinha dicção própria para tevê. Eu falava arrastado, um pouco lento, então, fazia esse treinamento." A evolução tecnológica ocorrida nos mais de 27 anos em que Amorin é repórter de televisão, foi observada por ela, a partir da utilização da fita Umatic:

Mudou completamente a maneira de fazer televisão, porque, primeiro, você tinha aquela fita enorme, que era a fita Umatic. Passou pra Betha e depois para a mini-DV. Hoje você tem tudo digitalizado, quer dizer a qualidade da imagem é uma coisa fantástica, e em termos de tecnologia, é um avanço incrível (AMORIN, 2007).

Como profissional de jornalismo, hoje ela consegue perceber o crescimento profissional que alcançou:

Acho que cresci nesta parte de questionar a ética do jornalismo. Qual é a função da notícia? Pra quem? Com quem eu tô conversando? Qual é o recado que eu quero passar? Isso mudou o meu profissional totalmente, a visão do jornalismo (AMORIN, 2007).

A principal mudança que ela observou, nesse período, foi relativa às entradas ao vivo. "Antes, a gente fazia muito stand-up, agora, ninguém mais me pede para fazer stand-ups. Ou você faz ao vivo ou faz matéria completa". Nesse tempo, todo de telejornalismo, Amorin sempre fez questão de trabalhar como repórter:

Eu gosto de ir pra rua, de ficar na rua, de conversar com as pessoas. Eu posso estar saindo de casa, no maior mau humor, com preguiça e tal, mas na hora que eu começo a conversar comum, com um outro, eu me transformo, assim, completamente, porque eu vou à casa de uma pessoa, entro na casa de outra, pessoas das mais variadas classes sociais e dos mais variados discursos. Então, cada um tem a sua preocupação, seu mundo, e aí a hora que eu vou entrando nesse mundo é uma aula, como se eu estivesse ganhando um presente. (AMORIN, 2007). 
Algumas emissoras já começavam a preparar e treinar melhor os seus profissionais, através de cursos internos e de manuais de redação, como fez a tevê Globo, em 1984, lançando o Manual de Telejornalismo. A primeira edição deste manual ficou restrita aos setores internos da redação, como uma relíquia, mas, aos poucos, esse conhecimento foi sendo difundido aos profissionais que entravam e que saíam da emissora, e, ao saírem, levavam-no e o copiavam em outras emissoras, também. O Manual editado em 1988, pela Central Globo de Jornalismo, é dividido em duas partes. A primeira, composta por Normas de redação, onde se destaca o repórter e a reportagem, as medidas para facilitar a edição, como bater a página e marcar o script, como e quando usar o gerador de caracteres, algumas recomendações práticas, palavras e expressões a evitar e alguns conselhos para a pronúncia brasileira das palavras. Na segunda parte, o tema central tratado é a Imagem, com uma breve introdução ao tema, a filmagem de entrevistas e algumas normas práticas para cinegrafistas e repórteres.
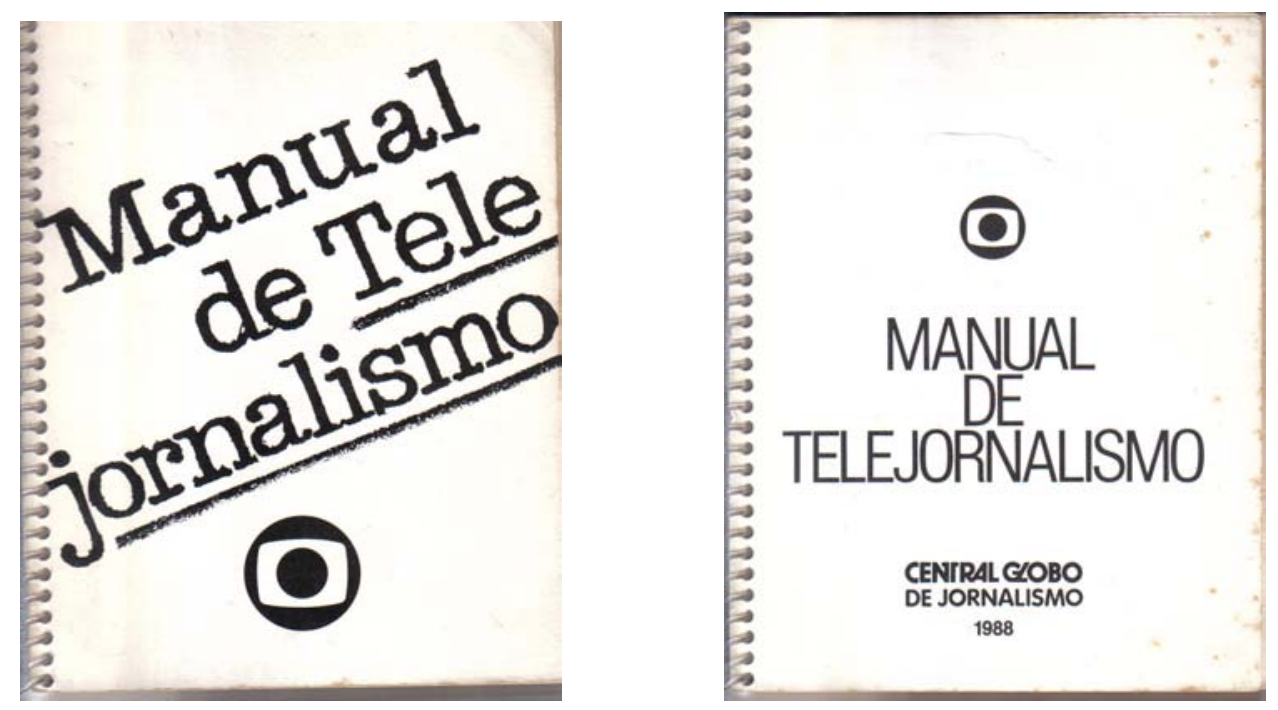

A capa e a primeira página do manual, que era distribuído para os novos telejornalistas

Ainda nos anos 80, começaram a se desenvolver os cursos de Comunicação Social e, logo em seguida, uma habilitação específica para jornalista, no lugar do curso polivalente, que havia sido anteriormente se transformado em comunicação social. 
Neste período, o Jornal Nacional passou por alguns problemas, que acabaram arranhando a sua boa imagem institucional. Um dos jornalistas que estava a frente do telejornal, em boa parte desta fase, foi Fabbio Peres. Sobre a experiência de ter ficado 6 anos (de 1984 até 1990) frente ao telejornal de maior prestígio da televisão brasileira - o Jornal Nacional - Peres diz que "a barra era bem pesada", porque o país estava saindo de uma ditadura que havia durado mais de 20 anos. A estrutura era diferente do que se tem hoje:

O Jornal Nacional tinha um editor-chefe e os editores que acompanhavam aquilo, à distância. Hoje o editor do Jornal Nacional tem editores que ficam na redação etc. Então, não é que a responsabilidade era maior, mas o nível e quantidade de decisões que você tinha que tomar era maior (PERES, 2006).

Para Peres, os jornalistas tiveram que reaprender a trabalhar, pois haviam passado por muitas situações de censura e, agora, a coisa tinha que tomar um rumo novo:

Nós fizemos toda essa transição com bastante cuidado, para não despertar suscetibilidade, principalmente porque a gente queria mostrar que o país tava maduro pra ser democrático. Então, todo o nosso esforço era para mostrar que, justamente essa redemocratização, era possível, que o jornalismo era responsável, pra não ficar dando maiores problemas (PERES, 2006).

Com relação ao episódio da edição do debate entre Lula e Collor, em 89, Peres foi lacônico ao dizer que esse caso já foi bastante debatido e afirma não ter acompanhado muito, porque, na época, o editor de política era o Ronald de Carvalho:

Eu não tenho uma opinião muito convicta, porque eu não assisti o debate, porque eu estava realmente ocupado na preparação do jornal, mas, enfim, o assunto já foi esgotado de várias formas. Acho que a eleição já tava decidida. Aquele debate pode ter tido uma influência. Eu realmente não tenho, assim, um ponto de vista muito firmado a respeito do debate, até porque não assisti (PERES, 2006).

O fato é que, mesmo o caso já tendo sido amplamente discutido por vários autores, como Mário Sérgio Conti, no seu Notícias do Planalto, a revista Imprensa, em várias edições, e a própria emissora, na sua publicação de Memória Globo Jornal Nacional - A notícia faz história, entre outros, é preciso, no caso desta pesquisa, fazer também um registro, não para buscar culpados, mas, porque faz parte da história do telejornalista brasileiro. 
Alfredo Eurico Vizeu Pereira Júnior ${ }^{56}$, que atualmente se dedica ao ensino e à pesquisa em telejornalismo, também iniciou a carreira em emissoras de televisão, nos anos 80. A primeira experiência dele foi em Porto Alegre, no Rio Grande do Sul, na TV Difusora, que depois passou a retransmitir a tevê Bandeirantes. Para ele, a exigência, ou melhor, o que o habilitou ao trabalho foi estar se formando em jornalismo e aprender na prática. "Exigia-se que se tivesse noções básicas de jornalismo, não tinha muita preocupação, não havia uma exigência que se tivesse qualificado para trabalhar". Então, aquela primeira experiência foi a base para Vizeu. "Comecei a trabalhar na Bandeirantes, como uma espécie de escola. Naquele período, naquela virada $79 / 80$, você ainda tinha essa possibilidade". Durante sua carreira na Bandeirantes, começou como produtor e chegou a diretor de jornalismo, passando por quase todas as funções dentro da emissora. Em paralelo, também trabalhou na tevê Guaíba, como chefe de reportagem e produtor do programa Espaço Aberto - um programa de debates. Depois, teve uma passagem pelo jornalismo impresso no jornal Zero Hora, e, mais adiante, foi para o Rio de Janeiro, onde trabalhou nas tevês Manchete e Bandeirantes. Na primeira, foi editor internacional e, depois, de economia. Uma experiência interessante, neste período, foi a criação do Jornal da Manchete segunda Edição. "Um jornal interessante, porque teve uma série de experiências, uma série de trabalhos desenvolvidos ali e depois aproveitados pelo Bom Dia Brasil (da tevê Globo). Uma delas foi a prática daquela tela ao fundo do cenário". Com o passar dos anos e com o exercício da profissão, Vizeu começou a repensar a sua atividade jornalística em televisão. "Pesquisar sobre ela, o que ela representa, o que faz jornalismo no Brasil? Fiz mestrado na PUC, do Rio Grande do Sul". Desta pesquisa realizada durante o mestrado, surgiu o livro Decidindo o que é notícia - os bastidores do telejornalismo "Fui investigar o que influencia o jornalista na hora de decidir o que é e o que não é notícia". Ele mostrou como as práticas e as rotinas não são mecânicas para 0 jornalista, apoiando sua pesquisa na teoria do news making. Depois, partiu para o doutorado, para investigar como é o público para os telejornalistas.

${ }^{56}$ Entrevista gravada em Brasília, em 9 de setembro de 2006. 
Sobre como é que a audiência significava textos, reportava no processo, que virou a hipótese da audiência presumida, que foi o que eu procurei pesquisar. Como é que o jornalista, o seu processo e práticas culturais a medida da expressão das empresas..." (VIZEU, 2006).

Através do acompanhamento de dois telejornais do Espírito Santo, um da Globo e outro do SBT, ele buscou descobrir como é que o público está presente nas notícias, dando origem à sua segunda publicação, $O$ lado oculto do telejornalismo.
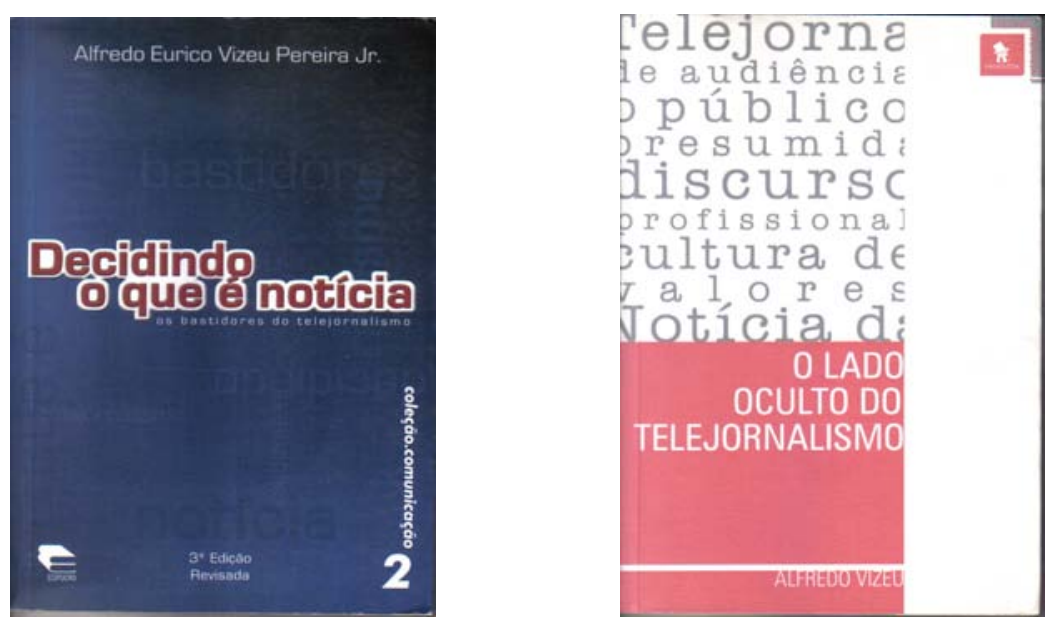

As duas publicações de Vizeu, a dissertação de mestrado e a tese de doutorado.

O jornalista Cláudio Barcelos de Barcellos ${ }^{57}$, mais conhecido como Caco Barcellos, foi um dos que, nos anos 80 , também se enveredou para a televisão. Formado em jornalismo, pela Universidade Católica do Rio Grande do Sul - a PUC de Porto Alegre, iniciou a carreira, antes mesmo de terminar a faculdade, trabalhando em veículos impressos. Começando pela Folha da Manhã, do grupo Caldas Júnior, de Porto Alegre, e seguindo a carreira, atuando nas revistas Veja, Istoé, TV Guia e Senhor, em jornais como Opinião, Pasquim, Movimento e Jornal da Tarde e, ainda, na Editora Abril. Também teve uma fase, que ele mesmo chama de "jornalista itinerante." "Saía atrás de uma história que achava interessante, parava pra me envolver nela, depois, pra escrevê-la, e depois, pra oferecer pros veículos da grande imprensa. Eu era independente, cinco anos assim." O primeiro convite para ir para a televisão veio de um de seus compradores freqüentes de matérias - Luiz Fernando

${ }^{57}$ Entrevista gravada em Fortaleza, em 20 de maio de 2008. 
Mercadante, por volta de 1976. Mas como ainda estava apaixonado pela vida itinerante, não aceitou. "Eu achava a televisão muito oficialista, muito pouco envolvida com reportagem." Tempos depois foi morar nos Estados Unidos e lá passou a ter outra visão da televisão "Eu comecei a perceber as produções maravilhosas de documentários de tevê. Eu fiquei apaixonado pelos documentários e pela televisão." Foi só no início dos anos 80, que Caco conseguiu trabalhar na televisão, depois de fazer testes e mostrar o seu potencial para o veículo. "Eles viram em mim a possibilidade de fazer pela primeira vez, talvez, eu não me lembro de fazerem antes, um jornalismo investigativo, com consciência, pela natureza do veículo que não combinava muito." A adaptação dele com a televisão também contou com a ajuda das fonoaudiólogas:

\begin{abstract}
Eu sempre me dediquei a ter aulas com as fonoaudiólogas. Até hoje, me ajudam bastante. $E$ acho que é um trabalho permanente. Você precisa sempre fazer exercícios para melhorar a dicção e empostar melhor a voz. E o maravilhoso é que os conselhos que essas fonoaudiólogas dão, te ajudam a falar de maneira coloquial, com mais clareza. Você passa ser você mesmo, porém, com mais cuidado, fazer com que todo mundo te ouça corretamente. Coisa simples, muito simples, mas é muito complicado ser simples (BARCELLOS, 2008).
\end{abstract}

Mas, num primeiro momento, a sua passagem pela tevê Globo não o possibilitou de desenvolver todo o seu potencial investigativo, adaptado ao veículo televisão, pois se ausentou da emissora por um período de um ano, quando foi participar do projeto da tevê Abril. No final de um ano, como a concessão para a Editora Abril não se concretizou, o projeto que mobilizava cerca de 150 jornalistas foi desativado. Assim, Barcellos voltou para a Globo e só ali pôde dar continuidade ao seu projeto de jornalismo investigativo na tevê. "No investigativo, se você estiver cobrindo um fato que envolva a denúncia contra a honra de alguém, ou um elogio a alguém, eu acho que você tem que ter postura ativa de apuração, com luz própria independente." Na televisão, as denúncias praticamente não existiam naquele momento, então a grande novidade trazida por Barcellos foi fazer investigação, com denúncia. A primeira dificuldade, no começo, foi trabalhar com o equipamento de tevê em jornalismo investigativo:

As equipes eram imensas, na época eram cinco que formavam uma equipe de tevê. Então, pra chegar discreto, pra investigar com aquele batalhão, equipamento imenso, a câmera amarrada na máquina de 
som, com cabo, quilômetros de cabos espalhados pra todo lugar. Aí você dribla toda a dificuldade, quando você tem vontade de apurar com rigor e independência (BARCELLOS, 2008).

Em estudo realizado por esta pesquisadora ${ }^{58}$, foi possível confirmar que, no dia 03 de fevereiro de 1980, acabou oficialmente a censura ao telejornalismo. Esse fato fez esta década se transformar no período de maior ebulição e criatividade na televisão brasileira, pois o país estava saindo de uma ditadura militar de mais de 20 anos e precisava mostrar, através das imagens da televisão, o que era a liberdade de expressão. Havia também a necessidade de falar e de mostrar o que, até então, era censurado pelos militares. O telejornalismo era conhecido como "chapa branca", pois só podia mostrar e falar aquilo que era de interesse do governo. Havia o consenso de que, pela televisão, o país vivia numa "ilha de tranquilidade", pois eram essas as notícias que os telejornais mostravam. O recorte feito a respeito dos anos 80 , identificou a chegada de jornalistas oriundos de veículos impressos, para trabalhar na televisão. $O$ fenômeno ocorreu porque a televisão, em termos de jornalismo, se apresentava inexpressiva, até então, ou como se costumava dizer, fazia-se de porta voz do governo militar. Não havia grandes furos descobertos pelos telejornais. O fluxo de informação era sempre iniciado pelos jornais impressos e, nunca, pela televisão. Neste período específico, é possível identificar e caracterizar dois momentos significativos do telejornalismo brasileiro, que podem ser definidos como iniciais para o jornalismo investigativo na televisão: a chegada do jornalista Caco Barcellos na tevê Globo; e a criação do programa Documento Especial, da tevê Manchete.Dentre as inúmeras reportagens investigativas produzidas por Barcellos, na Globo, para os mais diversos telejornais (Jornal Nacional, Hoje, Globo Repórter, Fantástico e Profissão Repórter), uma delas foi destaque e recebeu o prêmio Vladimir Herzog, sobre o atentado militar, durante a ditadura, denominada Riocentro 15 anos depois. Com a evolução tecnológica o trabalho para Barcellos ficou muito mais fácil. "Como eu gosto de ir muito além da entrevista, acho importante provar que uma entrevista é verdadeira, e com a democracia do acesso ao equipamento, hoje é possível." Uma outra novidade da tecnologia é o surgimento do jornalista

\footnotetext{
${ }^{58}$ O jornalismo investigativo na televisão brasileira - trabalho apresentado no XXXI Congresso Brasileiro de Ciências da Comunicação - Intercom 2008, em Natal no RN, no GT de Jornalismo.
} 
que opera câmeras, edita em ilhas não-lineares, enfim, executa quase todo o processo da reportagem. Para Barcellos esse processo é inevitável:

\begin{abstract}
Está tudo tão simples, tão fácil, que acho que não vai gerar falta de possibilidades no mercado. Porque, se de um lado você, quando filma, está sendo menos repórter, de outro, também, você está sendo mais cinegrafista. Pode ser mais editor, mais tudo. Eu acho que todos nós precisamos aprender a nos habituar para outros equipamentos (BARCELLOS, 2008).
\end{abstract}

Atualmente, ele coordena uma equipe de jovens repórteres que se revezam nas funções, no programa Profissão Repórter.

Uma das marcas registradas dos anos 80 é chegada de duas novas redes ao mercado televisivo brasileiro: a rede Manchete e o SBT. A Manchete, do Rio de Janeiro, contou com a presença, desde o início, do jornalista Nelson Hoineff ${ }^{59}$, que veio originariamente do impresso, tendo passado por jornais como O Jornal, Diário de Notícias, Última Hora, O Globo e revistas como Veja e O Cruzeiro. Segundo ele, foi entrando como todo mundo que estava lá, vindo de jornal. "Eu era editor de cultura e a gente foi aprendendo ali, na prática mesmo." O primeiro Jornal da Manchete era longo, tinha 1 hora e meia de duração, dividido em editorias de esporte, internacional, cultura, política e cidade. "Logo depois, percebeu-se que seria melhor deixar o telejornal com uma hora e criar um programa de cultura antes". Foi então, que Hoineff passou a dirigir um programa de cultura chamado, Panorama. Também dirigiu o Jornal da Manchete Segunda Edição, que entrava no ar às 11 da noite. Depois de um tempo e devido à divergências, Hoineff deixou o jornalismo e foi cuidar do Núcleo de Projetos Especiais, onde criou o programa Documento Especial "Eu fui colocando no papel umas regras que a gente tinha que seguir, umas coisas que a gente não pode mostrar, coisas que são proibidas, e decidi apresentar um programa com tudo isso." O programa estreou em agosto de 1989, às quartas-feiras, às 11 da noite, um horário em que a audiência era traço ou um ponto. "Na primeira semana, fez 7 pontos, na segunda, fez 8, e na terceira, fez 13 pontos, configurado como maior sucesso da Manchete." Com isso, o programa passou de meia para uma hora de duração e, também, mudou para a

\footnotetext{
${ }^{59}$ Entrevista gravada no Rio de Janeiro em 20 de novembro de 2006.
} 
sexta-feira, a sua exibição. Alguns temas polêmicos eram tratados pelo Documento Especial, como prostituição, travestis e religiões:

Havia dois Brasis, o Brasil que tava na televisão e o Brasil que tava diante dos seus olhos. Então, você olhava para os lados e via pobreza, bandidagem, roubo, miséria, sexo, corrupção e você ligava a televisão e não via nada disso. O Documento introduziu todos esses temas (HOINEFF, 2006).

Houve também uma inovação da linguagem da televisão, com relação ao tempo de duração de cada plano. "Planos em televisão tem que ter 2 ou 3 segundos, estourando, mais de 4 segundos tem que cortar. Nós começamos a fazer planos seqüência de 30 segundos, um minuto, dois minutos e até quatro minutos". O retorno dessa experiência era a reação da audiência, que não rejeitava essa novidade.

Certa vez no programa sobre a Igreja Universal do Reino de Deus havia uma menina em transe no Maracanã e depois de tentar editar uma meia dúzia de vezes, ficou muito claro que aquele transe não podia durar três segundos, não podia durar trinta segundos. Aquele transe, só existia, se durasse o tempo do transe, que era de quatro minutos e meio (HOINEFF, 2006).

Outras novidades implementadas pelo Documento Especial foram a retirada do repórter e do insert. "Não havia insert - que é uma coisa de extremo posicionamento ético na televisão, quer dizer, você corta a fala do entrevistado, com um plano de um repórter escrevendo num caderninho, e, também, não havia nenhum elemento interferente, não havia repórter". O Documento Especial ficou no ar pela Manchete até 1992, depois transferiu-se para o SBT, onde ficou uns três ou quatro anos e teve sua última versão pela tevê Bandeirantes, através de uma produção independente.

Amauri Sérgio Soares ${ }^{60}$ foi um dos primeiros talentos recém saídos de uma universidade que teve uma carreira brilhante, sempre dentro da televisão. Em 1987, antes de terminar o curso de Comunicação Social - habilitação em Jornalismo, na Unesp de Bauru, ele já estava estagiando na tevê Globo Oeste Paulista, da mesma cidade. Foi trabalhar em televisão, devido ao fascínio que o veículo exercia nele e, também, por gostar de escrever. "Teve um momento bem simbólico, que foi um concurso de redação que eu venci na escola. $E$ isso me incentivou muito, me inspirou muito, mais eu gostava de escrever, gostava

\footnotetext{
${ }^{60}$ Entrevista gravada no Rio de Janeiro, em 16 de junho de 2008.
} 
de televisão, e, por isso, procurei trabalhar em televisão." Antes mesmo de terminar o estágio, como editor de texto, foi convocado para cobrir uma licença maternidade de uma jornalista da redação, e, em seguida, foi contratado. Ele relata que no seu caso não havia necessidade de nenhum tipo de experiência anterior, porque os jornalistas que estavam trabalhando naquele momento já eram profissionais, mas não tinham formação acadêmica, e por isso estavam fazendo a faculdade junto com ele:

Então, a minha classe na faculdade foi uma classe muito atípica, porque metade da classe era formada por profissionais, que tinham experiência, trabalhavam na tevê Globo, estavam no mercado e voltaram pra universidade, porque precisavam do diploma (SOARES, 2008).

O convite para o estágio partiu dos próprios colegas de classe. Soares continuou como editor de texto e, com o tempo, teve que experimentar outras atividades, como reportagem e apresentação do programa, pois a emissora, naquele momento, incentivava os jornalistas a atuar em mais de uma função. "Eu comecei a fazer reportagem, mas eu nunca gostei. Eu ia pra rua, fazia algumas reportagens, voltava e nunca gostei da experiência de me ver no vídeo, eu gostava mesmo é de trabalhar na edição." Na apresentação, chegou a apresentar uma agenda cultural no SPTV, aos sábados, e, também, um programa de entrevista, de domingo pela manhã, chamado A Palavra é Sua. Mas, segundo ele, foram experiências passageiras. "O que ficou mesmo foi a edição, que é o que eu gostava e que eu preferia." Tanto, que em pouco tempo, se tornou o editor-chefe do SPTV, em Bauru e, na seqüência, chefe de redação. Depois, por volta de outubro de 1989, foi convidado para ser editorexecutivo do Bom Dia São Paulo e teve que se mudar para São Paulo. No ano seguinte, recebeu um convite do jornalista Carlos Nascimento para ser editorexecutivo do um projeto novo, chamado São Paulo Já61. No ano seguinte, resolveu sair da tevê Globo, devido a um desentendimento com a chefia. $\mathrm{Na}$ seqüência, foi convidado por Lílian White Fibe para ser editor-executivo do Jornal do SBT, que deveria estrear, por ela, na emissora. O SBT estava implantando um grande projeto de jornalismo e Soares acabou assumindo

\footnotetext{
${ }^{61}$ São Paulo Já foi um telejornal que mudou a configuração do horário da tevê Globo no estado de São Paulo, porque expandia muito o espaço para o noticiário estadual e deixava de exibir o Jornal Hoje.
} 
como editor executivo do telejornal Aqui Agora. 62 "O projeto do Aqui Agora foi muito interessante, porque eu vi ali, uma oportunidade muito promissora de mudança, de mexida nos formatos dos telejornais brasileiros." A experiência, apesar de nova, durou apenas 5 meses para Soares, pois o grande projeto de conteúdo que ele havia vislumbrado foi deixado de lado. "Eu achei que o formato seria a grande ferramenta de reformulação de conteúdo, porque trazia cobertura de direito do aposentado, a questão dos reajustes de aposentadoria, era uma época de inflação alta, direito do consumidor." Para ele, o sucesso viria pelo conteúdo e pela novidade do formato, e com substituição de "pessoas famosas" (Maguila, Gil Gomes, Wagner Montes, Jacinto Figueira) pela contratação de jornalistas. Mas o sucesso foi tão grande, que o SBT entendeu que não tinha necessidade de fazer as mudanças. "Pra mim era muito claro que aquela audiência era uma audiência de curiosidade, que iria se dissipar se a gente não tivesse realmente um conteúdo pra oferecer." A avaliação que Soares faz hoje sobre esse episódio é que havia, ali, uma oportunidade extraordinária de se usar uma linguagem nova, para tratar de uma situação latente. "Eu acho que se aquele projeto tivesse tido outro caminho, a história teria sido outra, inclusive, daquela emissora." Para ele, a tese de que o caminho para mostrar as mazelas do país deveria se dar, primeiro, no noticiário policial nunca o convenceu. "O Aqui Agora foi vitima do sucesso que fez, porque ele fez um sucesso extraordinário nas primeiras semanas, depois de dois ou três meses, estava com uma audiência inimaginável pro SBT, naquele horário." Outra proposta que nunca convenceu Soares é de que um telejornal popular não precisava ser popularesco. "Ele tinha um papel importante a ser desempenhado". Depois da sua rápida passagem pelo SBT, Soares voltou para a tevê Globo, mas para trabalhar no Fantástico. "O meu papel era trabalhar com as reportagens, com as pautas, a edição, a linguagem e tal, que é uma coisa que eu sempre gostei muito." Depois de trabalhar por um período no Rio de Janeiro, voltou para São Paulo, para estruturar o núcleo do Fantástico. Na seqüência, resolveu sair da emissora para trabalhar em campanha. Ficou 6 meses fora e retornou, em 1993, à emissora, em São

${ }^{62}$ Aqui Agora foi um novo formato de telejornal inspirado num modelo argentino, com um formato muito mais solto, câmera na mão, as pessoas falando e abordando temas que normalmente o telejornalismo, naquele momento, não abordava como: aposentadoria, direitos do consumidor, entre outros. 
Paulo, para ser o editor executivo do Jornal da Globo, que naquele momento, estava sendo transferido para a capital paulista. Foi aí que fez dobradinha com Lílian White Fibe. "Nós implantamos um novo telejornal de rede, em São Paulo. E foi um momento muito interessante, porque até aquele momento, São Paulo não tinha nenhum jornal de rede. Foi o primeiro." Em 94, quando teve a Copa do Mundo, nos Estados Unidos, Soares ficou 2 meses trabalhando na preparação e na cobertura do evento. $\mathrm{Na}$ volta, assumiu a chefia de reportagem da Globo de São Paulo. Em 95, quando havia recebido um convite do jornalista Roberto Cabrini para implantar o núcleo de jornalismo do SBT, em Nova lorque, também recebeu uma proposta da direção de jornalismo (Alberico Souza Cruz) da Globo para trabalhar em Nova lorque, junto com o jornalista Paulo Henrique Amorin. Antes mesmo de concluir os preparativos para mudar para Nova lorque, trabalhando para a tevê Globo, uma mudança na direção de jornalismo da emissora altera novamente os planos de Soares. Quando assume o comando do jornalismo da Globo, o jornalista Evandro Carlos de Andrade promove uma grande mudança em todo o primeiro time da emissora. Soares é convocado para uma reunião, onde Andrade afirma querer honrar todos os compromissos assumidos pelo seu antecessor. Soares deixa claro que não há necessidade de manter a proposta, pois não fazia sentido uma vez ele deveria ter liberdade de trabalho. "A reação dele foi surpreendente, porque ele disse que 'era exatamente isso que queria saber, porque ele tinha outros planos para mim. Eu quero que você venha pro Rio de Janeiro, para o Jornal Nacional. Eu levei um susto." Mas, aos poucos, Soares foi se acostumando com o novo comando da emissora, que, às 3 horas da tarde pediu que ele descesse para a redação do $\mathrm{JN}$ e fechasse o telejornal daquela noite. Ele ficou um ano e pouco no JN, mas foi um momento de muitas mudanças, pois, sob o seu comando, houve a troca dos apresentadores por jornalistas. "Nós aposentamos os apresentadores e introduzimos o âncora no JN. Havia todo um projeto de reformulação editorial e tudo." A questão da mudança do formato foi uma atitude, segundo ele, madura da direção da emissora. "Nós já estávamos maduros pra ter âncoras na apresentação, ter jornalistas na apresentação e não locutores. Então, a primeira substituição foi a do Sérgio Chapelin pela Lílian White Fibe. Ficaram Cid Moreira e Lílian White Fibe." Depois, com o passar do tempo, o apresentador Cid Moreira foi substituído pelo jornalista 
Willian Bonner ${ }^{63}$. Depois de participar de parte da história do JN, Soares foi convocado para voltar a São Paulo e assumir a direção de jornalismo da Globo São Paulo. "Foi o momento de fazer o projeto mais amplo, mais consistente, mais abrangente, que eu fiz aqui na tevê Globo no jornalismo." Ele reformulou a estrutura de jornalismo de São Paulo, que contou com a construção da nova sede, e implantou um projeto de jornalismo comunitário no Estado. Para que esse projeto fosse executado, o primeiro passo foi preparar todas as emissoras do interior de São Paulo para que elas pudessem, isoladamente, fazer jornalismo comunitário em suas áreas de cobertura. "Elas dependiam de São Paulo, que produzia $30,40,50 \%$ do telejornal do estado, ou seja, elas vazavam, como a gente diz, blocos de jornalismo produzidos em São Paulo." Essa preparação das emissoras do interior contou com a formação da redação, contratação de profissionais, treinamento e compra de equipamento. Quando as emissoras do interior ficaram independentes da capital e puderam fazer o seu próprio jornalismo comunitário, a etapa seguinte de Soares foi a implantação de um projeto de jornalismo comunitário voltado para a região metropolitana de São Paulo.

Foi um projeto incrível, que eu gosto muito, que provocou mudanças profundas no nosso jornalismo e na nossa linguagem (...) nós nos propusemos a efetivamente discutir e refletir a região metropolitana de São Paulo (...) nós nos propusemos a rever os formatos, as limitações, as amarras de linguagem, de formato, técnicas e tecnológicas. Assim, pra gente fazer um jornal mais vivo um jornal mais humanizado, mais informal, capaz de se adaptar ao noticiário do dia, não tão engessado (SOARES, 2008).

Este novo projeto, implantado por Soares em São Paulo, aconteceu exatamente no momento em que a tevê Globo, devido à crise financeira que enfrentava, resolveu vender as emissoras próprias afiliadas do interior do estado e dar maior liberdade editorial regional para cada uma delas, pois havia tornado-se impossível manter uma estrutura tão grande.

Em 2002, ao finalizar todo o projeto, Soares recebeu um convite da emissora para sair do jornalismo e ir para Nova lorque, "mais do que ir para Nova lorque, o importante era sair do jornalismo, que era algo que estava nos

\footnotetext{
${ }^{63} \mathrm{O}$ site da emissora informa que a mudança ocorreu em 01 de abril de 1996 e que a alteração foi simultânea, ou seja, saíram da bancada Cida Moreira e Sérgio Chapelin e deram lugar para Willian Bonner e Lílian White Fibe. (http://video.globo.com/Videos/Player/Noticias/.html- acesso em 30 de agosto de 2008).
} 
meus planos fazia algum tempo." Nesta fase, Soares desenvolveu projetos em televisão, como a implantação da nova sede da emissora em Nova lorque, entre outros. Depois de 5 anos, voltou ao Brasil, no final de 2007, onde dirige o departamento de projetos especiais.

Soares sempre foi um profissional de visão, acima de tudo. Durante o período em que foi diretor de jornalismo da tevê Globo de São Paulo, pude acompanhar um fato inédito na história do telejornalismo brasileiro. O fato foi estudado por esta pesquisadora como o Caso Covas ${ }^{64}$, pois tratou-se da quebra de um padrão formal, na rotina de um telejornal. O fato histórico acorreu no dia primeiro de junho de 2000, quando o então governador de São Paulo, Mário Covas, foi até a Praça da República, em São Paulo, onde os professores grevistas encontravam-se acampados, desde 12 de maio. Este fato derrubou a edição inteira do SPTV Segunda Edição (telejornal regional da TV Globo na grande São Paulo). Os fatores e os critérios hierárquicos e decisórios, que levaram a este inusitado momento do telejornalismo brasileiro foram parte integrante das buscas do estudo. O jornalista Soares foi o arquiteto desta inovação apresentada pelo telejornal.

Para concluir esta seção, algumas comparações entre os anos 70 e 80 são necessárias, para podermos acompanhar como ocorreu o processo evolutivo de formação do telejornalista brasileiro, neste período.

Os anos 70 foram marcados por uma avalanche de novas tecnologias agregadas ao processo de produção dos telejornais, como a unidade portátil de jornalismo, o filme colorido, o teleprompter (mesmo que artesanal ainda) e o cromaqui. Mesmo com a utilização precária, estas tecnologias foram sendo introduzidas no cotidiano dos telejornalistas. A formação acadêmica, apesar de já existir o curso de Comunicação Social, ainda não era uma exigência para o mercado profissional. Nos anos 80, houve o desenvolvimento e domínio completo das tecnologias introduzidas na década anterior. A chegada do formato Umatic e do link foi o grande diferencial tecnológico da década. As equipes de reportagem que trabalhavam nos anos 70 eram constituídas por cinco integrantes, já, nos 80 , foi reduzida para três ou dois integrantes, devido

${ }^{64}$ O Critério de Noticiabilidade do SPTV $2^{\text {a }}$ edição no caso Covas - trabalho apresentado ao NP 02 - Jornalismo, do V Encontro dos Núcleos de Pesquisa da Intercom, no XXVIII Congresso Brasileiro de Ciências da Comunicação, em 2005, no Rio de Janeiro. 
à compactação dos equipamentos. O diploma de jornalismo passou a ser exigência, o que levou muitos profissionais a voltarem aos bancos universitários e concluir a formação acadêmica, devido à regulamentação da profissão, ocorrida no final dos anos 70 .

O surgimento, nos anos 70, de alguns programas, como Globo Shell e o Globo Repórter e Bom Dia São Paulo contribuíram para o desenvolvimento da reportagem, com a participação de um grupo de cineastas. A época foi marcada por muita criatividade, mas houve problemas com a censura, que exigia o controle do conteúdo exibido pela televisão. Na década seguinte, os cineastas foram substituídos pela figura do repórter, o que caracterizou a mudança do trabalho autoral dos primeiros para o trabalho industrial coletivo dos segundos. Houve, também, a valorização dos programas de entrevistas e debates e introdução do jornalismo investigativo, através do trabalho dos jornalistas Caco Barcellos e Nelson Hoineff, entre outros.

Algumas normas básicas começaram a ser padronizadas dentro das redações, nos anos 70, mesmo com o aprendizado sendo desenvolvido nas atividades do dia-a-dia. Já nos anos 80 , com a chegada do Manual de Telejornalismo, o treinamento começou a ser sistematizado dentro das próprias redações, antes dos profissionais iniciarem suas atividades. Houve, também, a introdução da fonoaudiologia, para ajudar o telejornalista a posicionar melhor sua voz.

Um dos principais problemas enfrentados pelos telejornalistas na década de 70 foi a censura, que agia de forma dura e, por vezes cruel, como no caso ocorrido conforme o caso ocorrido com o jornalista Vladimir Herzog. Um dos resultados desse endurecimento foi a valorização do noticiário internacional e a criação da figura do correspondente internacional, como saída estratégica para poder fazer um trabalho com qualidade. Nos anos 80 , com o processo de redemocratização do país, a censura deixou de existir oficialmente, mas deixou marcas profundas na cultura das redações, estabelecendo a autocensura e a censura interna. Os telejornalistas tiveram que reaprender a conviver com a democracia.

Nas universidades, começaram a se formar os primeiros professores específicos para a disciplina, que, no início, denominou-se jornalismo audiovisual e, depois, telejornalismo. Desta fase, destaca-se o trabalho do 
jornalista Walter Sampaio, nos anos 70. Nos anos 80 , o número de professores e de dissertações de mestrado e teses de doutorado, direcionadas ao telejornalismo, cresceu em todo país e este passou a existir como novo campo de pesquisa. Cresceram, também, os cursos de Comunicação Social. A habilitação em Jornalismo se efetivou em todo país e não mais existiu o curso polivalente em Comunicação Social.

O modelo americano, que foi implantado nos anos 70 , com o sucesso do $J N$, nos anos 80 , se efetivou e foi copiado por todas as emissoras do país, como um padrão hegemônico. As novas emissoras que surgiram incorporaram o padrão, com pequenas alterações e adaptações, que já estavam em curso desde a implantação da televisão no Brasil.

\title{
2.3. terceira fase Internet e SBTV-T - década de 1990 até os dias atuais
}

\begin{abstract}
Não foi a televisão que entrou na casa das pessoas, mas sim a realidade. E o telejornalismo não inventou o mundo moderno, apenas dele faz um registro factual ou interpretações sensatas, capazes de ajudar o mundo da maneira que melhor convier (MELLO E SOUZA, 1982).
\end{abstract}

A implantação dos computadores nas redações de telejornalismo ocorreu nos anos 90. No caso da tevê Record de São Paulo, Cardim relata que houve certa resistência dos telejornalistas, comparável com a chegada da televisão: "quando veio a televisão, nossa!... vai acabar o jornal impresso, vai acabar o rádio, não! Foi se ajeitando, cada um ocupou o seu espaço, de forma útil para cada um." No caso da chegada dos computadores, ela diz que a máquina de escrever era uma coisa muito romântica, porque proporcionava aquela canção dedilhada por muitas mãos, e, no caso específico da televisão, era necessário fazer o texto todo em caixa alta. Na Record, em 1996, quando o bispo João Batista introduziu a informática, como haviam jornalistas que trabalhavam no impresso, onde o processo já era informatizado, houve certa insegurança, se aquilo iria funcionar ou não, e se não iria haver demissões, como houve nos jornais: "a máquina ficava ali de lado, porque, se faltasse luz, a nossa salvação estava ali." Demorou uns seis anos para a retirada total das máquinas de escrever da redação da Record. 
Antes de entrar propriamente nas questões que envolvem o profissional que está trabalhando, a partir dos anos 90, e do profissional que trabalhará quando o sistema de televisão aberto, no Brasil, estiver digitalizado (provavelmente até 2016), é importante conceituar o que deve ser o SBTV-T Sistema Brasileiro de TV. Estas políticas estruturais vão nortear todo o trabalho do telejornalista na era digital, devido à sua abrangência e especificidade.

Segundo Zuffo (2003), com a posse do Governo Lula, o país evoluiu de um estado de letargia e absoluta ausência de estratégia de governo, para uma situação de intensa vontade política, em relação à implantação da TV Digital Aberta no Brasil. No documento que o autor denominou de Modelo Brasileiro de TV Digital Aberta, estão contidas as ações abrangentes para a estruturação, democratização e implantação, baseadas no estabelecimento de um conjunto de políticas públicas estruturais de longo prazo.

É importante salientar que o sucesso dessa iniciativa, no Brasil, pode ter forte influência sobre $2 / 3$ da humanidade, que ainda não definiu suas políticas públicas de TV Digital, incluindo a totalidade dos países da América Latina. Ou, ao contrário do que Lima questionou a respeito Brasil ser o único país a usar o sistema japonês na América Latina: "Será que estamos realmente no caminho certo? Será que é mesmo impossível uma abertura ampla da TV Brasileira?" (2007:185). Pode ser essa a grande chance do país sair na frente e, ainda, obter vantagens e desenvolver novas tecnologias. Com isso, será possível a criação de oportunidades de exportação para outros países, com impacto na empregabilidade nas indústrias de conteúdo e de eletroeletrônicos, no Brasil. (ZUFFO, 2003)

Devido à complexidade da questão da TV Digital um primeiro esclarecimento que Zuffo faz é diferenciar Modelo, Sistema e Padrão de TV Digital.

O Modelo de TV Digital incorpora a visão de longo prazo e o conjunto de políticas públicas. O Modelo deve articular todas as iniciativas, atividades e ações relacionadas à questão. O Modelo define as condições de contorno para o estabelecimento do Sistema e respectiva definição do Padrão. O Sistema de TV Digital é o conjunto de toda infra-estrutura a atores (concessionárias, redes, produtoras, empresas de serviços, Ongs, indústrias de conteúdo e eletroeletrônicos). O Padrão de TV Digital é o conjunto de definições e especificações técnicas necessárias para a correta implementação do Sistema, a partir do Modelo definido (ZUFFO, 2003). 
Historicamente, a tevê analógica aberta no Brasil constitui-se num instrumento de integração nacional, porque consegue unir o país através de um veículo de comunicação, como era o sonho do regime militar, que governava o país na época do seu desenvolvimento estrutural (60 e 70). De acordo com o IBGE, mais de $90 \%$ dos brasileiros da área urbana têm acesso à tevê aberta. Isso totaliza cerca de 54 milhões de aparelhos no país. Sendo que o legado da tevê analógica é um verdadeiro capital nacional, contando com empresas nacionais, tecnologia nacional e conteúdo quase 100\% nacional (ZUFFO, 2003). De acordo com Lima, a TV aberta atinge, hoje em dia, mais de 170 milhões de brasileiros, e temos, ainda, as antenas parabólicas, que atingem 70 milhões de pessoas e a TV por assinatura ficou estagnada, nos nove milhões de espectadores (LIMA, 2007: 182).

Para os próximos anos, a expectativa é que haja a chamada convergência, declara Zuffo. Pois, segundo ele, na década de 90, a internet modificou radicalmente setores tradicionais da mídia como o jornalismo impresso, o mercado editorial e o mercado fonográfico. A convergência, através da tevê aberta, talvez seja a grande oportunidade do governo conseguir a inclusão social, através da inclusão digital, pois a televisão já faz parte da vida da grande maioria da população e o computador não. E não só para o Brasil, mas para $2 / 3$ da humanidade, não tem perspectivas entre os padrões da tevê digital existente, devido aos altos custos de utilização de patentes e de outros fatores de propriedade intelectual. (ZUFFO, 2003)

Atualmente, existem quatro padrões de tevê digital em desenvolvimento no mundo: o padrão ATSC-T (Advanced Television Systems Comittee) Norte Americano, o padrão DVB-T (Digital Video Broadcasting), que foi proposto por um consórcio de países europeus da Comissão Européia (conhecido como padrão europeu), O ISDB-T (Integrated System Digital Broadcast), fomentado por um consórcio amplo de empresas e concessionárias japonesas, denominado DiBEG, e o padrão Chinês, que utiliza muito dos conceitos incorporados nos padrões já existentes (ATSC, DVB e ISDB), sendo seu principal foco a possibilidade de convergência com aparelhos celulares. As inovações introduzidas por estes padrões são modulação digital de sinal, mobilidade, transações bidirecionais, maior definição de imagem e portabilidade. 
O diferencial da tevê digital do Brasil apresenta três grandes oportunidades estruturais à inclusão social, através da inclusão digital, a redefinição do modelo de negócios em tevê aberta, em função da digitalização, e o desenvolvimento de uma sólida indústria nacional eletroeletrônica, capaz de atender às demandas do Brasil e do mundo digital (ZUFFO, 2003).

A escolha do modelo Japonês, de uma forma parcial, vai proporcionar o desenvolvimento de tecnologia nacional e de criação de um pólo industrial, para a produção dessa nova tecnologia, sem ter que importar outras.

E o profissional telejornalista, como fica nessa nova fase? A perspectiva é que ele se adapte rapidamente, como vem ocorrendo em todo o processo de evolução da televisão. A nova batalha que o telejornalista brasileiro vai travar será com a interatividade. Para o profissional, de acordo com o diretor geral da Rede TV e jornalista Amilcare Dalevo ${ }^{65}$, o momento mais importante da tevê digital será a interação, porque este será o canal de retorno para essa proposta toda. Por isso, o profissional que vai estar qualificado para trabalhar no telejornalismo digital deverá ter algumas características básicas, como uma estreita ligação e grande conhecimento de informática, além de facilidade para lidar com novas tecnologias. De acordo com Dalevo, o jornalista, no geral, tem dificuldade de aceitar as novidades, como ocorreu com a digitalização total da Rede TV:

Nós só conseguimos implantar isso porque foi top dow, o negócio.
Porque havia, no começo uma resistência muito grande, né! As
pessoas falavam meio assim: se fosse bom, a Globo já tinha feito. Isso
não vai funcionar. Até que teve um feriado lá, em que nós arrancamos
todos os VTS, todas as fitas e colocamos os computadores e todo
mundo achou, que o jornal não ia pro ar, e hoje ninguém vive sem,
porque você consegue, num programa ao vivo, colocar no ar qualquer
matéria, desde o dia de estréia, em um minuto (DALEVO JÜNIOR,
2006).

A Rede TV é a primeira emissora brasileira a manter o arquivo de imagens digital e a realizar todas as operações que envolvem a colocação de um telejornal ou programa, ao vivo, no ar, totalmente informatizado. Ela aboliu o uso de fitas, de VTS, de teleprompter, de gerador de caracteres e do script impresso. Toda essa operação é feita integrada no computador e tem um software que controla todos os outros, chamado de digital news.

\footnotetext{
${ }^{65}$ Entrevista gravada em São Paulo, em 9 de novembro de 2006.
} 
A Rede TV, preocupada com essa dificuldade tecnológica, criou um programa de estágio, que é chamado TTP - Television Traine Program, onde são recrutados estagiários de várias áreas, como Rádio e TV, Jornalismo, Engenharia, Administração e Direito. Durante o treinamento, o estagiário passa por todas as áreas para ter uma visão geral da empresa, antes de ir para a área específica dele. $\mathrm{Na}$ área específica, ele é treinado em todas as funções que pode desempenhar dentro da emissora.

O jornalista Alberto Luchette $^{66}$, que já convive há algum tempo com uma nova configuração televisual, através da allTV, que é a primeira emissora de tevê na internet do Brasil, faz uma análise crítica a respeito desse profissional, que deverá atuar na tevê digital.

Quando eu comecei, em 72, a gente escrevia a reportagem numa
Olivetti, com três folhas de carbono, para distribuir cópias. Em 88 ,
quando iniciou-se o processo de informatização no Estado, eu tinha
que fazer centimetragem de matérias, linhas de matéria. Tinha que dar
um título para a minha matéria e tinha que fazer um texto final. Por
quê? Porque aboliram os revisores. Sobrecarrego o meu trabalho?
Não! Eu tive que apurar melhor o meu texto. Isso foi bom pra mim
profissionalmente (LUCHETTI, 2006).

Para entender as novas exigências da tevê digital, ele conidera que o telejornalista deva ser um o profissional multimídia. "Ao meu modo de ver, é o melhor profissional que tem, por quê? Porque ele escreve, ele faz reportagem, ele edita e entrega o material pronto." Assim, pode-se concluir que, na tevê digital, o profissional deverá ter domínio de tecnologia e atuar em várias frentes de trabalho, ampliando, assim, o campo de atuação dele também para as áreas técnicas, dominando câmeras e ilhas de edição, além de todo o trabalho intelectual de conceber e produzir conteúdo informacional.

Hoje em dia, o ideal, em termos técnicos, é que não se trabalhe com fita nenhuma, tudo deve ser digital, desde a captação até a edição e exibição. Isso, de acordo com Leandro, faz uma grande diferença para o telejornalismo. "Muda um pouco a sua concepção de captar a realidade, tem que ter um pouco mais de discernimento, tem que ter um pouco mais de senso, quanto menores forem os recursos à sua disposição."

O grande problema do telejornalismo da tevê aberta, nos últimos anos, é que ele vem perdendo muita audiência em todos os países do mundo. Um dos

\footnotetext{
${ }^{66}$ Entrevista gravada em São Paulo, em 29 de março de 2006.
} 
motivos da diluição da audiência é a concorrência, que, no Brasil, foi aprimorada, principalmente pela chegada da internet. As pessoas, pelo menos certa classe mais abastada, não tem mais aquele hábito de antigamente, de esperar o telejornal para saber as notícias do dia. Isso era coisa de 15 anos atrás. Mas essa mudança não é geral ainda. Nas classes menos favorecidas, ainda se espera o momento do telejornal, para se informar, talvez até, pelo ato desta ser a única fonte de informação. Outro fator que influenciou essa diluição da audiência foi a tevê a cabo, que também só está disponível para uma pequena parcela da população.

Para Jordão, a digitalização não vai influenciar ou determinar uma nova forma de fazer telejornalismo e, como tudo o que é novo e se coloca à disposição do público, vai depender do uso que as pessoas e que os profissionais vão fazer dela. "A televisão é um veículo de informação que atinge a massa das pessoas. Com a digitalização, mais canais vão chegar às pessoas".

Os anos 90 também trouxeram as emissoras a cabo, com os primeiros canais de notícias. O primeiro deles foi a Globo News, que foi inaugurada em 15 de outubro de 1996, às oito e meia da noite. O primeiro programa foi um especial, que mostrava as principais atrações do canal, talvez, numa inspiração da tevê Tupi, que, na sua inauguração, nos anos 50, apresentou a sua programação. Inicialmente, a Globo News copiou o modelo americano da CNN, mas, depois, encontrou identidade própria com a repetição de telejornais da tevê aberta, noticiário de hora em hora e programas segmentados.

Depois de algum tempo, em 19 de março de 2001, entrou no ar a Band News, emissora da Rede Bandeirantes. Com visual utilizando as tarjas azul e vermelha, típicas da CNN, mantém até o momento o noticiário ininterrupto, sendo repetido a cada quarenta minutos, em média. A primeira editora executiva da Band News foi a jornalista Jacqueline Matoso Rodrigues ${ }^{67}$. Formada em jornalismo pela PUC de Minas Gerais, quando chegou a emissora, já havia trabalhado como produtora, pauteira, repórter e editora, editora-executiva e editora-chefe, em outras emissoras. Também tinha experiência no impresso, tendo trabalhado na Folha de São Paulo e trabalhado

${ }^{67}$ Entrevista gravada em São Paulo, em 02 de setembro de 2007. 
como free lancer para outras revistas e assessorias de imprensa. A sua primeira entrada na televisão aconteceu ainda no final dos anos 80 , quando era estudante e foi recrutada para estagiar na tevê Globo de Belo Horizonte, num esquema de cobertura de eleições. "Eu fui me identificando com o veículo e daí foram surgindo outras oportunidades". Neste período, as exigências eram um pouco maiores do que no passado. Era preciso ter ou estar cursando jornalismo e segundo Rodrigues: "o que agradava as pessoas era gente esperta, gente que pensava, assim tinha que ter agilidade de pensamento e operar rapidamente". Rodrigues nunca passou por treinamento específico, para trabalhar em telejornalismo. "Na verdade, o treinamento se deu muito no fazer, no cotidiano, no dia-a-dia, na prática, assim, era fazendo pra aprender, aprender-fazendo". O que admira ela é que a tecnologia mudou totalmente o jeito de fazer telejornalismo:

Na minha primeira experiência, a redação era de máquina de escrever. Então, era a gente colocar lauda e escrever na lauda e, depois, logo no início dos anos 90 , começaram a aparecer os primeiros computadores. Daí pra frente, nunca mais me deparei com máquina de escrever (RODRIGUES, 2007).

Outro detalhe, apontado por Rodrigues, desta evolução tecnológica é captação de imagens: "quando eu comecei, as emissoras ainda eram Umatic, depois veio a Bethacam e hoje as emissoras e produtoras estão procurando se instrumentalizar e instalar a digitalização; as fitas vão sumir das redações, vai ser tudo via servidor". Com relação à experiência de participação na implantação da Band News, Rodrigues relata que foi gratificante, pois participou desde o projeto no papel até a primeira transmissão e o primeiro ano do novo canal. O canal de notícias 24 horas Band News nasceu com algumas características diferentes das outras emissoras, porque não tem grade de programação com horários definidos. Ele transmite num mesmo esquema de noticiário, o tempo todo, a exemplo da CNN americana. Para isso, foi necessário definir um novo perfil profissional para os telejornalistas da nova emissora. De acordo com Rodrigues, buscou-se profissionais muito jovens para trabalhar: "não no sentido de formá-los, porque quando você pega um profissional jovem pra trabalhar, ele não trás aqueles vícios de redação, aquelas idiosincrasias ou toda uma experiência, que é difícil de mudar". O objetivo principal do canal é trabalhar a informação, o tempo todo, e buscar 
informação nova, o tempo todo. Para isso, a emissora propõe que o novo profissional busque a informação em todos os materiais produzidos pelo grupo Bandeirantes, que é composto pela tevê Bandeirantes e suas afiliadas, rádio Bandeirantes e Canal 21. A única diferença é que a Band News não tem produção própria. Ela utiliza imagens de agências de notícias e matérias de todo o grupo, para dar suporte à sua exibição contínua de noticiário.

Com a passar do tempo, a rede Bandeirantes colocou no ar o Band Esporte - um canal especializado em esporte, como já existiam o Sport TV e ESPN Brasil, reforçando a segmentação dos conteúdos no telejornalismo. A última novidade em termos de segmentação aconteceu em setembro de 2007, com a implantação da Record News - o primeiro canal de notícias aberto do país.

Comprovando a hipótese de que o jornal impresso continua, nos anos 90, sendo uma grande fonte para novos telejornalistas, o jornalista Rodrigo Luiz Brito Vianna ${ }^{68}$, conhecido como Rodrigo Vianna, que também iniciou-se na profissão, neste período, trabalhou anteriormente no impresso. Ele se formou pela Fundação Cásper Líbero, em 1990, e começou como free lancer na Folha da São Paulo. Depois, passou a repórter, redator e editor-assistente, totalizando três anos no impresso. "Gostei muito, foi uma escola importante, mas ficava frustrado por não conseguir fazer matérias. Eu estava querendo fazer as minhas matérias e no jornal eu era redator". Em seguida, passou a cobrir férias na tevê Cultura de São Paulo, como repórter, até ser contratado para a função em definitivo. Mas, segundo Vianna, a saída do impresso para a televisão aconteceu na raça e com colaboração dos profissionais que o ensinaram na emissora. "Na tevê Cultura, era uma escola. Você não precisava estar pronto pro vídeo. Eu trabalhei com gente que me ensinou muito bem. Eu aprendi a fazer televisão na tevê Cultura." Ainda com relação às diferenças entre impresso e tevê, Vianna afirma que a primeira coisa que aprendeu é que na televisão o lead não está no começo da sua matéria, o lead está na cabeça do apresentador, a cabeça é texto que o apresentador lê. Outros macetes e diferenças foram sendo incorporados, aos poucos, com a vivência dentro da redação de telejornal: "esses macetes, como aproveitar a imagem e não ser tão

${ }^{68}$ Entrevista gravada em São Paulo, em 21 de dezembro de 2006. 
literal no texto, quer dizer, seu texto não precisa descrever exatamente o que está na imagem, tem que acrescentar, porque a imagem as pessoas estão vendo". Vianna ficou na tevê cultura até 1996 e, além de reportagem, fez, também, a apresentação do programa Opinião Nacional, em parceria com Heródoto Barbeiro. Depois, foi para tevê Globo de São Paulo, também trabalhou na emissora do Rio de Janeiro, fez parte da equipe do Globo Repórter por vários anos, produziu matérias para todos os telejornais de rede da emissora e saiu como repórter especial em 2006, depois de questionar a cobertura da eleição feita pela emissora. Atualmente, é repórter especial da Rede Record e apresenta programa de entrevista na Record News.

Para encerrar este capítulo, uma comparação entre as características dos profissionais que estavam em atividade nos anos $90 \mathrm{com}$ as perspectivas apontadas para a era da digitalização da tevê, pode nos fornecer pistas a respeito do futuro do telejornalista brasileiro. A chegada dos computadores e da internet nas redações, nos anos 90, colocou o telejornalismo em posição de destaque, em termos de agilidade. Isso pode indicar que, com a tevê digital, o meio televisão deva continuar na frente da transmissão de notícias em alta velocidade.

O início do processo de digitalização, no final dos anos 90, e a troca gradativa dos equipamentos, como, por exemplo, as ilhas de edição de corte seco por ilhas não-lineares, acelerou o ritmo de produção nas redações de tevê. A exigência para o futuro próximo, será de profissionais cada vez mais jovens, com mais ritmo e muito mais especializados nas novas tecnologias. $\mathrm{Na}$ era digital, estes profissionais serão valorizados, devido ao conhecimento agregado que terão para oferecer às emissoras.

A década de 90 trouxe uma nova configuração para as redações de telejornalismo, pois o trabalho da rádio-escuta está tomando um outro rumo, dentro da redação. Devido à utilização da internet, não há mais a necessidade de ouvir rádio. Isso está ocasionando um enxugamento do número de profissionais e transformando-os numa espécie de faz tudo, como foi no início da implantação da televisão no Brasil.

Os canais segmentados em informação constituem um novo e amplo campo de trabalho para o telejornalista, mas este fenômeno acarretou a diminuição da audiência e a grande competitividade entre as emissoras. 
Os profissionais diplomados, apesar da crise de identidade por que passa o jornalista, com a possibilidade da desregulamentação da profissão, ainda são fundamentais. As empresas exigem o diploma para o exercício da profissão. Para os próximos anos, ainda é difícil prever o que deve acontecer com o futuro da formação acadêmica em jornalismo, porque depende de uma decisão do Supremo Tribunal Federal. Mas com as novas tecnologias e as novas exigências profissionais, será cada vez difícil uma pessoa sem formação acadêmica trabalhar como telejornalista.

\section{Capítulo 3 - Os modelos de telejornalismo brasileiro}

"A geração que foi criada sem a televisão não tinha um referencial, nem imaginava o poder deste meio de comunicação". Wallinho Simonsen - dono da TV Excelsior.

\subsection{A influência do modelo americano e do europeu}

Os modelos de telejornalismo adotados na Europa e nos Estados Unidos, atualmente, apresentam pouquíssimas diferenças entre si. Mas, entre o telejornalismo europeu e o americano, houveram diferenças drásticas no passado. Segundo Piccinin, desde a origem do telejornalismo Europeu até o século XX, praticava-se o jornalismo engajado, partidário, analítico. Já os americanos, criaram, nos anos 50, a escola do jornalismo "clean", asséptico, onde os mitos da imparcialidade e da objetividade passaram a ser defendidos como verdades inabaláveis, até hoje. Isso comprova a existência histórica de dois caminhos totalmente diferentes de conceber não só jornalismo, mas, também, o telejornalismo. Na Europa, a necessidade de engajamento, partidarismo e análise dos fatos deveu-se à própria origem do povo europeu e à sua maneira de ver, interpretar e analisar.

Uma referência, na sociologia, sobre as diferenças entre o europeu e o norte-americano, é o estudo realizado por Merton. "A comparação tem mais 
outro objetivo: propugnar a unificação dos campos de pesquisa social relacionados entre si, em busca da feliz combinação dos dois, que possua as virtudes científicas de ambos.e nenhum dos vícios supérfluos de um e outro" (MERTON, 1970: 536). Ele comparou os pesquisadores da sociologia do conhecimento, também denominada de "espécie européia", com os pesquisadores da sociologia das comunicações de massa, a "espécie norteamericana." O estudo mostrou que a corrente européia e a norte-americana defendem bandeiras opostas, assim como as diferenças entre os dois estilos de jornalismo que influenciaram o Brasil, com maior e menor identificação. A primeira diferença é relativa ao que Merton chama de bandeira defendida por cada lado, sendo que a européia dizia: "Não sabemos se o que dizemos é certo, mas pelo menos é importante." Isto revela uma valorização e engajamento nas suas próprias convicções. Já a norte-americana, dizia: "Não sabemos se o que dizemos é especialmente importante, mas pelo menos é verdadeiro", mostrando uma aproximação com da objetividade e a verdade, identificados no jornalismo americano (MERTON, 1970: 536). Outras perspectivas do diferencial entre as duas possibilidades teóricas analisadas por Merton (européia e americana) foram relativas à matéria e definição de problemas, as perspectivas de dados e fatos, as técnicas e processos de pesquisa, e, também, a organização social da pesquisa.

No quesito matéria e definição de problemas, a variante européia dedica-se a desenterrar as raízes sociais do conhecimento, para descobrir os modos em que o conhecimento e o pensamento são afetados pela estrutura social ambiente. Isto, segundo Merton, significa que "a sociologia do conhecimento interessa-se mais diretamente pelos produtos intelectuais dos peritos, ou seja, na ciência e na filosofia, como no pensamento político ou econômico." A variante norte-americana dá enfoque ao estudo sociológico da crença popular (cultura popular) "Focaliza-se, especialmente, sobre a opinião", relata Merton. Sendo assim, ele conclui que a vertente européia, com seu interesse pelo conhecimento, lida com a elite intelectual e a vertente americana, preocupada com a opinião popular, lida com a massa. $O$ pesquisador resume que as diferenças relativas à matéria e definição de problemas entre as duas correntes mostram que "o norte-americano sabe do 
que está falando, e isto não é muito; o europeu não sabe do que está falando, e isto é muito." (MERTON, 1970: 538)

Em relação às perspectivas de dados e fatos, as duas vertentes apresentam visões opostas. A variante européia, com seus largos objetivos, "quase desdenha ao estabelecer seus próprios fatos que se propõe a explicar" e a variante norte-americana, com sua visão limitada, "enfoca-se tanto sobre o estabelecimento do fato, que só de vez em quando leva em conta a pertinência teórica dos mesmos, depois que foram estabelecidos." (MERTON, 1970: 540). Concluindo este tópico, é possível, de acordo com Merton, estabelecer que "a variante européia chega a falar de assuntos importantes, de modo empiricamente discutível, ao passo que, o norte-americano, discute assuntos talvez mais banais de modo empiricamente rigoroso. O europeu imagina e 0 norte-americano olha; o norte-americano investiga a curto prazo e o europeu especula a longo prazo." (MERTON, 1970: 542)

As técnicas e processos de pesquisa começam a apresentar os seus diferenciais, ao constatar que a vertente americana utiliza uma abundância de técnicas e a européia, uma pequena lista. De acordo com Merton, a vertente européia "enfoca-se sobre as determinantes estruturais do pensamento", enquanto a norte americana "sobre as conseqüências sociais e psicológicas da difusão de opinião." Sendo assim, ele considera que, "enquanto uma concentra-se em torno da fonte, a outra em torno do resultado." Por fim, constata que "a européia pergunta como acontece que aparecem as idéias particulares; a norte-americana pergunta como essas idéias, depois que aparecem, afetam a conduta?"

$\mathrm{Na}$ organização social da pesquisa encontramos os europeus trabalhando, tipicamente, como intelectuais solitários, e os norte-americanos trabalhando com equipes de investigação ou como grandes organizações de pesquisa formadas por várias equipes. (MERTON. 1970: 549)

Com o processo da globalização e a desestatização das televisões européias, impôs-se um modelo liberal, como forma de sobrevivência, diante da concorrência. Houve, também, uma aproximação entre os modelos público e privado, colocando a TV Global, como a americana. O processo de globalização acabou proporcionando, também a americanização do mundo, ou pelos menos uma falsa idéia de que isso é a forma de sobreviver para o 
jornalismo mundial, sendo competitivo e fazendo parte de um processo onde a informação passa a ser mundializada. E a televisão, incluindo o telejornalismo, que é foco central desta pesquisa, acabou retomando o seu status de "uma janela aberta para o mundo. Por que não abri-la mais amplamente?" (Ernest Dicheter, apud Mello e Souza), em termos de informação mundializada.

Para Leal Filho (1997: 17), a diferença entre as televisões americana e européia está no tipo de contaminação que cada uma delas sofre; a primeira, é de cunho comercial, e a segunda, política. Desta forma ele justifica a adoção do modelo público de televisão acorrido na Europa ocidental. Os motivos para a adoção deste modelo público, segundo Leal Filho (1997: 17-18), são três: a origem cultural, a ordem técnica e a natureza política.

No sistema público europeu, de acordo com Blumer (Apud Leal Filho 1997: 23-25) existem seis características comuns, a saber: a existência da "ética da abrangência", a generalidade dos termos dos seus documentos de ordenação jurídica, a pluralidade, o papel cultural das emissoras, o lado positivo da alta politização e também, encontra-se numa zona de tensões entre cultura e comércio. Estas características apontam para a uma linha divisória bem demarcada entre o sistema público europeu e o modelo americano de tevê, onde uma tem preocupações éticas muito bem demarcadas e a outra apresenta um modelo que propõe uma padronização, com base na técnica.

O que Blumer chama de "ética da abrangência" está relacionado ao firme propósito de atender às expectativas de todo tipo de telespectador existente no raio de sua atuação. Isso fica mais claro, quando comparamos com o modelo público norte-americano, onde seriados são exibidos na televisão comercial e recitais de ópera são exibidos na televisão pública. $\mathrm{O}$ modelo europeu busca abranger os dois públicos.

Já a generalidade dos termos dos seus documentos jurídicos demonstra grande flexibilidade de interpretações, nas concessões dadas pelos governos. Estas são feitas na forma de cartas régias, licenças, mandatos ou contratos. Elas servem muito mais para balizar os objetivos gerais da emissora do que, para serem usados como instrumento de aplicação legal.

A pluralidade pode ser observada em vários níveis, como na multiplicidade dos tipos de audiência, na composição dos seus conselhos 
diretores e na noção de que a sociedade é multifacetada e precisa ser atendida por um serviço público de televisão.

O papel cultural das emissoras é observado através da concepção de seus fundadores, como instrumento responsável por sustentar e renovar as características culturais básicas da sociedade, através da participação de atores, músicos, escritores, teatrólogos e intelectuais em geral, para disseminarem o seu trabalho, dando, ao próprio telespectador, a oportunidade de acesso ao produto desses talentos.

A alta politização pode acabar gerando formas de controle e contracontrole, capazes de resultar na elaboração de programas balanceados, responsáveis pela elevação do grau de participação dos cidadãos nos destinos políticos da sociedade.

As tensões entre cultura e comércio são perceptíveis ao compararmos: "A propaganda nos estados Unidos foi tratada como visitante de honra do Broadcasting. Na Europa ela é uma visitante tolerada e recebe o mais humilde lugar da mesa" (Sepstrup, 1986: Apud LEAL FILHO).

Vários autores apresentam as diferenças entre o jornalismo europeu e americano, mas seguindo a mesma linha de raciocínio de que os dois divergem, radicalmente, entre si, tanto em forma, como em conteúdo. Puccinin esclarece que "o jornalismo europeu sempre explicitou seu posicionamento, até porque, por muito tempo, esteve preso ao controle do Estado, sofrendo forte influência e, por conta disso, nunca se admitiu imparcial e objetivo, por conhecer essa impossibilidade". Já para Drummond, "o jornalismo europeu tem uma abordagem mais pedagógica e uma interpretação crítica e intelectualizada dos fatos." (Apud PUCCININ). Herscovitz conclui que "o modelo americano é objetivo e apartidário, o modelo francês é mais subjetivo, opinativo, partidário e literário" (Apud PUCCININ).

Mas com o passar dos anos, esse modelo público vem sofrendo contaminação do modelo comercial e vem diminuindo essa diferença, que antes, os colocava em dois lados totalmente opostos. E o telejornal está diante 
dessa necessidade de "rumar num caminho único enquanto técnica, fruto desse processo de relações mundializadas."

E o que poderia ser chamado de telejornalismo brasileiro? A questão não é tão fácil assim, como parece, pois viemos de um telejornalismo radiofônico, conhecido como "rádio com imagens", evoluímos para a cópia do modelo americano, e, hoje, acredita-se que possamos ter desenvolvido o modelo brasileiro ou o que poderemos algum dia chamar de modelo latinoamericano.

Este modelo de telejornalismo vigente no Brasil, que desde a sua implantação, sofre a influência americana, porque começou utilizando tecnologia americana, com a implantação, em 1950, da primeira emissora, a TV Tupi. Depois, com os telejornais copiados dos americanos, como foi caso do primeiro telejornal de sucesso da televisão brasileira, o Repórter Esso, e, mais adiante, com a implantação do Jornal Nacional, que é o telejornal que está há mais tempo no ar, no país, cerca de 39 anos.

Nesse processo todo, algumas características foram totalmente copiadas e outras adaptadas ao estilo e à cultura brasileiros.

Um dos grandes problemas do telejornalismo brasileiro foi a ditadura militar, que se instalou na década de 60, e só terminou nos anos 80 , pois boa parte das técnicas aperfeiçoadas neste período tiveram que ser reinventadas depois e muitas não foram reconsideradas. O Brasil, neste período, era considerado uma "ilha de tranqüilidade". Essa ilha era cercada de censura, por todos os lados. O jornalista Armando Nogueira recorda essa época:

Nós não tínhamos o direito de nos emocionar com uma notícia, porque, antes de termos acesso a ela, recebíamos dos serviços de censura a informação que tal notícia, que nós ignorávamos, não poderia ser veiculada. Chegava o telex de censura e, diante dele, nada podíamos fazer, se não amargurar um incômodo sentimento de frustração. Mas nós sabíamos que, um dia, poderíamos nos reencontrar com a liberdade de informação, tendo já, depois de tão prolongado exercício da forma, condições de dar tratamento digno ao conteúdo do noticiário." 70

\footnotetext{
69 PUCCININ www.bocc.ubi.pt/pag/puccinin-fabiana-telejornalismo-americano-europeu.pdf acesso em 17 de fevereiro de 2008.

${ }^{70}$ MELLO E SOUZA, 1982: 95.
} 
O próprio "boa noite" de encerramento dos telejornais brasileiros já nasceu com a chancela do americano, pois segundo Armando Nogueira: "Buscava-se a informação de conteúdo lírico, dramático ou pitoresco, tratada de forma a levar o espectador, não às angústias das 'manchetonas', mas momentos de esperança, de serenidade ou bom humor." 71

A imagem dos apresentadores era algo que contava muito nos primeiros tempos. Não só imagem, como também a voz. Os apresentadores de telejornal, no geral tinham que ser bonitos e ter voz de timbre forte e, ainda, capacidade de interpretar num ritmo quase que uniforme, e com grande capacidade de improvisação diante das câmeras, pois, no início, não havia teleprompter e, por isso, era preciso improvisar, para não ficar só lendo e sim, alternando entre a leitura e o olhar para câmera. Outra preocupação que se passou a ter, a partir de 1975, foi com a roupa dos apresentadores. Ninguém podia ficar trajado "ao bizarro", era o que dizia Armando Nogueira. Foi nessa época que a consultora de moda Cristina Franco foi contratada na Rede Globo. Esse trabalho também ajudava a minimizar os problemas de vídeo, causados por alguns tipos de roupas de cores variadas, como xadrez e listras.

O texto é o reflexo mais perceptível da importação do modelo americano pelas emissoras, principalmente a Rede Globo. Esta emissora é vista como exemplo, pelo fato dela ter organizado e registrado todo o processo de vida dos telejornais, através de manuais e de publicações. Isso, também, deve-se ao fato dela ter treinado boa parte dos telejornalistas que hoje estão à frente dela e de outras emissoras, no Brasil.

Os manuais de redação copiados dos Estados Unidos, adaptados e difundidos pela Rede Globo, fizeram escola dentro e fora da emissora. Por isso, o texto ficou padronizado como sendo curto, claro, objetivo, direto e simples. O uso de adjetivos ficou praticamente proibido, para não dar conotação de opinião, devido ao problema de censura, que ocorreu no momento de sedimentação do telejornalismo no Brasil. Era um momento onde o país estava sob a égide de uma ditadura militar.

Alguns elementos, que foram fundadores e fundamentais para a definição de um padrão, que hoje em dia é seguido por todas as emissoras,

\footnotetext{
${ }^{71}$ MELLO E SOUZA, 1984: 78.
} 
como a limitação no tempo das matérias, a limitação no tempo das sonoras e a utilização do presente ou do futuro composto, ainda estão vigentes.

“O tempo ideal das matérias deve ser de 1' e 30", pois é preciso ter o dom da concisão para passar uma mensagem informativa, dentro deste limite, para o telespectador. Em algumas exceções, é possível se chegar a 2' ou mais, no caso de se tratar de uma matéria especial, com várias fontes de informação e grandes furos de reportagens. Só são permitidos tempos superiores em casos de grandes reportagens ou pequenos documentários, para programas específicos, fora do telejornal diário.

O tempo ideal para as sonoras é de 15" a 20", pois, acima disso, pode tornar-se cansativo para o telespectador. Quando o entrevistado fala além desse tempo, é indicado que se promovam alguns cortes e ajustes em sua, fala dele no momento da edição.

O tempo indicado no telejornalismo é sempre o presente, porque, se está sendo apresentado determinado assunto, significa que ele é factual, quente e aconteceu agora. Só quando ficar muito evidente que aquele fato não aconteceu agora, pode-se utilizar o passado, mas deve-se evitar começar com o passado. Quando se tratar de futuro, a preferência é pelo futuro composto, devido ao ritmo e tamanho das palavras. Se tivermos, por exemplo, que usar o futuro para a frase: o presente Lula viajará, é preferível usar: o presidente Lula viaja, ou: o presidente Lula vai viajar.

Podemos até chegar a um modelo brasileiro, que resultou da cópia do americano e que, com o tempo, acabou tendo alguns ingredientes próprios adicionados à sua essência, como as questões regionais, ou a previsão das marés, em cidades praianas brasileiras, presentes no nosso telejornalismo. Outro fator característico brasileiro é a curta carreira, baseada em suas imagens, pois nos Estados Unidos, os profissionais costumam envelhecer no vídeo e, aqui, este fato ainda é muito raro.

Um outro traço que pode ilustrar a influência americana no padrão brasileiro é o livro Telvision News, de Irving Fang, que serviu de inspiração para a criação do manual da Globo. Segundo Coutinho, o livro foi publicado em 1972 e tem um caráter de guia básico de treinamento em telejornalismo, e não possui grande relevância entre os títulos disponíveis nas bibliotecas americanas, já que haveria, hoje em dia, manuais mais recentes e atualizados, 
conforme a pesquisadora pôde constatar em seu estágio doutoral nos Estados Unidos. $^{72}$

O modelo americano de telejornalismo, de acordo com Coutinho, foi construído de forma gradual - "um processo iniciado em meados dos anos 40 e consolidado por volta de 1963." No mesmo momento, também acontecia, nos Estados Unidos, a criação dos outros formatos de informação, como debates, especiais ao vivo e documentários. Neste período, também foi definido tempo padrão dos telejornais americanos, com trinta minutos de duração. Como referência deste momento de implantação do telejornal americano na NBC, o produtor executivo da emissora, Reuven Frank, enviou um memorando, recomendando a busca, para o telejornalismo, um formato parecido com 0 drama: "toda notícia, estória jornalística deve, sem nenhum sacrifício de sua honestidade ou responsabilidade, apresentar os atributos da ficção, do drama. Ela deve ter estrutura e conflito; problema e desenvolvimento; nascimento e queda da ação; um início, meio e fim." (REUVEN FRANK apud EPSTEIN, 1973: 05). Este memorando estabeleceu a fórmula básica para as notícias da tevê Americana. Isto se aproxima muito das recomendações propostas no Manual de Telejornalismo da Globo.

De acordo com Epstein, existem cinco modelos de organização da informação na TV: modelo dialético; modelo irônico; pacote nacional; história de ação e modelo da nostalgia.

O modelo dialético determina que cada história deva apresentar os dois lados de uma questão, de acordo com o formato ponto-contraponto, com os repórteres fornecendo uma espécie de síntese da matéria, no final. Esse formato permite, também, garantir a obediência das premissas da Federal Communication Comission (FCC), relativa aos informativos televisivos.

O segundo modelo (irônico) só entra em vigor, quando não é possível apresentar um balanceamento de opiniões. Sem adotar posturas polêmicas, a sugestão é a elaboração de um texto com ironias e brincadeiras.

Uma alternativa utilizada para nacionalizar as histórias jornalísticas nos telejornais é o pacote nacional. Neste modelo, duas ou mais histórias são

\footnotetext{
${ }^{72}$ http://www.intercom.org.br/papers/nacionais/2005/resumos/R0647-2.pdf - acesso em 30 de junho de 2008.
} 
colocadas juntas, adicionando um caráter nacional à matéria jornalística televisiva.

No modelo história de ação, a narrativa se organiza a partir de um cenário, onde se desenrolam os posicionamentos e tomadas de atitudes de grupos em oposição. O destaque da história é mostrado através de situações de tensão entre os envolvidos, com entrevistas e narração que apresentam as diferenças entre eles de forma clara, preparando os telespectadores para o desenrolar da ação.

Por último, o modelo nostalgia tem como foco central um valor, visão tradicional ameaçada ou substituída por uma mais moderna. A história é contada em termos de conflitos e valores, através da narração do repórter ou locutor, entrevista e/ou edição de imagens.

Para esta breve apresentação do modelo americano de telejornalismo o livro Notícias do nada - Televisão e as notícias, de Edward Jay Epstein, é uma obra fundamental, devido à sua contextualização histórica do assunto, o que, no caso desta pesquisa, permitiu um aprofundamento e um entendimento das raízes do telejornalismo estadunidense.

Algumas das causas que podem justificar essa nossa proximidade e até promiscuidade com o modelo americano pode estar fundada na teoria desenvolvida pelo ex-presidente Fernando Henrique Cardoso, a respeito da dependência cultural na América Latina. Apesar de se tratar de uma teoria econômica, serve para dar conta do atrasado estágio do Brasil e a América Latina, e da relação com os países do chamado primeiro mundo. A teoria da dependência aplica o binômio centro/periferia à análise da realidade brasileira. De acordo com Luciano Pires ${ }^{73}$, numa interpretação da teoria, na dependência, supõe-se que os países periféricos (subdesenvolvidos) tornam-se dependentes dos países (desenvolvidos) e, por isso, são submetidos a uma exploração crescente, que reforça cada vez mais essa conexão entre dependência e exploração, a ponto de se constituir num ciclo que se realimenta sistematicamente. Segundo a teoria, esse ciclo de dependência e exploração se faz presente em três dimensões: econômica, política e cultural. Sendo que, na econômica, ela está subdividida em três formas: comercial (utilizamos o

\footnotetext{
${ }^{73}$ http://www.brasileirospocoto.com.br/idealbb/view.asp
} 
modelo similar ao americano de televisão, de modelo comercial), financeira e tecnológica (a implantação da televisão no Brasil foi totalmente baseada na tecnologia americana, num primeiro momento, nos anos $50 \mathrm{e}$, depois, definitivamente implantada, através do acordo da Rede Globo com o grupo Time-Life). Na política, está presente na internacionalização dos centros de decisões, através de organismos internacionais como ONU, OMC e FMI. Na cultural, que esta mais diretamente ligada ao nosso modelo de telejornalismo, pode ser explicada pela assimilação de valores, hábitos, ideais e comportamentos dos países centrais (no caso em estudo, nesta pesquisa, do americano), por parte das populações dos países periféricos.

O historiador americano David Landes, no seu livro $A$ Riqueza e a Pobreza das Nações, declarou que essa doutrina promove a impotência e o ressentimento. Segundo ele, mesmo ela sendo verdadeira, deveria ser deixada de lado porque:

a teoria é uma espécie de desculpa esfarrapada, que joga a culpa pelo atraso da América Latina no maquiavelismo dos impérios do Hemisfério Norte. $\mathrm{Na}$ verdade, a teoria da dependência surgiu como reflexão sobre os modelos alternativos de desenvolvimento e, bem antes que a palavra globalização entrasse em moda, para mostrar que os destinos de países ricos e pobres se encontram interligados." ${ }^{74}$

Mas o autor admite que, no decorrer dos séculos, haja relações predatórias entre os países ricos e os pobres, mas segundo ele "isso não justifica medidas isolacionistas. Os países pobres precisam aprender, e o melhor jeito de aprender é abrir-se."

Outra possibilidade teórica para explicar o motivo do telejornalismo brasileiro ter sido baseado no modelo americano se funda, ou se aproxima da teoria da hegemonia cultural de Gramsci, onde ocorrem as batalhas ideológicas pela conquista da hegemonia cultural, que, no caso do Brasil, foi, num primeiro momento, imposta, devido à questão da dependência, como vimos anteriormente. A contribuição de Gramsci é sobre o embate pela hegemonia no seio da sociedade civil - a partir de sua teoria Marxista ampliada do Estado - e leva-nos a repensar o papel desempenhado pelos meios de comunicação, em especial a televisão e o seu processo evolutivo no Brasil. É possível

\footnotetext{
${ }^{74}$ http://veja.abril.com.br/251198/p 182.html acesso em 07 de julho de 2008.
} 
analisarmos os meios de comunicação (neste caso específico, a televisão) não apenas como suportes ideológicos dos sistemas hegemônicos de pensamento, mas, também, como pontos de produção de estratégias para reformular o processo social, através da veiculação de campanhas, idéias e pensamentos hegemônicos. Não se pode também deixar de reconhecer a sistemática reverberação dos discursos dominantes na mídia, considerando que debates, polêmicas e contra-discursos aparecem nos conteúdos informativos, mesmo que numa freqüência menor do que seria ideal, mas, hoje em dia, numa proporção maior do que de décadas atrás. No atual estágio informacional que se vive, com informação abundante e em tempo real, os paradigmas evoluem e a relação com o público se refina. O elemento marketing, que é mais sutil, sedutor e fascinante é usado para atrair cidadãos-consumidores, com novas técnicas de apelo, como é o caso da interatividade, em substituição às disciplinas clássicas de reprocessamento ideológico.

De acordo com Denis de Moraes, para Antonio Gramsci, o conceito de hegemonia caracteriza a liderança cultural-ideológica de uma classe sobre as outras. No caso do telejornalismo brasileiro, isso ocorreu em função do fator novidade, que era a televisão nos anos 50, e com quem a trouxe ao convívio brasileiro. Para ele, as formas históricas de hegemonia sempre são as mesmas e variam conforme a natureza das forças sociais que a exercem, 0 que nos leva a concluir que a dependência cultural do Brasil fez com que os americanos nos impusessem a ideologia deles, como forma de nos ajudar a evoluir tecnologicamente, economicamente e culturalmente. Gramsci afirma que os mundos imaginários funcionam como matéria espiritual para se alcançar um consenso reordenador das relações, conseqüentemente orientado para a transformação.

A etimologia da palavra hegemonia, que deriva do grego eghestai, significa "conduzir", "ser guia", "ser chefe", e do verbo eghemoneuo, que quer dizer "conduzir", e, por derivação, "ser chefe", "comandar", "dominar". Eghemonia, no grego antigo, era a designação para o comando supremo das Forças Armadas, tratando-se, portanto, de uma terminologia com conotação militar. O eghemon era o condottiere, o guia e também o comandante do exército. Isso nos leva a fazer uma reflexão sobre os Estados Unidos ter sido o nosso comandante, no processo de implantação da televisão, e, depois, ter 
continuado a conduzir o processo de desenvolvimento de um telejornalismo brasileiro, através do domínio e da cópia das técnicas, que houve ao longo de toda essa trajetória. ${ }^{75}$

Outra referência importante, ao lidarmos com a influência americana sobre o telejornalismo brasileiro, é o trabalho desenvolvido pelo jornalista Carlos Eduardo Lins da Silva ( $O$ adiantado da hora - a influência americana sobre o jornalismo brasileiro), onde o autor traça uma comparação entre os dois países, os seus jornalismos e os agentes da influência.

Ao se fazer uma comparação entre os dois países, em relação ao histórico ocorrido ao longo do tempo, de acordo com Silva, os Estados Unidos foram, em 1824, o primeiro país a reconhecer a independência brasileira, mesmo que isso fosse contra alguns princípios básicos da democracia americana. Era uma estratégia de incentivo à emancipação do continente, em relação à Europa, que historicamente foram os primeiros a dominar a região. $\mathrm{Na}$ época colonial, o primeiro brasileiro a demonstrar simpatia pelos americanos foi Ruy Barbosa. Depois, foi Monteiro Lobato, que viveu em Nova Yorque durante quatro anos e estabeleceu convicções de que a única maneira do Brasil superar a pobreza era imitando o espírito empreendedor americano. Foi só em 1940 que o governo brasileiro se alinhou com o americano e iniciou uma política de conveniência:

\begin{abstract}
recebeu em troca o apoio americano ao estabelecimento de bons preços para o café no mercado internacional, assistência econômica e técnica para diversos projetos de industrialização no Brasil, fornecimento de armas, auxílio para a construção de aeroportos e inúmeras outras vantagens. ${ }^{76}$
\end{abstract}

Em contrapartida o Brasil enviou tropas para combaterem do lado americano, instalou bases militares americanas em seu território e passou a dar apoio às políticas internacionais dos Estados Unidos. Aos poucos, as trocas foram aumentando, pois havia a convicção de que o Brasil poderia transformar-se numa sociedade parecida com a deles. O avanço material, segundo Silva, ocorreu nos primeiros anos da década de 50, como foi o caso da implantação

\footnotetext{
75 MORAES, Denis http://www.acessa.com/gramsci/?page=visualizar\&id=297 - acesso em 30 de junho de 2008.

${ }^{76}$ SILVA, 1991: 44.
} 
da televisão no Brasil. Mas nesta mesma época, começaram a surgir sinais de séria contestação nacionalista contra os Estados Unidos. Mesmo com um esfriamento das relações entre os dois países, no campo da cultura e da economia, a influência americana continuava a crescer, o que explica a importação da tecnologia americana, na implantação de todas as emissoras brasileiras da década de 50.

Nos anos 60, algumas manifestações de rua contra os Estados Unidos ocorreram no Brasil, em função da influência dos valores de esquerda no meio intelectual. O campo da cultura recebia maior oposição, devido à tentativa de valorização da cultura nacional, mas o processo de influência continuava o seu curso. O golpe militar de 1964 recebeu o apoio do governo dos Estados Unidos e consolidou a presença americana na economia e na diplomacia brasileira.

Nos anos 80, a dívida externa do Brasil foi responsável pelo principal conflito entre a população brasileira e os americanos pois na fase anterior, caracterizada pelo "milagre econômico", consolidou-se grande parte desta divida junto à instituições financeiras vinculadas aos Estados Unidos.

A imagem americana no Brasil, apesar de tudo, continuava positiva e dependente, pois boa parte dos meios de comunicação continuava veiculando um grande número de mensagens produzidas, originalmente, nos Estados Unidos. Inclusive o nosso jornalismo, continuava cada vez mais próximo do americano. Este fenômeno pode ser explicado por dois fatores: o econômico e o cultural, conforme já foi observado anteriormente nesta pesquisa.

A conseqüência desse processo de internacionalização do país é que o Estado tem uma atuação proeminente nas sociedades periféricas, diferentemente dos países de capitalismo central, como é o caso dos Estados Unidos. E no caso do estudo específico da comunicação, o Estado garante a sobrevivência de veículos de comunicação, mesmo em sociedades onde a iniciativa privada não tem condições de arcar com os investimentos iniciais que a atividade requer. Como foi o caso da formação, no Brasil, de uma rede nacional de comunicação, inicialmente, através de microondas, e, depois, via satélite, para levar a televisão a todos os cantos do país, com a criação da Embratel.

De acordo com Silva, para entender o fenômeno cultural que envolve a relação Brasil - Estados Unidos, devemos observar que a tradição latino- 
americana é ibérica, enquanto a americana é angla. O Brasil, na tradição ibérica, de forma inconsciente, filtra os anglo-americanos, mesmo quando eles são assumidos como os melhores, por indivíduos e instituições. (SILVA, 1990; 51)

Quando Silva faz um paralelo entre os dois jornalismos, o americano e o brasileiro, algumas características são apresentadas. No começo, ele estabelece as possibilidades de jornalismo existentes, de acordo com Siebrt, Peterson e Schramm, de 1956, onde são apresentados quatro modelos distintos de jornalismo. O primeiro libertário, com expressão máxima nos Estados Unidos; de responsabilidade social, como se pratica na maior parte da Europa Ocidental; o autoritário, com exemplos nos países de Terceiro Mundo; e o comunista, nas sociedades socialistas. É importante registrar, que nos dias de hoje, é mais difícil identificar claramente tais modelos, devido ao universo multinacionalizado que vivemos. Sabemos que o modelo americano tem grande influência em todo o mundo. No Brasil, essa influência é muito forte no que diz respeito ao formato e às técnicas utilizadas, mas, se formos comparar em termos de conteúdo, podemos nos surpreender ao observarmos a constatação do jornalista Amauri Soares, que passou os últimos 5 anos nos Estados Unidos e que agora, de volta ao Brasil, estabelece:

\begin{abstract}
do ponto de vista da qualificação da formação, os americanos andaram muito mais depressa e foram muito mais longe. Porque nós entramos pelo nosso caminho do locutor, com o não envolvimento com o que está sendo produzido. Quantos anos nós demoramos pra botar a figura do âncora? Não pelo motivo, mas pelo que isso significa, quer dizer a pessoa que está apresentando o jornal ajudou a fazer, produziu, às vezes é o editor-chefe. Tomou decisões, está capacitado pra reagir, informar, completar uma informação e dialogar com o repórter. (SOARES, 2008)
\end{abstract}

Um dos aspectos que também fazem o diferencial entre o jornalismo brasileiro e o americano diz respeito ao público leitor, pois os Estados Unidos, de acordo com Silva, tem um público razoavelmente homogêneo, que consome jornais como um produto, porque: "as barreiras do analfabetismo foram superadas quase por completo, as classes médias cresceram a ponto de se transformarem em maioria absoluta da população e tudo isso aconteceu há mais de cem anos". Já no Brasil, o caso foi completamente diferente, pois o sonho de se ter uma imprensa tão estruturada e com a qualidade da americana só pode se tornar realidade a partir da década de 50, e, em especial, nos anos 
70, devido à própria exigência da sociedade brasileira, que conseguiu transformar alguns negócios jornalísticos em empreendimentos, como imaginou Patrocínio, em 1887, com o seu Cidade do Rio.

Mesmo tendo sido transplantado para o Brasil, o modelo americano de jornalismo não ficou exatamente igual. Isso, segundo Silva, pode ser comprovado através da história do próprio jornalismo americano, que foi um transplante de fórmulas jornalísticas da Inglaterra do século 18, mas que foi alterado pelas condições específicas dos Estados Unidos.

Silva elenca na sua pesquisa uma série de agentes da influência americana sobre o Brasil. O primeiro deles são os profissionais daqui, que vão viver por algum tempo nos Estados Unidos, e, quando retornam, começam a usar técnicas ou conceitos que aprenderem ou viram lá. O primeiro exemplo que ele cita é o português Hipólito da Costa Pereira, editor-responsável pelo primeiro jornal que circulou no Brasil, a partir de 1808, que após uma temporada na Filadélfia, para estudar as atividades agrícolas, passou a dedicar-se ao jornalismo. Outro que se tornou um americanófilo, depois sua estadia nos Estado Unidos, no século 19, foi Ruy Barbosa. No final da década de 1860, Quintino Bocaiúva também estivera nos Estados Unidos, e, de volta ao Brasil, fundou $A$ República. Nesse período, ainda não haviam se manifestado em características propriamente ditas a influência americana sobre o jornalismo brasileiro, a contribuição era eventual. A influência predominante no Brasil ainda era européia, a contar pela fundação da filosofia brasileira, por Ferrão Moniz e Faria Brito, baseada no pensamento francês e alemão. Somente depois da Primeira Guerra Mundial é que se pôde observar a materialização de características americanas, quando Gilberto Freyre passou quatro anos em estudos nos Estados Unidos e, na volta, ficou à frente do jornal A Província de Recife, onde tentou, pela primeira vez, implantar um manual de redação. De acordo com Marques de Melo, a tentativa fracassou, porque o jornalista brasileiro resistiu ao método e à técnica. A influência americana no Brasil aumentou na década de 20, devido às agências americanas, que monopolizavam o noticiário do exterior na imprensa brasileira. De acordo com Silva, em 1926, os americanos realizaram um congresso pan-americano de jornalistas em Washington, onde foram lançadas as bases para a formação da Sociedade Interamericana de Imprensa. O objetivo era a realização de 
intercâmbio de pessoas e material, através de bolsas de estudo e contatos entre jornalistas. Do Brasil, compareceram 14 jornalistas, entre eles Gilberto Freyre, Nestor Rangel Pestana, Edgar Leuenroth e Herbert Moses. Havia, também, nesta época, uma corrente de jornalistas brasileiros que eram resistentes a essa influência, como Alceu Amoroso Lima, Antonio Torres e Agripino Grieco. Mesmo assim, o processo de aproximação se intensificou na década de 30 e nos anos 40 algumas alterações foram identificadas na imprensa brasileira como, por exemplo, a troca do artigo de fundo pelo editorial e do nariz-de-cera pelo lead. Foi só nos anos 50 que o lead passou a ser forma hegemônica na imprensa brasileira. Oficialmente, o primeiro jornal brasileiro a adotar o lead e o manual de redação como norma foi o Diário Carioca, por influência de Pompeu de Souza, que havia trabalhado entre 1941 e 1943 no serviço brasileiro da "Voz da América" nos Estados Unidos. Também é desta época a utilização da expressão copy-desk, para designar o profissional que trabalha na mesa de copy, que também é uma influência americana.

Em 1940, os Estados Unidos cria o "Office of the Coordintor of Interamerican Affairs" para intensificar a distribuição de artigos à imprensa latino-americana e patrocinar viagens de jornalistas à América. Sob o comando de Nelson Rockefeller, o escritório investiu, em 1940, US $\$ 3,5$ milhões e, em 1942, US\$ 38 milhões (Gerson Moura Apud Silva; 1990).

No final dos anos 50 e início dos anos 60 alguns jornalistas de grande importância foram morar nos Estados Unidos trazendo relevantes reformas para a imprensa brasileira. Foi o caso do jornalista Alberto Dines, um dos responsáveis pela grande reforma por que passou o Jornal do Brasil, nos anos 60. Entre as mudanças, estavam o princípio da organização temática dos textos no jornal, a implantação de um departamento de pesquisa e o incentivo à especialização jornalística. (SILVA, 1991: 81)

Outro fator apontado por Silva como parte dessa influência americana foi o caso Watergate, ocorrido nos anos 70, como uma ajuda para cimentar a hegemonia ideológica dos conceitos da escola americana de jornalismo no Brasil, porque mostrou que só numa sociedade com esse tipo de jornalismo, como o americano, é possível à imprensa exercer um papel político tão predominante. (SILVA, 1991: 83 - 84). 
Silva ainda elenca como elemento influenciador a expansão dos cursos de jornalismo no Brasil, a partir de 1969, com a regulamentação da profissão e a exigência do diploma de bacharel na área para o exercício da atividade, como fonte à disseminação dos valores e técnicas do jornalismo americano.

No caso do telejornalismo, a influência mais relevante e pioneira aconteceu com os jornalistas Alice Maria e Armando Nogueira, da tevê Globo, que nos anos 60 foram convidados para conhecer o telejornalismo americano e importaram praticamente tudo o que viram e aprenderam lá, para criar o Jornal Nacional.

\subsection{0 telejornalismo brasileiro}

O telejornalismo brasileiro, apesar de toda influência que recebeu, tanto dos europeus e principalmente dos americanos, revela ao longo de sua existência algumas peculiaridades únicas, que serão catalogadas a partir da observação feita pelos 37 telejornalistas entrevistados durante este trabalho, e, também, através de pesquisas anteriormente realizadas.

No campo bibliográfico, dois trabalhos contribuem para compreendermos como se organizou o telejornalismo brasileiro. $O$ primeiro $(O$ Âncora no telejornalismo brasileiro), de 1993, onde Sebastião Carlos Squirra estudou e revelou o modelo de telejornalismo praticado nos Estados Unidos e a sua influência no telejornalismo brasileiro, praticamente da mesma maneira conforme já havia sido constatado, por outros pesquisadores, no jornalismo impresso. E o segundo (Telejornalismo no Brasil - um perfil editorial), de 2000, onde Guilherme Jorge Rezende faz uma breve retrospectiva do telejornalismo no Brasil e também uma análise de três telejornais brasileiros (Jornal Nacional, TJ Brasil e Jornal da Cultura), revelando duas categorias diferentes informativa e opinativa.

O trabalho de Squirra apresenta como se deu o processo de introdução da figura do âncora no telejornalismo brasileiro, usando como base o caso do jornalista Boris Casoy, na época no TJ Brasil do SBT, que apesar de não poder ser considerado o primeiro âncora brasileiro, fornece valiosas contribuições. $O$ pesquisador fez um levantamento histórico, mostrando que a primeira referência ao âncora no Brasil foi a experiência do jornalista Costa Manso, em 
1976, na cobertura das eleições municipais, pela tevê Globo. Depois, tem a referência do jornalista Alberico Souza Cruz, ao trabalho realizado por Carlos Monforte, nos anos 80, na tevê Globo. Carlos Nascimento também teve uma curta experiência como âncora, no final dos anos 80 na tevê Cultura de São Paulo, mas logo depois reproduziu a forma tradicional de apresentação, quando voltou para a tevê Globo.

Uma outra constatação de Squirra (1983), que dá indícios da influência do modelo americano e não da cópia efetiva, no Brasil, é o depoimento do correspondente internacional Lucas Mendes, a respeito do formato do telejornalismo Brasileiro:

\begin{abstract}
Nós copiamos todo o formato deles (os norte-americanos), mas não incluímos os produtores na nossa receita. Provavelmente por questão de economia, aquela sai mais caro. Enquanto o repórter faz produção, ele deixa de fazer reportagem. '60 Minutes', o programa jornalístico de maior sucesso na televisão americana, tem cinco repórteres e 120 produtores. No nosso Globo Repórter, que é um programa que tem formato semelhante, a proporção parece ser exatamente inversa. Por isso, TV no Brasil muitas vezes pode sair mais caro, mais difícil e com pior resultado.
\end{abstract}

O correspondente admite a cópia, mas não totalmente. Talvez esteja aí uma adaptação do modelo americano à realidade brasileira, de acordo com as suas peculiaridades e realidade.

Squirra observa que a influência americana é anterior à associação da Rede Globo ao grupo Time-Life. Ela remonta ao ano de 1952, com a transposição do Repórter Esso para a televisão, através de um Manual de Produção do Repórter Esso, uma publicação baseada no programa exibido na televisão americana, em 1946, com o título de O Carretel de Notícias da Esso, e que em 1947, passou a chamar O Repórter Esso ("The Esso Repórter"), (SQUIRRA; 1983: 43). Squirra, ainda, observa três evidências da influência americana do Repórter Esso:

A primeira evidência é a de que a agência de notícias produtora do telejornal era a norte-americana UPI ("United Press Internacional"). A segunda, é o fato de que o programa foi encomendado à agência McCann Erickson - uma agência Multinacional - por outra multinacional, a Esso. E terceiro, porque tinha num similar norteamericano, o The Esso Repórter, o seu padrão original, conforme descrito por Edward Bliss jr. Em seu livro Now the News-the story of broadcast journalism (SQUIRRA, 1983: 175). 
Com relação ao Manual de Telejornalismo da Globo (que serviu de base para modelo vigente no país, hoje), o pesquisador recorda que a iniciativa partiu da aproximação dessa rede aos padrões administrativos e produtivos americanos. Depois, nos anos 80, a central Globo de Jornalismo passou a realizar os Encontros de Telejornalismo, onde os profissionais produziam textos, que foram editados pela sucursal de São Paulo e deram origem ao Manual de Telejornalismo publicado internamente, em 1985. Um dos profissionais responsáveis pelos Encontros de Telejornalismo, Woile Guimarães, revela o objetivo desta iniciativa:

\begin{abstract}
Acima de tudo, uma tentativa de registro de nossa experiência diária na televisão. Todos que enfrentamos esse dia-a-dia, que passamos por esse processo de aprendizado de uma nova linguagem jornalística, que nos assustamos às vezes com a força e o alcance do veículo e a responsabilidade que daí advém, todos nós sentimos, ao longo desse aprendizado, o processo desgastante dessa adaptação. Não há nada, ou quase nada, escrito; as lições se diluem em memorandos, são mal registradas, mal entendidas (Guimarães Apud SQUIRRA, 1983: 116).
\end{abstract}

Outra iniciativa registrada por Squirra é o Manual provisório de Telejornalismo do SBT - editado em 1989, com uma condensação de manuais de jornalismo das redes $A B C$ e NBC.

A figura do âncora é o ponto central do trabalho de Squirra, por isso, ele traça uma linha histórica, onde consegue determinar, "o personagem que seguramente mais se identifica com as notícias nos telejornais nos EUA é a figura do apresentador, que no país recebeu, ainda na década de 50, o nome de âncora ("anchorman")." (SQUIRRA, 1993: 65)

A figura do âncora brasileiro, personificada por Boris Casoy, buscou a inspiração no modelo americano, através de algumas fitas trazidas dos Estados Unidos, pelo jornalista Marcos Wilson, que era diretor de jornalismo do SBT, na época. Mas, o que aconteceu é que não ficou exatamente igual, porque na última hora se resolveu acrescentar o comentário. Esse fato tornou o jornalista Boris Casoy o único a fazer esse tipo de apresentação e a ter liberdade para comentar as notícias, de acordo com as suas convicções (SQUIRRA, 1983: 165).

Em sua pesquisa, Rezende também reafirma várias questões relativas à forte influência do modelo americano, através dos mesmo argumentos e explicações já observadas, e acrescenta o caso da tevê Manchete: 
outra aparência do aproveitamento do Television News na transposição do modelo norte-americano para o telejornalismo brasileiro é o Manual de Repórteres e Editores da extinta TV Manchete, publicado na revista Comunicação, número 29, pelo Departamento de Jornalismo da Bloch Editores. O periódico não indica a data precisa de sua publicação, o que impede de saber se ocorreu antes ou depois da edição do Manual da Globo. O que incorpora, contudo, é o conteúdo dos dois manuais, praticamente idênticos, apresentando diferenças irrelevantes (REZENDE, 2000: 91).

Durante esta pesquisa, 37 jornalistas foram entrevistados a respeito de suas trajetórias profissionais como telejornalistas, e dentre as perguntas foi questionada a possibilidade do telejornalismo brasileiro ter sido copiado do americano. Todos os entrevistados admitiram a cópia do telejornalismo americano, mas algumas reflexões feitas por alguns deles merecem ser mencionadas, pois tratam-se de referenciais para uma formulação própria para o telejornalismo brasileiro.

Com relação ao modelo americano ter sido copiado, implantado e efetivado no Brasil, isso pode ter ocorrido num primeiro momento, não por causa do acordo da Rede Globo com o grupo Time Life, mas, sim, porque foi um formato, que realmente se mostrou bom, de apresentação. Para aquele momento, de acordo com Costa: "eu acho que serviu, mais depois deixou de ser aquele apresentador, que era simplesmente um apresentador, um ator de notícia, para vir realmente o profissional que vive na redação. Se foi uma cópia, não foi uma cópia ruim, não". Mercadante também reconhece que a televisão brasileira copiou o modelo americano, mas segundo ele "copiou certo, de quem fazia melhor". Mas, para ele, hoje, o telejornalismo brasileiro tem uma personalidade própria: "tanto é que os americanos que vem aqui, às vezes, fazer matéria e olhar um pouco, ficam bobos porque não encontram nada igual, nem na Europa." Para ele, essa questão é simples, porque nada é exatamente igual e o Brasil não faria nada igual ao americano, são coisas muito distintas.

Para Jordão, o Brasil tem uma identidade própria até no seu jeito de fazer televisão, mesmo que tenha sofrido a influência americana.

Leal Filho afirma que o Brasil copiou o modelo americano naquilo que o telejornalismo americano tem de bom, na figura do âncora: "o bom âncora tem a capacidade do improviso e usa esse improviso." 
Squirra é categórico ao afirmar que realmente copiamos, mas não exatamente igual:

com certeza, totalmente não tem nenhum, tem muita coisa brasileira. $O$ Brasil tem uma coisa diferente da América Latina e muitos países do mundo... Quer dizer, ele importa o modelo, mas tem uma contribuição em tudo o que eu vejo...nós não importamos absolutamente um modelo e o colocamos em funcionamento... A essência dele é igual, eu fui estudar isso na ancoragem e fui estudar nos modelos de telejornal. Então tudo o que, às vezes você vê a gente fazendo, de um certo jeito, alguém viu lá (SQUIRRA, 2007).

Para Santana, mesmo que a televisão brasileira tenha partido de uma plataforma semelhante a da tevê americana, ela tem maturidade, ela é muito bem feita e tem qualidade.

Prado afirma que o Brasil não copiou o modelo americano, apenas se inspirou nele e, com toda a sua criatividade, inovou, também, no telejornalismo.

Azenha é categórico ao afirmar que a televisão brasileira copiou, mas que também personalizou: "eu acho que, independente de concordar ou não com isso, ela personalizou um pouquinho, mas da mesma maneira que eu acho que isso tem haver com a cultura brasileira."

Para Malavolta, não se trata de uma cópia, porque a tevê americana é muito ruim, mas ele ressalta que, quando se implantou a televisão no Brasil, se tinha a tevê americana como modelo.

Gomide afirma que o brasileiro não copiou o modelo americano, porque os telejornais dos Estados Unidos tem muitas diferenças dos telejornais daqui:

quando a gente imagina que o cenário do Jornal da Globo possa lembrar um cenário de um telejornal americano, de fato a origem pode ter sido lá, mas se vê que os telejornais brasileiros, hoje, tem uma dinâmica e um ritmo melhor que os telejornais americanos (GOMIDE, 2007).

Pelosi confirma que se não copiou, se inspirou no modelo americano: "a bem da verdade, não só o telejornalismo se inspirou no americano; o rádio, os jornais e as revistas, também. Sem falar de outros setores."

Nascimento coloca que o telejornalismo americano é o melhor do mundo: "eles inventaram a televisão, em primeiro lugar. Foi ali que começou tudo. Então, é natural que seja assim. A tevê Globo se inspirou no modelo americano e as demais, também, isso é inquestionável." 
Para Vizeu, se a gente copiou o modelo americano, numa outra lógica, na lógica do capitalismo, a lógica do mercado:

a lógica do mercado é que embala diversas atividades. Embala o jornalismo, embala a medicina, embala todo o mundo. Essa lógica de mercado foi a lógica de mercado do jornalismo. Isso não quer dizer que o jornalismo não tenha capacidade de trabalhar com esse campo, tencionar e fazer um bom jornalismo com a participação efetiva da sociedade (VIZEU, 2006).

Cardim coloca um ponto de vista, que diz respeito à provável cópia estar vinculada à valorização do profissional: "se fosse cópia dos americanos, muito jornalista na faixa de 50 até 60 anos, até mulher mesmo, e eu me coloco nesse meio, estariam no ar... se fosse mesmo influência americana, o Brasil copiaria as coisas boas deles, que é prestigiar o profissional que tem experiência."

Amorin destaca que o Brasil não copiou, como também está muito ligado no modelo americano até hoje:

eu adoraria que a gente estivesse no modelo europeu, principalmente pra dar mais chance para as mulheres ficarem mais tempo no vídeo, porque isso é um problema americano. Você completa 50 anos e tem que pensar numa estratégia de estar saindo do vídeo, mesmo adorando ficar e ir pra rua e tal.

Fanucchi se reporta aos anos 50 e relata que a influência americana não existia naquele tempo: "de jeito nenhum, não se via nada... o que a gente via na televisão, naquela época, era uma cena de um filme que parecia alguma coisa de televisão."

Para Hoineff, infelizmente, o Brasil copiou mal o telejornalismo americano: "é claro que copiou. Se tivesse copiado bem, era muito bom pra nós. Copiou com jequisse. O telejornalismo americano é um e o telejornalismo brasileiro é um telejornalismo americano acrescido da jequisse brasileira."

Para Poppovic, todo mundo se copiou, em termos de telejornalismo:

eu acho que a televisão americana é um padrão muito bom de jornalismo. Os Estados Unidos é um país democrático, que ensinou a nós, brasileiros, que vivemos muitos anos na ditadura, a ouvir todos os lados, quer dizer, nos Estados Unidos, não existe você fazer uma matéria onde não ouve os vários lados da questão.

Kalil até apresenta outras áreas da televisão em que o Brasil evoluiu, mas em jornalismo não: "em termos de jornalismo, ela é muito ainda quadradinha, o modelo americano". 
Andrade admite a cópia, mas não só dos americanos e não só pelos brasileiros:

todo mundo copiou a televisão americana e, por incrível que pareça, às vezes, a televisão Mexicana, também. A Mexicana copiava mal os americanos, aí o Brasil copiava mal os mexicanos. Então, uma cópia geral. Como dizia o Chacrinha, na televisão, nada se cria, tudo se copia (ANDRADE, 2006).

Por outro lado, existem alguns jornalistas que colocam, antes da influência americana, outras contribuições para a formação do telejornalismo brasileiro, como é, por exemplo, a opinião de Leandro: "na verdade a busca dessa origem, eu acho que há um certo equívoco, porque o telejornalismo é herdeiro do radiojornalismo. Todos os primeiros profissionais que trabalharam em televisão, vinham do rádio". Para ele, a falta de estrutura trouxe para o telejornalismo brasileiro o modelo americano: "a falta de recurso técnico, ou seja, a falta de dinheiro na televisão brasileira importou para o telejornalismo um modelo que não é bem americano, é um talk show". 


\section{Capítulo 4 - Tendências, Desafios e Perspectivas para os telejornalistas brasileiros: do analógico ao Digital.}

\subsection{A formação acadêmica}

A formação acadêmica do profissional especializado em telejornalismo não começou exatamente com a criação do curso de Jornalismo no Brasil. Este, por si só, teve um processo longo e difícil de se concretizar. Antes da formação acadêmica, os primeiros profissionais que trabalharam nas redações de tevê aprendiam na prática do dia-a-dia, ou eram oriundos de emissoras de rádio, conforme já verificamos com os entrevistados, durante esta pesquisa.

O primeiro projeto para a criação de um curso de ensino superior em Jornalismo, no país, foi criado em 1918, através de um congresso organizado pela Associação Brasileira de Imprensa - ABI. Mas, como não passava de um projeto, ficou apenas no sonho dos jornalistas brasileiros da época.

Em 1935, houve uma segunda tentativa de implantar o ensino superior em jornalismo, na Universidade do Distrito Federal. O curso, segundo Mendes, tinha um perfil europeu, concentrando-se em disciplinas como Ciências Sociais e Ética. Com a instituição do Estado Novo, a Universidade foi fechada e a iniciativa frustrada não chegou a diplomar nenhuma turma e nem a funcionar regularmente.

Apesar de o primeiro curso de jornalismo do Brasil ter sido regulamentado em 1943, a primeira Faculdade de Jornalismo só começou a funcionar em 1947, vinculada à Pontifícia Universidade Católica, em parceria com a Fundação Cásper Líbero, em São Paulo. A demora entre a criação e a implantação deveu-se aos entraves burocráticos, pois o ensino de jornalismo, apesar de instituído por decreto, em 1937, não havia sido regulamentado ainda pelo Ministério da Educação. De acordo com o documento elaborado pelo 9ํㅗㅇ Fórum Nacional de Professores de Jornalismo, em 2006, intitulado: Avaliação dos cursos de graduação e o ensino de jornalismo:

Oficialmente, o primeiro curso de jornalismo no país, a ser oferecido pela Faculdade Nacional de Filosofia (universidade do Brasil, no Rio de Janeiro), com a cooperação da $A B I$ e dos sindicados representativos 
de empregados, ocorreu através do Decreto-Lei 5.480, de 13 de maio de 1943. Este curso, entretanto, só começou a funcionar em 1948. ${ }^{77}$

$\mathrm{Na}$ década de 60, haviam em funcionamento no Brasil, 20 cursos de jornalismo. Na década seguinte, este número saltou para 46. O motivo deste aumento foi a regulamentação da profissão, que aconteceu em 1969, quando passou a ser obrigatório o diploma para o exercício da profissão.

O governo americano, através de organismos internacionais, especialmente o Centro Internacional de Estudos Superiores de Jornalismo para a América Latina (Ciespal), influenciou na orientação ideológica dos cursos de Jornalismo. Neste sentido, a América Latina foi contemplada com um centro de formação de professores de jornalismo, na Universidade Central de Quito, no Equador, em 1960.

Para Andrade, a exigência do diploma surgiu em um período em que as escolas sofriam profunda influência deste ambiente internacional:

Com o objetivo de diluir o conteúdo crítico inerente ao Jornalismo em um curso de 'Comunicação Social' que formaria também publicitários, pessoal de relações públicas e cineastas, o Ciespal introduz no Brasil este profissional polivalente, mais tarde conhecido como comunicólogo (ANDRADE, 1999).

A formação em Comunicação Social oferecia ao aluno a possibilidade de trabalhar em qualquer área da comunicação. Foram os chamados polivalentes, ou "faz tudo", conforme o jargão jornalístico. Andrade recorre a Metischi para tentar explicar os objetivos e a função dessa política americanizada implantada pelo Ciespal, na América Latina:

Segundo Meditsch, a política do centro influenciou a regulamentação profissional em diversos países e conseguiu unificar a linguagem acadêmica da área em todo o continente, com a boa desculpa de "facilitar o intercâmbio". Em 1964, o Centro já havia formado, em seus cursos, mais de duzentos professores e diretores de escolas, e os resultados não tardam a aparecer. Conforme relatório do professor americano Raymond Nixon, em 1970 um terço das escolas do continente já haviam trocado a denominação "de jornalismo" por "de comunicação" ou equivalente. Em 1980, este número estava próximo de 85\% (MEDITSCHI, 1999 - Apud ANDRADE).

Um estudo realizado por Koshiyama avalia o ensino de jornalismo na Escola de Comunicações e Artes da Usp, entre 1975 e 1976. A pesquisadora

\footnotetext{
${ }^{77}$ http://www.fnpj.org.br/downloads/relatorio-avaliacao[2006].pdf - acesso em 01 de agosto de
} 2008. 
elabora um histórico a respeito da idéia de que o jornalismo é uma atividade para ser ensinada em escolas superiores. Através de alguns nomes importantes de empresários de comunicação e políticos, foi montada toda a abordagem proposta por ela em favor da formação acadêmica:

Joseph Pulitzer, que patrocinou a criação da primeira escola de jornalismo nos Estados Unidos (...) Também Antonio Gramsci, um dos fundadores do Partido Comunista Italiano, defendia a necessidade de se oferecer uma formação sistemática para os jornalistas, em escolas criadas para essa finalidade. (KOSHIYAMA, 1975)

A pesquisadora confirma que, na cultura brasileira, apesar da necessidade da formação acadêmica ter sido motivo de debates entre empresários e trabalhadores, no final dos anos sessenta, devido à regulamentação da profissão, "a polêmica inicial era sobre a obrigatoriedade da posse de um diploma universitário em jornalismo, para se ter um lugar no mercado de trabalho". Existia a idéia de que isso significava uma reserva de mercado para os diplomados, mas esse fato nunca se concretizou, porque o número de formandos, depois da regulamentação, passou a ser maior do que a demanda do mercado.

De acordo com Pinho, em 1977, o Conselho Federal de Educação distinguiu três fases do ensino em Comunicação Social no Brasil, através do Parecer 1203/77. A primeira foi denominada de clássico-humanista, a segunda de científico-técnica e a terceira como crítico-reflexiva. Na primeira fase:

a) Clássico-humanista, Vai do início dos cursos até a segunda metade da década de 60. Caracteriza-se pela predominância de uma orientação européia, clássica. Restringindo-se quase que exclusivamente ao ensino de jornalismo gráfico, as escolas analisam essa atividade sob os aspectos literário, ético-jurídico e histórico. Não dispondo de equipamento e de laboratórios, os cursos dão pouca ênfase ao treinamento técnico, indispensável ao manejo dos meios de comunicação. Tendem a desaparecer os vestígios dessa fase no ensino de Comunicação Social (MEC/CONSELHO FEDERAL DE EDUCAÇÃO, 1977:44-46 Apud PINHO).

Nesta fase, praticamente não existia 0 ensino institucionalizado de telejornalismo, pois a maioria dos profissionais em atividade, neste período, eram oriundos de emissoras de rádio ou com formação acadêmica em outras áreas. Outro fator que influenciou a falta de especialização do telejornalista foi que a formação que as Faculdades ofereciam estava focada no impresso. Importante citar o caso de alguns entrevistados que iniciaram suas atividades 
em televisão nos anos 60, como Gregório Bacic, Fernando Pacheco Jordão e Luiz Fernando Mercadante, que apesar de carreiras brilhantes, não chegaram a concluir um curso superior. Outros jornalistas, da mesma época, possuem formação acadêmica em outras áreas, como é caso de Fernando Barbosa Lima (Direito), Carlos Alberto Vizeu (Direito), Fábbio Peres (Publicidade), Demétrio Costa (Geografia). Dos anos 60, os dois únicos profissionais entrevistados que possuem formação em Jornalismo são Paulo Roberto Leandro, que é da primeira turma da Eca/USP e Clélia Cardim, que iniciou o curso na Cásper Líbero, de São Paulo, mas se diplomou pela Puc do Rio de Janeiro. Este cenário só confirma a falta de uma especialização, mesmo na academia, para a formação do telejornalista no curso de jornalismo.

$\mathrm{Na}$ segunda fase é possível identificar uma mudança significativa na orientação dos cursos, devido à regulamentação da profissão, à exigência do mercado e à influência americana:

b) Cientifico-técnica: Inicia-se na primeira metade da década de $60 \mathrm{e}$ consolida-se no final da mesma década, legitimada pelo Parecer $631 / 69$, que implantou o currículo em vigor. Caracteriza-se pela introdução nos cursos, de uma orientação calcada no modelo norteamericano de ensino de Comunicação Social. A ênfase recai no tratamento técnico-científico do fenômeno da comunicação. A nível de currículo (sic), são introduzidas matérias que visam ensinar os fundamentos psicológicos, sociológicos e antropológicos da Comunicação Social além das técnicas de pesquisa (entre as quais as análise e conteúdo) de base quantitativa. O modelo utilizado para descrever o processo da Comunicação Social é a proposta original, porém, formalista, do quem diz o que, através de que canal e com que efeitos, de Harold D. Lasswell. Introduz-se no currículo um maior número de disciplinas técnicas. Esse fato, aliado a outro - o recrutamento de professores no mercado de profissionais de Comunicação Social - produz nos cursos um movimento pela aquisição e implantação de laboratórios e equipamentos que permitem melhor treinamento técnico. $O$ ensino assume, então, uma conotação pragmática. Nesta fase, alarga-se o campo de ensino de Comunicação Social. (...) Conservou, no entanto, uma orientação gutemberguiana, conferindo peso excessivo às matérias destinadas à preparação de profissionais para veículos impressos (MEC/CONSELHO FEDERAL DE EDUCAÇÃO, 1977:44-46 Apud PINHO).

Em paralelo a este novo rumo tomado pelos cursos de Jornalismo no país, acontecia a implantação do modelo americano, no telejornalismo brasileiro. Nas universidades, começam a surgir os primeiro professores específicos para a disciplina de telejornalismo.

Um dos primeiros e significativos neste período, foi Walter Sampaio, que também criou o primeiro manual de telejornalismo editado no Brasil, Jornalismo 
Audiovisual, em 1971, pela Editora Vozes, Petrópolis, em co-edição com a Editora da Usp. A pesquisa de mestrado de Rúbia de Oliveira Vasques, intitulada $O$ conhecimento brasileiro sobre telejornalismo - um estudo comparativo dos manuais didáticos mais usados nos cursos de jornalismo, apresentada à Universidade Metodista de São Paulo, em 1999, contemplou uma entrevista com Walter Sampaio. Infelizmente, não foi possível, neste estudo, o contato com o mesmo, porque ele faleceu em 04 de maio de 2002. Por esse motivo, vamos reproduzir informações da entrevista realizada por ela, que relata o período em que ele trabalhou como professor de telejornalismo. Segundo Vasques, Walter Sampaio se aproximou da Universidade de São Paulo, participando das reuniões da comissão que criou o projeto final do curso de Jornalismo da Escola de Comunicações e Artes. No final do projeto, ele foi convidado para ser professor do novo curso, pelo diretor da faculdade, Júlio Garcia Marejón. Ele recusou convite, alegando "nunca ter dado aula na vida." Em 1967, resolveu participar, mas como aluno. Foi o terceiro colocado no primeiro vestibular da Eca: "fui fundador da Eca, não como professor, mas como aluno", declarou ele. Vasques (1999) relatou esse momento histórico:

\begin{abstract}
Quando chegou no terceiro ano do curso de jornalismo surgiram às disciplinas radiojornalismo e telejornalismo, mas a Eca não possuía professor capacitado. As pessoas que se inscreveram não tinham titulação necessária para ministrar aulas. Assim, o professor José Marques de Melo, que na época era chefe de departamento, convidou Walter para ser monitor, e dar aula para seus próprios colegas.
\end{abstract}

A conseqüência deste trabalho desenvolvido por Walter Sampaio, na graduação de jornalismo, foi à elaboração do manual $^{78}$, através de fichas/aulas que seriam ministradas nas disciplinas de radiojornalismo e telejornalismo. Este primeiro manual de telejornalismo foi editado 21 anos depois de ter sido criado o primeiro curso de jornalismo do Brasil. Depois de concluir o curso e ter ministrado aulas para os próprios colegas de turma, Walter Sampaio foi contratado como professor do Departamento de Jornalismo e Editoração da Escola de Comunicações e Artes da USP.

\footnotetext{
${ }^{78}$ Jornalismo Audiovisual, o primeiro manual de telejornalismo já foi referenciado anteriormente no capítulo 2.
} 
A mudança do foco de clássico-humanística para científico-técnica das escolas de comunicação, de acordo com Meditschi, influenciou a implantação do funcionalismo no Brasil:

No caso do ensino de jornalismo, esta "modernização conservadora", como a chamou Florestan Fernandes, ou "modernização reflexa", segundo Darcy Ribeiro, implicou numa ruptura da orientação teórica das escolas, que, até então, centradas numa formação clássicohumanística, com ênfase nos estudos éticos, jurídicos, filosóficos e literários. Esta orientação, por influência do Ciespal, será rejeitada por "não-científica", e substituída pelas disciplinas valorizadas pelo funcionalismo norte-americano (MEDITSCH, 1999).

Koshiyama (1975) relata, no seu trabalho, um tópico a respeito do ensino de jornalismo durante o período da ditadura. De acordo com ela, na década de 70 , os estudantes vivenciaram as piores condições objetivas para 0 trabalho:

Não por opção de alunos e professores. Mas por imposição das conjunturas históricas: fechamento político, precariedade absoluta de meios de execução de um trabalho jornalístico contínuo e periódico, impotência da maioria do corpo docente foram condições que marcaram as atividades de ensino de jornalismo na Eca/USP (KOSHIYAMA, 1975).

Outros fatos importantes revelados por Koshiyama, relativos ao período da ditadura, foram a prisão do professor Jair Borin e a descontratação de alguns professores, como José Marques de Melo ${ }^{79}$, Thomas Jorge Farkas e José Freitas Nobre, do Departamento de Jornalismo e Editoração. "Foram apenas sintomas do processo repressivo político, só revertido com a anistia política, nos anos 80." A ditadura também proporcionou a omissão de alguns registros, que foram apagados do Relatório Anual de Atividades do Departamento de Jornalismo e Editoração da Eca, no ano de 1975. Como foi o que aconteceu com o jornalista Wladimir Herzog, que não figurava na lista de professores que atuaram naquele ano letivo:

Herzog lecionou telejornalismo juntamente com a professora Gisela Ortriwano, no segundo semestre do ano, até a semana em que morreu nas dependências do DOI-CODI de São Paulo (...) Herzog aguardava a publicação do seu contrato de trabalho no Diário oficial, mas trabalhou de fato, como alguns outros docentes em situação funcional idêntica. Todas as pessoas do corpo docente (efetivos, contratados, à espera de

\footnotetext{
${ }^{79}$ José Marques de Melo foi reintegrado ao corpo docente da Universidade de São Paulo em decorrência da Lei de Anistia Política e retoma as atividades docentes e de pesquisa no Departamento de Jornalismo e Editoração da Eca/USP.
} 
contratos e voluntários), exceto Herzog, figuraram no Relatório (KOSHYIAMA, 1975)

Na terceira e última fase, é possível identificar uma evolução, com o início da pesquisa em Comunicação Social no Brasil:

c) Crítico-reflexiva: Depois do acelerado crescimento da década anterior e do começo da atual, o sistema de ensino de Comunicação Social entra num ritmo de crescimento moderado. Embora ainda sofram as conseqüências da expansão explosiva do período anterior, como falta professores qualificados, desorganização administrativa, baixo nível de ensino e deficiência de equipamentos e laboratórios, as escolas começam a adquirir as condições de tranqüilidade necessárias ao desenvolvimento da reflexão. Ao lado da preocupação com a eficiência ainda não atingida do treinamento profissional, desenvolvese, com efeito, o nível de reflexão teórica. Tendo a Comunicação Social perdido o caráter de novidade, ou de moda, pode-se agora, graças à experiência adquirida pelas escolas e pelo surgimento dos primeiro cursos de pós-graduação em nível de mestrado, avaliar o seu correto significado e importância dentro da sociedade. É forçoso reconhecer tratar-se de tendência que irá acentuar nos próximos anos. Mas, a rigor, não se pode falar em preocupação teórica para grande parte do sistema de ensino, que continua a consumir suas melhores energias no esforço de aquisição de condições mínimas de funcionamento (MEC/CONSELHO FEDERAL DE EDUCAÇÃO, 1977:44-46 Apud $\mathrm{PINHO})$.

De encontro com esse momento propício para o desenvolvimento do ensino e da pesquisa em Comunicação, surge o primeiro doutor na área. José Marques de Melo foi o primeiro brasileiro a receber o título de doutor em Comunicação Social - Jornalismo, em 1973. A Tese denominada Fatores sócio-culturais que retardam a imprensa no Brasil foi orientada por Rolando Morel Pinto, na Escola de Comunicações e Artes da USP. Pode-se dizer que Marques de Melo foi um dos principais responsáveis pelo desenvolvimento da pesquisa no Brasil, pois ao longo de sua carreira, ele já orientou 33 teses de doutorado, 73 dissertações de mestrado, também publicou113 artigos em periódicos, 13 artigos em jornais, 142 artigos em revistas, 28 livros, 34 opúsculos, 83 coletâneas, 73 capítulos de livros, 22 capítulos de anais e 61 prefácios e posfáceos. Também recebeu inúmeros prêmios, títulos e menções honrosas. É uma referência no ensino e pesquisa em jornalismo; tendo desenvolvido um dos principais pilares do jornalismo através das teorias da Opinião e da Informação, entre outras.

Nesta fase, de acordo com Mendes, também foram criados e consolidados os cursos oferecidos pelas próprias empresas de comunicação, 
como o Estado de S. Paulo, Rede Globo, Folha de S. Paulo e Editora Abril. Os cursos oferecidos pelas empresas jornalísticas tratam-se de estágios e treinamentos oferecidos aos estudantes nos dois últimos anos da faculdade, devido à defasagem existente entre o conhecimento oferecido pelo bacharelado e as exigências do mercado.

Os cursos universitários mal aparelhados não acompanharam a evolução tecnológica que se processou dentro das redações. Os laboratórios das escolas ainda usavam máquinas de escrever quando a comunicação avançava para a informatização e a multimídia (MENDES, 1999 )

Esse descompasso entre a academia e o mercado acabou levando algumas empresas jornalísticas a combaterem sistematicamente a obrigatoriedade do diploma. "A resposta dos jornalistas à posição adotada pelo empresariado do setor tem sido campanhas permanentes a favor do diploma", conclui Mendes.

O Parecer do Conselho Federal de Educação também apresenta alguns números importantes a respeito dos cursos de graduação em Jornalismo no Brasil, como os dados fornecidos pelo Censo de Ensino Superior, realizado em 2004, pois acredita-se que pouco se tenha mudado até o momento, devido ao movimento de estagnação do crescimento das instituições de ensino superior no país, na década atual. Naquele momento, o Brasil possuía 477 cursos de graduação em Jornalismo sendo que deste total, 36 funcionavam em instituições de ensino federais, 20 em instituições estaduais, 17 em instituições municipais, 262 em instituições particulares e 142 em instituições de cunho comunitário ou filantrópico. Estes dados apontam um crescimento ascendente, nos mais de 60 anos da criação do curso de jornalismo, até os dias atuais.

Ainda nos anos 80 e 90, o papel das escolas de Comunicação se apresentou adequado para a formação de jornalistas profissionais, mas isso não impediu a continuidade da divergência entre sindicato e empresários sobre a possibilidade de se obter, apenas nas escolas de jornalismo, a habilitação para atuar nas empresas jornalísticas. 
As escolas de comunicação cresceram, se modernizaram, mas não conseguem acompanhar a evolução tecnológica imposta pelo mercado de trabalho, que está em constante evolução. Koshiyama (1975) apresenta no seu estudo uma visão realista dessa questão, que mais adiante vai se transformar num grande problema:

Reconhecer limitações impostas pela conjuntura, assumidas segundo nossas circunstâncias e precariedade, é um caminho para se debater o processo de aprendizagem. A experiência histórica comprova o caráter permanente do ensino, visto enquanto atividade cultural e política. Reaviva, em decorrência, a questão sobre os aspectos imprescindíveis para serem desenvolvidos nas salas de aulas, em cursos que se pretendem profissionalizantes.

Dentre os entrevistados, quatro deles acabaram se tornando, também, professores de telejornalismo: Sebastião Carlos Squirra, Laurindo Leal Filho, Alfredo Vizeu e José Carlos Aronchi de Souza. Todos eles, cada um a seu modo, desenvolveram técnicas e metodologias diferenciadas, para possibilitar aos alunos uma boa formação e conhecimento em telejornalismo. Squirra sempre focou boa parte de seu trabalho didático na prática cotidiana das rotinas de produção de um telejornal e de outros produtos informativos, como documentários e grandes reportagens. "Os alunos faziam um telejornal diário", relatou ele. Leal Filho, apesar de focar o ensino na parte prática, também focava na análise. "Eu prefiro discutir, e discutia mesmo a análise crítica dos produtos", informou ele. Vizeu aproveita a oportunidade da academia para "uma relação dialética entre teoria e prática" e utiliza a metodologia da observação participante. Aronchi ressalta a importância de juntar a teoria com a prática, para lecionar:

desde o início, até a atualidade, eu sempre tive um pé no mercado e um pé dentro da academia, sempre procurei fazer isso - ensinar aquilo que eu estava fazendo, apresentar aos alunos aquilo que estou desenvolvendo no mercado ou então em alguma atividade profissional.

Atualmente, é possível acrescentar mais uma fase ao processo evolutivo do ensino de jornalismo no país. A quarta fase, que poderia ser inicialmente denominada de técnico-digital. Este período tem início no final dos anos 90 e 
início do século XXI, até os dias atuais. As preocupações com o diploma caminham para um período de desregulamentação da profissão, mas que será mais bem observado no próximo tópico. Por hora, vamos tratar das exigências impostas aos jornalistas e, principalmente, aos telejornalistas, relativas à implantação da tevê digital.

A observação dos rumos que a profissão de telejornalista vai tomar nos próximos anos está diretamente ligada com a evolução tecnológica, pelas quais as emissoras estão passando neste percurso, que se iniciou depois da escolha do modelo japonês para a tevê digital brasileira (2006), e deve durar até 2016. O processo de digitalização implica numa ampliação dos conhecimentos dos profissionais, para poder lidar com a nova tecnologia.

Algumas emissoras já vêm fazendo experiências com seus equipamentos, conforme ocorreu com a Rede TV, que foi a primeira emissora totalmente digital do país. Com isso, a rotina da redação ganhou um ritmo mais ágil, e passou a exigir dos profissionais uma dinamização e um domínio maior dos equipamentos informatizados, como é caso do teleprompter, que passou a ser operado pelo apresentador, das fitas, que deixaram de existir, e das imagens, que são editadas a partir do HD da própria câmera. Outra novidade foi a eliminação do script impresso. Agora, só existe o script virtual, nas telas dos computadores espalhados por todos os setores, desde a redação, até o suwiter. Só resta saber como é que as faculdades de jornalismo vão preparar os estudantes para lidar com estas novidades tecnológicas?

No decorrer dos anos, a questão do ensino em jornalismo formou uma legião de entidades e instituições, além da FENAJ e do Sindicato dos jornalistas, que não medem esforços para que todos que atuam no ensino e na pesquisa possam ter qualidade e atendam às necessidades do mercado de trabalho. Entre as entidades, estão a Associação Brasileira de Escolas de Comunicação (ABECOM), a Associação Nacional de Programas de PósGraduação em Comunicação (COMPÓS), a Executiva Nacional dos Estudantes de Comunicação (ENECOS), a Sociedade Brasileira de estudos Interdisciplinares da Comunicação (INTERCOM) e o Fórum Nacional de Professores de Jornalismo (FNPJ). 
De acordo com FENAJ, só a formação através de um curso específico especializado, pode tornar consistente a abordagem da multiplicidade dos aspectos filosóficos, teóricos, culturais e técnicos envolvidos na formação dos jornalistas, bem como propiciar que, através da reflexão acadêmica e da prática política e técnica, sejam equacionadas as demandas da sociedade em relação à atuação destes profissionais. Para a direção da FENAJ, a formação dos jornalistas deve ser concebida a partir da percepção do seu papel singular de produtor de conhecimento e de cultura, através de uma atividade profissional especializada na formulação, seleção, estruturação e disponibilização de informações que são usadas pelos indivíduos, para perceberem e situarem-se diante da realidade. Para que isso ocorra, a entidade estabelece que a formação do jornalista deva considerar:

1) o interesse público na geração de conhecimento válido sobre os fenômenos que envolvem $o$ exercício do Jornalismo e da especificidade que o distingue do conjunto da área das comunicações; 2) a necessidade de pesquisa e experimentação de teorias e técnicas relacionadas com as linguagens e práticas aplicáveis ao exercício do Jornalismo ${ }^{80}$

A formação profissional do jornalista também deve alcançar compreensão e identificação, com dois importantes eixos:

1) dos fundamentos éticos prescritos para a conduta dos jornalistas profissionais; 2) da atitude de cidadania adequada ao exercício profissional dos jornalistas, a partir do reconhecimento das expectativas e necessidades da sociedade em relação ao seu papel social e ao produto da sua atividade; 3 ) do inter-relacionamento entre as funções profissionais dos jornalistas com as demais funções profissionais ou empresariais existentes na área das comunicações. ${ }^{81}$

Para o ensino específico de telejornalismo, Vasques propõe, em seu trabalho, que o aprendizado, para ser completo, necessita tanto da prática quanto da teoria. Ela analisa, através de três obras ${ }^{82}$, que a sistematização do conhecimento telejornalístico teve por base a vida prática de seus autores, mas que só contato com a vida acadêmica, fez com que eles percebessem a

${ }^{80}$ FENAJ, Disponível em: http://www.fenaj.org.br/arquivos/artigosergiomurilloportugues.doc Acesso em 03 de agosto de 2008.

81 FENAJ Disponível em: http://www.fenaj.org.br/arquivos/artigosergiomurilloportugues.doc Acesso em 03 de agosto de 2008.

82 Jornalismo Audiovisual (Walter Sampaio), O Texto na TV (Vera Íris Paternostro) e Aprender Telejornalismo (Sebastião Carlos Squirra). 
necessidade e a importância dessa sistematização. Por fim, a autora conclui que as três obras são complementares. Isso indica para o professor de telejornalismo deverá pesquisar sempre mais de uma obra, para proporcionar um aprendizado completo.

Ainda sobre a formação acadêmica, Marques de Melo, em 2 de março de 2007, proferiu sessão inaugural das II Jornadas Internacionais de Jornalismo, na Universidade do Porto, em Portugal ${ }^{83}$, onde tematizou a necessidade de Reinventar o ensino de jornalismo: desafio inadiável do século $X X I$. Ele responde ao questionamento a respeito da utilidade do estudo de jornalismo nos dias de hoje, com a constatação de que existe uma crise de identidade, que precisa ser defendida na especificidade, como campo acadêmico. A proposta de reinvenção para o ensino de jornalismo, de acordo com ele, precisa superar duas distorções congênitas:

1) Romper a tradição gutembergiana que nos tem mantido prisioneiros, dentro de estruturas tecnologicamente anacrônicas que ainda governam a lógica dos processos de ensino-aprendizagem. (...) 2) Ultrapassar a caricatura balzaquiana que nos tem induzido a privilegiar a formação aristocrática de jornalistas comprometidos com os interesses das elites cultas ou medianamente educadas (MARQUES DE MELO, 2007).

No item 1, ele propõe um foco maior dos cursos para as novas tecnologias digitais, com o objetivo de produzir conteúdo para a maioria da população excluída da formação educacional, mas com capacidade de assistir e ouvir o conteúdo necessário para a sua informação e socialização. Já no item 2, a proposta é a utilização de táticas motivadoras sintonizadas com o repertório popular e acessível e não uma cultura erudita que persiste no domínio. Essas novas propostas de Marques de Melo vem de encontro com algumas idéias apresentadas durante esta pesquisa, a respeito do profissional de telejornalismo.

\subsection{A regulamentação profissional}

\footnotetext{
${ }^{83}$ O texto também foi reproduzido pela Revista Líbero da Fundação Cásper Líbero, v. 19, p.916, 2007.
} 
A regulamentação da profissão de jornalista (que inclui o telejornalismo como uma função jornalística), conforme já mencionado, aconteceu em 17 de outubro de 1969, através decreto-lei 972.

Ao relacionar o período em que a profissão de jornalista foi regulamentada, em plena ditadura militar (1964-1985), é possível identificar algumas imperfeições inerentes à postura ideológica do regime. Naquele momento, o Congresso Nacional estava fechado e o país sendo governado por uma junta formada pelos ministros das forças armadas Aurélio de Lima Tavares, do Exército, Augusto Rademaker, da Marinha e Márcio Sousa e Mello, da Aeronáutica.

Em 13 de março de 1979, os termos da lei foram revistos pelo Decreto №. 83.284, mas sem sofrer modificações em seus pontos fundamentais. A profissão de jornalista é aquela que compreende, privativamente, o exercício habitual e remunerado das seguintes atividades:

I - redação, condensação, titulação, interpretação, correção ou coordenação de matéria a ser divulgada, contenha ou não comentário;

II - comentário ou crônica, por meio de quaisquer veículos de comunicação;

III - entrevista, inquérito ou reportagem, escrita ou falada;

IV - planejamento, organização, direção e eventual execução de serviços técnicos de jornalismo, como os de arquivo, ilustração ou distribuição gráfica de matéria a ser divulgada;

V - planejamento, organização e administração técnica dos serviços de que trata o item I;

$\mathrm{VI}$ - ensino de técnicas de jornalismo;

VII - coleta de notícias ou informações e seu preparo para divulgação;

VIII - revisão de originais de matéria jornalística, com vistas à correção redacional e à adequação da linguagem;

IX - organização e conservação de arquivo jornalístico e pesquisa dos respectivos dados, para elaboração de notícias;

$X$ - execução da distribuição gráfica de texto, fotografia ou ilustração de caráter jornalístico, para fins de divulgação;

$X I$ - execução de desenhos artísticos ou técnicos de caráter jornalístico, para fins de divulgação. 
O Decreto exige, em seu Artigo 4ํㅡㄴ, III, diploma de curso de nível superior de jornalismo ou de comunicação social, habilitação jornalismo, fornecido por estabelecimento de ensino reconhecido na forma da lei, para as funções relacionadas nos itens I a VII do art. 11, quais sejam:

I - Redator: aquele que, além das incumbências de redação comum, tem o encargo de redigir editoriais, crônicas ou comentários;

II - Noticiarista: aquele que tem o encargo de redigir matérias de caráter informativo, desprovidas de apreciações ou comentários, preparando-as ou redigindo-as para divulgação;

Decreto no. 83.284, de 13 de março de 1979.

III - Repórter: aquele que cumpre a determinação de colher notícias ou informações, preparando ou redigindo matéria para divulgação;

IV - Repórter de Setor: aquele que tem o encargo de colher notícias ou informações sobre assuntos predeterminados, preparando-as ou redigindo-as para divulgação;

V - Rádio Repórter: aquele a quem cabe a difusão oral de acontecimento ou entrevista pelo rádio ou pela televisão, no instante ou no local em que ocorram, assim como o comentário ou crônica, pelos mesmos veículos;

VI - Arquivista-Pesquisador: aquele que tem a incumbência de organizar e conservar cultural e tecnicamente 0 arquivo redatorial, procedendo à pesquisa dos respectivos dados para elaboração de notícias;

VII - Revisor: aquele que tem o encargo de rever as provas tipográficas de matéria jornalística.

Podem exercer profissões jornalísticas, sem necessidade de diploma específico, desde que com registro prévio no órgão regional do Ministério do Trabalho - sendo vedado o exercício das funções anteriores --, aqueles que pratiquem as seguintes atividades:

VIII - llustrador: aquele que tem a seu cargo criar ou executar desenhos artísticos ou técnicos de caráter jornalístico;

IX - Repórter Fotográfico: aquele a quem cabe registrar fotograficamente quaisquer fatos ou assuntos de interesse jornalístico;

$X$ - Repórter Cinematográfico: aquele a quem cabe registrar cinematograficamente quaisquer fatos ou assuntos de interesse jornalístico; 
$X I$ - Diagramador: aquele a quem compete planejar e executar a distribuição gráfica de matérias, fotografias ou ilustrações de caráter jornalístico, para fins de publicação. ${ }^{84}$

Existem muitas especulações a respeito do fato de o governo militar ter admitido a exigência do diploma para o exercício da profissão. Alguns afirmam que isso poderia funcionar como uma forma de controle, mas o que acabou acontecendo foi o contrário, pois as universidades formavam profissionais altamente críticos e, na sua maioria, contrários ao regime e dispostos a defender seus pontos de vistas.

A exigência legal do diploma teve ao longo da década de 70 alguns marcos históricos do debate, porque a quantidade de jornalistas formados tornou-se maior que o mercado de trabalho conseguia absorver. Esta situação gerou um clima de tensão entre jornalistas e patrões, devido à diferença de perfil do profissional oriundo das universidades, menos disciplinados e mais realistas, frente às condições de liberdade de imprensa. $O$ ponto mais grave deste conflito aconteceu em 1979, devido a uma greve realizada pelos jornalistas de São Paulo. Para Nunes, cerca de $90 \%$ da categoria cruzou os braços, durante 5 dias, para exigir dos patrões um aumento de $15 \%$. Isto poderia indicar que o movimento foi plenamente vitorioso, mas, na realidade, não foi, por vários motivos: 1) mesmo com a greve, os jornais continuaram circulando normalmente; 2) o movimento foi deflagrado no meio do ano, fora da data base da categoria (dezembro) e, por isso, não teria nenhum respaldo da legislação; e 3) a pretensão de reconhecimento dos Conselhos de Redação desembocou a greve para um caráter político. Alguns jornais, como o Jornal da Tarde, deram manchetes sobre a greve em suas edições e inscrições em muros, feitas pelos próprios grevistas, apareceram no dia seguinte, com certa ironia: "não comprem jornais/ jornalistas em greve" (NUNES, 1981; 89-93).

Depois disso, nos anos 80, passou a existir um movimento empresarial, liderado pela Folha de São Paulo, em prol da desregulamentação do diploma, através de algumas ações veladas e sutis, como a utilização de colaboradores e colunistas especializados dentro das redações.

\footnotetext{
${ }^{84}$ Disponívem em: http://www.fnpj.org.br/downloads/relatorio-avaliacao[2006].pdf - acesso em 02 de agosto de 2008.
} 
Este movimento pela desregulamentação da profissão tomou vulto em 17 de outubro de 2001, quando a 16ำ Vara Cível da Justiça Federal de São Paulo - 3o Região recebeu uma Ação Pública, com Pedido de Tutela Antecipada, de iniciativa do Ministério Público Federal, contra o Governo Federal, onde é contestada a exigência do diploma de jornalismo para o exercício da profissão. Logo depois, em 23 de outubro do mesmo ano, uma liminar da juíza federal substituta Carla Abrantkoski Rister suspende a obrigatoriedade da exigência do diploma de jornalismo para a obtenção do registro profissional. Mesmo provisória, a liminar obrigou o Ministério do Trabalho a conceder registros de jornalista a qualquer pessoa que solicitasse, em caráter precário.

Várias tentativas de suspender a liminar que desregulamentou a profissão de jornalistas foram feitas pelo Sindicato dos Jornalistas de São Paulo e pela FENAJ (Federação Nacional dos Jornalistas). A primeira aconteceu em 22 de novembro de 2001, através de um pedido de agravo de instrumento, com efeito suspensivo, contra a liminar concedida pela juíza Carla Rister. Mas, o juiz Manoel Álvares do Tribunal Regional Federal, que foi convocado para avaliar o recurso, manifestou-se pela sua manutenção. $O$ governo federal, réu na ação, através da Advocacia Geral da União (AGU), também entrou com recurso contra a liminar.

Depois de 15 meses da concessão da liminar, em 10 de janeiro de 2003, a sentença em primeira instância confirma a mesma, dispensando a exigência do diploma para o exercício profissional de jornalista. O Sindicato dos Jornalistas de São Paulo e a FENAJ reagem à decisão e encaminham um novo recurso, desta vez, contra a sentença de primeira instância da juíza federal Carla Rister.

Em 23 de julho de 2003, aparece uma luz no fim do túnel para os jornalistas diplomados, pois a apelação da FENAJ e do Sindicato dos Jornalistas de São Paulo é acatada pela desembargadora federal Alda Basto, do TRF 3 Região, que dispensava a exigência do diploma para o exercício da profissão. Mas, como não se tratava de uma decisão final, em 02 de dezembro de 2003 o juiz federal convocado, Manoel Álvares, reconsiderou a decisão da desembargadora Alda Basto e confirma, mais uma vez, a sentença de primeira instância da juíza substituta Carla Rister. 
Com isso, o processo está, desde dezembro de 2003, no TRF - $3^{\circ}$ Região. Deve ocorrer uma análise do recurso da FENAJ e do Sindicato dos Jornalistas de São Paulo. A avaliação do recurso deverá ser feita por uma turma de desembargadores do Tribunal, composta por 3 juízes, e ainda, caberá, depois disso, recurso de ambas as partes, em instâncias superiores, até chegar ao STF, onde a sentença será definitiva.

Em novembro de 2006, o ministro do Supremo Tribunal (STF), Gilmar Mendes, deferiu medida cautelar que mantém o exercício de atividade jornalística aos que atuam na profissão, independentemente de diploma de curso superior na área. A decisão foi tomada na Ação cautelar proposta pela Procuradoria Geral da República.

Já o Superior Tribunal de Justiça (STJ) reconheceu, no dia 8 de novembro de 2006, por unanimidade, a obrigatoriedade de diploma em nível superior em comunicação social, com habilitação em jornalismo, para o exercício da profissão. Segundo nota divulgada no site da FENAJ, a decisão seguiu orientação do Tribunal Regional Federal 3ำ Região (TRF/SP), que em outubro de 2005, declarou absoluta constitucionalidade da exigência do diploma. Como essa decisão recebeu um Recurso Extraordinário, que questiona a regulamentação profissional da categoria, o presidente do Supremo Tribunal Federal (STF), ministro Gilmar Mendes, declarou que o novo julgamento deverá ocorrer no segundo semestre de 2008. Só assim será finalizada definitivamente esta questão.

Durante o período da desregulamentação do diploma, de 2001 a 2005, foram concedidos mais de 13 mil registros profissionais precários, para pessoas não formadas em jornalismo, no país.

Fortes e Albuquerque analisaram 0 debate acerca da desregulamentação da profissão de jornalista no Brasil, levando em conta a negociação dos profissionais da categoria. Segundo eles: "A questão não se limita ao posicionamento - contra ou a favor - com relação à obrigatoriedade do diploma; o debate mostrou claramente o quanto as visões a respeito do que é e deve ser o jornalismo são conflitantes, múltiplas e, em alguns casos, diametralmente opostas."

Segundo a FENAJ, o divórcio entre a teoria e prática trouxe profundas conseqüências, contribuindo para ataques sistemáticos do empresariado do 
setor contra os cursos e a regulamentação profissional. (http://www.fenaj.org.br/arquivos/artigosergiomurilloportugues.doc - acesso em 17 de outubro de 2008)

\subsection{Os impactos tecnológicos no exercício da profissão}

O profissional de jornalismo que exerce a função de telejornalista, ao longo de todo o seu processo de formação, desde 1950, acompanhou uma série de impactos tecnológicos até os dias de hoje. Dentre eles, alguns dos mais importantes estão diretamente relacionados com o seu cotidiano. 0 telejornalista saiu da máquina de escrever e passou para computador, saiu de câmeras de cinema pesadas, com o uso de filme, passou pelas fitas e caminha para a captação digital, com mais definição e, ainda, vai enfrentar o desafio da interatividade. Ele também saiu do preto e branco e passou a produzir imagens em cores. As transmissões televisivas, que antes repercutiam através de antenas e microondas, as notícias publicadas pela manhã, nos jornais impressos, hoje são transmitidas, via satélite, antes de serem publicadas pelos jornais. Todas estas inovações e mudanças tecnológicas ocorridas mostraram que o telejornalista precisa ser flexível, enfrentar novos desafios sempre, e estar preparado para mudanças.

O profissional do telejornalismo sofrerá nos próximos 10 anos - final da implantação da tevê digital no país - uma mudança circunstancial no seu perfil e no seu modo de trabalho. Algumas mudanças no perfil estão ligadas à exigência do domínio de novas tecnologias. Para o jornalista Fábbio Peres (2006), o futuro profissional do telejornalismo ainda é uma incógnita, porque:

O noticiário hoje está fundindo um pouco. O telejornalismo foi uma fusão do rádio com o cinema e agora temos a internet, que não tem uma linguagem igual a da televisão e tem, ainda, a interatividade. Existem dois aspectos que diferem radicalmente o telejornalismo e o noticiário da internet, que são os seguintes: quem comanda o telejornal é o editor-chefe e quem comanda o noticiário da internet é quem está recebendo. Então, o agente receptor é importantíssimo e o produtor de conteúdo da internet não tem autoridade sobre o receptor e, ele sim, tem autoridade sobre o produtor (PERES, 2006).

Esta constatação de Peres dá indícios de que o desafio da interatividade, dentro do telejornalismo, pode mudar radicalmente o modus operandi do 
telejornalista. A perspectiva da interatividade, com a possibilidade do receptor intervir e direcionar o noticiário, vai exigir ainda mais flexibilidade e agilidade do profissional de telejornalismo.

A profissão de telejornalista tem características muito peculiares, como o trabalho em equipe, no estilo fordista, porque ninguém consegue fazer um telejornal sozinho. É preciso de toda uma equipe, que inclui técnicos e jornalistas, onde cada um faz a sua etapa. Com o exercício diário do telejornalista, é possível experimentar a divisão do trabalho em equipe, mas o que vem acontecendo nos últimos tempos é uma mudança neste perfil, ou pelo menos uma alteração. Tomando, como exemplo, o programa Profissão Repórter, comandado pelo jornalista Caco Barcellos, onde as duplas de novos profissionais saem em conjunto e se revezam entre as funções de repórter e cinegrafista. É possível observar, também, a presença de outro cinegrafista, que faz imagens dos bastidores do trabalho (making off). Este fato revela que, além das funções ditas intelectuais, o telejornalista já está convocado a exercer funções técnicas, também. Além da utilização de câmeras, os novos profissionais estão convocados, também, a operar ilhas de edição não-lineares, na hora de editar a reportagem. Essa mudança pode inverter o processo em equipe, com a divisão do trabalho, para um único profissional, exercendo várias funções, ou seja, podemos voltar aos primórdios da profissão, onde não havia a divisão do trabalho em funções.

Nos anos 60, para Leandro, que foi repórter, o maior problema era a limitação de ordem técnica que existia para o telejornalista. "Quando eu entrei na Tupi, a ferramenta que se tinha para trabalhar, fazendo reportagem em televisão, era uma câmera Barry Hawk $16 \mathrm{~mm}$, com filme mudo, preto e branco, negativo, virava positivo, sendo projetado (...) você tinha que entrevistar, em no máximo três minutos. Isso significa uma limitação." Segundo ele, o trabalho do repórter era muito calcado na produtividade, porque era tudo muito caro, então não podia sair com um rolinho de filme de 100 pés, que dava três minutos de tempo útil e voltar com um minuto apenas, tinha que aproveitar em $100 \%$ a película, porque depois que queimava não tinha como reaproveitar.

No final dos anos 60 e início dos anos 70, de acordo com Peres, as chegadas da câmera e da ilha de edição contribuíram para o surgimento do repórter profissional. "Basicamente, a tecnologia favoreceu a reportagem. Hoje 
você tem equipamento de câmera e de edição, você pode sincronizar o que está dizendo com as imagens. Uma revolução que ajudou muito o aparecimento do repórter profissional. "A reportagem começou a ser aperfeiçoada neste período, e esse novo profissional da reportagem começou a se profissionalizar e não ser mais apenas uma testemunha no local onde estava ocorrendo algum fato.

Nos anos 70, tomando como exemplo o Globo Repórter, existia uma autoria maior nos filmes produzidos pelos cineastas, e a própria produção em filme dava um caráter mais artesanal para o produto final. Com a chegada do equipamento Umatic, os cineastas foram, aos poucos, sendo banidos do programa. Os repórteres foram tomando o lugar dos cineastas e a produção autoral passou a ser coletiva, em série, como se fosse uma indústria de produção. De acordo com Coutinho, "os cineastas eram contratados pra fazer aquilo só. Isso acabou. Gente de cinema era convidada pra fazer programa. Hoje quem faz são os funcionários." Para Jordão, que coordenou a sucursal paulista, o Globo Repórter dessa fase era cinematográfico. "Era muito influenciado pelo documentário de cinema." Ele trouxe a inspiração de período anterior, quando esteve trabalhando na BBC, de Londres.

O cineasta João Batista de Andrade, que chegou a ser contratado durante vários anos pela tevê Globo, na fase dos cineastas no programa, recorda a saída do grupo, para dar espaço aos repórteres da casa:

\footnotetext{
ficou uma farsa, por exemplo, um dos primeiros programas feitos por esse pessoal é um sobre o Pantanal (...) onde o repórter saia à noite com o barco e dizia:'nós vamos agora tentar flagrar os coureiros, eles são perigosos, nós estamos aqui com um guia', de repente tem um plano em que aparece a canoa chegando na ilha. Aí eu pergunto: onde é que estava a câmera? Junto dos perigosos coureiros. Essa é a diferença (ANDRADE, 2007).
}

Leal Filho recorda do trabalho do editor de texto, que tinha que usar um equipamento de cinema - a moviola, para poder editar as matérias:

não era nada ao vivo, era tudo filmado. Na verdade, eram dois offs. Era
o off de voz e o off de imagem, em dois equipamentos diferentes. E aí,
o telecine dois tinha que terminar um pouquinho antes do telecine um,
antes de terminar a fala do repórter, porque, aí, ele voltava e terminava
a imagem e ele voltava e encerrava a matéria.

É difícil até imaginar uma situação dessa nos dias de hoje, com a velocidade que é necessária para se exibir um telejornal, ao vivo. 
Soares, que começou a trabalhar em telejornalismo no final dos anos 80 , recorda as condições tecnologicas da época: "não existia telefone celular, fax e computador na redação. Nós escrevíamos na máquina de escrever, rodávamos o espelho na máquina de escrever ou no mimeógrafo e falávamos com os carros na rua, por rádio freqüência." Do final dos anos 80 até os dias atuais, Soares acompanhou uma grande mudança tecnológica dentro da televisão, que alterou todo o processo do telejornalismo:

se por um lado a tecnologia avançou extraordinariamente, mudou o jeito de produzir televisão, de operar televisão. Passamos do analógico pro digital. Do ponto de vista do conteúdo, do ponto de vista das preocupações éticas, morais, eu acho que não só nós continuamos diante dos mesmos desafios, como eles se tornaram mais importantes (SOARES, 2008).

O desenvolvimento tecnológico, para Aronchi, ajudou a desenvolver também o conteúdo da informação no telejornalismo:

esse desenvolvimento tecnológico é muito importante ser compreendido, porque, com ele, também se consegue desenvolver o conteúdo com o qual se está trabalhando. De acordo com o uso que se faz dessa tecnologia, se consegue desenvolver novos conteúdos e novos olhares (ARONCHI, 2008).

Para Aronchi, a tecnologia é benéfica, porque contribui para o aperfeiçoamento do conteúdo, ou seja, o que se pode observar é que as novas tecnologias além de agilizarem o processo de produção, contribuem, também, para a melhoria dos conteúdos. Se observarmos desde a implantação da televisão até os dias de hoje, é possível perceber que os conteúdos estão cada vez melhores, mais organizados e mais apurados.

Para Vizeu, além de toda a evolução tecnológica, nos anos 80 , o que ocorreu foi a exigência de uma qualificação superior. "Naquela época, você tinha aí os profissionais que podiam vir de uma prática, e com o tempo se exige cada vez mais alguém que tenha condições de pensar do ponto de vista do jornalismo." Isso corrobora, também, com a idéia de que o profissional de telejornalismo venha para o campo profissional, com melhores condições intelectuais, porque isso vai proporcionar, também, melhores condições de lidar com as novas tecnologias, mesmo com a academia andando em descompasso com o mercado. 
Nascimento atribui à automação da redação, as facilidades proporcionadas ao processo de edição e de fechamento do telejornal. "A partir do momento que a gente passou a ter computador na redação, onde você controla toda a sua edição, toda a sua produção, através da tela do computador, isso te deu uma agilidade extraordinária." Ele também se recorda da época em que começou no telejornalismo, como a produção de notícia em televisão era uma operação complicada:

do VT pro Umatic, onde o cara tinha que carregar uma câmera de 15 quilos, com um gravador de oito quilos. Tinham que ser cinco pessoas. Tinha um cinegrafista, um repórter, um operador de VT, que era, também, operador de vídeo, um operador de áudio e um auxiliar que segurava o pau de luz. Não podia ser diferente. Depois, ainda tinha que trazer a matéria para a redação e editar antes de exibir. (NASCIMENTO, 2006)

Algumas outras evoluções, que não podem ser chamadas de tecnológicas impactaram o profissional de telejornalismo de uma forma positiva, a partir dos anos 80. A primeira delas foi a introdução do profissional de fonoaudiologia nas redações. "As emissoras de televisão, praticamente todas, tem profissionais fonoaudiólogos para acompanhar o início, o meio e o fim dos profissionais", comentou Gomide (2007). Outra novidade positiva para o telejornalista, destacou Gomide, foi a consultoria de moda para o figurino e maquiagem, que contribuiu para a melhoria da imagem dos profissionais.

Para Pelosi, toda essa evolução tecnológica, ocorrida dos anos 80 até os dias de hoje, transformou a produção de telejornais em uma linha de produção:

se comparar com a linha de montagem de uma indústria, ainda não se tem robôs, mas a mudança do perfil do jornalista se aproxima de um autômato. Tem muito mais tarefa a fazer, no mesmo, ou em tempo mais curto. A remuneração também mudou pra pior. Hoje, o salário médio é 50 por cento inferior ao da década de 80 (PELOSI, 2008).

Um dos avanços tecnológicos que possibilitou melhorias no trabalho do telejornalista, de acordo com Prado, foi a utilização da micro-câmera,

a micro-câmera possibilitou esse jornalismo investigativo, de uma forma muito diferente para televisão, porque você consegue uma imagem que antes você não conseguia. Claro que se tem a questão de até onde você pode avançar na privacidade e uma série de outros fatores (PRADO, 2006). 


\section{CONCLUSÃO}

Ao chegar ao término desta pesquisa, num primeiro momento, é possível verificar que a busca pela análise do processo histórico conduziu-se através de um processo evolutivo contínuo, ininterrupto, intelectual e tecnológico do telejornalismo brasileiro contemporâneo. Durante a pesquisa, foi possível realizar um mergulho profundo nas entranhas do telejornalismo brasileiro, através de seu personagem principal, que é o telejornalista e, ainda, responder a vários questionamentos relativos ao verdadeiro significado desta profissão e de sua importância dentro da comunicação, como um campo representativo e significativo.

Uma ampla revisão e uma reflexão crítica do telejornalismo, nos mais de 58 anos da história da tevê no Brasil, foi realizada, contando com a participação efetiva de uma amostra significativa de 37 profissionais, que vivenciaram este processo, e que puderam relatar suas experiências profissionais. $\mathrm{O}$ aspecto mais valorizado durante o trabalho foi a experiência e não constatar uma verdade absoluta. Essa revisão contou com a fase de transição atual, pela qual a televisão brasileira passa, com o processo de implantação da tevê digital, onde o perfil profissional está voltado para domínio da tecnologia e pela múltipla possibilidade funcional do profissional ingressante no telejornalismo.

Um grande mapa profissional pôde ser construído, através das trajetórias de formação do telejornalista brasileiro, mostrando como se deu, num primeiro momento, a improvisação do radialista na televisão. Depois, com o tempo e com a formação acadêmica, o treinamento e a própria prática cotidiana, conduziu a profissionalização e à efetivação de um padrão. $O$ processo de transformação passou pela falta de credibilidade, durante a ditadura militar, que vigorou por mais de 20 anos no país. O telejornalismo funcionou como uma espécie de porta-voz da ditadura, devido à sua abrangência e penetração, como veículo de comunicação de massa e a já estar presente em todo território nacional. Com 0 processo de redemocratização do país, o telejornalista brasileiro, foi obrigado a reaprender a viver sem as barreiras da censura, mas com o fantasma da autocensura, que demorou um bom tempo para ser banido das redações. 
É difícil precisar se o telejornalismo brasileiro realmente importou o modelo americano, se copiou ou desenvolveu o seu próprio modus operandi, a partir da adequação deste último à cultura brasileira. Prefiro acreditar nesta terceira hipótese, visto que, durante a realização desta pesquisa, ao dialogar com telejornalistas das diversas épocas, culturas, funções e visões, pude, a partir do relato e das contribuições deles, observar que o brasileiro sempre consegue colocar, em tudo o que faz, mesmo que copiado, algo novo, algo local e que demonstre a sua personalidade própria e diferente de tudo o que existe. E no telejornalismo, isso não foi diferente, pois mesmo com toda a influência americana, o resultado final acabou mostrando características totalmente diferentes e únicas ao mundo todo.

Um dos motivos que podem ajudar a sustentar essa constatação é a própria origem do telejornalismo brasileiro e dos profissionais que vieram compor essa nova mídia nos anos 50 - o radiojornalista, pois todos os primeiros profissionais que trabalharam em televisão vinham do rádio: locutor, redator etc. Só saíram de uma sala, onde utilizavam um microfone, para se comunicar e passaram para outra sala, onde, além do microfone, havia um estúdio de televisão, com câmera. Esse primeiro telejornalista já tinha o domínio do rádio e o dom da improvisação, provenientes da experiência anterior.

No caso brasileiro, no final dos anos 50 e início dos anos 60, por falta de recurso técnico, ou seja, por falta de dinheiro, a televisão brasileira importou para o telejornalismo um modelo que não é bem americano, mais parecido com um talk show. Haviam poucas informações, que podiam ser do dia ou da véspera, e meia dúzia de comentaristas, que ficavam falando sobre aquele acontecimento ou sobre aquilo que foi publicado nos jornais. Muito parecido com o que era feito nos Estados Unidos, só que com um toque brasileiro.

Depois, no final da década de 60, em 1969, o governo americano convidou alguns jornalistas, que eram responsáveis por redações no Brasil, para conhecerem o processo de produção dos telejornais americanos. Entre os jornalistas que viajaram, estavam Walter Sampaio, Alice-Maria e Armando Nogueira. Quando voltou, Alice-Maria, junto com Armando Nogueira, implantou o que nós conhecemos, até hoje, como o Jornal Nacional. De acordo com eles, não foi possível executar tudo o que lá foi visto mas, aos poucos, puderam 
melhorar a qualidade do telejornal brasileiro. Alguns fatores, como as limitações técnicas, impediram a reprodução total do modelo americano.

Evidentemente, que no Brasil, incorporou-se muito do telejornalismo norte-americano, mas também, foi colocada uma vertente brasileira nesse processo. Exemplo disso é a reportagem de rua investigativa, que é quase inexistente em telejornais americanos e aqui no Brasil, ainda existe.

É claro que o acordo da Rede Globo com o grupo Time-Life é tido como historicamente importante, pois adiantou uma etapa no desenvolvimento da televisão brasileira. Para alguns dos entrevistados, o fato chega a ser até irrelevante, porque não se chega onde chegou a Rede Globo, sem os recursos que investiu para isso. Porquê se perder tempo demais inventando uma nova tecnologia, correndo-se o risco de chegar no ponto de aplicá-la, e a mesma já estar ultrapassada? A Globo, como outros setores empresariais teve a sabedoria de, ao invés de inventar a roda, comprá-la.

A reportagem de rua brasileira é única no mundo, pois temos aqui repórteres autorais, como Caco Barcellos, José Hamilton Ribeiro, José Carlos Azenha, entre outros, que conseguem dar conta de todo o processo informativo, com criatividade, qualidade de apuração e senso crítico.

Quanto ao modelo americano ter sido implantado no Brasil, isso pode ter ocorrido num primeiro momento, pois foi um formato que, realmente, se mostrou bom de apresentação. Com a evolução, porém, o apresentador deixou de ser um ator da notícia para se tornar um profissional que, realmente, vive na redação - o âncora. Esse modelo serve de padrão, hoje, para o mundo inteiro.

Os anos 70 foram significativos, pois refletiram, muito intensamente, 0 momento político vivido pelo Brasil, através da censura imposta aos telejornalistas. A televisão, por ser uma concessão pública, foi tratada pelos militares como um instrumento de alienação da população.

Alguns aspectos metodológicos propostos para esse trabalho foram mais expressivos, como a entrevista em profundidade, o método etnográfico, a história oral, entre outros, pois se mostraram mais eficientes aos propósitos desejados. Outros, como a pesquisa documental e os arquivos de imagens das emissoras, ficaram relegados a um segundo plano, pois apresentaram dificuldades operacionais, barreiras institucionais e alto custo. A consulta aos 
sites da emissoras forneceu informações, que foram analisadas, checadas e questionadas, devido à origem da fonte.

Contudo, foi possível complementar algumas lacunas existentes, a respeito da formação do telejornalista brasileiro, com vozes anônimas dentro do processo, mas que revelaram, efetivamente, como se conduziu o que se conhece hoje, no Brasil, como telejornalismo.

A maior amostra constituíu-se de profissionais que iniciaram suas carreiras, nos anos 80. Ao todo, 18 profissionais deste período foram entrevistados. Este fato não foi intencional, pois estes profissionais foram encontrados com mais facilidade. Muitos ainda estão no mercado de trabalho, e, à medida que um era entrevistado, logo indicava outro para a pesquisadora.

Este período foi de grande relevância, dentro do processo, devido ao momento político de redemocratização vivido pelo país, ao surgimento de novas redes de televisão e, também, ao processo de regionalização do telejornalismo, entre outros fatores. O período também contou com a efetivação da profissionalização, graças à chegada dos jornalistas oriundos do impresso. A profissão conseguiu romper a barreira da improvisação, que vinha ocorrendo nas décadas anteriores. Também nesta época, foram incorporados ao telejornalismo, elementos como a vídeoreportagem e a reportagem investigativa, dentre outros.

Nos anos 90 a disputa pela audiência tornou-se mais acirrada, devido à chegade das tevês a cabo e UHF, e, também, pelo investimentos que algumas emissoras abertas realizaram no telejornalismo.

A pesquisa mostrou o processo de regulamentação da profissão, no início dos tempos, a fase da desregulamentação, ocorrida no novo milênio, e a indefinição atual dos rumos da profissão de jornalista.

Outro fato observado durante o trabalho, foi o fluxo de informação, que nos anos 50, 60 e 70 era oriundo do jornal e do rádio. Somente nos anos 80, a televisão conseguiu invertê-lo e chegar primeiro aos fatos.

Em relação ao sexo dos entrevistados, a maioria foi de homens (32), ou seja, $86 \%$ do universo da pesquisa, e uma pequena parcela (5) foi de mulheres, com 14\%. Como não houve nenhuma preferência ou escolha, este indicador aponta que a profissão de telejornalista, ao longo do processo analisado, foi exercida, em sua maioria, pelos homens. Fato esse que não 
reflete a condição atual e talvez futura da profissão, que aponta para uma perspectiva de crescimento do número de mulheres.

Ao longo do trabalho, foi possível relacionar uma série de exigências que serão necessárias ao telejornalista na nova fase que está em curso - a televisão digital. O novo profissional deverá ter um conhecimento tecnológico muito mais aprofundado, ou, como alguns profissionais observaram, atuar como um multimídia, com capacidade para escrever, reportar, editar e interagir em tempo real. Este novo profissional, estará próximo de um autômato, com muito mais tarefas para executar, em tempo mais curto.

Como anexo deste trabalho, não foi possível disponibilizar as entrevistas com os 37 telejornalistas, na íntegra, porque ocuparia muito espaço. Elaborei um glossário, conforme sugestão da banca de qualificação, com os termos mais utilizados em telejornalismo e alguns novos, que estão sendo incorporados devido ao processo de transição para a tevê digital, além de outros que estão em processo de transformação. 


\section{REFERÊNCIAS}

\section{Comunicação}

ANDRADE, João Batista de. O povo fala - uma cineasta na área de jornalismo da TV brasileira. São Paulo: Senac, 2002.

ARONCHI DE SOUZA, José Carlos. Gêneros e Formatos na Televisão Brasileira. São Paulo: Summus, 2004.

BAIO, César e OLIVEIRA, Marcelo Pires de. Interatividade e Convergência das Mídias. Apud ROSNAY, Joel de. A revolução das comunicações e seu impacto no homem e na empresa. Conferência pronunciada no Instituto Francês, Madri.

BELTRÃO, Luiz. Subsídios para uma teoria da comunicação de massa. São Paulo: Summus, 1997.

BESPALHOK, Flávia Lúcia Bazan. A prática da reportagem radiofônica na emissora Continental do Rio de Janeiro. Dissertação de Mestrado; UNESP Bauru: 2006.

CANNITO, Newton. Michael Moore e os potenciais do documentário sociológico. In: Sinopse -revista de cinema, no10 ano VI; dezembro 2004; páginas 31 a 33 .

HELZ, Daniel. A história secreta da Rede Globo. Porto Alegre - RS, Editora Tchê! 1987.

IANNI, Octavio. O Príncipe Eletrônico.

http://bibliotecavirtual.clacso.org.ar/ar/libros/anpocs/ianni.rtf (acesso em 14/04/2006). 
JOLY, Ana Vitória. A Interatividade na Televisão Digital - Um Estudo Preliminar. http://bocc.ubi.pt/pag/joly-ana-interatividade-tv-digital-port.html . Universidade Federal de São Carlos (Acesso em 12 de dezembro de 2005).

LIMA, Fernando Barbosa Lima. Nossas câmeras são seus olhos. Rio de Janeiro: Ediouro, 2007.

MARQUES DE MELO José. Teoria da Comunicação: Paradigmas LatinoAmericanos. Petrópolis - RJ: Vozes, 1998.

. Jornalismo Brasileiro. Porto Alegre: R Sulina, 2003.

. Imprensa Brasileira - personagens que fizeram

história. São Paulo: Imprensa Oficial, 2005.

MORAIS, Fernando. Chatô - o rei do Brasil. São Paulo: Cia. das Letras, 1994.

MURRAY, Janet $\mathrm{H}$. Hamlet on the Holodeck: the future of narrative in cyberspace. New York: The Free Press, 1997.

POPPER, Karl e CONDRY, John. Televisão: um perigo para a democracia. Lisboa: Gradiva, 1999.

WATTS, Harris. On Câmera - o curso de produção de filme e vídeo da BBC. São Paulo: Summus, 1984.

\section{História Oral}

MEIHY, José Carlos Sebe Bom. Manual de História Oral. São Paulo: Edições Loyola, 2005. 
FREITAS, Sônia Maria de. História Oral: procedimentos e possibilidades. São Paulo: e-book, 2006.

\section{Jornalismo}

ANDRADE, Sérgio Murilo. O ensino, a formação específica e a valorização da profissão de jornalista no Brasil. Disponível em: http://www.fenaj.org.br/arquivos/artigosergiomurilloportugues.doc - Acesso em 04 de agosto de 2008)

BOTÃO, Paulo Roberto; CARVALHO, Juliano; CORDENANSSI, Ana Maria, NEGRÃO, João José de Oliveira; VALVERDE, Franklin. Avaliação dos cursos de graduação e $\quad 0$ ensino de jornalismo. http://www.fnpj.org.br/downloads/relatorio-avaliaca0\%5B2006\%5D.pdf (Acesso em 01 de agosto de 2008).

FORTES, Rafael; ALBUQUERQUE, Afonso de. $O$ jornalismo e a obrigatoriedade do diploma: negociando as fronteiras da comunidade $\begin{array}{lllll}\text { jornalística no } & \text { Brasil. } & \text { Disponível }\end{array}$ http://revcom2.portcom.intercom.org.br/index.php/cs um/article/view/4761/4475 (Acesso em 02 de agosto de 2008).

KOSHIYAMA, Alice Mitika. A prática política para se jornalista Eca/Usp 19751976. Disponível em: http://www.eca.usp.br/pjbr/arquivos/23k03.PDF.pdf (Acesso em 02 de agosto de 2008)

MEDITSCH, Eduardo. Ciespal trouxe progresso... e o problema quase insolúvel do comunicólogo. Artigo apresentado no III Ciclo de Estudos sobre a Escola Latinoamericana de Comunicação, São Bernardo do Campo, 1999.

MENDES, Ricardo Fontes. A profissionalização do jornalismo no Brasil. 1999. Disponível em http://www.saladeprensa.org/art40.htm. (Acesso em 01 de agosto de 2008). 
NUNES, Antonio Carlos Felix. Fora de pauta (Histórias e História do Jornalismo no Brasil). São Paulo: Proposta Editorial, 1981.

PINHO, José Benedito. Trajetória e Demandas do Ensino de Graduação em Publicidade e Propaganda no Brasil. Disponível em: http://www.eca.usp.br/alaic/Livro\%20GTP/trajetoria.htm. (Acesso em 01 de agosto de 2008).

\section{Televisão Telejornalismo}

BECKER, Beatriz, A linguagem do Telejornal - Um estudo da cobertura dos 500 anos do descobrimento do Brasil. Rio de Janeiro: E-papers, 2005.

BONARITA, Maria Elvira. História e comunicação - rádio e TV no Brasil. Rio de Janeiro: Vozes, 1982.

BORELLI, Silvia H. Simões e PRIOLLI, Gabriel (coords). A Deusa Ferida: por que a Rede Globo não é mais a campeã absoluta de audiência. São Paulo: Summus, 2000.

BOURDIEU, P. Sobre a Televisão. Rio de Janeiro: Jorge Zahar Editor, 1997.

BRASIL, Antônio. A revolução das imagens - uma proposta para o Telejornalismo na Era Digital. Rio de Janeiro: Ciência Moderna, 2005.

CAPPARELLI, Sérgio, LIMA, Venício A. de. Comunicação e Televisão desafios da pós-globalização. São Paulo: Hacker, 2004.

COUTINHO, Iluska. Telejornalismo no Brasil: um olhar sobre os reflexos do padrão americano.

http://www.intercom.org.br/papers/nacionais/2005/resumos/R0647-2.pdf acesso em 30 de junho de 2008. 
FILHO, Daniel. O circo eletrônico. Fazendo TV no Brasil. Rio de Janeiro: 2001 Jorge Zahar Editor 2001.

JUNIOR, Gonçalo. O país da TV. São Paulo: Conrad, 2001.

LEAL FILHO, Laurindo, A melhor TV do mundo - o modelo Britânico de televisão. São Paulo: Summus, 1997.

LORÊDO, João. Era uma Vez a Televisão. São Paulo: Alegro, 2000.

MACHADO, Romério Costa. Afundação Roberto Marinho. São Paulo: Meus Caros Amigos, 1993.

MATTOS, Sérgio. A televisão no Brasil: 50 anos de história. Salvador: Vozes, 2000.

. História da televisão Brasileira - uma visão econômica, social e política. Petrópolis - RJ: Vozes, 2002.

MELLO E SOUZA, Cláudio. 15 anos de História. Rio de Janeiro: Rio Gráfica, 1984.

MEMÓRIA O GLOBO. Jornal Nacional: A notícia faz história. Rio de Janeiro: Jorge Zahar Editor, 2004.

PATERNOSTRO, Vera Íris. O texto na TV - Manual de Telejornalismo. Rio de Janeiro: Campus, 1999.

PEREIRA JR. Alfredo Eurico Vizeu Pereira. Decidindo o que é notícia - os bastidores do telejornalismo. Porto Alegre: Edipurs, 2003.

. O lado oculto do telejornalismo. Florianópolis:

Calandra, 2005. 
PUCCININ, Fabiana. Notícias na TV Global: Diferenças (ou não) entre o telejornalismo americano e europeu. www.bocc.ubi.pt/pag/puccinin-fabianatelejornalismo-americano-europeu.pdf -acesso em 17 de fevereiro de 2008.

REZENDE, Guilherme Jorge. Telejornalismo no Brasil - um perfil editorial. São Paulo: Summus, 2000.

RIXA, Almanaque da TV - 50 anos de memória e informação. São Paulo: Objetiva, 2000.

SACRAMENTO. Igor Pinto. Depois da revolução, a televisão - cineastas de esquerda no jornalismo televisivo dos anos 70. Dissertação de mestrado ECO/ UFRJ, 2008.

SAMPAIO, Mario Ferraz. História do Rádio e da TV no Brasil e no mundo. Rio de Janeiro: Achiamé, 1984.

SAMPAIO, Walter. Jornalismo Audiovisual - rádio, TV e cinema. Petrópolis RJ: Vozes, 1971.

SILVA, Carlos Eduardo Lins da. Muito além do Jardim Botânico. São Paulo: Summus, 1985.

SQUIRRA, Sebastião Carlos de M. Boris Casoy - o âncora no telejornalismo brasileiro. São Paulo: Vozes, 1993.

SQUIRRA, Sebastião Carlos de M. Aprender Telejornalismo - produção e técnica. São Paulo: Editora Brasiliense, 2004.

SOUZA, Cláudio Mello e. 15 anos de História. Rio de Janeiro: Rio Gráfica, 1984.

TEMER, Ana Carolina Pessôa Temer. Notícias \& Serviços nos telejornais da Rede Globo. Rio de Janeiro: Sotese, 2002. 
. Colhendo notícias, plantando imagens: a reconstrução da história da TV Triângulo a partir da memória dos agentes do seu telejornalismo. 1998, 327 p. Mestrado - Comunicação Social, São Bernardo do Campo Universidade Metodista.

THOMAZ, Patrícia. A linguagem experimental da videoreportagem. http://revcom.portcom.intercom.org.br/index.php/inovacom/article/view/1535/13 56. (acesso em 18 de maio de 2008)

TAVOLARO, Douglas. O Bispo - a história revelada de Edir Macedo. São Paulo: Larousse, 2007.

VÁRIOS AUTORES. TV aos 50 - Criticando a Televisão Brasileira do Seu Cinqüentenário. São Paulo: Fundação Perseu Abramo, 2000.

VÁRIOS AUTORES. A Deusa Ferida. São Paulo: Summus, 2000.

VASQUES, Rúbia de Oliveira. O conhecimento brasileiro sobre telejornalismo Estudo comparativo dos manuais didáticos mais usados nos cursos de jornalismo. Dissertação de Mestrado; Universidade Metodista de São Paulo, São Bernardo do Campo, 1999.

XAVIER, Ricardo. Almanaque da TV - 50 anos de memória e Informação. São Paulo: Objetiva, 2000.

\section{Metodologia da Pesquisa}

DUARTE, Jorge e BARROS, Antonio - organizadores. Métodos e Técnicas de Pesquisa em Comunicação. São Paulo: Editora Atlas, 2005.

ECO, Umberto. Como se faz uma tese. São Paulo: Perspectiva, 1995. 
LOPES, Maria Immacolata Vassalo de. Pesquisa em Comunicação Formulação de um modelo metodológico. São Paulo: Loyola, 1994.

THIOLLENT, Michel J. M. Crítica metodológica, investigação social \& enquête operária. Polis, 1980.

\section{Variados}

MERTON, Robert K. Sociologia - Teoria e Estrutura. São Paulo: Mestre J, 1970.

MORAES, Denis. A hegemonia das corporações de mídia no capitalismo global. 2000. http://www.acessa.com/gramsci/?page=visualizar\&id=297 acesso em 30 de junho de 2008.

ZUFFO, Marcelo Knöricho. TV digital aberta no Brasil - políticas estruturais para um modelo nacional.

\section{Sites}

http://www.tvcultura.com.br - acesso em 12 de novembro de 2006.

http://www.goodnightandgoodluck.com - acesso em 12 de novembro de 2006.

http://www.alltv.com.br -acesso em 01 de março de 2006.

http://www.webinsider.oul.com.br - acesso em 01 de março de 2006. http://www.wikipedia.org.br - acesso em 02 de março de 2006. http://www.bocc.ubi - acesso em 12 de dezembro de 2005.

http://www.dotlink.com.br/t tecnologia.htm - acesso em 25 de fevereiro de 2006.

http://www.iar.unicamp.br/disciplinas - acesso em 25de fevereiro de 2006. 
http://televisionado.wordpress.com/2008/05/08/como-nasceu-o-indiozinho-datupi/ - acesso em 12 de maio de 2008.

http://pt.wikipedia.org/wiki/Programa de Domingo - acesso em 25 de maio de 2008.

http://pt.wikipedia.org/wiki/Documento Especial - acesso em 25 de maio de 2008.

http://www.redemanchete.net/ - acesso em 25 de maio de 2008.

http://www.fazendomedia.com/globo40/romero7.htm - acesso em 17 de outubro de 2008.

http://www.fnpj.org.br/downloads/relatorio-avaliacao[2006].pdf - acesso em 02 de agosto de 2008.

http://pt.wikipedia.org/wiki/Globo News - acesso em 25 de maio de 2008.

http://pt.wikipedia.org/wiki/Band News - acesso em 25 de maio de 2008.

www.geocities.yahoo.com.br/interatividade.htm - acesso em 30 de março de 2006.

http://video.globo.com/Videos/Player/Noticias/.html- acesso em 30 de agosto de 2008.

http://veja.abril.com.br/251198/p 182.html - acesso em 07 de julho de 2008.

http://www.fnpj.org.br/downloads/relatorio-avaliacao[2006].pdf - acesso em 01 de agosto de 2008.

http://www.fenaj.org.br/arquivos/artigosergiomurilloportugues.doc - acesso em 17 de outubro de 2008.

\section{Vídeos}


GLOBO, Rede - Globo Repórter - 50 anos da TV exibição em 2000.

Good Night, and Good Luck. Gênero: Drama, Duração: 93 minutos,Ano de Lançamento (EUA): 2005. Estúdio: Warner Independent Pictures / 2929 Productions / Redbus Pictures / Section Eight Ltd. / Metropolitan / Participant Productions / Davis-Films / Tohokashinsha Film Company Ltd.Distribuição: Warner Bros.Direção: George Clooney Roteiro: George Clooney, baseado em roteiro de Grant Heslov; Produção: Grant Heslov; Fotografia: Robert Elswit; Desenho de Produção: James D. Bissell; Direção de Arte: Christa Munro; Figurino: Louise Frogley;Edição: Stephen Mirrione 


\section{ANEXOS}




\section{Entrevistas Gravadas:}

AMORIN, Carmen. Entrevista gravada em São Paulo em 03 de setembro de 2007.

ANDRADE, João Batista de. Entrevista gravada em São Paulo em 12 de dezembro de 2006.

ARONCHI DE SOUZA, José Carlos. Entrevista gravada em Natal em...

AZENHA, Luiz Carlos. Entrevista gravada em 31 de novembro de 2006.

BACIC, Gregório. Entrevista gravada em São Paulo no dia 21 de setembro de 2005.

BARCELLOS, Caco. Entrevista gravada em Fortaleza em 20 de maio de 2008.

CARDIM, Clélia. Entrevista gravada em São Paulo em 26 de julho de 2006.

COSTA, Demétrio. Entrevista gravada em São Paulo no dia 08 de novembro de 2006.

DO PRADO, Edson Higo. Entrevista gravada em São Paulo no dia 10 de outubro de 2006.

DALEVO JÚNIOR. Amilcare. Entrevista gravada em São Paulo no dia 09 de novembro de 2006.

COUTINHO, Eduardo. Entrevista gravada no Rio de Janeiro em 16 de junho de 2008.

FANUCCHI, Mario. Entrevista gravada em São Paulo no dia 26 de outubro de 2006.

GONZALEZ, Luiz Zinger. Entrevista gravada em São Paulo em 29 de novembro de 2006. 
GOMIDE, João Marcos. Entrevista gravada em Fortaleza em 16 de março de 2007.

HOINEFF, Nelson. Entrevista gravada no Rio de Janeiro em 20 de novembro de 2006.

JORDÃO, Fernando Pacheco. Entrevista gravada em São Paulo no dia 31 de julho de 2006.

KALIL, Vanessa. Entrevista gravada em São Paulo em 14 de novembro de 2006.

LEAL FILHO, Laurindo. Entrevista gravada em São Paulo em 30 de maio de 2007.

LEANDRO, Paulo Roberto Lobo. Entrevista gravada em São Paulo no dia 09 de novembro de 2006.

LIMA, Fernando Barbosa. Entrevista gravada no Rio de janeiro em 20 de novembro de 2006.

LUCHETTE NETO, Alberto. Entrevista gravada em São Paulo no dia 29 de março de 2006.

MALAVOLTA, Luiz Antonio. Entrevista gravada em São Paulo no dia 26 de julho de 2006.

MARKUN, Paulo. Entrevista gravada em Fortaleza em 25 de maio de 2007.

MERCADANTE, Luiz Fernando. Entrevista gravada em São Paulo no dia 24 de outubro de 2006.

NADER, Alceu. Entrevista gravada em São Paulo no dia 18 de abril de 2008.

NASCIMENTO, Marco Antonio Camargo. Entrevista gravada em São Paulo em 07 de novembro de 2006. 
PASSARINHO, Sandra. Entrevista gravada no Rio de Janeiro em 20 de novembro de 2006.

PELOSI, Celso. Entrevista realizada via internet em 6 de fevereiro de 2008.

PEREIRA JÚNIOR, Alfredo Eurico Vizeu. Entrevista gravada em Brasília no dia 9 de setembro de 2006.

PERES, Fábbio. Entrevista gravada em 12 de dezembro de 2006.

POPPOVIC, Silvia. Entrevista gravada em São Paulo em 12 de dezembro de 2006.

RODRIGUES, Jacqueline Matoso. Entrevista gravada em São Paulo em 02 de setembro de 2007.

SANTANA, José Maria Santana. Entrevista gravada em São Paulo no dia 01 de novembro de 2006.

SOARES, Amauri Sérgio. Entrevista gravada no Rio de Janeiro em 16 de junho de 2008.

SQUIRRA, Sebastião Carlos de M. Entrevista gravada em São Bernardo do Campo em 31 de maio de 2007.

VIZEU, Carlos Alberto Ballut. Entrevista gravada no Rio de janeiro em 16 de maio de 2008.

VIANNA, Rodrigo Luiz Brito. Entrevista gravada em São Paulo em 21 de dezembro de 2006. 


\section{GLOSSÁRIO}

AFILIADAS - Emissoras de TV que retransmitem a programação da emissora principal de uma rede de emissoras. Elas têm normas estabelecidas e seguem a programação original, mas podem, normalmente, produzir programação própria.

ALCANCE - a TV é um veículo abrangente e de grande alcance. Ela não distingue classe social ou econômica, atinge a todos. O jornalismo na TV tem, portanto que considerar como vai tratar uma notícia, já que ela pode ser "vista" e "ouvida" de várias maneiras diferentes.

ANALÓGICO - Sistema eletrônico de mostrar a informação/imagem. Sistema oposto ao digital. Utiliza pontos de semelhança entre coisas diferentes. Podemos descrever um fenômeno elétrico e um mecânico de maneira idêntica, através da matemática.

ANCHORMAN OU ÂNCORA - Apresentador do telejornal que interpreta as notícias com base em conhecimento próprio; mediador. O anchorman "amarra" o programa. Anchorwoman: apresentadora.

AO VIVO - Transmissão de um acontecimento no exato momento em que ele ocorre. Pode ser externa ou do próprio estúdio da emissora. Costuma-se chamar de link o ao vivo.

ARTE - llustração gráfica, computadorizada, inserida na reportagem para facilitar a compreensão e assimilação de uma informação. São muito usadas para localizar locais (mapas), e podem ser animados ou não. Atualmente a arte é produzida, em alguns casos, até em 3D.

ATSC-T -Advanced Television Systems Committee. Padrão Norte Americano de tevê digital. Contempla a digitalização voltada à alta definição resolução HDTV, ainda não contempla recursos relacionados com a mobilidade e portabilidade. 
AVID - Um sistema de edição não-linear que trata imagens, sons, caracteres gráficos, da mesma maneira que os processadores de texto como o Word: de maneira rápida e eficiente, onde as correções e o esquema "copy-paste" estão ao seu lado.

BETA - Formato magnético de videotape, que inclui desde a câmera até o próprio VT de edição.

CHROMA-KEY - é uma chave de cor. Trata-se da possibilidade técnica que permite eliminar as informações visuais contidas num cenário em uma das cores básicas, normalmente o azul. Com isto, é possível fazer fusão apenas das partes da imagem que nos interessam, superpondo-as a outra imagem gerada por outra câmera. Está sendo substituído pelo Newsmatte, que apresenta melhores definições e potencialidades de uso.

CORTE - Mudança de uma imagem para outra, mudança de cena.

CORRESPONDENTE - Jornalista que faz cobertura de uma determinada cidade do Brasil ou no exterior, e envia reportagens com regularidade para os telejornais da emissora.

COZINHASR - Reescrever o texto jornalístico, alterando-o ou resumindo-o.

COORDENADOR DE PRODUÇÃO - Jornalista que coordena todo o trabalho dos produtores e organiza o trabalho dos repórteres. Substitui o antigo chefe de reportagem.

CRÉDITO - Identificação (o nome) de repórteres, entrevistados, cidades, estados ou país. É usado também para a relação de nomes dos profissionais que trabalham no telejornal e que aparece no final.

$D E A D L I N E$ - Prazo final para o repórter retornar à emissora com uma reportagem a tempo de entrar no ar. É usado também no prazo de fechamento do telejornal: prazo final de entrega das matérias prontas para o jornal ir ao ar. $\mathrm{O}$ deadline permite ao editor-chefe ter segurança do que ele tem em mãos minutos antes do jornal ir ao ar. 
DECUPAR A FITA - Assistir à fita gravada na rua pela equipe de reportagem e marcar em um papel a minutagem, isto é, em quais minutos da fita estão as melhores cenas, as entrevistas, as passagens do repórter etc. atualmente usase o time code. Essa "decupagem" vai servir para o editor localizar com mais facilidade e rapidez as imagens e sons que ele deseja, na hora de editar.

DIGITAL - Oposto ao analógico. Sistema que utiliza a forma binária (diz-se aquela que usa combinação dos números binários 1 e 0 alternadamente, de modo a manipular informações sem perda de qualidade da mesma).

DIRETOR DE TV - É o responsável pelo comando da mesa de cortes e pelo andamento do programa, de acordo com o script. É o elemento que mantém contato permanente com os cameramen, o diretor de estúdio, a sonoplastia e o videocassete. Todos trabalham sob a coordenação do diretor de TV.

DVB - Digital Vídeo Broadcasting - Padrão europeu de tevê digital. Contempla peculiaridades específicas de cada país. Por exemplo, televisores DVB-T na Inglaterra não funcionam na Espanha e vice-versa. Incorpora alguns recursos de mobilidade.

EDIÇÃO - Montagem de áudio e vídeo de uma reportagem.. produto final, o que vai ao ar.

EDITOR-CHEFE - Jornalista responsável pelo telejornal. Atualmente vem se padronizando que editor-chefe também apresenta o telejornal como âncora.

EDITOR-EXECUTIVO - Com o acúmulo de funções do editor-chefe também como apresentador (âncora), o editor-exectuivo é o responsável por toda logística do telejornal a partir do momento que o chefe vai para o estúdio apresentar o telejornal.

EDITOR DE IMAGENS - Técnico que monta as imagens da reportagem seguindo roteiro prévio estabelecido com o editor de texto.

EDITOR DE TEXTO - Jornalista que elabora a edição final de uma matéria, responsável pelo texto e imagem. 
EDITORIA DE ARTE - Departamento da emissora que se responsabiliza pelas artes - ilustrações, gráficos, selos, mapas do telejornais.

ENVOLVIMENTO - a TV exerce fascínio sobre o telespectador, pois consegue transportá-lo para "dentro" de suas histórias. Não existe um padrão de linguagem televisiva, mas há no telejornalismo a forma pessoal de "contar" notícia e a familiaridade com repórteres e apresentadores, que seduzem e atraem telespectadores. Trabalho encomendado a um profissional sem vínculo empregatício.

ESCALADA - Frases de impacto sobre os assuntos do telejornal que abrem o programa. O mesmo que manchetes. Uma escalada bem elaborada deve prender a atenção do telespectador, do começo ao fim do telejornal. Frases curtas, podem ou não ter teasers: dois ou três takes ( 5 a 7 segundos) das imagens principais.

ESPELHO - É a relação e a ordem de entrada das matérias no telejornal, sua divisão por blocos, a previsão dos comerciais, chamadas e encerramento. Como a própria palavra indica, reflete o telejornal. É feito pelo editor-chefe, e todas as pessoas envolvidas na operação do programa recebem uma cópia do espelho. As matérias colocadas no espelho são identificadas por retrancas.

FADE-IN - O clareamento gradual do vídeo, que, a partir da inexistência de sinal, apresenta imagem na tela.

FADE-OUT - o escurecimento gradual do vídeo até o preto total.

FRAME - A menor parte de uma imagem em vídeo-teipe. $\mathrm{O}$ equivalente ao quadro ou fotograma do filme.

FREE-LANCE - Trabalho encomendado a um profissional sem vínculo empregatício.

GC - GERADOR DE CARACTERES - Equipamento eletrônico que permite inserir no vídeo caracteres em forma de letras, números e outros sinais gráficos. 
HARD NEWS - Se refere a uma notícia quente, séria, importante. É o contrário de soft news.

HDTV - High-Definition Television - é um sistema de transmissão televisiva com uma resolução de tela significativamente superior à dos formatos tradicionais (NTSC, SECAM e PAL). É o sistema de tevê digital adotado pelo Brasil.

ILHA DE EDIÇÃO LINEAR - Conjunto de equipamentos de vídeo que funciona de forma integrada para gravar, reproduzir ou editar uma notícia ou programa de televisão. Também conhecida como ilha de VT.

ILHA DE EDIÇÃO NÃO-LINEAR - Ilha de edição no computador, que converte imagens para um formato digital e pode ser modificado livremente. Normalmente as imagens são digitalizadas no formato $A V I$, que foi desenvolvido pelo Microsoft. Estas ilhas podem editar em PC ou MAC. No Brasil os mais usados são; Final Cut Pro, Adobe Premiere, Avid e Sony Vegas, entre outros.

IMEDIATISMO - transmite informação contemporânea quando mostra o fato no momento exato em que ele ocorre através da imagem - o signo mais acessível à compreensão humana. A TV tem hoje uma agilidade muito grande, porque o aparato técnico para uma transmissão está muito simplificado. Pequenas emissoras já possuem unidades móveis de jornalismo para reportagens "ao vivo" que são instaladas com rapidez e velocidade. Os satélites mostram fatos do outro lado do mundo.

ÍNDICE DE AUDIÊNCIA - a medição do interesse do telespectador orienta a programação e cria condições de sustentação comercial. $O$ índice de audiência interfere de modo direto, a ponto de a emissora se posicionar dentro de padrões (trilhos) que são os resultados de aceitação por parte do públicotelespectador.

INFORMAÇÃO VISUAL - transmite mensagens através de uma linguagem que independe do conhecimento de um idioma ou da escrita por parte do receptor. 
A TV mostra e o telespectador vê: ele se informa, está recebendo a notícia e ampliando o seu conhecimento.

INSERT - Pode ser de vídeo ou de áudio. Trata-se da inclusão de pequena informação sonora ou visual em matéria já editada. A imagem ou o som são incluídos em ponto definido de entrada e saída, não interferindo no resto da matéria.

INSTANTANEIDADE - a informação de TV requer "hora certa" para ser vista e ouvida - a mensagem é momentânea, instantânea. Ela é "captada" de uma só vez, no exato momento em que é emitida. Não tem como "voltar atrás e ver de novo", ao contrário de jornal ou revista.

ISBD - Integrated System Digital Broadcast - Padrão japonês de tevê digital. Do ponto de vista de tecnologia é o mais avançado porque considera flexibilidade, uma intensa convergência, suporta modulação digital de alta qualidade, mobilidade, portabilidade e alta definição.

LAPADA - Resumo temático (Nota coberta) de várias matérias de diversos locais sobre o mesmo assunto. Pode se também fazer, por exemplo, uma lapada com os principais assuntos internacionais.

LAUDA - Folha específica usada na redação telejornalística.

LINK - Ligação estúdio-transmissor e transmissor-transmissor. Trata-se de serviço técnico que permite o envio de sinal de televisão para transmissão. É também a ligação da emissora com uma unidade geradora de sinal (imagens ao vivo de uma transmissão de futebol, por exemplo).

MANCHETE - Texto conciso que contém uma informação forte. Destina-se a atrair a atenção do telespectador para a notícia que vem a seguir.

MATÉRIA - o que é publicado ou se destina a ser publicado em qualquer veículo de informação. É usado como sinônimo de reportagem.

MOVIOLA - Equipamento usado para a montagem em filme. 
NOTA SIMPLES/NOTA AO VIVO OU NOTA PELADA - Notícia lida pelo apresentador do telejornal sem qualquer imagem de ilustração.

NOTA COBERTA - quando não se tem um repórter, mas existe uma notícia com ilustrações, usa-se a nota coberta, que podem ser ao vivo ou pré-gravada. As notas cobertas são textos noticiosos redigidos pelos editores e gravados pelos apresentadores dos telejornais e que são cobertos por imagens na ilha de edição.

NOTA PÉ - Uma nota simples, lida no final de uma matéria trazendo informação complementar ou que faltou à reportagem.

OFF - Vozes ou sons presentes numa gravação sem o aparecimento da imagem da fonte geradora. Vem de "off de Record", que significa informação fornecida ao repórter cuja fonte não quer ou não pode ser identificada.

OFF-LINE - Em edição de vídeo, uma pré-edição feita numa máquina mais barata, para se experimentar a melhor forma de editar uma produção.

Padrão Chinês - utiliza muito dos conceitos incorporados nos padrões já existentes (ATSC, DVB e ISDB) sendo seu principal foco a possibilidade de convergência com aparelhos celulares.

PASSAGEM - Parte que faz a ligação entre um trecho da reportagem e outro. Serve de "ponte" no caso de reportagens que ocorrem em dois lugares.

PAUTA - Descrição dos assuntos que podem ser produzidos pela reportagem.

PAUTEIRO - Jornalista que organiza a pauta. Atualmente o termo mais empregado é produtor.

PREVIEW - Monitor onde se pode ver a primeira imagem da matéria editada antes dela ir para o ar. Serve para dar segurança à operação.

PRODUÇÃO - Organização e coordenação do trabalho prévio para a reportagem: pesquisa, imagens de arquivo, horários marcados, levantamento de material etc. 
PRODUTOR - Jornalista encarregado de obter e organizar os elementos e informações necessários para a realização de um programa ou de uma reportagem.

RADIOESCUTA - Profissional (ou estagiário de jornalismo) a quem compete levantar assuntos de interesse para o telejornal, a partir da escuta dos programas noticiosos radiofônicos e da televisão.

RELATÓRIO DE REPORTAGEM - Texto do repórter com todas as informações obtidas sobre o acontecimento. Identifica também os entrevistados e resume as imagens gravadas. Deve ser feito todos os dias e entregue à chefia de reportagem.

RETRANCA - Identificação da matéria. Não significa o título da matéria. É pela retranca que a matéria fica identificada em todos os momentos do telejornal, desde a saída para a reportagem, a edição, no espelho e quando vai ao ar. É imprescindível retranca clara, precisa, e deve ser a mesma usada por todos os que trabalham naquela matéria.

SBTV-T - O processo de digitalização no Sistema Brasileiro de TV Digital consiste na digitalização dos canais existentes e também na troca de informações diversas.

SCRIPT - No telejornalismo é o conjunto das laudas redigidas e devidamente marcadas sobre as matérias que irão ao ar.

SONORA - Termo que se usa para designar uma fala da entrevista. Exemplo: cortar uma sonora (escolher uma determinada fala).

STAND-BY - Sinal de atenção, no sentido técnico. No telejornal, é a produção de reportagem objetiva só com a presença do repórter, que apresenta a última versão sobre determinado assunto. Atualmente o termo vem sendo utilizado para designar as matérias que não entraram no telejornal e estão prontas para entrar a qualquer momento. Geralmente elas estão discriminadas no final do espelho do telejornal. 
SUPERFICIALIDADE - o timing, o ritmo da TV proporciona uma natureza superficial às suas mensagens. Os custos das transmissões, os compromissos comerciais e a briga pela audiência impedem o aprofundamento e a análise da notícia no telejornal diário. Há programas específicos de maior densidade jornalística.

STILL - Imagem ou quadro parado, congelado.

SUWTCHER - Local onde está o controle de uma unidade de produção, normalmente composta por: um estúdio, câmeras, telecine, vídeos, geradores de caracteres e sonoplastia. É onde trabalha o diretor de TV.

TAKE - O mesmo que cena.

TAPE - Fita de plástico, revestida por fina camada de óxido de ferro, onde estão gravados, magneticamente, a imagem e o som.

TELEPROMPTER ou TP - aparelho que permite a reprodução do script sobre a câmera, facilitando a leitura do apresentador. Ele não precisa decorar o texto ou baixar os olhos para ler no papel, e portanto olha diretamente para 0 telespectador.

TIME CODE - Relógio digital que conta o tempo com precisão de frames, utilizado para decupagem de fitas e na edição dessas fitas. Marca horas, minutos, segundos e frames do que está gravado: 08:30:55:22.

TV A CABO - Sistema de distribuição de sinais de áudio e vídeo que liga uma central de emissora (emissora) a diversos terminais através de cabos, normalmente utilizando linhas terrestres.

UMATIC - formato magnético de videotape, que inclui desde a câmera até o próprio VT de edição. Usa fita 3/4 de polegada embutida em cassete.

ZOOM-IN - Termo inglês que significa a aproximação da imagem do objeto ou cenário. Substituído por "aproximação de imagem". O movimento pode ser ótico (só com a lente) ou mecânico, com o deslocamento da câmera. 
ZOOM-OUT - Termo inglês que significa o afastamento da imagem do objeto ou cenário. Substituído por "afastamento da imagem". O movimento pode ser ótico (com a lente) ou mecânico com o deslocamento da câmera. 